UNIVERSIDADE DE SÃO PAULO

FACULDADE DE ECONOMIA, ADMINISTRAÇÃO E CONTABILIDADE DEPARTAMENTO DE ADMINISTRAÇÃO PROGRAMA DE PÓS-GRADUAÇÃO EM ADMINISTRAÇÃO

A CONTRIBUIÇÃO DO NEUROMARKETING PARA O ESTUDO DO COMPORTAMENTO DO CONSUMIDOR

Aluna: Cláudia Colaferro

Orientador: Prof. Dr. Edson Crescitelli 
Prof. Dr. João Grandino Rodas

Reitor da Universidade de São Paulo

Prof. Dr. Reinaldo Guerreiro

Diretor da Faculdade de Economia, Administração e Contabilidade

Prof. Dr. Adalberto Américo Fischmann

Chefe do Departamento de Administração

Prof. Dr. Lindolfo Galvão de Albuquerque

Coordenador do Programa de Pós-Graduação em Administração 


\section{CLÁUdIA COLAFERRO}

\section{A CONTRIBUIÇÃO DO NEUROMARKETING PARA O ESTUDO DO COMPORTAMENTO DO CONSUMIDOR}

Dissertação de Mestrado apresentada ao Departamento de Administração de Empresas da Faculdade de Economia, Administração e Contabilidade da Universidade de São Paulo como requisito para obtenção do título de Mestre Administração de Empresas.

Orientador: Prof. Dr. Edson Crescitelli

\section{SÃO PAULO}




\section{FICHA CATALOGRÁFICA}

Elaborada pela Seção de Processamento Técnico do SBD/FEA/USP

Colaferro, Claudia Almeida

A contribuição do neuromarketing para o estudo do comportamento do consumidor / Claudia Almeida Colaferro. - São Paulo, 2011. $172 \mathrm{p}$.

Dissertação (Mestrado) - Universidade de São Paulo, 2011. Orientador: Edson Crescitelli.

1. Comportamento do consumidor 2. Neurociências 3. Pesquisa de mercado 4. Ciência cognitiva I. Universidade de São Paulo.Faculdade de Economia, Administração e Contabilidade. II. Título.

CDD - 658.8342 
Aos meus filhos Carolina e Henrique, e ao Fábio, com muito amor. 
Agradeço à minha família todo o apoio e compreensão pelas horas de estudo nas quais precisei me dedicar.

Agradeço ao Fábio que me apoia e divide comigo a mesma visão de mundo e o caminho escolhido para percorrê-lo.

Agradeço aos meus pais, meus primeiros e incondicionais incentivadores, que por promoverem a minha autoestima, desde os primórdios, me fizeram acreditar que tudo pode ser possível; em especial à minha mãe, um exemplo de que nunca é tarde para conseguir o que se quer em nossa vida.

Agradeço ao meu irmão, Prof. Dr. Renato de Sousa Almeida pelo exemplo acadêmico e apoio em minhas horas de insegurança.

Agradeço aos meus médicos holísticos Dr Luiz Fernando Barros Carvalho e Beatriz Ferraz da Cunha que me fizeram chegar até aqui inteira e continuam me colocando em pé.

Agradeço ao amigo Romeo Busarello pelo incentivo à minha busca inicial pela vida acadêmica.

Agradeço ao meu orientador e Prof. Dr. Edson Crescitelli por ter acreditado em meu potencial e também pelo apoio e força em todas as minhas viagens de pensamento e ajuda na busca do caminho para esta dissertação.

Agradeço ao Prof. Dr. Geraldo Toledo por seu incentivo inicial ao meu processo ao mundo acadêmico, à amplitude de suas aulas, às correções da qualificação e ao término do meu trabalho.

Agradeço à Prof. Dra. Ana Ikeda e Prof. Dr. Marcos Campomar pela leveza do ensino baseado no jogo de empresas.

Agradeço ao Prof. Dr. José Afonso Mazzon pelo exemplo de paixão demonstrado em sua forma de raciocínio.

Agradeço aos professores do ICB, ao Prof. Dr.Luiz Roberto Giogetti de Britto por seu exemplo de como encantar ensinando para um plenário repleto; ao Prof Dr. Luiz Eduardo Ribeiro do Valle por sua abertura a todas as contribuições em debates ricos sobre a neurociência e ao seu apoio ao meu projeto de pesquisa empírica.

Agradeço aos professores da ECA, à Prof. Dra. Rosana Lima Soares por suas reflexões sobre o discurso; à Prof. Dra. Mayra R. Gomes com sua proposta de aula riquíssima em diversos ângulos de reflexão. Ao Prof. Dr. Leandro L. Batista pelo entusiasmo criador de modelo de aula conectando diferentes áreas do saber nos processos de percepção e 
também por sua contribuição na qualificação esclarecendo, desafiando e inspirando a finalização do meu trabalho.

Agradeço aos meus colegas de percurso acadêmico da FEA: Luis Pilli, Marcelo Campomar, Fabiola Giglio, Luiza V. Bortoli; e da ECA: Ana Lucia A. Oshiro e Janiene dos Santos. Sem o apoio, parceria e companhia deles não teria a menor graça.

Agradeço ao meu painel de entrevistados pela disponibilidade, abertura e honestidade presente em cada contribuição: Prof. Dr. Gerald Zaltman, Prof. Dr. Carl D. Marci, Prof. Dr. Michael Brammer, Prof. Dr. M. Vinicius C. Baldo, Prof. Dr. Luiz E. Ribeiro do Valle, Prof. Dr. Fabio Babiloni, Prof. Dr. David, Sra. Silvia Quintanilha, Prof. Dr. Billy E. M. Nascimento, Sr. Karl Rosenberg, Prof. Dr. Philip Rosenberg, Sr. Pedro Camargo, Sr. Carlos Augusto Costa.

Agradeço a toda a equipe do PPGA, à Secretaria de Pós-Graduação e à Biblioteca da FEA-USP por toda a colaboração. 
“Eu sou cético da presunção da ciência de objetividade e concretude. Mas o ceticismo sobre o alcance atual da ciência, especialmente no que diz respeito à mente, não implica que o entusiasmo diminua para a tentativa de melhorar aproximações provisórias. Tenho o prazer de informar que alguns progressos foram feitos para a construção de uma ponte de duas vias entre neurobiologia e a área de humanas, assim, uma melhor compreensão do conflito humano pode ser fornecido. Estou ainda mais esperançoso hoje que tal ponte, aparentemente utópica, pode tornar-se realidade e estou otimista de que vamos desfrutar de seus benefícios sem ter que esperar mais um século" Antonio Damasio, Erro de Descartes, 2005. 


\section{RESUMO}

À medida que se avança no século XXI observamos a diversidade humana, cada vez em maior número, convivendo e interagindo a todo o momento. As dificuldades aumentam quando a diversidade se dá além de diferentes sexos, idades, mas também por diferentes opiniões e as várias formas de expressão e comportamento das pessoas, principalmente aqueles não conscientes. Nesse contexto vive-se o desencadeamento de uma crise das metodologias clássicas de investigação, vistas como limitantes e pouco esclarecedoras para o entendimento de que, em um mesmo indivíduo, podem existir estilos de consumo distintos, não conscientes, além de que o entrevistado pode, de maneira intencional ou não intencional, compreender mal, interpretar mal ou até mesmo enganar o pesquisador. O objetivo da dissertação foi avaliar se o neuromarketing pode ser uma nova área de colaboração ao entendimento do consumidor, ser capaz de obter as informações não declaradas do indivíduo, pela captura das informações cerebrais, adicionando assim conhecimento para o processo do entendimento de seu comportamento de consumo, validando-o como uma nova área de cooperação. Por meio de revisão bibliográfica e pesquisa empírica buscou-se identificar, entender e com isso resumir conceitos básicos sobre o neuromarketing, seu entendimento, suas formas de medição e técnicas, suas contribuições e limitações, preocupações e expectativa de futuro. Como resultado obteve-se que há uma diferença entre o entendimento do público acadêmicos entrevistado sobre neuromarketing versus o que se observa entre os estudos de comportamento do consumidor em práticas no mercado. Essas diferenças vão além das técnicas empregadas no estudo. Encontrou-se uma diversidade de conceitos técnicos, aplicações em marketing, vantagens e limitações, preocupação ética e diferentes visões de futuro. Predominantemente encontra-se um cenário típico de um assunto novo, onde várias opiniões são obtidas e buscou-se elencar as áreas de concordância até o momento. A busca pelo maior conhecimento da mente, transforma-a em um orgão prático, capaz de se moldar para intermináveis autoaperfeiçoamentos. Mas, apesar das imagens da mente carregarem peso de autoridade na ciência, seus significados como input científico são válidos, mas não oferecem ao público a clareza de que podem ser ainda utilizados como suporte imediato. $\mathrm{O}$ funcionamento do cérebro não é simples e natural e sim mediado na maneira que se conhece, entende e visualiza os estímulos e também pelo contexto social, político e econômico no qual o indivíduo pertence e convive. Portanto, conclui-se que o neuromarketing é uma aplicação da neurociência para maior entendimento dos comportamentos do consumidor e mais uma alternativa que, como qualquer outra pesquisa de mercado, por si só, não oferecerá um diagnóstico exaustivo para a pergunta do problema. Recomenda-se o uso em conjunto com outras metodologias, sempre levando em conta a particularidade de cada uma, seja pela especificidade da amostra, coleta de dados, análise dos mesmos e as conclusões com as devidas ressalvas, buscando sempre seguir a ética e os detalhes de cada mercado. Como sugestão seria importante contínuas investigações que validem e formem um arcabouço de conhecimento de investigações de comportamento. 


\begin{abstract}
As the life progress through the twenty-first century we see human diversity in an increasing growth, living and interacting in a faster and higher frequency. The difficulties to understand their behavior increase when the range of variety goes beyond genders, ages, through different opinions and various forms of expression and behavior, especially those of unconscious reasons. In this context one lives up triggering a crisis of classical methodologies of research, seen as limiting and not helpful to the understanding that, in the same individual, there may be distinct styles of consumption, unconscious, and that the interviewee can intentionally or unintentionally, misunderstand, misinterpret, or even mislead the researcher. The aim of this work was to assess whether neuromarketing may be a new area of collaboration to the understanding of the consumer, and by doing so being able to obtain unreported information of the individual by capturing the information in the brain, thereby adding knowledge to the process of understanding your consumer behavior, validating it as a new area of cooperation. Through literature review and empirical research the idea of the stydy was to identify, understand and summarize the knowledge captured from academics and executives from research companies, the basics concepts of neuromarketing, its understanding, its ways of measuring and techniques, its contributions and limitations, and therefore its concerns and expectations of the future. As a result it was found that there is a difference between the academic's understanding about neuromarketing versus what is observed in studies of consumer behavior in the market practices. These differences go beyond the techniques employed in the study. We found a diversity of technical concepts, applications in marketing, advantages and limitations, ethical concerns and different visions of the future. Predominantly we've found a scenario that is typical of a new area of study, where many different opinions are obtained and where we tried to rank the areas of agreement so far. The quest for greater knowledge of the mind, transform it with a body capable of practical shape for endless self-improvement. But despite that the images of the mind carry the weight of authority in science, their scientific input and their meanings are valid, but not a clear offer to the public as to be used as immediate support. The functioning of the brain is not simple and natural but mediated with interferences as the ways it recognizes, understands and visualizes the stimuli and also by the social, political and economic context in which the individual belongs and lives. Therefore we conclude that neuromarketing is an application of neuroscience to better understanding of consumer behavior and another alternative to add to the list of market research, and like any other option, it does not provide by itself a comprehensive assessment of the problem to the question. It is recommended to use neuroscience in its application to consumer in conjunction with other methodologies, always taking into account the particular features of each one, the specificity of the sample, the data collection, the analysis and combination of data from different studies and its conclusions with appropriate caveats, always trying to follow the ethics and details of each market. As a suggestion from this study it would be important to a continue research to validate and form a framework of knowledge of consumer behavioral research, as well as how to combine different areas and data from other sciences.
\end{abstract}




\section{SUMÁRIO}

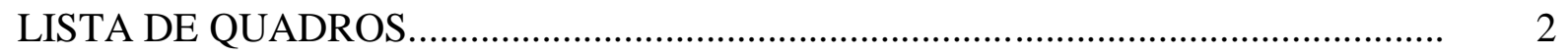

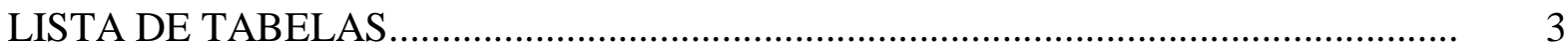

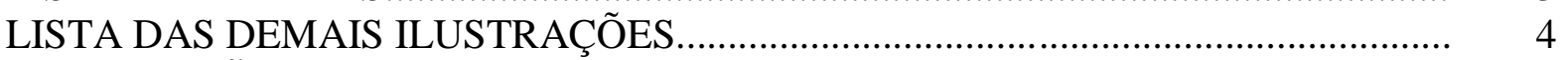

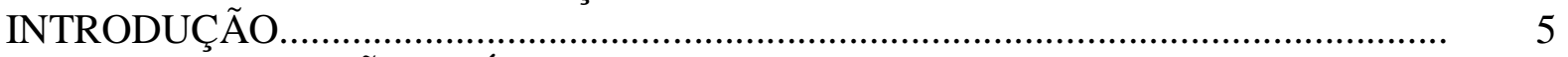

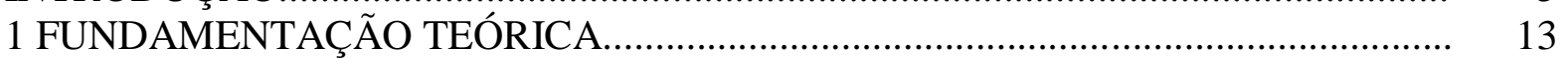

1.1. Um panorama sobre o processo decisório......................................................... 13

1.2. As etapas dos processos psicológicos do comportamento.................................... 18

1.3. Diferentes contribuições para o estudo do comportamento.................................. 25

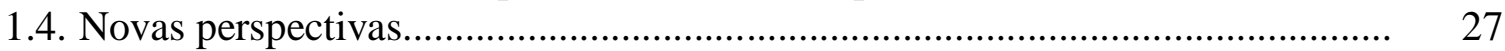

1.5. Mapeamento das técnicas de investigação de comportamento............................. 32

1.6. Análise semiótica na busca por representações mentais...................................... 35

1.7. A contribuição da ciência cognitiva para o estudo do comportamento................ 42

1.8. A neurociência para conhecimento do comportamento do consumidor............... 53

1.9. Conclusão - Resumo das contribuições da Neurociência dentro do estudo do

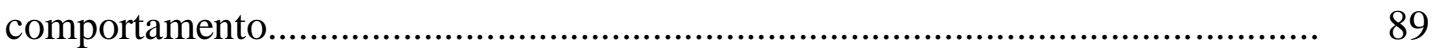

2. MÉTODO DA PESQUISA DE CAMPO............................................................ 95

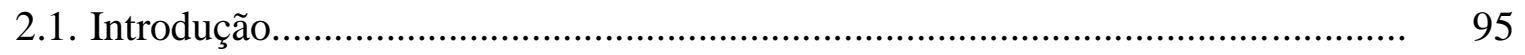

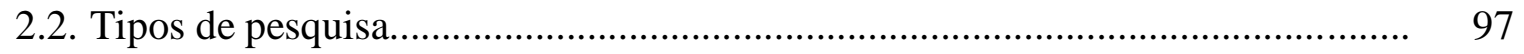

2.3. Métodos e técnicas de coleta de dados.............................................................. 99

2.4. Seleção das fontes dos dados........................................................................... 107

2.5. Procedimentos analíticos........................................................................ 110

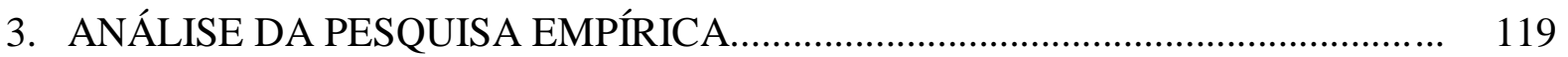

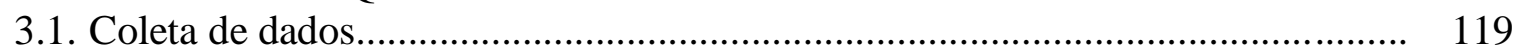

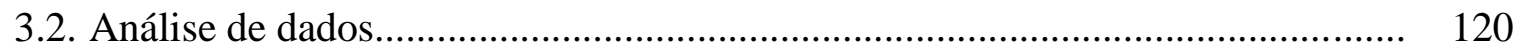

3.2.1. Envolvimento com comportamento..................................................... 122

3.2.2. Razões para o estudo........................................................................ 122

3.2.3. O envolvimento com a neurociência e as técnicas mais familiares........... 123

3.2.4. Definição do neuromarketing................................................................ 124

3.2.5. Possibilidades de explorações com neuromarketing para fases de

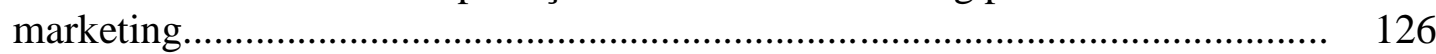

3.2.6. Técnicas utilizadas no neuromarketing................................................ 127

3.2.7. Vantagens e limitações de sua utilização................................................ 129

3.2.8. Preocupações sobre o tema................................................................ 130

3.2.9. O futuro do neuromarketing................................................................ 131

3.2.10. Fontes declaradas de informações........................................................... 132

3.3. Conclusões da pesquisa de campo................................................................... 133

4. Considerações finais, limitações e recomendações....................................................... 139

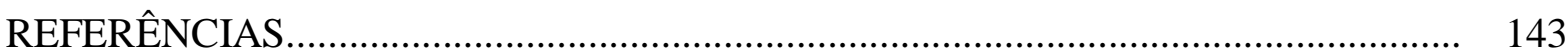

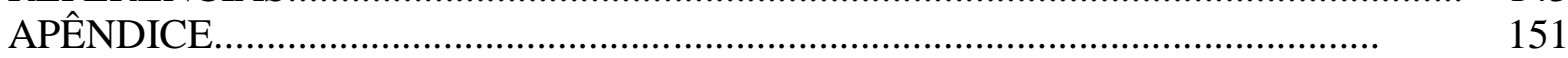




\section{LISTA DE QUADROS}

Quadro 1 - Adaptação de modelos de comportamento do consumidor.

Quadro 2 - Contribuições das ciências do comportamento a problemas específicos de marketing.

Quadro 3 - Utilização de diferentes disciplinas e o comportamento.

Quadro 4 - Comparação de várias técnicas de marketing.

Quadro 5 - Tipos e características da memória.

Quadro 6 - A biometria e suas diversas medições.

Quadro 7 - Diferentes métodos de investigação do comportamento, fases de decisão e suas contribuições.

Quadro 8 - Modelo de tipologia de entrevista.

Quadro 9 - Tipos de pesquisa.

Quadro 10 - Domínios possíveis da análise de conteúdo.

Quadro 11 - Resumo das 10 categorias da análise de conteúdo 


\section{LISTA DE TABELAS}

Tabela 1 - Características de sites sobre neuromarketing............................................ 72

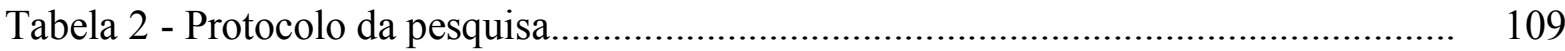

Tabela 3 - Neuromarketing: o que se mede em marketing......................................... 116

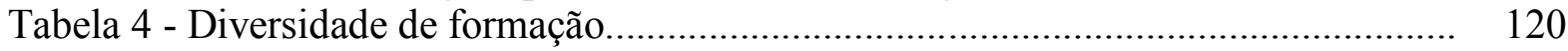

Tabela 5 - Razões para estudar comportamento.......................................................... 122

Tabela 6 - Técnicas utilizadas na neurociência........................................................... 124

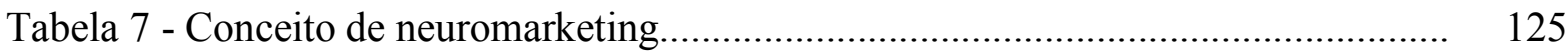

Tabela 8 - O que é possível medir em neuromarketing................................................. 126

Tabela 9 - Diversidade de formação.......................................................................... 127

Tabela 10 - Técnicas de medição utilizadas.............................................................. 128

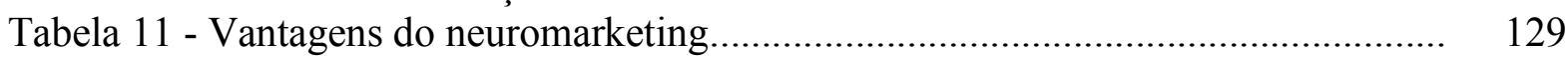

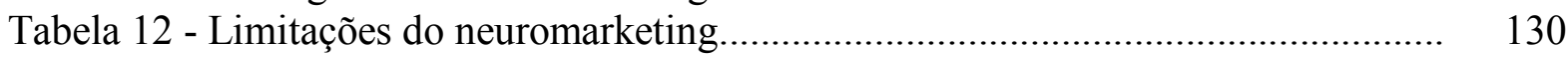

Tabela 13 - Preocupações com neuromarketing............................................................. 131

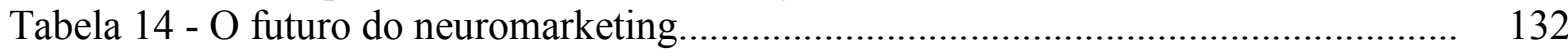

Tabela 15 - Fontes para o assunto neurociência e comportamento................................... 132 


\section{LISTA DAS DEMAIS ILUSTRAÇÕES}

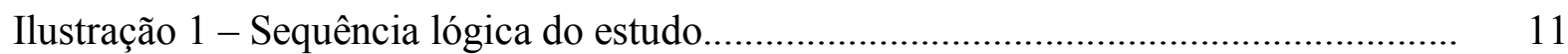

Ilustração 2 - Cronologia dos estudos do comportamento do consumidor......................... 14

Ilustração 3 - O modelo simples de processo de tomada de decisão do consumidor........ 15

Ilustração 4 - Modelo básico do processo de decisão do consumidor................................ 16

Ilustração 5 - Estágios do processo de decisão de compra e variáveis influenciadoras.... 17

Ilustração 6 - Modelo da Pirâmide de Brand Equity.......................................................... 22

Ilustração 7 - Evolução das teorias comportamentais. ..................................................... 30

Ilustração 8 - Formulação Pierciana.................................................................................... 37

Ilustração 9 - Resumo da teoria do Signo de Peirce. ...................................................... 38

Ilustração 10 - Anúncio Halifax. ................................................................................. 40

Ilustração 11 - Testes disponíveis ITA........................................................................ 44

Ilustração 12 - Modelo de ativação interativa do reconhecimento de palavras. ............... 48

Ilustração 13 - Operação do sistema de memória para o comportamento. ........................ 51

Ilustração 14 - As múltiplas relações entre memória, pensamento e comportamento....... 52

Ilustração 15 - Processos paralelos no cérebro. ............................................................... 54

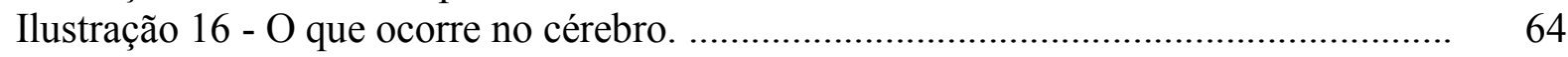

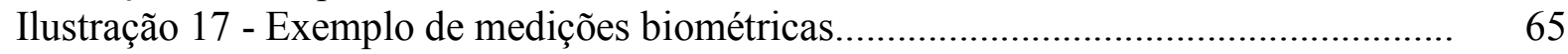

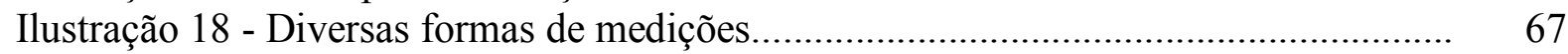

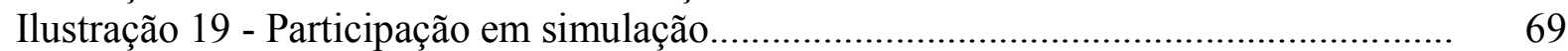

Ilustração 20 - Estudos de aplicação de EEG e biometria da Empresa NeuroFocus. ....... 70

Ilustração 21 - Experimento com mapeamento de neurônios e aplicação em robôs......... 79

Ilustração 22 - Mynd, o EEG do futuro. ........................................................................ 82

Ilustração 23 - O sistema epidérmico eletrônico. .......................................................... 83

Ilustração 24 - Ciclo de desenvolvimento de produto....................................................... 86

Ilustração 25 - Desenvolvimento da análise de conteúdo................................................. 113 


\section{INTRODUÇÃO}

O contexto no qual o estudo se insere é o de complexidade. À medida que se avança no século XXI observa-se a diversidade humana, cada vez em maior número, convivendo e interagindo a todo o momento. As dificuldades aumentam quando a diversidade não se dá somente nas referências como sexo, idade, raça, mas também nas diferentes opiniões, preferências, interesses e as várias formas de expressão e comportamento das pessoas, principalmente aqueles não conscientes.

Nesse cenário, como descrito em Lipovetsky (2008) é preciso observar que a civilização moderna, individualista e democrática, deu peso e alívio excepcionais em uma área psicológica e social sem precedentes históricos. A sociedade hipermoderna aparece como uma sociedade de inflação decepcionante. Quando se promete felicidade a todos e - se anuncia prazeres em cada esquina - a vida diária é uma provação. Mais ainda quando a busca por qualidade de vida está presente em vários temas do cotidiano do indivíduo no presente momento (amor, sexualidade, alimentação, habitação, ócio...). Esse é o novo horizonte de expectativas dos indivíduos: todos querem superar a situação atual, conhecer gozos e sensações renovadas. Ao buscar a felicidade cada vez mais longe, ao exigir sempre mais, torna-se indefeso diante das amarguras do presente e dos sonhos futuros. Nessa visão progressista, se concebe o futuro sempre como superior ao presente, partindo da ideia que a história avança necessariamente para garantir a liberdade e a felicidade do gênero humano. A ciência e a técnica alimentam a esperança de um progresso irreversível e contínuo. Lipovetsky (2008) afirma que as pessoas vivem em um contexto de pressão em busca de suas criações de necessidades e bem-estar. O mundo aspira participar do consumo mundial, do ócio e das marcas.

O momento descreve, portanto, uma oportunidade ao aumento exponencial das ofertas, não somente em produtos e serviços ao mercado, mas também da diversificação de suas formas de negócio, das diferentes abordagens ao cliente e também das inúmeras maneiras de realizar a comunicação para atingir aos vários perfis de público, ou até mesmo, ao próprio indivíduo em seus distintos momentos de necessidades. No entanto, entender o comportamento do consumidor em uma sociedade marcada pela complexidade para a elaboração da oferta 
relevante envolve o estudo de muitas variáveis. Mudanças nas dinâmicas sociais, novas tecnologias, novos estilos de vida e consumidores mais conscientes também provocaram o desafio à hegemonia da comunicação de massa, em particular da propaganda como fonte de informação, desencadeando nessa forma de comunicação uma crise de credibilidade, uma vez que os receptores das mensagens estão cientes que os anunciantes querem convencê-los a comprar - e os consumidores possuem uma postura mais crítica e cética, confirmando a diminuição do poder de persuasão desta ferramenta de comunicação (CRESCITELLI, 2004).

Nessas circunstâncias, com a pluralidade de ofertas, onde há um consumo do efêmero, em que todos buscam um consumo futuro melhor, evidencia-se a importância do conhecimento, não apenas das necessidades específicas declaradas pelos indivíduos, mas de suas reais motivações, conscientes ou inconscientes. Com isso, as propostas das marcas podem oferecer algo de maior valor em comparação aos concorrentes e desenvolver assim não apenas a intenção de compra, mas também a maior fidelidade as suas ofertas.

No cenário apresentado, a pesquisa de comportamento e suas práticas de investigação devem ser parte integrante e contínua do fluxo de negócio e não apenas uma área de apoio à área de marketing. Para obterem sucesso nessa empreitada, as empresas estão permanentemente investindo em técnicas que possam esclarecer o rol de informações e melhorar o entendimento do comportamento dos consumidores, tais como, pesquisas de mercado ad hoc, painéis demográficos e psicográficos e ainda, projetos exploratórios tais como entrevistas utilizando técnicas projetivas, como descrito em Malhotra (2011), aquelas usadas em situações de pesquisa em que o entrevistado não consegue ou não deseja responder a uma pergunta diretamente, onde se busca encontrar suas motivações, seus desejos a partir de declarações obtidas dos entrevistados que se pedidas diretamente não revelarão o que está mantido em seu subconsciente. Para Churchill Jr (1996), a obtenção de dados de comportamento do consumidor se dá pelo emprego da observação ou metodologias declaratórias, ou ainda por meio de utilização de questionários, onde o entrevistado conscientemente responde às perguntas sobre o objeto de estudo de forma oral ou escrita ou é observado em suas atividades rotineiras ou ainda na própria observação de suas decisões. Seu comportamento é interpretado e até mensurado por meio de diferentes técnicas que facilitem o entendimento de seus hábitos de consumo. 
No entanto, vive-se um desencadeamento de uma crise das metodologias clássicas de investigação. Essas são vistas como limitantes e pouco esclarecedoras para o entendimento de que em um mesmo indivíduo possam existir estilos de consumo distintos, dependentes de seus diversos papéis na sociedade, de seus diferentes momentos durante as fases de vida e até mesmo dentro do mesmo dia. De acordo com Malhotra (2011, p.136) na entrevista direta, o entrevistado pode, de maneira intencional ou não, compreender mal, interpretar mal ou enganar o pesquisador. Nesse caso, técnicas projetivas, ou métodos não tradicionais, podem aumentar a validade das respostas disfarçando o propósito. Isso se dá especificamente em questões cuja abordagem é de cunho pessoal, delicada ou sujeita a regras sociais, para exploração das motivações, crenças e atitudes que atuam em nível subconsciente.

O indivíduo passa atualmente por um movimento contínuo de mutação. Diante de tal complexidade, a pluralidade de métodos aplicados ao entendimento do comportamento humano oferece resultado incompleto, imutável e restrito para explicar as reações dos indivíduos e acompanhar suas alterações; o que se busca, com novas metodologias, é melhorar a acuidade das diretrizes dos dados obtidos possibilitando melhorar as estratégias para a atuação das marcas no mercado. Além dos altos custos da propaganda e o surgimento de novas formas e mídias capazes de potencializar todo o mix de comunicação, é fundamental discutir a questão das mudanças de comportamento que vem ganhando força desde os anos 1990, quando os clientes perceberam que podiam fazer valer seus direitos. (POON; PRENDERGAST, 2006).

As pesquisas de marketing presentes nas ciências sociais aplicadas, bem como a semiótica na ciência da comunicação, a psicologia nas ciências humanas, a neurociência nas ciências biológicas são exemplos das diversas áreas de conhecimento que propõem métodos para entender como os indivíduos pensam, agem e interagem com produtos e serviços, as similaridades e diversidades existentes em seu processo de escolha, o que querem, o que pensam e as influências que existem e afetam suas decisões de consumo.

O estudo do comportamento na administração de marketing é entendido como a observação dos consumidores em seu processo de decisão de compra, sua busca, sua compra, seu uso, sua avaliação e seu descarte de produtos, serviços ou ideias, com a expectativa de obter maiores informações para elaborar propostas que satisfaçam suas necessidades e suas demandas. $\mathrm{O}$ estudo pode englobar questionamentos como, por exemplo, o quê se quer comprar, de quem, 
onde, quanto, quando e com qual frequência, bem como a real motivação para a compra. Após a utilização do produto ou serviço investiga-se ainda em quais circunstâncias é usado ou consumido, as reações, preferências e repetições de compra. Estudos dessa natureza dedicamse ao aprendizado dos significados específicos que os produtos têm para os consumidores.

Para Schiffman e Kanuk (2000) o estudo do comportamento do consumidor é interdisciplinar, baseia-se nos conceitos e teorias acerca das pessoas que foram desenvolvidos por cientistas em disciplinas tão diversas quanto a psicologia, a sociologia, a psicologia social, a antropologia cultural e a economia. Os estudiosos do comportamento do consumidor como Ariely e Berns (2010) têm utilizado como suporte as mais variadas áreas, a antropologia, a sociologia, a psicologia e, mais recentemente, a inclusão da neurociência, para entender de maneira mais profunda as preferências e comportamentos diante dos estímulos oferecidos pelos produtos de consumo. Alguns exemplos de onde esse trabalho interdisciplinar é perceptível estão nas pesquisas empíricas de investigação das atitudes feitas no campo, nas pesquisas de percepção do consumidor feitas com análises semióticas, nas investigações científicas cognitivas das representações mentais. Nos estudos que utilizam imagens da mente com métodos da neurociência, como SST (steady state topograpy) - uma medição avançada e imediata das reações elétricas do escalpo a estímulos, medida por meio de um eletroencefalograma - e o fMRI (functional Magnetic Resonance Imaging) - um escâner que pode marcar áreas muito pequenas que foram estimuladas - são realizados testes cerebrais que colocam o consumidor em estado quase hipnótico na tentativa de compreender suas motivações de consumo, suas atitudes e seu estilo de vida. Novas formas de investigação têm como proposta oferecer um maior entendimento dos comportamentos oriundo da localização e qualificação dos diversos estímulos e suas reações na influência ao consumidor. Elas podem ser utilizadas antes e durante as execuções das estratégias de comunicação para obtenção de maiores informações, permitindo ajustes e possibilitando melhores resultados para o negócio.

O neuromarketing surge da aplicação dos métodos da neurociência e suas ferramentas na obtenção de um maior arcabouço de conhecimento, com a proposta de agregar às informações comportamentais as motivações ocultas no inconsciente da mente que direcionam os indivíduos no intuito de melhorar a elaboração de ofertas de valor para o cliente ou consumidor. A questão a ser explorada nesta dissertação é investigar quais são as informações novas que podem ser obtidas através do neuromarketing e se as mesmas ajudam no esclarecimento do conhecimento sobre os indivíduos, oferecendo maior suporte com os 
resultados apresentados, propiciando assim melhor compreensão e evolução do conhecimento sobre o tema até o momento.

Portanto, diante do exposto, a proposta da dissertação é verificar a seguinte questão problema:

\section{Avaliar se o neuromarketing pode ser uma nova área de colaboração ao entendimento do consumidor.}

Para atingir o objetivo proposto o presente estudo teve início com o levantamento bibliográfico para a construção de um arcabouço teórico sobre o comportamento do consumidor, do processo que envolve uma decisão, propiciando o entendimento dos antecedentes e o contexto de estudos anteriores em aplicação em marketing. Após a investigação das informações colhidas, realizou-se uma investigação de campo para averiguar novos conhecimentos sobre o tema por meio de pesquisa exploratória com pessoas envolvidas no estudo de novos rumos.

Na fundamentação teórica, como Capítulo 1, busca-se abordar alguns métodos já estudados envolvendo decisões e seus modelos, aprofundar o entendimento dos processos psicológicos, como a origem das necessidades, suas motivações, a busca por informação e integração no processo de tomada de decisão, que culmina em algum comportamento; após a tomada de decisão a satisfação ou insatisfação gerada pela satisfação da necessidade. Ainda nesse capítulo, procura-se levantar, na literatura disponível, novas perspectivas e metodologias que possam contribuir para estudos do comportamento humano já utilizadas atualmente em combinação com outros procedimentos. Uma das abordagens atuais é a oferecida pela semiótica e suas diferentes correntes e abordagens sobre os signos e o processo de significado em cada indivíduo, utilizada para entender comunicação de marketing. Outra abordagem é a análise da ciência cognitiva e suas contribuições evidenciadas em testes como o ITA (implicit test association) ou teste de associação implícita, e também o priming, um recurso utilizado para aumentar a recordação de algum elemento de comunicação. Ao final analisa-se a neurociência, seu histórico, suas técnicas e mensurações, aplicações acadêmicas, aplicações em pesquisas de mercado encontradas em pesquisa bibliográfica, cases de aplicação desta área do saber e sua averiguação em campo em estudos existentes. 
Adicionalmente aos levantamentos mencionados, aferiu-se, em pesquisa de campo por meio de utilização de entrevistas de profundidade, a opinião sobre neuromarketing por diferentes óticas. Portanto, o Capítulo 2 é composto pela pesquisa de campo, com seu protocolo de aplicação, seu objetivo, justificativa, coleta de dados e suas descobertas. Estarão presentes nessa parte as opiniões de vários especialistas de diversas áreas teóricas ou práticas como neurocientistas, psicólogos, administradores, pesquisadores e executivos de empresas de pesquisa de mercado, suas vivências e opiniões, contribuindo assim com um arcabouço de conhecimento da teoria, prática e aplicação da neurociência. Mais especificamente será explorado seu foco em marketing, técnicas, as vantagens e desvantagens oferecidas, as possíveis contribuições e limitações na aplicação ao comportamento do consumidor, bem como o futuro previsto para a área. Busca-se com esse levantamento obter um mapeamento da aplicação da neurociência em marketing, sua definição como área de estudo, seus métodos, análises e contribuições.

Na última seção do estudo encontram-se as considerações finais do trabalho. É onde se obtém o resumo, em linhas gerais, de todo o conteúdo encontrado a partir das diferentes discussões das seções anteriores. Esta é complementada pela apresentação das limitações do estudo, acrescidas das considerações sobre o trabalho como também das recomendações propostas para os próximos passos da investigação sobre o tema.

Ao final, em Apêndices, são apresentadas as tabelas das entrevistas em profundidade.

Na Ilustração 1 a seguir, encontra-se a sequência lógica do estudo, com o detalhamento proposto em cada capítulo da dissertação. Esta imagem representa uma forma de organizar a leitura e facilitar o entendimento. 


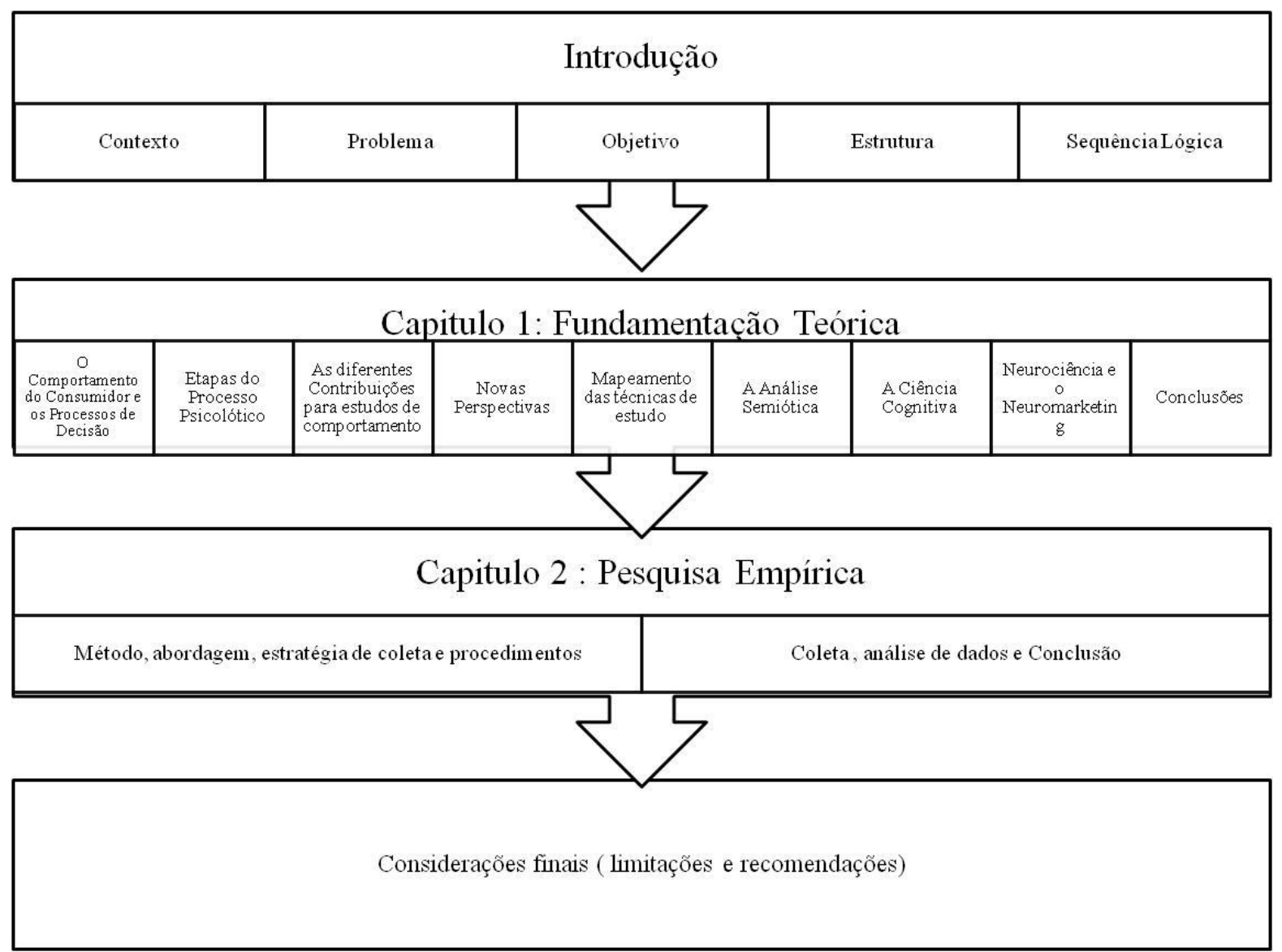

Ilustração 1 - Sequência lógica do estudo 


\section{FUNDAMENTAÇÃO TEÓRICA}

O primeiro capítulo contemplou uma revisão da literatura, identificando as diferentes linhas de pensamento sobre cada um dos conceitos relevantes para o tema em estudo, primeiramente abordando um panorama geral do comportamento do consumidor e os processos de decisão. Após esse traçado geral, se buscou fazer um entendimento e análise das necessidades e motivações de um indivíduo para saciar uma tensão. Em seguida, analisa-se o comportamento do indivíduo pela psicologia cognitiva e depois por outras duas diferentes perspectivas de estudos, primeiramente a semiótica e as suas representações mentais e depois a contribuição da neurociência para o estudo do comportamento do consumidor.

Dado o teor de ineditismo do tema em sua aplicação na área de consumo, várias disciplinas científicas serão analisadas a fim de permitir uma busca de referência nos diversos campos da investigação do comportamento do consumidor: o campo cognitivo, com foco nos comportamentos de consumo nas áreas de marketing e psicologia; e o não cognitivo, tratados como novas áreas de comportamento, como semiótica e a neurociência.

\subsection{Um panorama sobre o processo decisório}

Para Oliveira (2007) as teorias do comportamento do consumidor começaram a se delinear nos anos 1970, expandindo os estudos sobre atitudes para conceitos mais amplos de processamento de informações: como os consumidores adquirem, armazenam em suas memórias e as utilizam posteriormente para decidir sobre suas compras. Nesse momento, começam a surgir os modelos de comportamento do consumidor cuja função foi organizar o conhecimento a respeito do tema. Atualmente, segundo a autora, o processo é estocástico apenas probabilidades podem ser determinadas - é imprescindível que haja contribuições interdisciplinares para o entendimento do mesmo.

O conceito de comportamento do consumidor teve uma mudança de abrangência, de acordo com a autora, que menciona o estudo de Howard e Sheth (1969), quando havia um foco nas escolhas de marcas repetidamente por meio de um conjunto de motivos e critérios. Robertson 
et al (1984) iniciam a busca pelo entendimento do por que do comportamento do consumidor. Com Howard (1989) evolui-se para entender o como e o porquê do comportamento. Já Salomon (2002) define o tema como o processo envolvendo seleção, compra e uso de produto, serviço, ideia ou ainda experiência, ampliando ainda mais o campo do comportamento em busca da satisfação da necessidade. Blackwell et al (2005) definem o comportamento como as atividades com as quais os consumidores se ocupam quando buscam e obtêm o que consomem, sendo produtos ou serviços, campo que envolve as atividades de consumo. A seguir Ilustração 2 que apresenta uma cronologia dos estudos já realizados.

\begin{tabular}{|c|c|c|c|c|c|c|c|c|c|}
\hline 1969 & 1980 & 1984 & 1989 & 1999 & 2000 & 2001 & 2002 & 2003 & 2005 \\
\hline $\begin{array}{l}\text { - Howard e } \\
\text { Sheth } \\
\text { - Escolha } \\
\text { repetida de } \\
\text { marcas }\end{array}$ & $\begin{array}{l}\text { - Gade } \\
\text { - Relaçao } \\
\text { entre } \\
\text { consumido } \\
\text { re } \\
\text { produtos }\end{array}$ & $\begin{array}{l}\text {-Robertson } \\
\text { etal } \\
\text { - Sabero por } \\
\text { quê dos } \\
\text { atos de } \\
\text { consumo }\end{array}$ & $\begin{array}{l}\text { - Howard } \\
\text { - Como } \\
\text { comprame } \\
\text { consomem } \\
\text { os } \\
\text { consumido } \\
\text { res }\end{array}$ & $\begin{array}{l}\text { - Sethet al } \\
\text { - Atividades } \\
\text { fisicase } \\
\text { mentais } \\
\text { que } \\
\text { resultam } \\
\text { em } \\
\text { decisões }\end{array}$ & $\begin{array}{l}\text {-Schiffman } \\
\text { e Kanuk } \\
\text { - Comporta } \\
\text { mentos } \\
\text { para } \\
\text { satisfazer } \\
\text { necessidad } \\
\text { es }\end{array}$ & $\begin{array}{l}\text {-Hawkins et } \\
\text { al } \\
\text { - Tomada de } \\
\text { decisão } \\
\text { para } \\
\text { alcançar } \\
\text { satisfação }\end{array}$ & $\begin{array}{l}\text {-Salomon } \\
\text { - Processos } \\
\text { para } \\
\text { satisfazer } \\
\text { necessida } \\
\text { dese } \\
\text { desejos }\end{array}$ & $\begin{array}{l}\text {-Minore } \\
\text { Mowen } \\
\text { - Procesos } \\
\text { de troca }\end{array}$ & $\begin{array}{l}\text {-Blackwell } \\
\text { etal } \\
\text {-Campo de } \\
\text { estudo das } \\
\text { atividades } \\
\text { do } \\
\text { consumido } \\
\text { r }\end{array}$ \\
\hline
\end{tabular}

Ilustração 2 - Cronologia dos estudos do comportamento do consumidor

Belch e Belch (2008) mais recentemente definem o comportamento do consumidor "como o processo e as atividades que pessoas desempenham quando estão procurando, selecionando, comprando, usando, avaliando e descartando produtos e serviços para satisfazerem suas necessidades e desejos.” (2008, p. 105). Para a American Marketing Association (AMA, 2008), esta definição torna-se mais abrangente: é a interação dinâmica da percepção, do comportamento e do ambiente no qual os seres humanos conduzem as trocas em suas vidas. Portanto, as empresas precisam entender como clientes preferem uma marca à outra entre as várias alternativas e tomam sua decisão de compra. Precisam conhecer suas necessidades específicas e transformá-las em intenção de compra, processo de conhecimento que envolve o entendimento das etapas do processo de decisão em observação do comportamento e também dos processos psicológicos envolvidos no mesmo.

Há vários modelos que estudam o comportamento do consumidor, de acordo com Oliveira (2007) detalhados no Quadro 1 No entanto, o detalhamento das fases iniciais de reconhecimento da necessidade, busca de informação e avaliação das alternativas de compras é o foco de interesse das empresas para poder desenvolver e oferecer seus produtos e serviços em adequação ao esperado e preferido pelos consumidores. 
Quadro 1 - Adaptação de modelos de comportamento do consumidor

\begin{tabular}{|c|c|c|c|c|c|}
\hline AUTORES & Blackwell et al & Minor e Mowen & Kotler e Keller & Solomon & Robertson et al \\
\hline \multirow{8}{*}{ ENFOQUE } & \multicolumn{4}{|c|}{ ETAPAS DO PROCESSO DE DECISÃO DE COMPRA } & DECISÕES \\
\hline & $\begin{array}{l}\text { Reconhecimento de } \\
\text { necessidade }\end{array}$ & $\begin{array}{c}\text { Reconhecimento } \\
\text { do problema }\end{array}$ & $\begin{array}{l}\text { Reconhecimento } \\
\text { do problema }\end{array}$ & $\begin{array}{l}\text { Reconhecimento } \\
\text { do problema }\end{array}$ & $\begin{array}{l}\text { Consumir ou } \\
\text { poupar }\end{array}$ \\
\hline & $\begin{array}{l}\text { Busca de } \\
\text { informação }\end{array}$ & Busca & $\begin{array}{c}\text { Busca de } \\
\text { informações }\end{array}$ & $\begin{array}{c}\text { Busca de } \\
\text { informações }\end{array}$ & $\begin{array}{l}\text { Qual categoria } \\
\text { consumir }\end{array}$ \\
\hline & $\begin{array}{l}\text { Avaliação de Alter- } \\
\text { nativas Pré-Compra }\end{array}$ & $\begin{array}{c}\text { Avaliação das } \\
\text { Alternativas }\end{array}$ & $\begin{array}{c}\text { Avaliação das } \\
\text { Alternativas }\end{array}$ & $\begin{array}{c}\text { Avaliação das } \\
\text { Alternativas }\end{array}$ & $\begin{array}{l}\text { Qual marca } \\
\text { escolher }\end{array}$ \\
\hline & Compra & Escolha & $\begin{array}{c}\text { Decisão de } \\
\text { Compra }\end{array}$ & $\begin{array}{l}\text { Escolha do } \\
\text { Produto }\end{array}$ & Como comprar \\
\hline & Consumo & \multirow{3}{*}{$\begin{array}{l}\text { Avaliação Pós- } \\
\text { Compra }\end{array}$} & \multirow{3}{*}{$\begin{array}{l}\text { Comportamento } \\
\text { Pós-Compra }\end{array}$} & \multirow{3}{*}{ Resultados } & \multirow{3}{*}{$\begin{array}{l}\text { Como utilizar e } \\
\text { descartar o item } \\
\text { adquirido }\end{array}$} \\
\hline & $\begin{array}{c}\text { Avaliação Pós- } \\
\text { Consumo }\end{array}$ & & & & \\
\hline & Descarte & & & & \\
\hline
\end{tabular}

FONTE: OLIVEIRA, 2007, p. 25.

Outro exemplo de modelo de tomada de decisão do consumidor investigado é o de Schiffman e Kanuch (1997), onde unem os conceitos psicológicos, sociais e culturais em uma estrutura de trabalho facilmente entendida. Esse modelo tem três séries de variáveis - as variáveis de input ou as variáveis externas do ambiente mercadológico ou não; as variáveis de processo, ou as influenciadas pelo campo psicológico do consumidor; e as variáveis de output, ou as experiências anteriores com o produto. Este processo é demonstrado na Ilustração 3 a seguir:

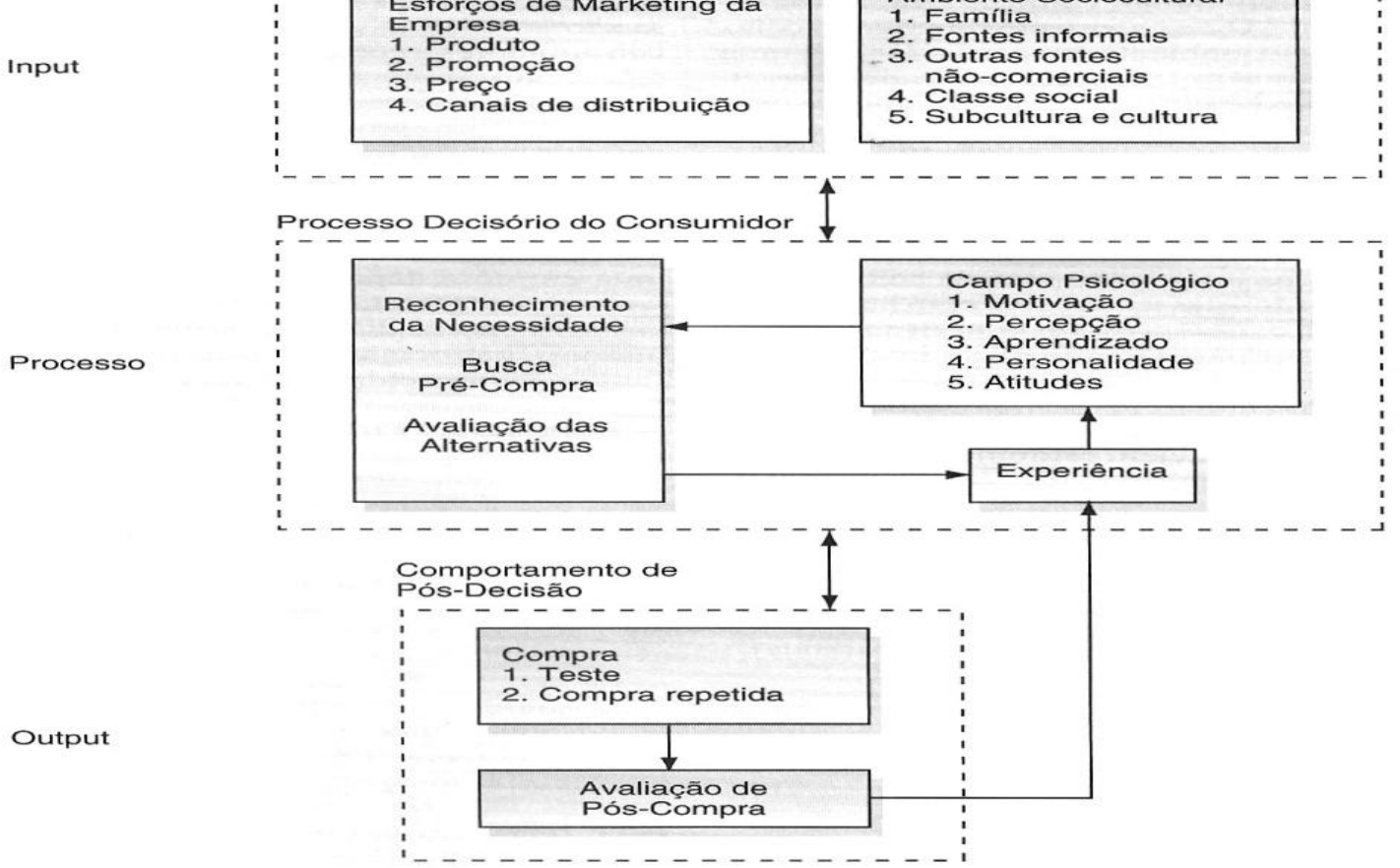

Ilustração 3 - O modelo simples de tomada de decisão do consumidor FONTE: SCHIFFMAN; KANUK, 1997, p. 400. 
Os modelos de comportamento do consumidor demonstram vários estágios no processo de tomada de decisão pelos quais o cliente passa quando está adquirindo algo, no qual se desenrolam importantes processos, sejam eles comportamentais ou processos internos/ psicológicos. (Ilustração 4 etapa B).

A - Etapas do processo de decisão de compra

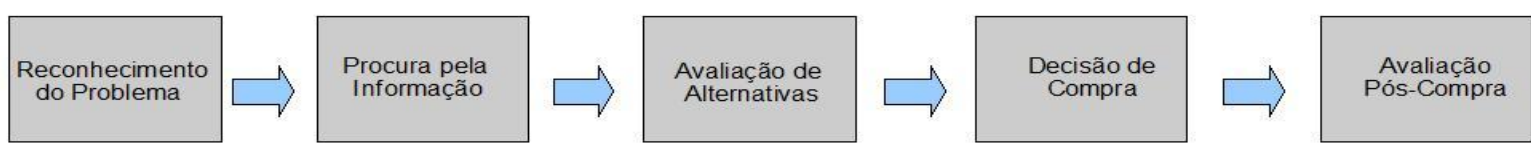

B- Processos psicológicos internos relevantes neste processo ( A )

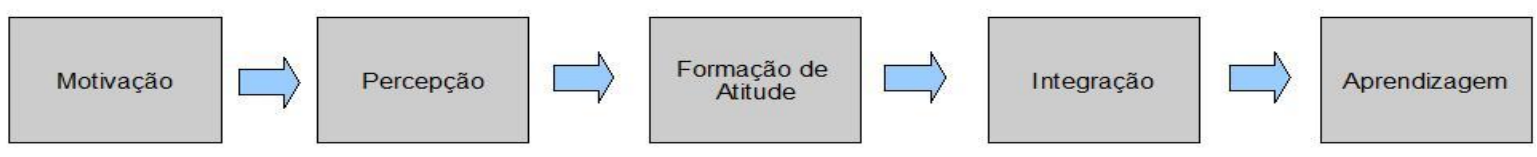

Ilustração 4 - Modelo básico do processo de decisão do consumidor FONTE: BELCH; BELCH, 2008, p. 107.

O modelo mencionado é encontrado em Belch e Belch (2008), mas também é consistente com o modelo de Blackwell et al (2005). Os autores destacam como as variáveis que influenciam e moldam as tomadas de decisão as diferenças individuais, ambientais e processos psicológicos; estas agem no processo em uma sequência que se retroalimenta como descrito na Ilustração 5. O esquema descreve que o reconhecimento de uma necessidade nasce com a motivação. A busca de informações é interna (processos de memória) e externa (ambientes sociais, familiares etc.). 


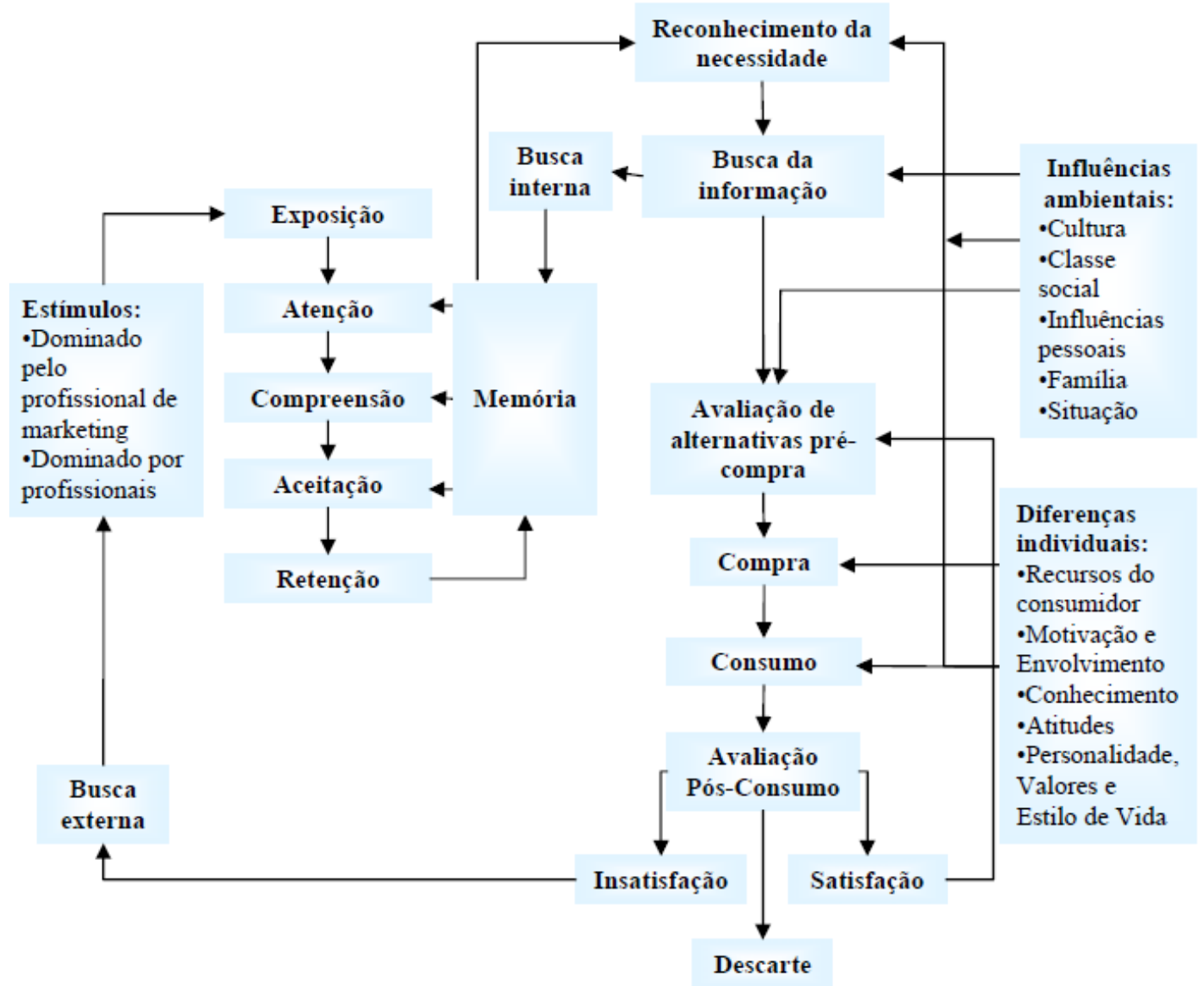

Ilustração 5 - Estágios do processo de decisão de compra e variáveis influenciadoras FONTE: BACKWELL et al, 2005, p. 86.

Em linha com Blackwell et al (2005) os autores KOTLER et al (2000) citam como influências externas: família, classe social, grupos de referência e cultural; como influências internas: motivação, percepção, atitude, integração e aprendizagem. As influências internas podem ser oriundas da motivação - teoria cognitiva que enfatiza os processos mentais internos; da psicologia - que enfatiza o comportamento observado, entendendo a mente como uma "caixa preta"; da atitude que pode ser favorável ou desfavorável e representam tendências proativas em relação a algum objeto ou dado, contendo componentes cognitivos, afetivos e comportamentais; ou da percepção - um processo ativo de construção sensorial.

O comportamento do consumidor, de caráter interdisciplinar, de acordo com Oliveira (2007) deve considerar que o ser humano é positivo, comportando-se para a racionalidade; é emocional, dirigido por afetos conscientes e inconscientes; é social, influenciado pelas regras de seu grupo; é dialético, conduzido pelas oposições da humanidade; é complexo, comportando-se de forma imprevisível em função de determinações e indeterminações que comandam suas decisões. Para comportar-se, a autora apresenta três processos de tomada de 
decisão: extenso, quando não há critério para avaliar algo, portanto envolve todas as fases de analise, é impactado pelo prévio nível envolvimento, diferenciação entre alternativas e disponibilidade de tempo; limitado, quando há regras preestabelecidas, atualizadas com novas alternativas disponíveis; rotineiro, quando a decisão não merece esforço, pois não há percepção racional do processo.

No entanto, para a finalidade deste estudo que se interessa por comportamentos não declarados e suas prováveis formas de pesquisa, o foco será dado aos processos psicológicos do processo de decisão para entrar no entendimento do lado das variáveis influenciadoras que não estão declaradas nas pesquisas tradicionais de mercado.

\subsection{As etapas dos processos psicológicos do comportamento}

Primeira etapa: Análise da Motivação

O início de um comportamento surge com o reconhecimento de uma necessidade existente e latente. Este é chamado de espaço cognitivo, onde as motivações direcionarão a ação para resolver a carência do indivíduo por meio da realização de determinado comportamento ou processo de decisão. Entende-se por motivação o que faz alguém agir em determinada situação em busca de uma recompensa ou com o intuito de evitar perdas (PESSOA, 2009). Para entender melhor as razões por detrás das compras dos clientes, os anunciantes buscam avaliar os fatores que influenciam seus estados motivacionais. Estes estados têm algumas funções: 1- função de direção, pois orientam o comportamento para um objetivo específico; 2função ativadora, por aumentarem o estado de alerta geral e energizarem o indivíduo para determinada ação; 3- função organizadora, por combinar componentes comportamentais individuais em uma sequência coerente, orientada para um objetivo (KANDEL et al, 2000).

As necessidades dos indivíduos são de origem fisiológica e psicológica, decorrentes de necessidades de reconhecimento, estima ou integração. Uma necessidade passa a ser um motivo quando alcança determinado nível de intensidade que leva uma pessoa a agir (KOTLER; KELLER, 2007). Os autores dizem que são três as teorias sobre motivação humana: as teorias de Sigmund Freud, de Abraham Maslow e de Frederick Herzberg, sendo 
que cada uma traz implicações diferentes para a estratégia das empresas. A teoria de Freud diz que as forças psicológicas que formam o comportamento são inconscientes e que ninguém chega a entender por completo suas próprias motivações. Os estímulos fornecidos por um produto ou serviço podem ter sinais menos conscientes do que os declarados, portanto, para explicar as motivações de decisões de compra, estas só podem ser identificadas pela investigação do subconsciente. Outra abordagem das mais conhecidas para entender a motivação dos consumidores é a teoria de hierarquia das necessidades de Abraham Maslow, onde em sua interpretação é uma escala que parte das necessidades Inferiores às Superiores: Fisiológica, Segurança, Associações, Necessidade do Ego, Autorrealização. Na prática, é difícil que os indivíduos se movam por esta hierarquia em uma sequência lógica e linear. Por outro lado, o modelo é útil para que as empresas determinem quais necessidades pretendem satisfazer com seus produtos e serviços, estabelecendo diferentes níveis entre os diversos segmentos de consumo. Por último, para Herzberg os fatores que motivam a compra são os insatisfatores, que causam insatisfação, e os satisfatores, aqueles causadores de satisfação. A ausência de insatisfação não seria suficiente para motivar, sendo necessário também estarem presentes os satisfatores.

Para Schiffman e Kanuk (2000) a motivação é a força interior de um indivíduo que o impele à ação. Esta força é produzida por um estado de tensão desconfortável, que existe como resultado de uma necessidade insatisfeita. Todos os indivíduos têm necessidades e desejos. A força inconsciente do indivíduo para reduzir a tensão gerada pela necessidade resulta em um comportamento que ele espera que vá satisfazer as necessidades e, portanto, gerar um estado mais confortável. Para os autores, os motivos não podem facilmente ser inferidos a partir do comportamento do consumidor. Existem três métodos normalmente usados para se identificar e dimensionar os motivos humanos: observação e inferência, relatórios subjetivos e técnicas projetivas. Nenhum desses métodos, afirmam os autores, é completamente confiável em si mesmo. Portanto, em linha com os estudos explorados até o momento, os pesquisadores normalmente usam uma combinação de duas ou três técnicas para avaliar a presença ou a força dos motivos do consumidor.

Entre os pioneiros na aplicação de teorias do inconsciente nas pesquisas de marketing estão Ernest Dichter na década de 1940 e James Vicary na década de 1960. Esses trabalhos precursores definem o que até hoje vem sendo chamado de pesquisa de motivações. A pesquisa psicanalítica, de acordo com Belch e Belch (2008) é criticada por profissionais de 
marketing que a acham vaga, principalmente por não analisar a influência do ambiente externo e, além disso, as conclusões são extraídas sem ampla validação experimental, isto é, com poucos participantes, provocando insegurança para extrapolá-las para o universo do seu público-alvo. No entanto, por ser de natureza qualitativa, traz contribuições importantes ao marketing, por colaborar com a compreensão dos sentimentos dos consumidores. Pode fornecer insights para as agências de publicidade sobre o que os indivíduos pensam.

Segunda etapa: Análise de Percepção

Depois de reconhecer uma necessidade, a etapa seguinte é a busca por informações que contribuam para satisfazê-la. De acordo com Kandel et al (2000), o processo individual pelo qual uma pessoa recebe, seleciona, organiza e interpreta informações para criar uma imagem do mundo que faça sentido é denominado de percepção. Em função das percepções não serem cópias diretas e precisas do mundo real, a sensação naturalmente é uma abstração, e não uma réplica do mesmo. O cérebro não registra simplesmente o mundo externo como uma fotografia tridimensional, mas, sim, constrói uma representação interna dos eventos físicos externos depois de analisá-los em suas partes componentes.

Os sistemas sensoriais fornecem uma representação interna do mundo exterior. Uma das principais funções dessa representação é a de guiar os movimentos que compõem o repertório comportamental (XEREZ, 2005). Fatores internos, personalidade, crenças, experiências, necessidades, motivações e expectativas de um indivíduo influenciam na percepção, que também é afetada pelas características dos estímulos e o contexto no qual os mesmos ocorrem. A percepção deve ser vista como um processo seletivo e individual que filtra o que é recebido, processando e interpretando as informações com influência de fatores internos e externos.

O esforço inicial geralmente é proveniente de uma busca interna, na tentativa de encontrar informações armazenadas na memória, lembranças de experiências anteriores e o conhecimento existente sobre as alternativas de marca, produto ou serviço que facilitem o recall (KOTLER; ARMSTRONG, 2008). A memória é entendida como os eventos mentais e conhecimentos utilizados no reconhecimento de um objeto, na lembrança de um nome, quando se tem ideia, quando se entende uma sentença ou se resolve um problema; são os 
processos de adquirir e reter informação para busca futura ou um processo de arquivamento de informação que permita a realização desses processos futuros (ASCRAFT, 2002).

Terceira etapa: Análise da Atitude

De acordo com Belch e Belch (2008) atitudes são predisposições aprendidas para responder a um objeto. Para os autores estudar as atitudes é fundamental para o marketing, pois estas resumem a avaliação do consumidor sobre um produto, marca ou empresa e representam sentimentos favoráveis ou desfavoráveis a elas, assim como suas tendências comportamentais que facilitam o processo de escolha.

Como definido por Katz (1960) atitude serve para organizar e simplificar as experiências pessoais. $\mathrm{O}$ autor propôs funções adicionais às atitudes como a motivação. Este é o elemento subjacente à formação da atitude e representa a recompensa interna procurada pelo indivíduo. Ele enumera cinco motivações resultantes do agrupamento de atitudes: utilitarista, egodefensivo, valor, conhecimento e social. Cada função pode oferecer contribuições motivacionais independentes para a formação da atitude de um indivíduo, mas a mesma é formada por uma combinação de tais funções.

Em linha com esse pensamento Eagly e Chaiken (1993) afirmam que atitude é uma tendência psicológica que se expressa através da avaliação de uma entidade particular com algum grau de favor ou desfavor e que servem para motivar comportamento e para exercer seleção no processo das informações, seja na percepção ou na recuperação das informações. Devido a importância atribuída às atitudes como causas dos fenômenos individuais, tais como comportamento, bem como dos fenômenos sociais, como o conflito social e discriminação, o conceito de atitude tornou-se uma construção fundamental para a maioria dos cientistas sociais.

Quarta etapa: Análise de Integração para o processo de decisão

Depois de captar informações, avaliar as alternativas, o indivíduo integra tudo o que encontrou para julgar e decidir em busca de satisfazer suas necessidades. A decisão de compra no mercado de consumo é o resultado do comportamento do consumidor, onde este avalia as alternativas encontradas, comparando marcas e características de produtos e serviços 
para satisfazer sua necessidade ou desejo de consumo. Os critérios de avaliação podem ser objetivos (preço, garantia, conforto etc.) ou subjetivos (imagem, estilo etc.). A escolha dependerá também do quanto foi assimilado pelo indivíduo da estratégia de branding da marca, isto é, o quanto do diferencial competitivo foi integrado à marca por sua gestão integrada de atividades estratégicas e operacionais e de execução no mercado. Marca para American Marketing Association (AMA, 2008) é definida como um nome, termo, sinal, símbolo ou design, ou uma combinação dessas características, destinada a identificar os produtos ou serviços de um fornecedor e diferenciá-lo de seus concorrentes. No processo de integração, marca é um fator importante, uma vez que por ter conseguido criar e manter no arquivo de memória do indivíduo boas experiências e na avaliação entre alternativas ser predominante, o composto trazido pode facilitar no processo, uma vez que terá maior ressonância que outras propostas concorrentes oriundas do processo de associações fortes, reações positivas e geração de relacionamento e fidelização.

Este processo onde há o reconhecimento de marca para Kotler e Keller (2007) é fundamentalmente chamado de branding. Significa dotar produtos e serviços de poder de uma marca, ou valor agregado (brand equity). Como demonstrado na pirâmide de Brand Equity, o início desta valoração se dá no estabelecimento de uma conscientização profunda e ampla da marca, resultante de várias associações que evoluem passando por níveis de significação, reações positivas e finalmente a fidelidade (Ilustração 6).
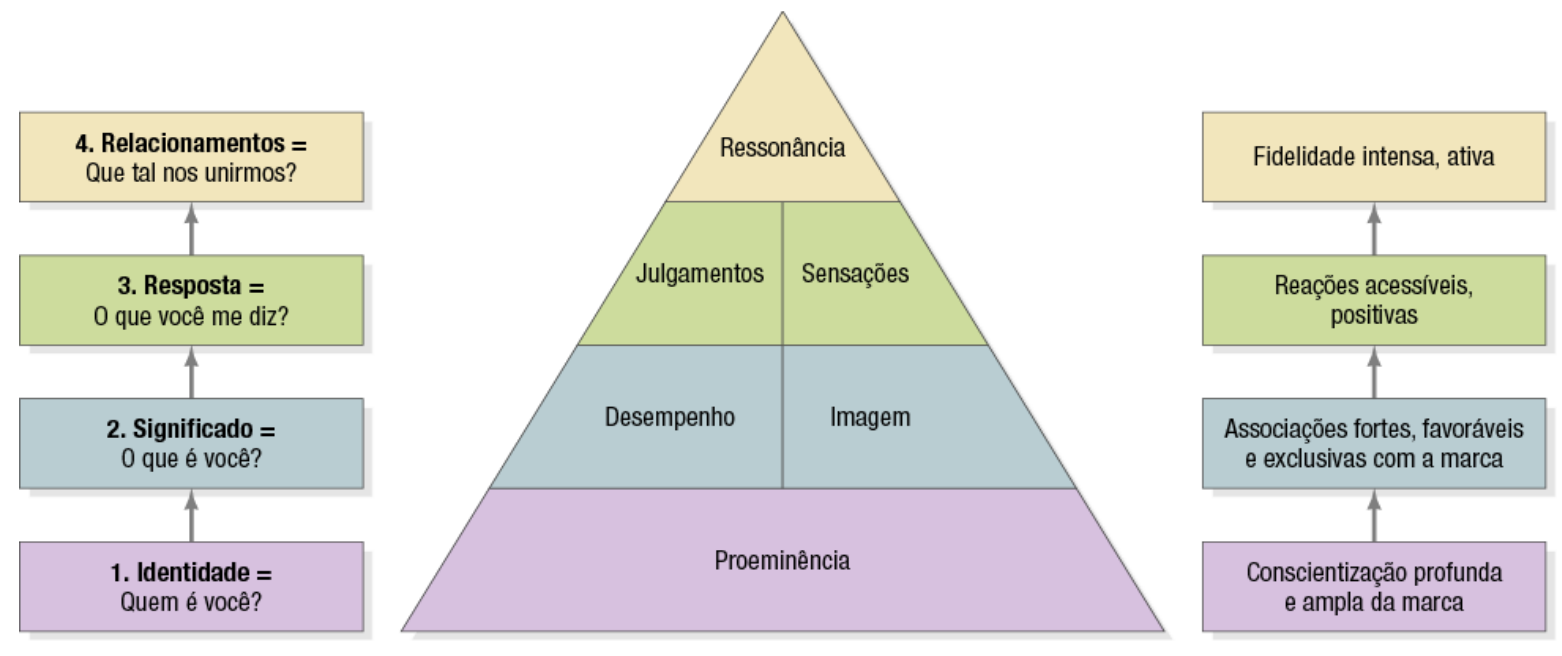

Ilustração 6 - Modelo da pirâmide de brand equity FONTE: ADAPTADO DE KOTLER; KELLER, 2007, p. 275. 
Durante o julgamento, dois subprocessos são importantes na integração e decisão: a primeira fase, onde as informações obtidas são trabalhadas; e a segunda fase, na qual as atitudes dos consumidores são reforçadas ou modificadas.

A decisão, de acordo com Schiffman e Kanuk (1997) é a escolha de uma opção entre duas ou mais alternativas. Em outras palavras, para uma pessoa tomar uma decisão, é preciso que mais de uma alternativa esteja disponível. Na realidade, situações de não escolha de compra ou consumo são razoavelmente raras. Os autores pontuam que nem todas as situações de tomada de decisão do consumidor recebem ou requerem o mesmo grau de procura de informação. Se todas as decisões precisassem de grande esforço, o processo de tomada de decisão do consumidor seria um processo exaustivo, que deixaria pouco tempo para qualquer outra coisa. Por outro lado, se todas as compras fossem rotina, tenderiam a ser monótonas e proporcionariam pouco prazer ou novidade em um continuum de esforço que varie do mais alto ao mais baixo. De acordo com os autores podem ser distinguidos três níveis específicos de processo decisório do consumidor: a solução extensa do problema, a solução limitada do problema e a solução baseada no comportamento de resposta rotineira. A diferença entre os três processos se dá no nível de informação necessária para estabelecer os critérios para julgar as especificidades de sua escolha a serem consideradas. Além disso, há diversas escolas de pensamento que descrevem o processo decisório do consumidor baseado nas diferentes perspectivas de como e por que as pessoas se comportam de determinada maneira. Há a visão econômica, ou aquela onde frequentemente se caracteriza a decisão racional, onde a pessoa está ciente de todas as alternativas disponíveis e é capaz de classificar e identificar a melhor opção entre elas. Há a visão passiva, que descreve o consumidor como basicamente submisso aos interesses próprios e aos esforços promocionais dos profissionais de marketing e, portanto impulsivos e irracionais em suas escolhas. E, por último, a visão cognitiva, onde o consumidor é retratado como um solucionador pensante de problemas, isto é, está à procura de produtos e serviços que preencham suas necessidades e enriqueçam sua vida. Neste modelo há um enfoque do processo pelos quais os consumidores procuram e avaliam informações sobre produtos e processam informações levando à formação de preferência e, por fim, às intenções de compra. Diferentemente da visão econômica, onde o consumidor tenta obter toda a informação disponível, na visão cognitiva o esforço de busca de informação é interrompida quando se percebe que a informação que se tem é suficiente e satisfatória. Como sugere esse ponto de vista, os consumidores frequentemente criam atalhos para as 
regras de decisão ou heurística, para facilitar seu processo decisório e também adotam regras de decisão para enfrentar exposição de grande carga de informação.

O processo de decisão, ou o comportamento em relação a uma decisão, acontece em um processo que envolve simultaneamente emoção, sentimentos e componentes da razão, acredita Castells (2009). O ponto crítico nesse processo é que a emoção, por um lado aciona experiências emocionais relativas ao objeto em questão; por outro lado, pode agir diretamente no processo de decisão levando o assunto para o processo da forma como se sente. Não é que o julgamento se torna irrelevante, mas que as pessoas tendem a selecionar as informações de forma a favorecer a decisão que estão dispostas a dar. Os sinais ou signos se relacionam de uma forma ou de outra, assim, estes sinais são os marcadores somáticos que funcionam como atalhos das emoções e sentimentos para os processos de decisão sem indiretamente processar uma estratégia de pensamento.

De acordo com Batista et al (2008) a decisão sofre influência, pois afeta a vida das pessoas, contribuindo na formação de valores. Assim, está dividida em três linhas gerais: primeiro a influência normativa ou utilitária, que ocorre quando indivíduos, buscando conformidade ou recompensa direta, modificam seus comportamentos e suas crenças para atender às expectativas de determinado grupo evitando uma sanção; depois há a influência por identificação, ou influência por valores que faz o indivíduo aceitar ou internalizar normas, valores, atitudes e comportamentos para suprir sua necessidade de associação psicológica com um grupo, há uma busca por conselhos e opiniões de outros para tomada de decisões; por último existe a influência informacional, que ocorre quando o indivíduo, ao contato com uma nova situação, encontra dificuldade em tomar uma decisão, precisando de recomendações externas do grupo de referência ou de um especialista com fragmentos de informações potencialmente úteis.

A decisão de compra é definida pela escolha do melhor valor dentro das opções possíveis. Os valores dos consumidores, de acordo com Salomon (2002), são coisas que as pessoas acreditam ter a qualidade que lhes são caras e importantes. As pessoas adotam crenças em relação à família, à moralidade e ao tempo de lazer. O estilo de vida de um consumidor (como ele escolhe gastar seu tempo e dinheiro, gostos e valores) se reflete nas escolhas do consumo. 
Para resultar em uma ação é importante o consumidor desenvolver o processo de motivação, percepção, atitude e integração dos dados para decidir em determinada direção. No entanto, há outros itens importantes que influenciam a ação, como: local no qual o produto será adquirido, forma de pagamento e outras questões que precisam ser definidas e avaliadas. Para Belch e Belch (2008) a decisão de compra não representa o consumo efetivo. Geralmente, pode haver um período entre estas duas situações, principalmente quando a compra está relacionada a produtos de alto envolvimento como carros, computadores e outros bens duráveis. Portanto, é importante buscar mais esclarecimentos que facilitem o entendimento do processo que ocorre entre a necessidade, sua percepção e a intenção de compra.

Quinta etapa: Análise do processo de aprendizado

A fase de aprendizado ocorre após ter havido a experimentação do produto ou serviço escolhido dentro do processo de comportamento do consumidor. É nela que consiste a avaliação após o consumo da alternativa final. De acordo com Kotler e Keller (2007) é nesse momento que poderá se manifestar a dissonância cognitiva, o sentimento de que o julgamento pelas opções da escolha foi equivocado devido a escolha não parecer mais ser tão satisfatória quanto foi no momento da compra. De acordo com os autores a satisfação é diretamente proporcional ao desempenho do produto em comparação às expectativas que o indivíduo possuía no momento da aquisição. Por serem as expectativas resultantes de mensagens recebidas de diferentes fontes, inclusive das organizações, a satisfação é algo a ser perseguido e, portanto, as empresas têm que buscar a representação mais próxima ao desempenho do produto em toda sua comunicação, evitando assim a insatisfação ou a dissonância cognitiva.

A repetição da compra acontece caso haja satisfação após a avaliação, porém não é suficiente para que tal repetição aconteça. As organizações têm que, mais que satisfazer, encantar os seus consumidores (OLIVEIRA, 2007).

\subsection{Diferentes contribuições para o estudo do comportamento}

Para Robertson et al (1984) o comportamento do consumidor é estocástico, isto é, somente onde probabilidades podem ser determinadas. De acordo com Oliveira (2007) somente 
imergindo em diversas ciências, por meio de suas contribuições interdisciplinares pode-se desenhar um campo de conhecimento e empregá-lo amplamente. Para a autora, as contribuições das ciências do comportamento a problemas específicos de marketing podem variar em termos de significância de considerável, alguma a pouca. No exemplo a seguir (Quadro 2), relacionado a atitudes e opiniões sobre o mix de comunicação, a psicologia, a psicologia social e a sociologia são as que mais contribuem em significância. Para motivações e comportamento, a psicologia e a psicologia social seriam as maiores contribuintes; já para persuasão a psicologia social ofereceria a maior colaboração.

Quadro 2 - Contribuições das ciências do comportamento a problemas específicos de marketing

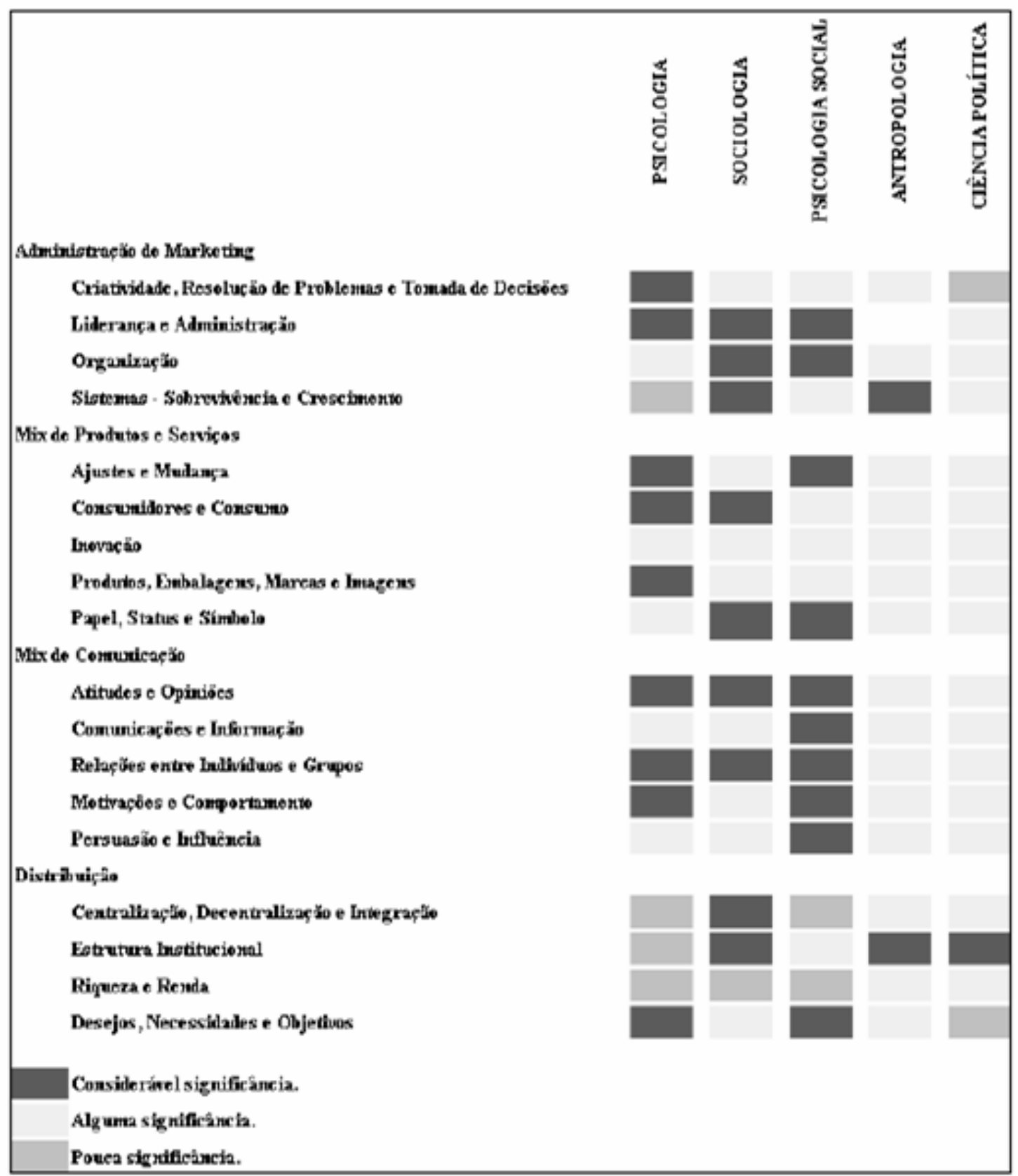

FONTE: OLIVEIRA, 2007, p. 18. 
Em uma proposta mais atualizada descrita por Salomon (2002) é demonstrada a utilização de diferentes disciplinas às questões de pesquisa sobre o comportamento específico no uso de Revistas (Quadro 3):

Quadro 3 - Utilização de diferentes disciplinas e o comportamento

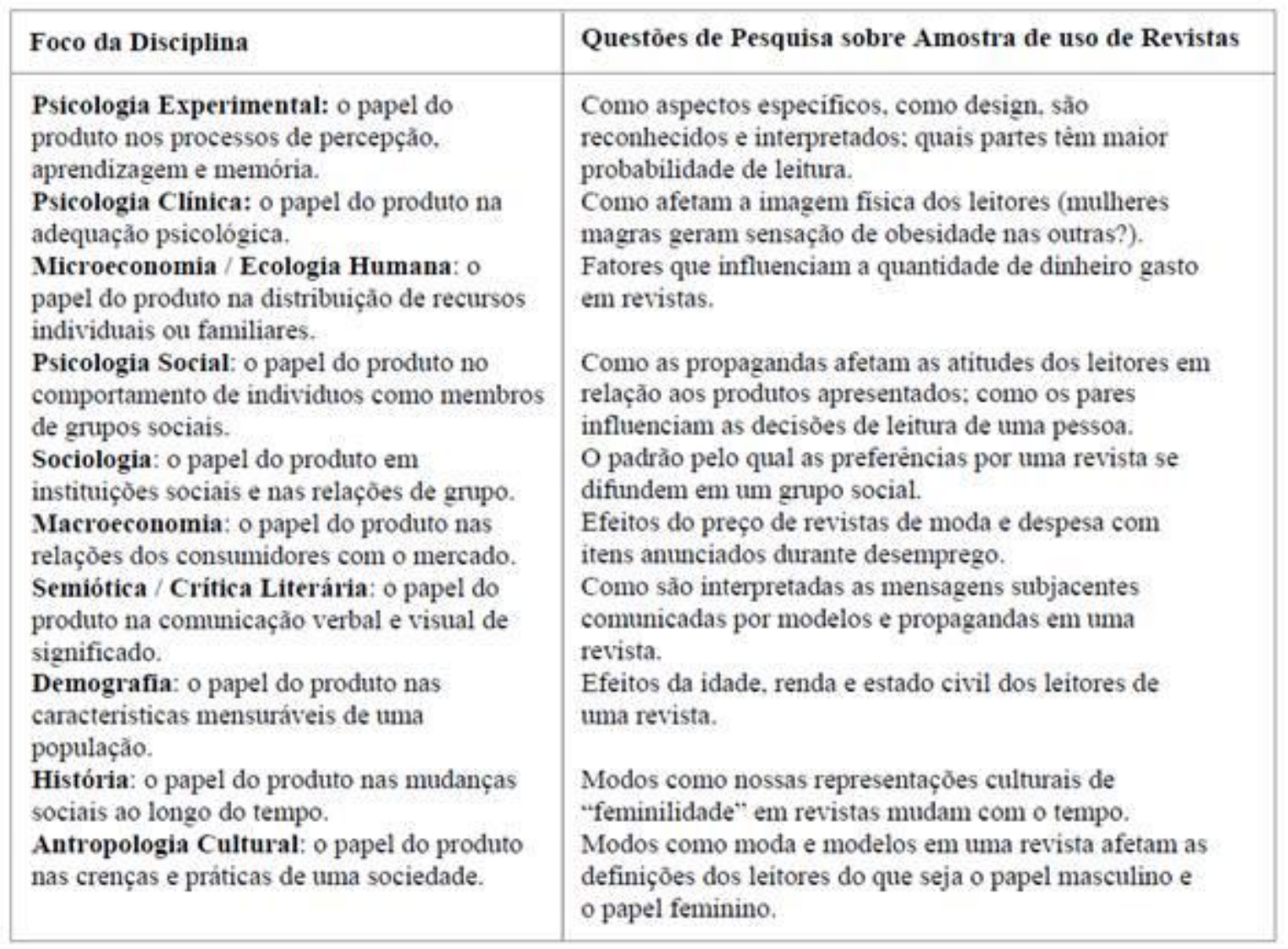

FONTE: ADAPTADO DE SOLOMON, 2002, p. 41.

\section{$1.4 \quad$ Novas perspectivas}

Os estágios do processo de decisão de compra, no qual o consumidor emprega diversos processos mentais para avaliar as alternativas e fazer a escolha para sua necessidade de consumo foram pautados sob uma perspectiva cognitiva. De acordo com Aschcraft (2002) cognição é o processo mental ou a faculdade de conhecer, incluindo aspectos como a sensibilização, percepção, raciocínio e julgamento. O sistema de processamento de informação no processo de cognição é pautado em uma forma inclusiva como ciência cognitiva. Este conceito descreve a cognição como um processo coordenado, frequentemente uma operação paralela de vários processos mentais dentro de um sistema de memória 
múltipla. Desta forma, para o autor, o processo é multidisciplinar, aceitando evidências de todas as ciências interessadas em cognição.

Para Sternberg (2000), processos cognitivos são processos de pensamento e juntamente com as sensações e memórias formam a atenção. Esta é o fenômeno pelo qual processamos ativamente uma quantidade limitada de informações do enorme montante disponível através de nossos sentidos, de nossas memórias armazenadas e de outros processos cognitivos. Tanto leigos quanto psicólogos cognitivos reconhecem que existem pelo menos alguns limites aos nossos recursos mentais, para a quantidade de informações nas quais podemos concentrar esses recursos mentais em qualquer tempo. Os processos cognitivos podem acessar o conhecimento consciente ou pré-consciente - memórias armazenadas que não estamos usando em um dado tempo, mas que poderíamos evocar quando necessário.

Para o autor, as sensações também podem ser atraídas do conhecimento pré-consciente para o consciente. Neste caso, um exemplo é o fenômeno da percepção subliminar, na qual uma pessoa processa mentalmente estímulos específicos sem estar consciente disso. Dentro da percepção subliminar há fenômenos de priming, ou estímulos específicos que ativam rotas mentais que aumentam a capacidade para processar os dados subsequentes. O estímulo é apresentado de forma que não permita seu ingresso no conhecimento consciente com intensidade demasiadamente baixa ou com muita brevidade para ser registrado. $\mathrm{O}$ autor pontua que muitos processos cognitivos podem ser diferenciados em termos de exigirem ou não o controle consciente, sendo os processos que não envolvem consciência chamados de automáticos, pois são realizados como processos paralelos com muitas operações ocorrendo simultaneamente, exigindo pouco ou nenhum esforço ou mesmo intenção. Os controlados, não somente são acessíveis ao controle consciente, mas também o exigem. Estes são realizados em série, sequencialmente, uma etapa de cada vez, e consomem um tempo relativamente longo para sua execução.

Para Batista et al (2008) quando se imagina um estudo sobre percepção subliminar, a maneira mais imediata de realizá-lo é apresentar um estímulo abaixo do limiar de percepção de um indivíduo e medir sua reação relacionada ao conteúdo do estímulo. Um exemplo deste conceito é a experiência realizada por Cheesman e Merrikle (1984). Os pesquisadores apresentavam numa tela o nome de uma cor qualquer e em seguida apresentavam uma cor efetivamente, em um curto tempo de exposição; em seguida, apresentavam um quadro só 
contendo ruídos de imagem para mascarar o estímulo anterior. Após esta exposição, os pesquisadores perguntavam às pessoas quais as palavras e cores que tinham visto, bem como o grau de certeza da resposta. Como o prime aparecia por muito pouco tempo na tela, a maioria dos pesquisados afirmava não ter segurança em sua resposta. Após a análise das respostas, no entanto, para os entrevistados que receberam o prime, pesquisadores chegaram à conclusão que o percentual de acerto era algo em torno de $66 \%$ versus o esperado em torno de $25 \%$. Portanto, o experimento demonstrou um forte indício de que a percepção subliminar existiu. De acordo com Aschcraft (2000) priming é o processo mais fundamental de recuperação da memória e tornou-se uma das áreas mais testadas e discutidas. Priming, para o autor, é definido como a ativação não somente de palavras, mas também de conceitos e ideias que podem expressar vários sentidos juntos.

A psicologia cognitiva se refere a todo o processo pelo qual o input sensorial é transformado, reduzido, elaborado, armazenado, recuperado e utilizado, transformando-se em termos como sensação, percepção, imaginação, retenção, recordação, resolver problemas e pensar. A cognição é um conjunto de processos mentais e atividades utilizadas na percepção, recordação, o pensamento e a compreensão, bem como o ato de usar esses processos. Portanto, faz-se necessário também entender como os consumidores adquirem conhecimento e experiências com produtos e como aplicam essas informações num futuro relacionado a esse consumo. Para Aschcraft (2002) há duas abordagens principais da área cognitiva: a teoria da aprendizagem comportamental ou behaviorism, que enfatiza o papel dos estímulos externos sobre o comportamento, ignorando processos como memória ou atividades mentais; e a teoria da aprendizagem cognitiva (Ilustração 7) apresenta-se como uma evolução de diferentes e conhecidas teorias como a psicologia da Gestalt, de Skinner, acrescidas de linguística, neurociência. Para o autor, de uma forma resumida, o esquema demonstra que a combinação de diferentes linhas de teorias comportamentais engloba diferentes saberes, que por meio de estímulos externos e também da elaboração interna geram o comportamento. 
1990

1960

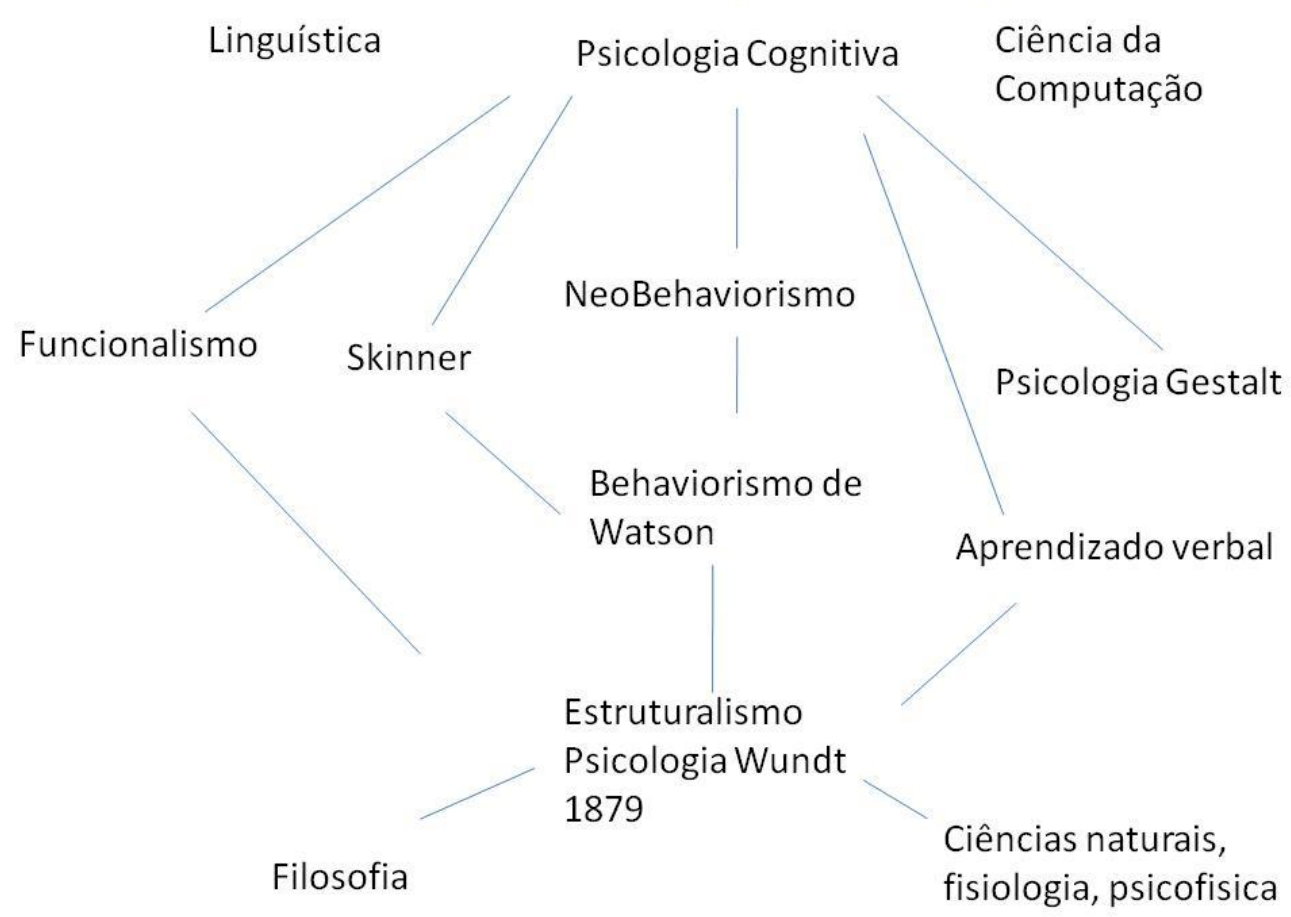

1870

Ilustração 7 - Evolução das teorias comportamentais FONTE: ASCHCRAFT, 2002, p.13

Pela psicologia cognitiva, o autor pontua que há rejeição da visão puramente behaviorista na aplicação em humanos, pois os indivíduos processam ativamente os estímulos do ambiente em torno deles, selecionam parte desse ambiente para processamento futuro, relacionam essas partes selecionadas com informação já armazenada na memória e utilizam o resultado como estímulo mental. Assim, mesmo tendo o condicionamento clássico (behaviorista) presente, o indivíduo interage com algum aspecto do ambiente para que o aprendizado se efetue por meio de uma recompensa ou punição, reforço positivo ou negativo. Há estímulos internos que fazem com que o indivíduo não responda passivamente, com base no condicionamento simples ou reforços dos eventos, e sim produza uma resposta ativa com base no processamento mental dos eventos e suas informações, sejam elas novas ou já armazenadas anteriormente.

Em linha com a teoria cognitiva, para Belch e Belch (2008) o consumidor é influenciado por fatores externos e influências ambientais, que são: cultura (significados aprendidos, valores, regras e costumes compartilhados na vida social); subcultura (baseadas na faixa etária, etnias, 
geografia, religião etc.); classe social (pertencimento a grupos homogêneos de uma sociedade, dentro do qual se compartilham estilos de vida, interesses, comportamentos, valores etc.); grupos de referência (grupos cujos valores são utilizados por um indivíduo como base para suas ações, opiniões e até conduta); determinantes situacionais (situação específica de usos de produto ou serviço, situação de compra e a situação de comunicação). Nessa mesma linha de pensamento, Sternberg (2000) pontua que se usa no processo de tornar compreensível o que se percebe uma combinação da informação proveniente dos receptores sensoriais com conhecimento anterior.

É importante citar que existem estudos com suporte empírico sobre o quanto influências cognitivas vão além das oferecidas pelo ambiente externo, no comportamento de consumo. Mandel e Johnson (2002) demonstram, em um ambiente de compra no comércio eletrônico, que quando há alteração do background da tela em cores e imagens estes antecipam ou utilizam prime, assim aumentam o acesso da informação já existente na memória, e, portanto, há alteração de comportamento de compra. Este resultado se dá tanto com pessoas acostumadas a comprar nesse ambiente quanto com pessoas que estão comprando pela primeira vez.

Outro estudo apresentado por Carlson et al (2006) demonstra a vantagem do líder, isto é, a imagem que se constrói sobre ele tem amplas implicações para a tomada de decisão do consumidor. Nesse estudo a capacidade de segmentar uma marca ou produto através de ordem de suas informações estabelece a possibilidade de um adversário, usando informações de sequenciamento do líder, influenciar a escolha do consumidor em sua direção, aproveitando dos elementos lembrados. Assim, com essas informações os profissionais de marketing têm a vantagem substancial, pois os consumidores não parecem saber que estão tendenciando sua própria avaliação frente a novas informações para apoiar marcas líderes.

Para Kandell et al (2000) a psicologia cognitiva preocupa-se não apenas com a descrição e definição da entrada e saída para um comportamento, mas também com a análise do processo pelo qual a informação sensória é transformada em percepção e ação, com a avaliação de como um estímulo leva a uma resposta comportamental particular. Ao redirecionar a atenção científica para operações mentais complexas, os psicólogos cognitivos focalizaram no processamento da informação, no fluxo da informação sensória a partir dos receptores, até finalmente o seu uso na memória e na ação. A abordagem cognitiva do comportamento 
pressupõe que cada ato motor ou de percepção tem uma representação interna no encéfalo. Visto que o encéfalo é um órgão físico, uma representação interna para os atos motores ou de percepção deve assumir a forma de padrões distintos de atividade neural em grupos específicos de células nervosas interconectadas que codificam o que foi percebido ou a ação. Analisado dessa forma, uma representação interna é uma representação neural: uma representação da atividade neural.

Portanto, basear-se somente em perspectivas de conhecimentos sobre as influências externas constituem uma visão mecânica que não enfatiza os processos individuais e internos dos consumidores, o que justifica o fato da abordagem cognitiva da aprendizagem estar dominando os estudos sobre o comportamento do consumidor nos últimos anos.

\subsection{Mapeamento das técnicas de investigação de comportamento}

Há diversos métodos que podem ser utilizados para realizar uma pesquisa de investigação do comportamento do consumidor. Sua escolha depende do que se deseja atingir, uma vez que cada método fornece uma perspectiva diferente do mundo social, e alguns aspectos do mundo social só podem ser atingidos com um método (SELLTIZ et al, 1960). Os métodos variam de acordo com o objetivo de pesquisa.

De acordo com Ariely e Berns (2010) os profissionais de marketing em sua busca por oferecer a melhor oferta de produto aos clientes podem guiar o processo desde o design e apresentação da proposta, de acordo com as preferências de seu futuro usuário, facilitando o seu processo de escolha. Isso se dá por meio de informação sobre o que é valorizado por seus clientes no processo de busca por um produto ou serviço. A maximização das vendas se dá quanto melhor o cardápio de ofertas, escolhas, preços, comunicação e promoções oferecidas para o consumidor. Na busca por prover as informações para melhor desenvolvimento das propostas, os profissionais podem utilizar uma gama de técnicas de pesquisa de mercado, de focus groups e pesquisas individuais a testes de mercado. $\mathrm{O}$ que se vê é que dependendo do que se pretende explorar: tipo de respostas do cliente, fase do processo de marketing, quantidade de recursos ou técnicas disponíveis pode-se optar por diferentes técnicas, de acordo com o Quadro 4: 
Quadro 4 - Comparação de várias técnicas de marketing

\begin{tabular}{|c|c|c|c|c|}
\hline & Focus Groups & $\begin{array}{l}\text { Questionário de } \\
\text { preferências }\end{array}$ & Simulação & Teste de Mercado \\
\hline Oque é medido & $\begin{array}{l}\text { Respostas abertas, } \\
\text { linguagem corporal e } \\
\text { comportamento: não é } \\
\text { adequado para análise } \\
\text { estatística }\end{array}$ & $\begin{array}{l}\text { Ponderação para vários } \\
\text { atributos de produto }\end{array}$ & Escolha entre produtos & $\begin{array}{l}\text { Decisão para comprae } \\
\text { escolha entre produtos }\end{array}$ \\
\hline $\begin{array}{l}\text { Tipo de processo de } \\
\text { resposta }\end{array}$ & $\begin{array}{l}\text { Especulativa, exceto } \\
\text { quando usada para } \\
\text { acessar protótipos }\end{array}$ & $\begin{array}{l}\text { Oentrevistado deve tentar } \\
\text { ponderar sua decisão } \\
\text { através da introspecção, } \\
\text { em seguida, mapear essas } \\
\text { ponderações na escala de } \\
\text { resposta }\end{array}$ & $\begin{array}{l}\text { Uma escolha hipotética, } \\
\text { do mesmo modo que uma } \\
\text { escolha de compra mas } \\
\text { sem envolver desembolso. }\end{array}$ & $\begin{array}{l}\text { Uma escolha efe tiva, com } \\
\text { clientes utilizando dinheiro } \\
\text { e portanto com escolhas } \\
\text { reais. }\end{array}$ \\
\hline $\begin{array}{l}\text { Uso típico em novos } \\
\text { produtos }\end{array}$ & $\begin{array}{l}\text { No início para ajudar } \\
\text { design de produto, para } \\
\text { testar forma de utilização. }\end{array}$ & $\begin{array}{l}\text { Na fase de design, quando } \\
\text { a escolha é importante }\end{array}$ & $\begin{array}{l}\text { Na fase de design quando } \\
\text { a escolha é importante. } \\
\text { Pode ser utilizado como } \\
\text { ferramenta de previsão. }\end{array}$ & $\begin{array}{l}\text { No fim do processo de } \\
\text { previsão de vendase } \\
\text { medição de resposta para } \\
\text { outros elementos de } \\
\text { marketing como por } \\
\text { exemplo o preço. }\end{array}$ \\
\hline Custose Riscos & $\begin{array}{l}\text { Baixo custo, com risco } \\
\text { quando há má utilização } \\
\text { pelo fornecedor. }\end{array}$ & $\begin{array}{l}\text { Custo moderado e algum } \\
\text { risco de informar a } \\
\text { concorrência. }\end{array}$ & $\begin{array}{l}\text { Custo moderado, mais } \\
\text { alto quando na utilização } \\
\text { de protótipos ao invés de } \\
\text { descriçőes ou conceitos. } \\
\text { Algum risco de alerta aos } \\
\text { concorrentes. }\end{array}$ & $\begin{array}{l}\text { Alto custo e alto risco de } \\
\text { informar concorrência. } \\
\text { Além do risco do produto } \\
\text { ser copiado antes do } \\
\text { lançamento. }\end{array}$ \\
\hline $\begin{array}{l}\text { Habilidade técnica } \\
\text { necessária }\end{array}$ & $\begin{array}{l}\text { Habilidades para } \\
\text { moderação quando do } \\
\text { grupo e habilidades } \\
\text { etnográfica para os } \\
\text { observadores e analistas. }\end{array}$ & $\begin{array}{l}\text { Design de questionário e } \\
\text { análise estatística }\end{array}$ & $\begin{array}{l}\text { Design experimental e } \\
\text { análise estatística, } \\
\text { incluindo modelagem. }\end{array}$ & $\begin{array}{l}\text { Altamente especializado } \\
\text { em teste de mercado ( } \\
\text { observação, coletae } \\
\text { análise de dados) e } \\
\text { ferramentas de previsão. } \\
\text { Altamente especializado. }\end{array}$ \\
\hline Fase de Marketing & $\begin{array}{l}\text { Para entendimento na } \\
\text { elaboração de } \\
\text { conceito/produto } \\
\text { /comunicação. }\end{array}$ & $\begin{array}{l}\text { Escolha de opções entre } \\
\text { conceito/produto/comuni } \\
\text { cação. }\end{array}$ & $\begin{array}{l}\text { Escolha entre opção final } \\
\text { de produto. Fase pré- } \\
\text { lançamento. }\end{array}$ & $\begin{array}{l}\text { Póslançamento de } \\
\text { produto no mercado do } \\
\text { teste e pré lançamento } \\
\text { para expansão para outros } \\
\text { mercados. }\end{array}$ \\
\hline
\end{tabular}

FONTE: ADAPTADO DE ARIELY; BERNS, 2010, p.285

Para se avaliar a contribuição de cada técnica para o entendimento do comportamento pode-se refletir acerca de qual fase do modelo de comportamento de consumo de Schiffman e Kanuk (1997) oferece melhor adequação:

- Focus groups- pesquisa declaratória - fase de input e experiência quando da presença de protótipo em sua avaliação das alternativas

- Questionário de preferência - fase de input e experiência quando da presença de protótipo em sua avaliação das alternativas

- Simulação - fase de output

- Teste de Mercado - fase de output

O que se constata com essa comparação é a oportunidade de avaliação de outras técnicas que possam contribuir principalmente na fase de processo decisório do consumidor, mais especificamente no campo psicológico. Além das propostas de pesquisa de marketing acima 
mencionadas existem outras formas de obtenção de informação sobre os comportamentos, como medições de reações fisiológicas a estímulos de marca ou mesmo técnicas projetivas e semióticas que buscam um entendimento dos símbolos e suas significações para um indivíduo.

Em exemplo recente publicado por Batista et al (2008) para estudos de percepção visual sobre estímulos, pesquisadores se dedicam a explorar como o processo ocorre no ser humano em cenas complexas. Este processo, envolvendo a atenção e a memória, tem, além do que se quer avaliar, estímulos distratores no ambiente no qual o observador se encontra. Para avaliar a percepção e seus prováveis ruídos utilizam-se registros eletrofisiológicos, como eletroencefalograma, outras aparelhagens específicas como eye trackers que capturam onde o olho coloca a atenção na tela do computador, questionários e/ou escalas, reproduzindo em laboratório a cena visual estudada, ou ainda realizando pesquisas em campo, na situação "real" em que a cena ocorre.

Para Santaella e Noth (2005) na obtenção de dados sobre comportamento temos a possibilidade de utilização de diferentes técnicas, sendo aplicação de questionários, técnicas projetivas e semióticas as utilizadas para obtenção de respostas. Observações comportamentais sejam conscientes ou inconscientes como representações mentais podem se utilizar das ciências cognitivas, processos semióticos e neurociência.

Como já mencionado anteriormente por Kandell et al (2000) para um maior entendimento do comportamento a abordagem cognitiva pressupõe que cada ato motor ou de percepção tem uma representação interna na mente. Portanto, dado o interesse da dissertação em explorar o estudo do comportamento em seu sentido de representações mentais, o foco, a partir de agora, será gerar um maior entendimento das possibilidades trazidas pela utilização de diferentes investigações da área cognitiva, desde a semiótica, passando pelas ciências cognitivas e também estudos da neurociência para entendimento do comportamento. 


\subsection{Análise semiótica na busca por representações mentais}

Para Lawes (2003) a semiótica examina na propaganda e em outras ações de comunicação suas cargas simbólicas, trazendo contribuições que podem ser aplicadas ao estudo do consumo e do comportamento, permitindo que as empresas entendam de forma ampla o impacto da comunicação na construção da preferência, podendo administrar estas informações em suas estratégias mercadológicas.

As influências externas são possíveis por meio do processo de percepção, que é a porta de entrada para o conhecimento. Percebe-se algo externo - percepto - é o que diz que o que se percebe é o julgamento perceptivo; é algo que está fora de qualquer um, do controle. Como uma luz que está lá, e mesmo que se fechem os olhos não professa nada, mas quando atinge os sentidos é convertida na forma e de acordo com os limites que os sensores lhe impõem. Força-se sobre cada um e flui internamente e abaixo do nível de deliberação e autocontrole. Tão logo aflui é imediatamente acolhida e absorvida nas malhas dos esquemas interpretativos com que somos dotados. Só percebemos aquilo que estamos equipados para interpretar (SANTAELLA, 2000).

A semiótica está alicerçada na fenomenologia, que vem do grego Phaneron, que quer dizer qualquer coisa que aparece à percepção e à mente e tem por função apresentar as categorias formais e universais dos modos como os fenômenos são apreendidos pela mente. De acordo com Campagno (2009), a semiótica é uma ciência que investiga o sistema de signos e os modos de representação que os humanos usam para transmitir e captar sentimentos, pensamentos, ideias e ideologias. É capaz de descrever as condições nas quais um sentido pode ser produzido ou compreendido, penetrando no mecanismo interno das mensagens.

A origem da palavra signo é latina, com significado do verbo cortar, e a parte representa a coisa maior da qual foi extraída. Signo está no lugar de algo para a ideia que produz ou modifica, é o veículo que comunica à mente algo do exterior, sua interpretação. Aquilo em cujo lugar o signo está é o objeto, aquilo que este signo transmite é seu significado ou meaning. A ideia que ele provoca é seu interpretante (SANTAELLA, 2000). O entendimento da semiótica é iniciado no início do séc. XX a partir de estudos de dois autores, de forma 
paralela, independentes e não comunicantes, quais sejam, o trabalho de Ferdinand de Saussure (1857-1913) linguista suíço e de Charles Sanders Peirce (1839-1914) (ANDRADE, 2009).

A semiologia de Saussure

Rose (2007) sugere que Saussure buscou desenvolver uma forma sistemática de entendimento de como a linguagem funciona, a semiologia, onde o signo é sua unidade básica e é constituído em duas partes. A primeira é o significante, que é um conceito ou objeto, e a segunda parte é o significado, um som ou imagem que está atrelada ao significante. A distinção feita por Saussure é que a relação em particular entre as duas partes não é necessária, é arbitrária, e que o mesmo significante pode ter diferentes sentidos, dependendo da diferença entre um signo particular e outros, e o atual objeto no mundo que o signo se refere é chamado referente. A inspiração saussureana divide-se em duas correntes: a semiótica narrativa do discurso, com grande produção científica, principalmente na academia francesa, e a semiótica da cultura, mais presente na antiga União Soviética.

De acordo com Andrade (2009) como característica comum as duas correntes tem raízes linguísticas e uma abordagem didática, sempre apoiadas em oposições fundamentais entre duas dimensões. Saussure chama de língua um sistema preexistente que está à disposição dos indivíduos para articular suas falas, que sempre serão individuais, peculiares de cada um. Com isso, estabelece como sendo duas as linhas principais do processo de significação linguística: o paradigma envolvendo relações de associações possíveis à disposição de um emissor e a sintagma, eixo de sequência de signos linear que representa a elaboração de um discurso particular.

No entanto, há um debate na semiologia diante da contribuição de Saussure além de sua proposta de signos, pois para o autor signo tinha mais uma noção estática de como operam e não havia interesse em como os significados mudam e são alterados em uso (ROSE, 2007).

A tríade de Peirce

A inspiração peirceana, outro teórico fundamental para a constituição da teoria semiótica e seu propósito de estudo da linguagem como sistema e instrumento de constituição da cognição humana, ocupa-se dos estudos dos signos e das significações em geral, compreendendo todas as formas de expressão com potência significante, o que amplia seu 
alcance para uma dimensão supralinguística. Portanto, vários autores citados por Rose (2007) preferem voltar sua atenção à proposta de Peirce, que desenvolveu uma lógica universal fundamentada na teoria geral dos signos e conseguiu levar a noção de signo mais longe. Para o autor, o signo não precisa ter a natureza plena de uma linguagem (palavras, desenhos, diagramas, fotos), mas pode ser uma mera ação ou reação, ou ainda qualquer sentimento mais indefinido do que uma emoção. Qualquer coisa que esteja presente à mente tem a natureza de um signo.

Signo é aquilo que dá corpo ao pensamento, às emoções, reações. Qualquer coisa pode ser analisada semioticamente com a teoria de Peirce. A tríade proposta por ele envolve um relacionamento ou uma interação dinâmica entre o signo (qualquer coisa que age como preparatório ao estímulo), um designatum (o objeto ao qual o signo se refere) e o interpretante (o efeito no intérprete, a disposição do intérprete à resposta), conforme a Ilustração 8; a relação do signo com designatum ou objeto enquanto relação semiótica. Esta pode ser exemplificada com a fumaça como signo de fogo, independentemente de essa relação existir também diadicamente (como uma relação de efeito e causa), a referência ao futuro num terceiro elemento, interpretante, é essencial. Não importa se a terceiridade é real aqui e agora ou se ela é apenas virtual e a espera de se realizar (DEELY, 1990).

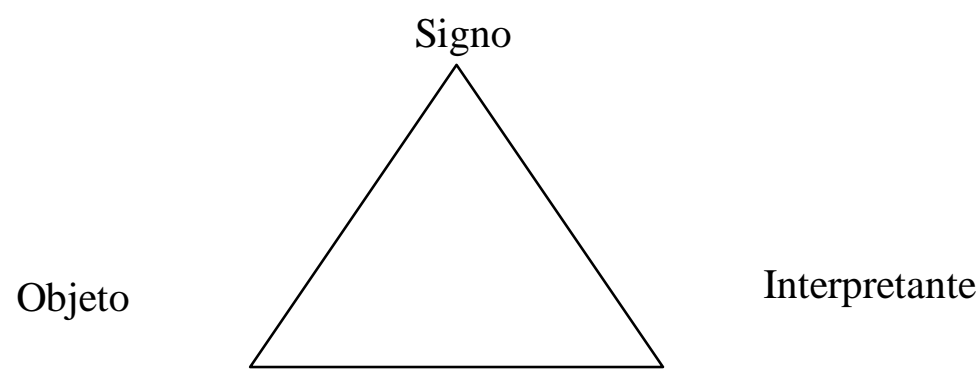

Ilustração 8 - Formulação Pierciana

A teoria dos signos é parte da semiótica desenvolvida por Peirce que será estudada por promover definições, classificações para análises de todos os tipos de linguagem, signos, sinais, códigos de qualquer espécie. A proposta peirceana rompe com a visão tradicional, ao propor uma concepção triádica do processo de conhecimento. A peculiaridade de tal concepção está no dinamismo que confere à consciência, no desenvolvimento daquele processo (Ilustração 6). Com a noção peirceana de signo, as formas do passado, presente e futuro apresentam-se em contínua interação, resultando num movimento criativo, cujo produto quase sempre não se esgota numa única relação, mas se abre a possibilidades 
infinitas. Essa concepção aplicada ao processo de conhecimento, evita todo tipo de individualismo que, porventura, possa dominar o âmbito do pensamento. Este último, por constituir-se de signos, mostra-se predominantemente social, pois ao projetar-se no futuro, o pensamento retoma o passado, universo da tradição, reproduzindo outro pensamento mais desenvolvido no futuro (SANTAELLA, 2000; ANDRADE, 2009; CAMPAGNO, 2009).

Para Peirce, (CP 1, 540 apud SANTAELLA; NÖTH, 2005, p. 17), representação é o processo de apresentação de um objeto a um intérprete de um signo ou a relação signo objeto: "eu restrinjo a palavra representação à operação do signo ou a sua relação com o objeto para o interpretante da representação.”

Como exemplo, o autor cita que uma palavra representa algo para a concepção da mente de um ouvinte assim como um retrato representa a pessoa para quem ele dirige a concepção de reconhecimento. De acordo com Pierce e descrito na Ilustração 9, o signo pode ser classificado em três diferentes formas: por sua semelhança, sua indicação ou por seu caráter de lei ou convenção. Este sugere ou tem uma relação com o objeto de descrevê-lo, designá-lo ou simbolizá-lo. O efeito deste signo na mente do interpretante se dá de maneira imediata - o potencial dele, mesmo que não exista interpretante; ou se dá de forma dinâmica - que é o efeito em um intérprete. Os efeitos podem ser emocionais, energéticos ou lógicos em virtude da ideia que gera na mente através do símbolo.

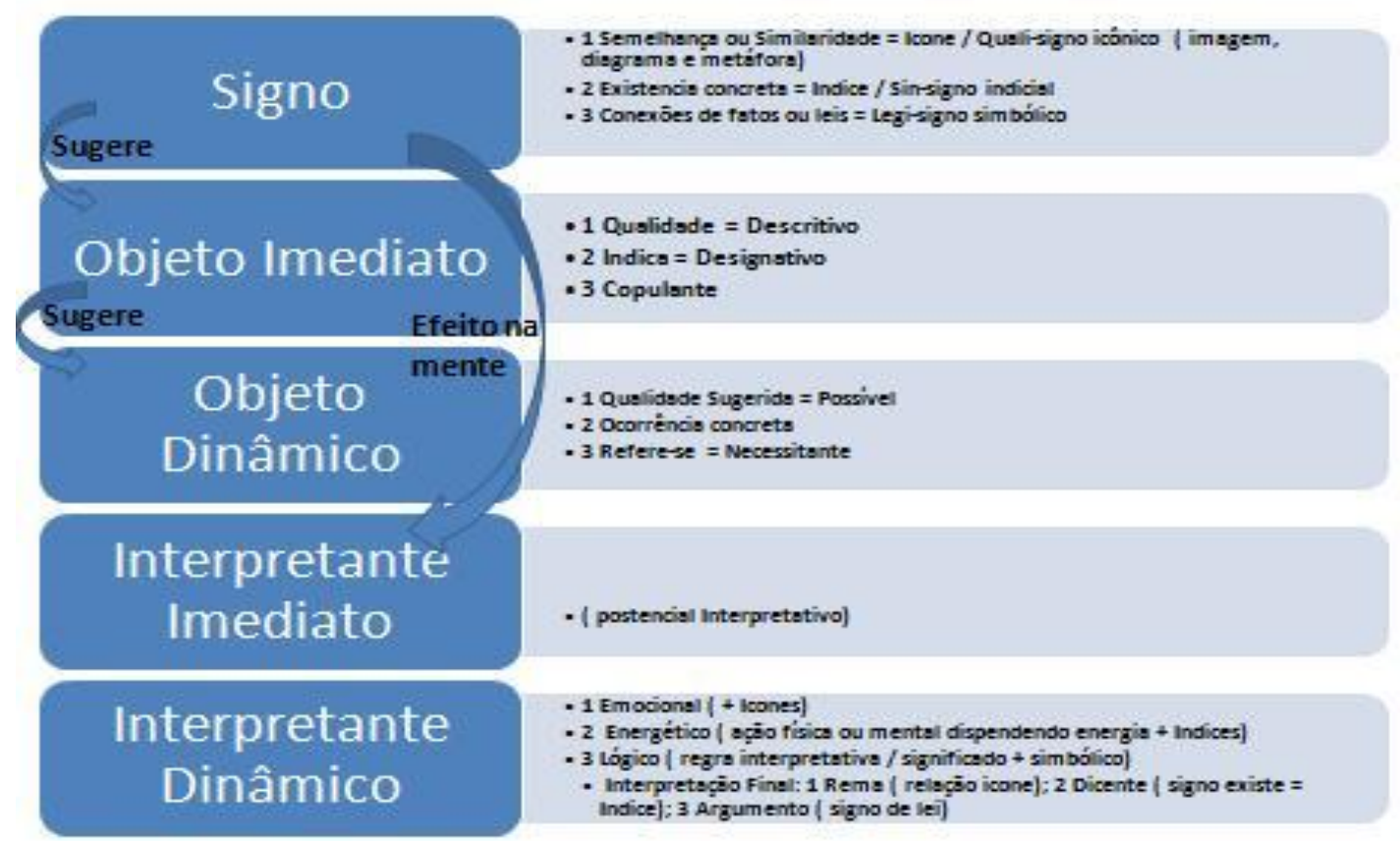

Ilustração 9 - Resumo da teoria do Signo de Peirce 
Diante de um processo semiótico dos signos, em primeiro lugar deve-se contemplar, ou, como dizem Santaella e Nöth (2005), tornar-se possível para o que está diante dos sentidos, deve-se dar aos signos tempo para eles se mostrarem. Depois disso o segundo tipo de olhar é o observacional, onde a capacidade perceptiva entra em ação e há capacitação para discriminar, distinguir a parte do todo, corporificar para depois disso generalizar em correspondências da primeiridade, secundidade e terceiridade. Depois de analisado o signo, deve ser analisada sua relação com o objeto; o objeto imediato antecede o dinâmico e depois disso a relação com o interpretante. É apenas nesse ponto que o signo age como signo.

Um exemplo de uma análise de signos que são as formas mais influentes na sociedade capitalista é a propaganda. Sua presença é ubíqua e, portanto, parece autônoma, um tipo de realidade independente que se conecta com nossa vida. E, por sua presença ser tão penetrante e nossa leitura dela tão rotineira, tende-se que a propaganda funciona transferindo ou tentando transferir significados visuais e textuais para produtos e marcas de modo persuasivo a ponto de certos objetos tornarem-se o objetivo correlato de certas qualidades (ROSE, 2007).

Para Lawes (2003) a semiótica é diferente das investigações qualitativas tradicionais, que normalmente tem uma perspectiva de interpretação do respondente de dentro para fora, isto é, entrevistas e grupos são orientados para a obtenção de fenômenos psicológicos, tais como percepções, atitudes e crenças de dentro da cabeça das pessoas. Semiótica tem uma abordagem de "fora para dentro". Ela pergunta como essas coisas entram na cabeça das pessoas, de onde vem. A crença é que os significados vêm da cultura do meio onde vivem, como se comunicam com seu grupo, conscientemente ou não, através de formas como linguagem, imagens visuais e música. O que a semiótica agrega é uma ferramenta customizada para entender embalagens, propaganda e todos os tipos da literatura de marketing, inclusive espaços tridimensionais como lojas de varejo. Semiótica é uma ferramenta relevante de investigação, pois pode interpretar as regras culturais ocultas ou códigos que sustentam as comunicações contemporâneas e determinam como as pessoas percebem as outras coisas do entorno. Pode ser útil estrategicamente para entender e replicar o segredo das estratégias de comunicações exitosas ou para criar ou produzir publicidade ou embalagem de acordo com uma proposição de marca estabelecida.

Um exemplo onde uma propaganda depende de signos humanos para simbolizar qualidades de sua audiência é mostrado na análise da comunicação da marca Halifax (Ilustração 10), 
marca que oferece serviço de hipoteca para compra de casa nos Estados Unidos. Nela vemos a seguinte interpretação com foco nas mãos como signo:

O anel é referência de casamento, e na foto a mão do homem representa - promessa, confiança, segurança. As fotos são ilustrações clichê. Mas o ponto da comunicação é minar a confiança e segurança oferecida pelo homem... O clichê da segurança masculina e a promessa são expostos para mostrar a necessidade de Halifax. Ainda, simultaneamente, a imagem, a mão, o anel, mina a ligação literal de casamento como segurança, é usada, sobretudo como clichê para representar a promessa, segurança e confiança oferecida em reparação por Halifax. Em outras palavras, segurança, representada pela mão (significante), se transforma em significado e sua ausência, a necessidade de Halifax; que retorna então ao seu status original de significante através de seu conduto produto (WILLIAMSON, 1978, apud ROSE, 2007).

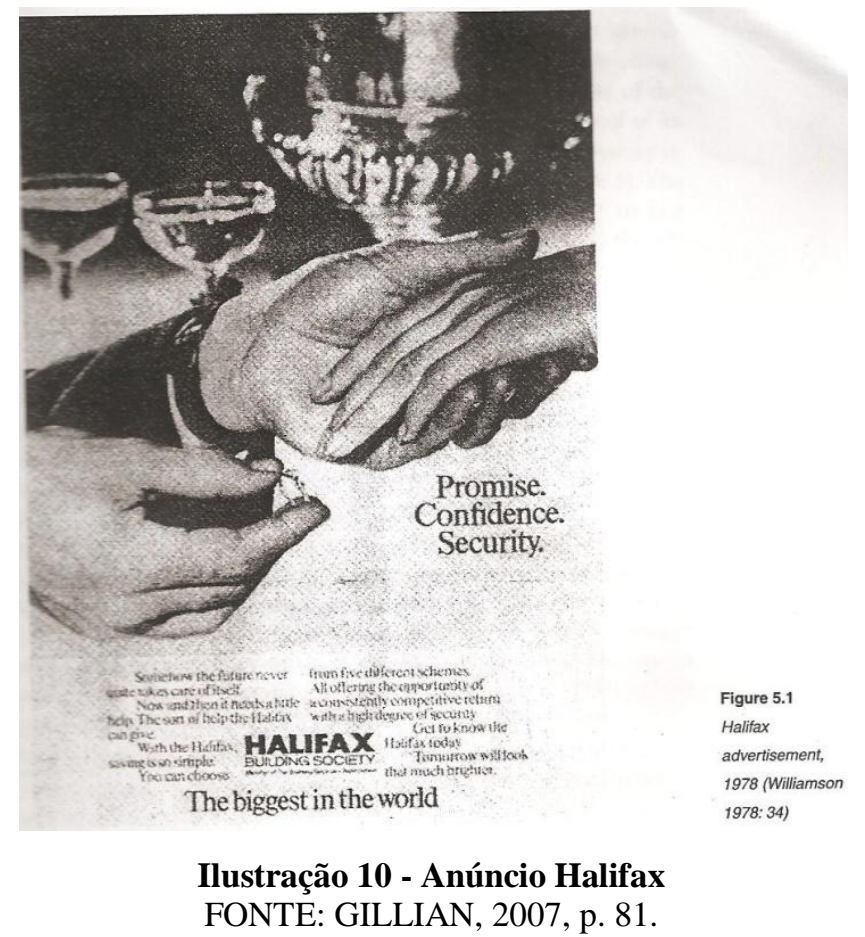

Para Lawes (2003) um projeto de semiótica tem tipicamente duas fases. A primeira inicia-se com um brainstorming, uma seção onde uma associação livre com o tema a ser estudado é iniciada, como: definição do objeto, quem o utiliza, o que acontece com ele, qual é o ambiente onde ele se insere. Para cada resposta é associado algo que passe pela mente como música, piada, programas de televisão, shows, assuntos na mídia, experiências pessoais. Este banco de associações é então agrupado em temas com ideias em comum e realiza-se uma busca em evidências culturais que existam para esses temas, quais existem na cultura atual de forma proeminente. A segunda fase do processo de pesquisa é quando o material recolhido é analisado e a semiótica pode trazer uma técnica que possui ferramentas para desvendar e trazer o sentido para o que foi encontrado. As técnicas ajudam o pensamento organizado e também a identificar as similaridades e diferenças nas informações dentro de uma categoria 
ou setor. O kit de ferramentas é formado dos seguintes materiais: signos visuais, signos linguísticos, signos auditivos, situações implícitas da comunicação, estrutura textual, estrutura de informações, ênfase visual, oposições binárias e pares opostos, códigos de comunicação.

Para o autor, a semiótica está preocupada principalmente com a recepção da imagem pela audiência, em fazer sentido para quem a vê. Assim, deve oferecer uma posição particular para seu expectador, deve implicar em ausências que convidem o expectador a preencher, o texto escrito deve atrair a atenção por ausência de algo, possuir trocadilhos ou quebra-cabeças, ou ainda caligrafia, onde o produto é transformado em uma palavra que representa o objeto real. Ela pode ser usada de duas maneiras: em conjunto com um método qualitativo com grupos de entrevistados, precedendo os mesmos para levantamento de hipóteses a serem confirmadas e refinadas com os consumidores de acordo com os objetivos desejados; pode ser usada também após o grupo qualitativo para ajudar a analisar os resultados do grupo. Os métodos semióticos podem esclarecer como os códigos utilizados em propaganda em uma categoria estão mudando e ajudar a mantê-los relevantes e atuais. Pode também revelar interessantes técnicas que estão sendo utilizadas por concorrentes e ajudar a visualizar o futuro, bem como entender o passado, uma vez que interpreta a cultura e suas mudanças, coisa que o método qualitativo, através de resposta dos consumidores, dificilmente conseguirá contribuir.

Para Santaella e Noth (2005) a semiótica é a teoria de todos os tipos de signos, códigos, sinais e linguagens, portanto temas de representação mental e processos perceptivos que nos levam da semiótica à área da ciência cognitiva. Esta desenvolve modelos de conhecimento e, portanto, representações e modelos de processamento de suas estruturas em processos mentais, ou modelos de processos cognitivos.

Aprofundando esta análise, para Castells (2009) metáforas ou signos são críticos para conectar linguagem e comunicação e circuito neural. É através de metáforas que as narrativas são construídas e estas são compostas por quadros ou frames, que são a estrutura da narrativa, são as metáforas que correspondem às estruturas do cérebro que resultam no tempo em atividades neurais. A comunicação acontece com a ativação da mente para dividir significado. A mente é um processo de criação e manipulação de imagens (mentais ou não) do cérebro. Ideias podem ser vistas como arranjos de imagens mentais. E, com toda probabilidade, correspondem a padrões neurais. 
O esperado de um estudo semiótico para Lawes (2003) é o aprofundamento de aspectos de conteúdo, da intenção do emissor na elaboração da mensagem e sua recepção. No entanto, uma análise semiótica pode apresentar problemas inerentes ao método e, portanto, uma probabilidade de erro na interpretação pela falta de unidade conceitual em sua utilização e interpretação, pois cada estudo tem seus próprios termos analíticos. Além disso, o método semiótico apresenta uma alta dependência da habilidade do analista individual, o que pode vir a comprometer a consistência e a confiabilidade da análise. O método também apresenta uma dificuldade de quantificação dos resultados pela utilização de características subjetivas e ausência de objetividade e a impossibilidade de aplicar técnicas padronizadas a todos os tipos de mensagem, uma vez que essas se dão em diferentes formatações dificultando certos modelos analíticos (ANDRADE, 2009). Desta forma, apesar da inegável contribuição para estudos de marca, a semiótica nem sempre oferece um ferramental teórico que possa transformar-se em normas, apresentando-se muito mais como uma abordagem subjetiva.

De acordo com Ashcraft (2002), uma das características centrais das investigações cognitivas modernas é a sua fidelidade a métodos objetivos e empíricos de investigação, e esse é o foco da dissertação nas próximas seções.

\section{A contribuição da ciência cognitiva para o estudo do comportamento}

Para Ashcraft (2002) a ciência cognitiva é tida como o estudo do pensamento humano, usando todas as técnicas científicas disponíveis e incluindo todas as disciplinas relevantes para explorar e investigar a cognição. Portanto, grande parte da nova abordagem oriunda da ciência cognitiva é de natureza multidisciplinar, sua forma de ser aberta a ideias e descobertas de outras áreas mais tradicionais de pesquisa. Esta nova ciência é entendida como uma evolução ou revolução da área da psicologia cognitiva, uma vez que traz a contribuição de uma investigação da mente, seus processos, de forma cientificamente comprovada. De acordo com essa teoria são quatro as formas de medição usadas pelas ciências cognitivas: o tempo de duração de determinada tarefa, a exatidão de seu desempenho, os relatos verbais e as evidências de processos da neurociência oriundas de resultados de técnicas de eletroencefalograma e ressonância magnética. O termo cognição se refere a todos os processos pelos quais a entrada sensorial é transformada, reduzida, elaborada, armazenada, 
recuperada e utilizada. Há duas importantes lições do estudo da área cognitiva até agora. Primeiro, os processos mentais podem ocorrer com muito pouca consciência. Isso é especialmente ou apenas verdadeiro em processos que tenham recebido uma grande quantidade de prática, como habilidades de leitura. Segundo, mesmo que estes processos possam operar muito rapidamente, eles são bastante complexos, envolvendo áreas motora, perceptiva e mental para a realização de uma ação.

A ciência cognitiva para Xerez (2005) relaciona-se de alguma forma com o estudo de significação porque é pela linguagem que se estruturam pensamento, memória, além de permitir a interação e a forma de expressão pessoal. Esta área está sendo considerada a moderna ciência da mente, ao fundir a psicologia cognitiva com a ciência neural (ciência do cérebro). O principal objetivo da ciência neural cognitiva é examinar, em termos biológicos celulares, incluindo anatomia do cérebro, sua estrutura funcional, arquitetura e seus princípios de funcionamento, todas as questões clássicas, filosóficas e psicológicas acerca das funções mentais. Em outras palavras, estudar as representações internas dos eventos mentais.

Um exemplo de uma avaliação cognitiva simples é o teste IAT ou ITA (teste de associação implícita). De acordo com Brunel et al (2003) o IAT tem sido utilizado para mensurar várias avaliações: atitudes aos produtos e seus constructos em psicologia social; associações em geral a certas representações de marca; relação entre marca e seus conceitos, comunicação. Ele mede não a origem das associações, mas sim seus efeitos individuais e também universais de estímulos familiares em casos que tenham somente duas opções de respostas, oferecendo resposta e associações comparativas entre opções. Por basear-se em respostas binárias é um teste simples e muito efetivo quando da avaliação de elementos básicos de referência como: raça, cor de pele, sexo, nacionalidade, peso, gênero. Ele é validado e realizado em diversas nacionalidades. Existem hoje vários testes disponíveis para demonstração IAT, que podem encontrados do site da Universidade de Yale (https://implicit.harvard.edu/implicit/). No Brasil existem inúmeros testes disponíveis, alguns deles mencionados na Ilustração 11: 


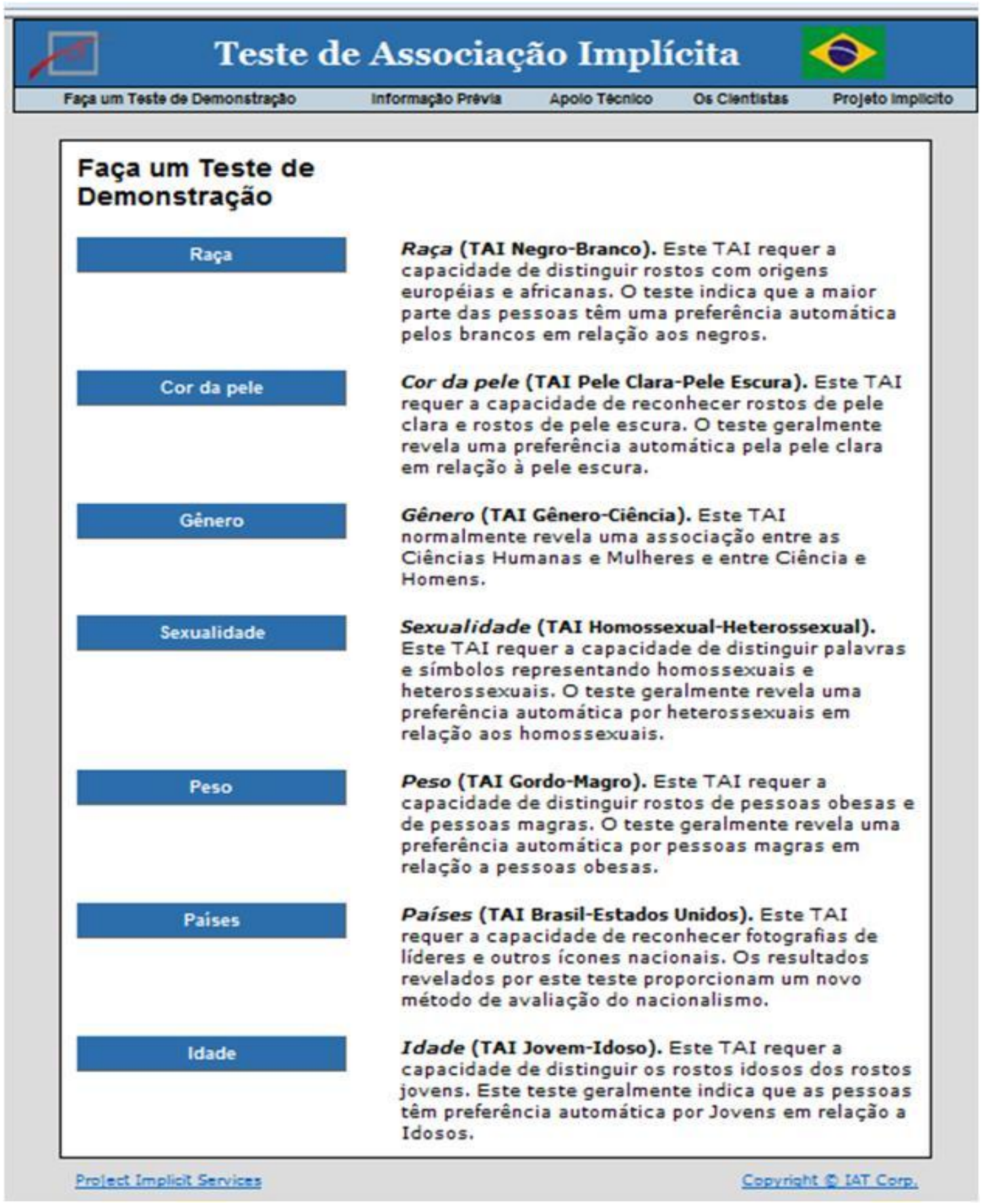

Ilustração 11- Testes disponíveis ITA

FONTE: SITE DA UNIVERSIDADE DE YALE (https://implicit.harvard.edu/implicit/).

O IAT mensura o grau no qual grupos específicos são associados automaticamente a mensurações positivas ou negativas. O teste foi formalmente introduzido por Greenwald et al (1998) e obteve rápido reconhecimento, transformando-se na mais conhecida forma de mensurar associações implícitas em psicologia. Um exemplo é o caso estudado sobre diferentes associações a raças pelos autores que originaram o teste. Há respostas incontroláveis e indiretas que exibem preferências, ou avaliações positivas para um grupo 
quando em comparação com outro, elemento conhecido coloquialmente como racial bias que implica em uma ação consciente de discriminação aprendida culturalmente sobre os grupos. No entanto, estudos posteriores feitos com o apoio da neurociência, com a utilização do fMRI, conseguiram medir a avaliação racial na ativação da amídala, parte do cérebro responsável pelas áreas de aprendizado, memória e avaliações, demonstrando que há uma forte e inconsciente reação negativa para negros em comparação com o grupo social de brancos, resultante de um aprendizado geral. Essa reação muda quando esse grupo passa a ser familiar e bem avaliado, de acordo com Phelps et al (2000), pois em sua demonstração o que fica evidente é que, apesar da resposta inconsciente da amídala, há uma aquisição de conhecimento e experiência individual capaz de modificar a informação e provocar ações conscientes em relação à raça, resultantes de outros mecanismos cerebrais. Os autores, no entanto, sugerem que os influenciadores que predizem as reações (comportamento e cérebro) devem incluir os conhecimentos adquiridos dos grupos culturalmente e socialmente envolvidos nas experiências individuais e seus grupos de relacionamento. Resultado parecido foi encontrado em Cunningham et al (2004) onde a ativação neural é modificada de seu automático em situações de controle social; no estudo evidenciou-se que a ativação automática da amídala, por pouco tempo, a faces de pessoas negras foi maior que para faces de pessoas brancas. No entanto, o resultado encontrado é modificado em local de ativação uma vez que o tempo de exposição é aumentado, direcionando-se para regiões do córtex associadas ao controle. $\mathrm{O}$ estudo fortalece a ideia de que há mudança de ativação neural em regiões distintas com mesmo estímulo dependendo do tempo de exposição, mostrando as diferenças entre processos automáticos versus controlados.

Para Kandel et al (2000) a última fronteira das ciências biológicas é entender a base biológica da consciência, os processos mentais pelos quais percebemos, agimos, aprendemos e lembramos algum fato. A capacidade de sequenciar os genes revelou o plano geral para o funcionamento das células. O próximo passo, mais desafiador, é a unificação do estudo do comportamento, a ciência da mente, e a neurociência - a ciência do sistema nervoso. Tal abordagem baseia-se na noção de que todo comportamento é resultado da função neural. Mente é o conjunto de operações realizadas pelo sistema nervoso, que podem ser motores simples até as ações cognitivas complexas, ou seja, todos os distúrbios comportamentais que caracterizam as doenças psiquiátricas de afeto (sentimentos) ou da cognição (pensamentos) são distúrbios da função do sistema nervoso. As operações neurais, responsáveis por nossas habilidades cognitivas, ocorrem basicamente no córtex cerebral, no entanto a leitura, a 
audição e o ato de pensar sobre o significado de uma palavra ativa áreas diferentes. $\mathrm{O}$ processamento da informação requer muitas áreas encefálicas individuais, que são interconectadas de maneira apropriada. A tarefa da neurociência, de acordo com os autores, é explicar o comportamento em termos das atividades neurais.

A ciência cognitiva para Santaella e Noth (2005) estuda até o momento principalmente a representação da informação linguística e visual. De acordo com esse pensamento, existem até hoje quatro modelos que desenvolvem a forma da nossa representação mental: 1) como ideias, modelo mental das coisas que tem em comum com estas a forma; 2) como imagens, modelos imagéticos de representação analógica; 3) como símbolos, até linguagem e principalmente conceitos abstratos são representados mentalmente na forma de símbolos; 4) como estados neurofisiológicos.

Para Lakoff (2008) os neurocientistas dizem que neurônios, quando ativados, disparam formam redes e se conectam. Como o mesmo circuito é ativado dia após dia, a sinapse (ou conexões) dos neurônios do circuito fortalecem-se até que um circuito permanente é estabelecido. Isso é chamado recrutamento neural. Recrutamento é o processo de fortalecimento de sinapses durante o processo de criar um caminho, dentro dos quais ativações fortes podem fluir. Quanto mais neurônios são usados mais fortes se tornam. Este fortalecimento é um aumento físico do número de receptores e retransmissores das sinapses. Tal recrutamento fisicamente contribui para a metáfora ou a formação de significado. Portanto, tanto metaforicamente quanto fisicamente o aumento de conexões fortalece as conexões. Metáforas simples podem, portanto combinar-se e se vincular por meio de neurônios para formarem metáforas mais complexas.

Winkielmanand e Berridge (2003) demonstram os benefícios da colaboração entre cientistas sociais e cognitivos e neurocientistas para ajudar no entendimento das atitudes. Estudos realizados na década de 1970 demonstram que repetição com a utilização de outdoor, mídia, slogans é uma das técnicas efetivas para marcas influenciarem atitudes positivas, mas não é a única. São várias as formas de facilitar o processamento de informações cerebrais. Outros estímulos como som, logos, também facilitam a percepção, decodificação, interpretação, memorização e expressão e, portanto, fazem com que o elemento em questão seja mais facilmente percebido e esteja mais propenso a obter uma resposta efetivamente positiva em relação a algo. Como resultado, os indivíduos podem experimentar uma reação positiva e 
afetiva sem, no entanto, estarem conscientes da verdadeira fonte da reação. Os eleitores podem erroneamente atribuir esta reação à mensagem, reforçando a sua avaliação por razões que nada têm a ver com o conteúdo real que a influenciou. Algumas manifestações deste processo existem no domínio do consumidor.

O modelo mental baseado em estados neurofisiológicos tem duas linhas interpretativas, a primeira linha é defendida pelo conexionismo, que descreve o aspecto cognitivo pela interpretação dos processos de transmissão de impulsos eletroquímicos entre neurônios, através de sinapses ligando redes neurais. Os neurocientistas estão convictos de que para compreender como as pessoas pensam, comportam-se, sentem, agem e se relacionam umas com as outras, é essencial entender como eventos em células individuais levam à cognição (SANTAELLA; NÖTH, 2005; ASCHCRAFT, 2002; XEREZ, 2005). Como exemplo do conexionismo o que se vê na Ilustração 12 é denominado “efeito Reicher-Wheeler”, em que é observado um paradigma experimental conhecido como tarefa de decisão léxica. Nesse paradigma é apresentada uma série de letras de forma muito breve; na sequência é então removida ou coberta com uma máscara visual e solicita-se à pessoa que tome uma decisão sobre essa série de letras. No estudo, as pessoas são mais precisas na escolha da letra correta quando apresentada no contexto de uma palavra do que isoladamente, fora do contexto. Até as letras em pseudopalavras impronunciáveis são identificadas com maior precisão dentro do contexto do que as palavras que não ajudam com qualquer identificação. 


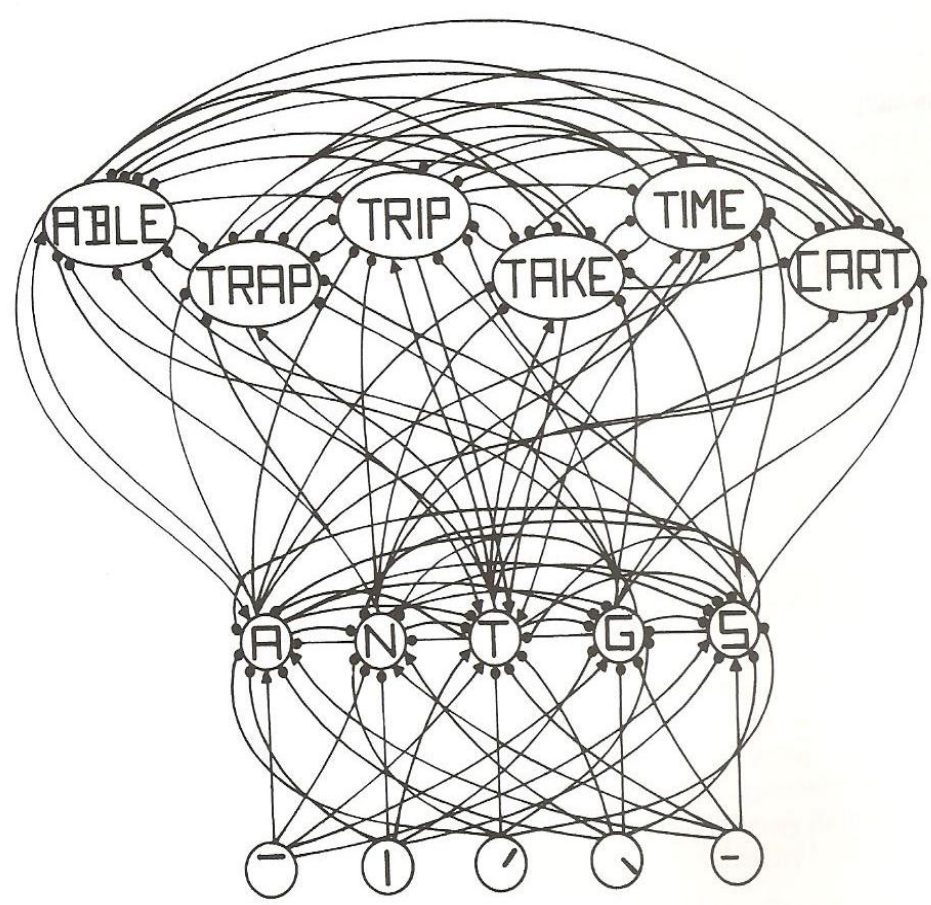

Ilustração 12 - Modelo de ativação interativa do reconhecimento de palavras FONTE: STERNBERG, 2000. p. 138

Para esse fim, de acordo com Kandell et al (2000), os métodos da biologia devem ser combinados com técnicas que relacionam as atividades de populações de neurônios interconectados com o comportamento. A comparação melhor e mais realista é pensar nos processos mentais como várias linhas de trem que desembocam no mesmo terminal. Um problema em uma ligação na via afeta as informações levadas por ela, mas não necessariamente interfere de forma permanente no sistema. As partes restantes do sistema podem sofrer modificações para acomodar o tráfego extra depois do colapso de uma linha. A principal razão da longa demora, para se verificar quais atividades mentais estão localizadas dentro de quais regiões do cérebro, é o fato de estarmos lidando com o mais profundo quebracabeça biológico - o da representação neural da consciência e da autoconsciência. Afinal, para estudar a relação entre um processo mental e a região específica do cérebro, devemos ser capazes de identificar os componentes da atividade que se quer explicar. Contudo, esses processos mais complexos são mais difíceis de serem descritos, medidos objetivamente e dissecados em suas partes e suas operações elementares. Além da anatomia do cérebro ser imensamente complexa, sua estrutura e interconexões não são completamente entendidas. Só na última década uma atividade mental específica, sua representação, bem como os aspectos da atividade e regiões do cérebro tornou-se possível. 
o se combinar ferramentas conceituais da psicologia cognitiva com novas técnicas fisiológicas e acrescidas dos métodos de observação do cérebro por imagem, é que se pode iniciar a visualização das regiões envolvidas em comportamentos especiais e suas operações mentais mais simples. Como exemplo, vale citar os métodos de neuroimagem que podem ser usados para se estudar as atividades de populações de células em animais e em seres humanos durante atividades normais (KANDEL, 2000; SCHWARTZ ; JESSELL, 2000).

A segunda linha interpretativa levantada por Santaella e Nöth (2005) chama-se cognitismo, onde o tratamento das representações mentais acontece na forma de interpretantes sígnicos, na forma de signos icônicos ou simbólicos (ideia, imagem símbolo). Para os modelos abordados pela semiótica entende-se que se existe um mundo material para formação de uma percepção, este também existe no mundo imaterial em complementaridade. O que defendem os mesmos autores é que o mundo das imagens divide-se em dois domínios: o primeiro, das representações visuais - composta por desenhos, pinturas, gravuras, fotos, imagens cinematográficas e televisivas, holográficas e infográficas, ou seja, composto por objetos materiais ou signos que representam nosso ambiente visual; o segundo, chamado de domínio imaterial - composto por visão, fantasias, imaginação enquanto modelo ou representação mental. Ambos não existem de forma separada, pois estão unidos desde a gênese. Não há imagem como representação visual que não tenha surgido de imagens mentais daquele que as produziu, assim como não há imagens mentais que não tenham alguma origem no mundo concreto dos objetos visuais. O que unifica os dois domínios é o conceito de signo ou representação que encontra o seu lado perceptível e o seu lado mental com a combinação de duas ciências: a semiótica e a neurociência cognitiva. Se ambas as abordagens são entendidas como se referindo a diferentes níveis de descrição de processos mentais podemos obter informações em um nível subsimbólico através do conexionismo, e o nível simbólico no cognitivismo, obtendo assim uma complementaridade no entendimento das representações mentais.

A consciência é um conceito sujeito a diferentes interpretações, porque o termo é também usado como uma acepção quantitativa para indicar nível de alerta, isto é, alguém está muito alerta quando está acordado e atento. Pode estar menos alerta e menos consciente quando se encontra sonolento ou ainda inconsciente quando desmaia. O uso da razão implica a busca de informação na memória, e estas são associadas a padrões mentais de comportamento e manifestações fisiológicas que elas teriam provocado quando foram armazenadas, de acordo 
com Lent (2010). A razão é frequentemente substituída pelos neurocientistas por cognição, palavra de origem latina que se relaciona com o ato de conhecer ou cognoscere. A função cerebral que possibilita a cognição é o controle cognitivo, ou a capacidade que as pessoas têm de alinhar seus pensamentos e ações a um nível acima das meras reações ao ambiente, tornando-os abstratos e proativos. Este controle possibilita os comportamentos inteligentes, capazes de antecipar o futuro, coordenar e dirigir os pensamentos e ações. Exemplo de uma atuação controlada é a já citada de Cunningham et al (2004) onde relacionam uma experiência com o processamento de faces de diferentes raças e Phelps et al (2000).

Para Kandell et al (2000) para entender como as pessoas pensam, se comportam, sentem e agem torna-se essencial o entendimento de como as ações integradoras do encéfalo produzem a cognição. Somente com uma combinação de métodos de uma variedade de campos, como biologia celular, neurociência de sistemas, neuroimagem, psicologia cognitiva, neurologia comportamental e ciência computacional é possível chegar a uma abordagem funcional chamada neurociência cognitiva - que com uma abordagem integrada para entender o comportamento, por meio das suas cinco principais áreas: a percepção, a ação, a emoção, a linguagem e a memória - poderá oferecer resultados mais integrais.

As descobertas recentes do funcionamento cerebral estão revolucionando todas as áreas das ciências biológicas, humanas e exatas, contribuindo para maior compreensão do comportamento humano, podendo ser aplicada também no marketing e na comunicação. Os investimentos por parte dos anunciantes em pesquisas experimentais, projetadas para tentar descobrir o que se passa dentro do cérebro dos consumidores são uma tentativa de obter o conhecimento sobre dentre as mensagens que os bombardeiam diariamente, quais são mais relevantes na construção das marcas, quais são mais lembradas e o que é pensado enquanto vêem determinada comunicação (LINDSTROM, 2008).

O comportamento é a exteriorização de um estímulo externo ou interno no qual é acionada a memória para direcioná-lo. Lent (2010) descreve a sequência de etapas a partir da entrada de um evento novo. Primeiramente se aciona a memória ou acessa-se uma informação armazenada para após isso utilizá-la mentalmente na cognição e na emoção para exteriorizar um comportamento. O esquecimento, não em casos patológicos como a amnésia, é entendido como uma propriedade normal da memória e provavelmente é um mecanismo de prevenção de sobrecarga do sistema cerebral dedicado à memorização ou filtragem dos aspectos mais 
relevantes ou importantes de cada evento. Quando de um evento, alguns aspectos serão esquecidos imediatamente, outros serão memorizados durante certo período, e apenas uns poucos permanecerão na memória de forma prolongada, o que é chamado consolidação. A memória é a capacidade que o homem e os animais têm de armazenar informações que possam ser recuperadas e utilizadas posteriormente. Passam pelos processos de aquisição, retenção, evocação e esquecimento. Sua função é ser um guia, um facilitador, para nosso comportamento. Vide Ilustração 13:

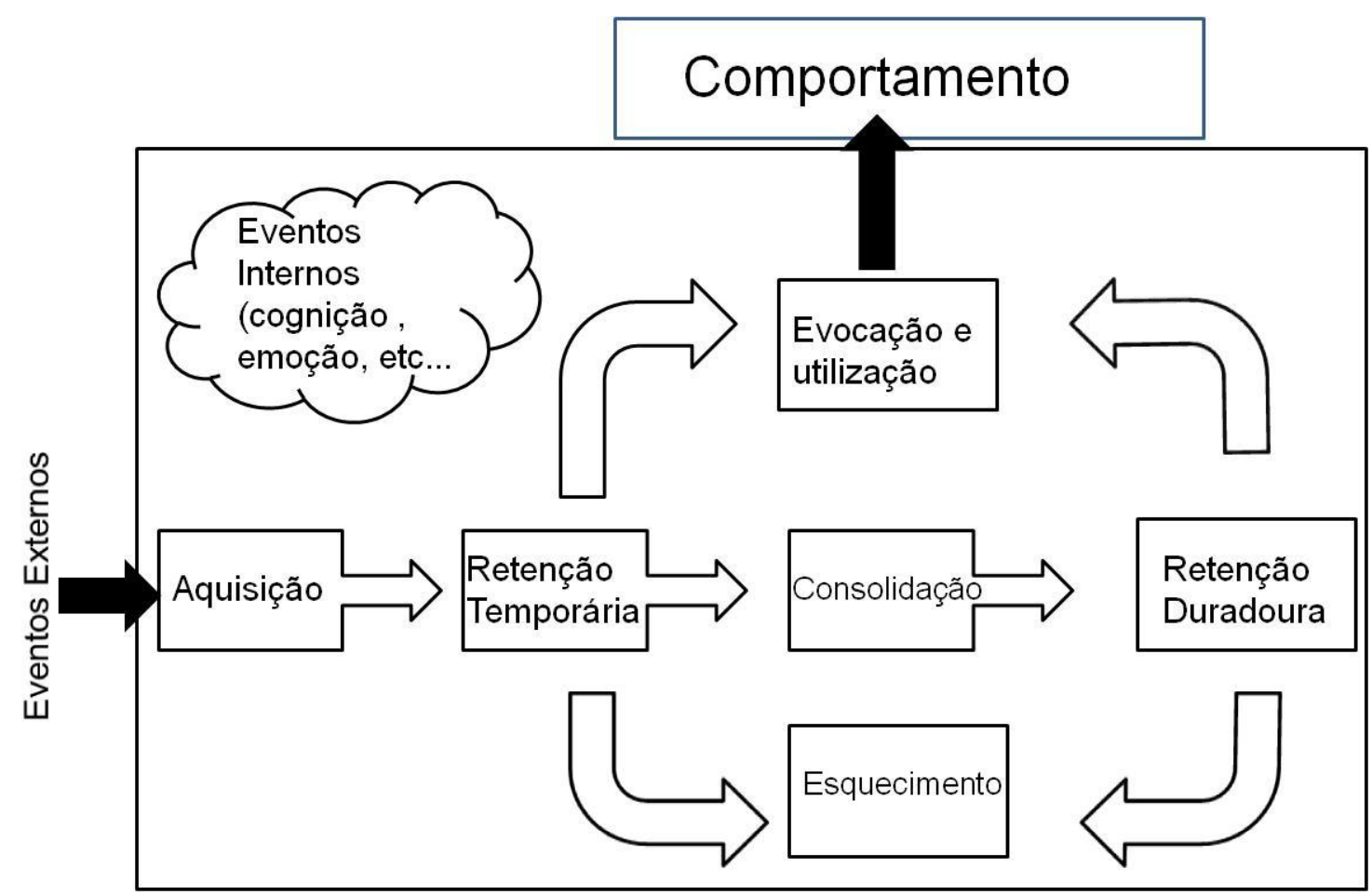

Ilustração 13 - Operação do sistema de memória para o comportamento FONTE: LENT, 2010, p. 649.

De acordo com o autor, para o entendimento do comportamento é crucial o estudo de como a memória é acionada, uma vez que as informações associativas tornam as pessoas capazes de reagir a adventos, preparando suas ações de modo apropriado. A memória - com seu processo de arquivamento seletivo das informações - permite que seja evocada sempre que se desejar, consciente ou inconscientemente, de acordo com a Ilustração 14. 


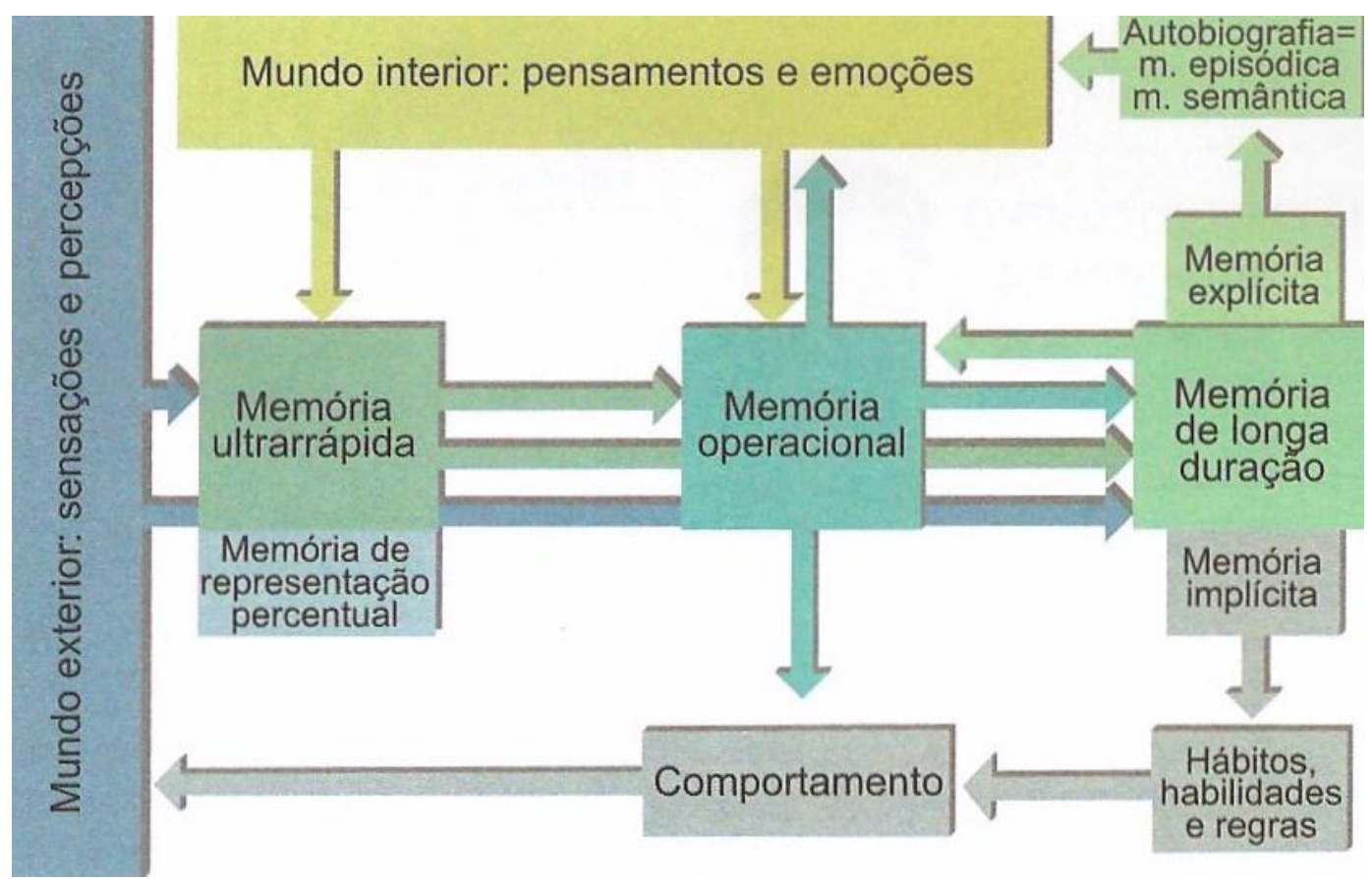

Ilustração14 - As múltiplas relações entre memória, pensamento e comportamento FONTE: LENT, 2010, p. 658.

A utilização da memória permite às pessoas relaxarem, porque o estímulo deve ser inócuo, ou manter-se alerta, porque o estímulo pode ser nocivo. Depreende-se disso que esses são mecanismos muito úteis à sobrevivência dos animais. Esse é o motivo porque tais mecanismos originaram-se precocemente durante a evolução, e mantiveram-se conservados até a espécie humana. São vários os tipos de características da memória, que são divididas enquanto tempo de processamento e natureza de seu conteúdo, como exposto no Quadro 5:

Quadro 5 - Tipos e características da memória

\begin{tabular}{|c|c|c|}
\hline & Tipos e Subtipos & Características \\
\hline Quanto ao tempo & Ultrarápida ou imediata & Dura de frações de segundos a alguns segundors; memória sensorial \\
\hline de & Curta duração & Dura minutos ou horas, garante o sentido de continuidade do presente \\
\hline \multirow[t]{3}{*}{ Retenção } & Longa duração & Dura horas, dias ou anos, garante o registro do passado autobiográfico \\
\hline & & e dos conhecimentos do indivíduo \\
\hline & Explicita ou declarativa & Pode ser descrita por meio de palavras e outros símbolos \\
\hline Quanto & Episódica & Tem uma referência temporal: memória de fatos sequenciados \\
\hline à & Semântica & Envolve conceitos atemporais; memória cultural \\
\hline \multirow[t]{8}{*}{ Natureza } & Implícita ou não declarativa & Não precisa ser descrita por meio de palavras \\
\hline & De representação perceptual & Representa imagens sem significado conhecido; memória pré-consciente \\
\hline & De procedimentos & Hábitos, habilidades e regras \\
\hline & Associativa & Associa dois ou mais estímulos ( condicionamento clássico), \\
\hline & & ou um estímulo a uma certa resposta ( condicionamento operante) \\
\hline & Não associativa & Atenua uma resposta(habituação) ou aumenta-a ( sensibilização), por meio \\
\hline & & de repetição de um mesmo estímulo \\
\hline & Operacional ou memória de tr & Permite o raciocínio e o planejamento do comportamento \\
\hline
\end{tabular}

FONTE: LENT, 2010, p. 650. 
No entanto, a memória, como todas as funções do sistema nervoso, pode ser modulada fortalecida ou enfraquecida por situações que dão contorno aos eventos, como componentes emocionais positivos ou negativos. A emoção é uma experiência subjetiva acompanhada de manifestações fisiológicas e comportamentais detectáveis. A existência dessa expressão exterior, mensurável da experiência emocional permite que ela seja analisada mais facilmente com os métodos da neurociência. Nos seres humanos, a descrição do componente subjetivo de uma emoção é de difícil controle, já que apenas o próprio indivíduo tem acesso a ele, e os demais não podem realizar uma verificação confiável de veracidade ou exatidão. No entanto, é possível analisar uma emoção acompanhando suas manifestações orgânicas e comportamentais e registrar as atividades cerebrais por meio de imagem ou de traçados eletro ou magnetofisiológicos. A emoção representa um importante componente da memória, mas não é o único. O estado de alerta e atenção atuam sobre ela, assim como treinamentos, outras ativações neurais como processos neuroquímicos exercidos artificialmente, até mesmo hormônios, bem como a ansiedade e o estresse que podem ser provenientes de influências biológicas ou sociais.

\subsection{A neurociência para conhecimento do comportamento do consumidor}

A neurociência analisa como o cérebro realiza os processos como memória, sono, e aprendizado. Além disso, também estuda como o pensamento é produzido e sua relação com as emoções e decisões, fornecendo seus componentes, suas mensurações e explicações sobre o comportamento com base nas atividades cerebrais e como elas são afetadas pelo ambiente externo, como descreve Kringelbach e Berridgee (2009) na Ilustração 15. O que se observa são três categorias distintas de reação: a motivação, o prazer e a aprendizagem. Também se demonstra os seus componentes psicológicos, suas medições, e a forma como o processamento psicológico acontece. No estudo se observa que há similaridades entre os circuitos cerebrais ativados nos diferentes processos, o que demonstra a complexidade de avaliar um circuito cerebral quando se detecta uma reação, uma vez que sua ativação pode derivar de diferentes categorias de processos psicológicos. 


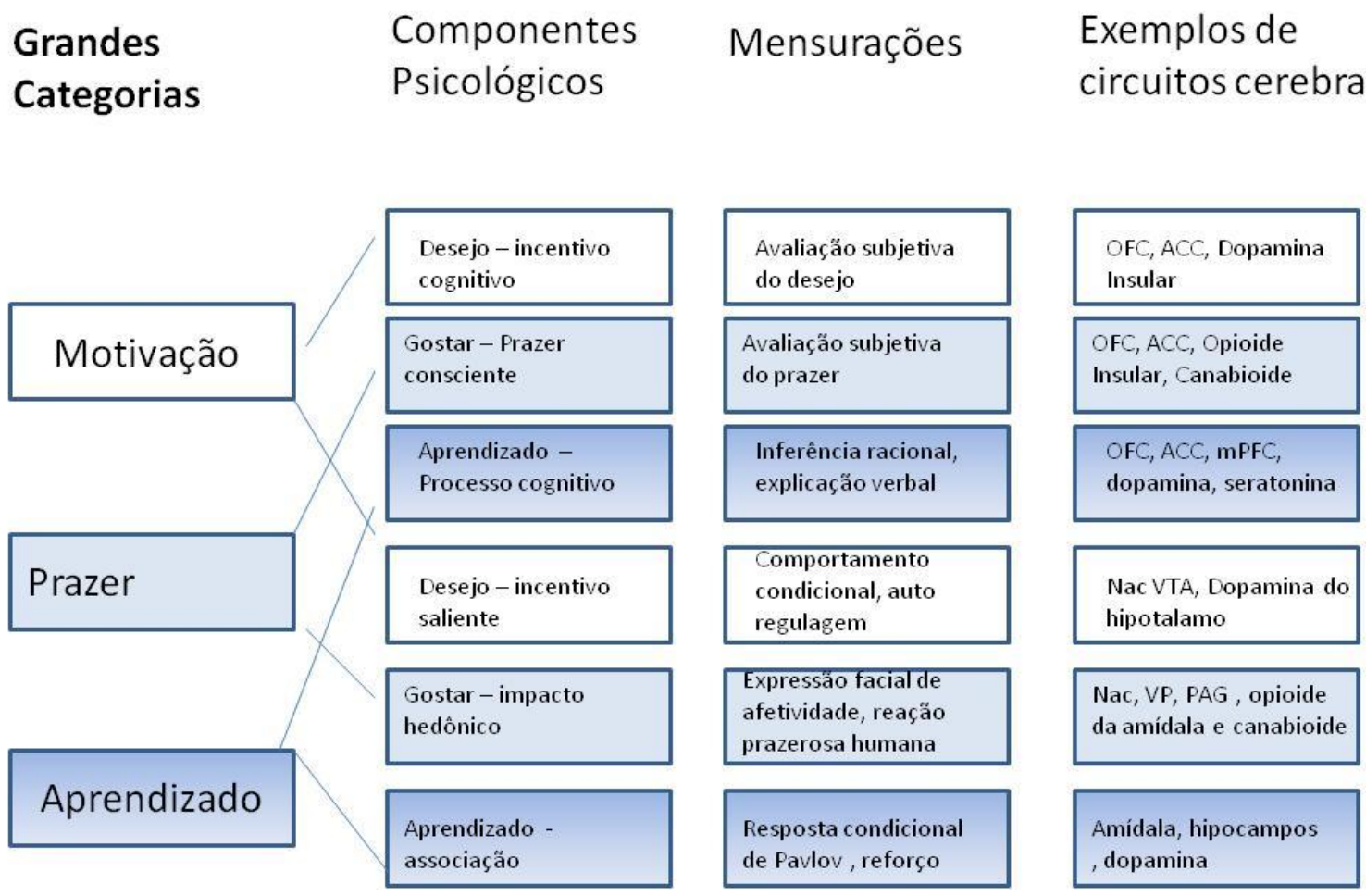

Ilustração 15 - Processos paralelos no cérebro FONTE: KRINGELBACH; BERRIDGEE, 2009, p. 480.

Com foco em aspectos biológicos dos sistemas cognitivos e comportamentais e no papel do sistema nervoso central nos processos geradores de expressão, aprendizado, memória e comportamento, a neurociência tem o desafio de buscar compreender os processos de regiões específicas do cérebro, com o intuito de entender como se dá o comportamento dos indivíduos nas atividades cerebrais. A neurociência avançou nas últimas cinco décadas em função de desenvolvimentos tecnológicos que permitiram a análise por meio de imagens que podem monitorar o funcionamento cerebral em tempo real, e também da evolução das ciências biológicas. Atualmente, os neurocientistas acreditam que para entender como as pessoas raciocinam, comportam-se, sentem-se, agem e se relacionam umas com as outras, é essencial entender como eventos em células individuais levam à cognição. O termo cognição se refere a todos os processos pelos quais a entrada sensorial é modificada, reduzida, organizada, armazenada, recuperada e utilizada (XEREZ, 2005).

De acordo com Cialdini (2007), além de complexo, o processo cerebral em muitos casos pode se dar por processos automáticos, já que os indivíduos têm capacidade mental restrita de armazenamento da memória. O cérebro não pode registrar e processar todas as informações do ambiente e para aumentar sua eficiência desenvolve certas reações aos estímulos recebidos pelo sistema de percepção, intensificando a rapidez de resposta e a tomada de decisão. $\mathrm{O}$ 
indivíduo utiliza reações automáticas desenvolvidas ao longo da vida quando não tem tempo, energia ou recurso cognitivo para fazer uma análise completa da situação. Quando alguém está com pressa, estressado, apresenta incerteza ou indiferença, está distraído ou cansado, a tendência é focar menos nas informações disponíveis e reagir aos pequenos códigos primitivos desenvolvidos durante a vida.

Na interpretação de Xerez (2005), para se entender como o encéfalo permite a cognição, os fundamentos da neurociência não são suficientes, os modelos construídos pela psicologia cognitiva podem fornecer o conhecimento da noção dos estágios de processamento, permitindo assim que a atividade cognitiva possa ser analisada considerando seus componentes interligados. Por isso, para os neurocientistas modernos, essa área responsável pelos estudos sobre o funcionamento cerebral deve ser denominada "neurociência cognitiva", que além da neurociência, tem suas raízes também na neurologia e na ciência cognitiva, sendo assumida como uma área específica em 1970. A área de marketing tem sido uma das mais recentes aplicações da neurociência cognitiva, e alguns autores têm denominado esse novo campo de atuação de neuromarketing.

A neurociência e o marketing: o neuromarketing

A necessidade de um maior conhecimento sobre as atividades de marketing é conhecida. Em 1876, John Wanamaker, executivo que criou a primeira loja de departamentos, já dizia que sabia que metade do investimento feito em marketing era desperdício, porém não sabia qual metade. Para a revista The Lancet Neurology (2004), a invenção do neuromarketing, ou o uso de métodos da ciência cognitiva, como a utilização de máquinas de diagnóstico de imagem no cérebro em marketing, tem como objetivo acessar sinais emitidos na mente para saber se a pessoa responderá de forma favorável ou não a uma marca ou produto e assim antecipar preferências e minimizar erros nas estratégias de mercado das empresas.

O neuromarketing, segundo Fisher et al (2010) foi primeiramente reportado como termo em 2002, em um press release de uma empresa de Atlanta chamada BrightHouse, que anunciou a criação de uma unidade de negócio usando fMRI para estudos de marketing. O fato atraiu críticas e conflitos que envolviam a universidade de Emory, pois utilizava seus espaços, seus estudos de imagem e pelo menos um professor de psiquiatria para tais estudos. Mas antes desse evento, estudos que envolviam reações do consumidor à televisão utilizando 
eletroencefalograma já eram utilizados por corporações e, uma patente sobre a utilização da neuroimagem como ferramenta de marketing foi efetuada em agosto de 2000, por Gerald Zaltman e Stephen Kosslyn na Universidade de Harvard (adendo), chamada "Neuroimaging as a marketing tool".

Em Outubro de 2004, o jornal The New York Times publicou uma matéria polêmica. A jornalista Sandra Blakeslee descreve as novidades do neuromarketing no artigo: "If you have a buy Button in your brain, what pushes it?" e levanta suas dúvidas diante das técnicas de imagem utilizadas em pesquisa de mercado.

Recentemente, pesquisadores propuseram diferentes definiçõos de neuromarketing. Mais especificamente:

- Lee et al (2007) definiram neuromarketing como uma área acadêmica e não uma aplicação das técnicas de neuroimagem para vender produtos.

- Hubber e Kenning (2008) vêem neuromarketing como uma atividade de negócios ao invés de uma área acadêmica, denominada neurociência do consumidor. Para eles o neuromarketing seria somente uma aplicação dos conhecimentos adquiridos nesta ciência dentro de um escopo de práticas gerenciais.

Para Fisher et al (2010), neuromarketing poderia ser comparado à neuroeconomia como uma disciplina acadêmica, já que estuda vários aspectos da economia no processo de decisão e passou por um extenso desenvolvimento como campo e ainda produz evidências do processo de decisão no contexto atual e real do mundo. Os pesquisadores utilizam produtos de consumo para estudar conceitos como processamento sensorial, escolha e avaliação de perdas e ganhos, como fizeram MacClure et al (2004), que estudaram as diferenças entre as marcas Coca-Cola e Pepsi usando fMRI para obter entendimento de símbolo cultural e não para oferecer desenvolvimento de design para o mercado onde atuam.

Na literatura atual, os estudos relatados de neuromarketing combinam métodos científicos de imagem não invasivos que medem o nível da atração ou repulsão emocional que os consumidores experimentam quando estimulados pela campanha de uma marca. Um destes métodos é o SST (steady state topography), versão avançada de um eletroencefalograma que traz a vantagem de poder medir as reações instantâneas do cérebro, o outro é o que utiliza o fMRI, um escâner que pode marcar áreas muito pequenas que foram estimuladas e é o aparelho mais sofisticado disponível no mercado. 
Há uma variedade de tecnologias que permitem diferentes medições do funcionamento cerebral. São elas, de acordo com Ariely e Berns (2010):

- Functional Mri (fMRI): A técnica utiliza um escâner de ressonância magnética para medir o nível de oxigenação do sangue-dependente (BOLD). As mudanças BOLD são geralmente correlacionadas à atividade sináptica e este aparelho mede regiões muito pequenas, porém não de forma muito rápida (resolução de 1-10 mm e de 1-10 segundos). Geralmente, quanto maior e mais profunda a área estudada, mais lenta é a sua resolução. Dentre as tecnologias de imagem descritas esta tem uma vantagem substancial na resolução de pequenas estruturas e naquelas que estão no fundo do cérebro. No entanto, algumas regiões importantes do cérebro, especialmente o córtex órbito frontal, são afetadas por outros sinais e isso pode reduzir a capacidade de obter informações úteis. O aparelho mais sofisticado nos Estados Unidos custa cerca de US\$ 1 milhão e têm custos operacionais anuais de US\$100.000 a US\$300.000.

- Electroencephalography (EEG): Os eletrodos de EEG são aplicados ao couro cabeludo com uso ou não de gel e as alterações de medidas no campo elétrico na região do cérebro logo embaixo são capturadas. A EEG tem uma alta resolução temporal (milissegundos) e pode, portanto, detectar breves eventos neuronais. Porque o crânio dispersa o campo elétrico, o EEG tem baixa resolução espacial $(\sim 1 \mathrm{~cm})$ e sua qualidade depende de quantos eletrodos são usados. Este número pode variar de dois até centenas de alta densidade matrizes. Quanto maior o número de eletrodos, melhor a resolução espacial. Além da baixa resolução espacial, o EEG tem pouca sensibilidade para as estruturas cerebrais profundas. $\mathrm{O}$ custo dos equipamentos pode ser baixo (<US\$10.000), mas aumenta com alta densidade de matrizes e os recursos necessários para concomitantemente processar os dados. Uma técnica comum de sua utilização é para medir a assimetria esquerdo-direita frontal. Esta investigação tem sugerido que a atividade relativamente maior na região frontal esquerda está associada a estados emocionais positivos, ou a unidade de motivação para uma aproximação de um objeto. Apesar da forte correlação entre EEG da assimetria frontal e traços de personalidade, o grau em que a assimetria de mudanças é medida, momento a momento ainda é debatido. Alguns sugeriram um mínimo de 60 segundos para estimar o poder da assimetria, caso em que a vantagem temporal do EEG sobre o fMRI é perdido. Embora essa abordagem tenha sido utilizada para medir flutuações momentâneas na emoção em resposta à propaganda, sem contabilização de 
autocorrelações no tempo ou múltiplas comparações estatísticas, a validade de tais abordagens é duvidosa.

- Magneto encephalography (MeG): Um parente mais caro que o EEG, o MEG mede as mudanças nos campos magnéticos induzidos pela atividade neuronal; tem a mesma vantagem da alta resolução temporal e, porque o campo magnético é menos distorcido pelo crânio do que o campo elétrico, apresenta melhor resolução espacial do que o EEG. Como EEG, o MEG é mais sensível a sinais superficiais corticais (principalmente nos sulcos cerebrais). Para funcionar, requer um quarto blindado magneticamente e detectores supercondutores de interferência quântica para medir os sinais magnéticos no cérebro. A instalação do MEG custa aproximadamente US\$ 2 milhões.

- Transcranial magnetic stimulation (TMS): Um núcleo de ferro, muitas vezes na forma de um toróide envolto em fios elétricos, cria um campo magnético forte o suficiente para induzir correntes elétricas nos neurônios subjacentes quando colocados na cabeça. O TMS pode ser usado como um único pulso, pulso pareado ou estimulação repetitiva, e os efeitos neuronais variam de facilitação para a inibição da transmissão sináptica. Como ferramenta de pesquisa, o TMS tem sido usado para estudar o papel causal de regiões específicas do cérebro em tarefas específicas por torná-los temporariamente 'off-line', ou seja, desligá-los para separar a análise.

Para os autores, a incorporação de técnicas de neuroimagem para as ciências que estudam a tomada de decisão, por exemplo, a neuroeconomia, fez com que houvesse o interesse no estudo de marketing e sua busca pelo entendimento do consumidor. Como resultado, há alta expectativa de que as técnicas de neuroimagem provenientes da neurociência possam resolver alguns problemas cruciais de marketing. Uma esperança proeminente é de que as técnicas da neuroimagem possam acelerar tanto os processos de marketing como economizar dinheiro. Outra esperança é de que a neuroimagem possa revelar informações sobre as preferências do consumidor inalcançáveis através dos métodos convencionais. Acredita-se que as pessoas não possam articular suas preferências completamente quando questionadas para expressá-las de forma explícita, pois as mentes dos consumidores contêm informações ocultas sobre suas reais preferências, que influenciariam seu comportamento de compra. Portanto, é esperado que os custos incorridos com as aplicações de técnicas de neuroimagem possam ser compensados pelo benefício de melhorar o design de produto ou qualquer outro atributo capaz de aumentar as vendas e oferecer retorno aos investimentos realizados. Em teoria, os 
autores acreditam que a imagem iluminada das áreas cerebrais possa não só apontar o que as pessoas gostam, mas também o que comprarão.

Neuromarketing e seus estudos acadêmicos

Há um vasto potencial de contribuições e prioridades das aplicações da neuroimagem dentro da literatura de marketing, sendo as áreas de maior interesse mais focadas em marcas e comportamento e de utilização em particular de técnicas mais frequentes de avaliação. As propostas são feitas utilizando uma aplicação pós-design, em particular como medir a eficiência de campanhas de comunicação, preço, embalagem, enfim, estímulos prontos. Uma forma de utilização do teste é mostrar aos participantes uma campanha publicitária em formato de material impresso ou televisivo, e medir como a mente responde em seu processo de oxigenação ou BOLD (blood oxygenation level-dependent) que acontece como uma medição da ativação neural. Kaplan et al (2007) demonstram a dificuldade em estudo realizado com fMRI para detectar as diferentes áreas de ativação durante um estudo sobre candidatos a presidência americana durante a eleição de 2004. Em leitura do nível de oxigenação obtida pelo estímulo da figura de um candidato o que se vê é que a atividade cerebral ao entrar em contato com o estímulo é modificado em termos de localização de sua ativação, isto é, ela depende da preferência partidária do entrevistado. Além desta descoberta, as reações emocionais em relação ao candidato da oposição são moduladas por controles cognitivos, a reação envolve muito mais que apenas um reconhecimento inicial, mas um sistema completo que é ativado quando busca memórias, associações emocionais e o nível de significado social do estímulo.

Outro estudo, realizado por Astolfi et al (2008), agora utilizando EEG - medindo ativação elétrica das regiões estimuladas do cérebro a comerciais televisivos, provou que os mais lembrados após alguns dias do teste ativam regiões distintas do cérebro em comparação com os que são esquecidos, sugerindo a necessidade de maior investigação de áreas ligadas à memorização na busca por entendimento do comportamento.

Uma segunda razão pela qual os profissionais estão interessados na imagem cerebral é que esperam que da técnica provenha um método preciso que possa ser adotado antes que o produto exista, prevendo preferências subjacentes permanecendo insensíveis aos tipos de 
abordagens subjetivas que muitas vezes são a marca registrada das avaliações atuais, quando comparados com dados resultantes de pesquisas de marketing tradicionais.

Em Young (2002) e Rossiter et al (2001) houve o estudo das reações à propaganda em programas de TV e sua capacidade de lembrança de marca, atenção e a possível eficiência de imagens em retenção de marcas na memória. Braeutigam et al (2004) também contribuíram com o estudo sobre previsibilidade e imprevisibilidade de escolha com base na frequência de uso e gap entre o estímulo de marketing. Senior (2003) contribuiu com seu estudo sobre estímulo em regiões diferentes do cérebro associado com prazer e remuneração diferentes por sexo de respondente. O estudo de Erk et al (2002) demonstra a análise realizada por cientistas da Universidade de Ulm (Alemanha), juntamente com a empresa Daimler Chrysler em um artigo acerca da percepção visual sobre automóveis. Plassmann et al (2008) relatam diferenças em regiões de ativação cerebral em uma experimentação de vinhos quando há variação de expectativa de preços, oxigenando regiões ligadas ao prazer quando o preço é percebido como mais alto.

Kawashima (2001) apresentou o estado do consumidor enquanto participava de um game eletrônico. Segundo o estudo, o córtex pré-frontal é subjugado e enfraquece os neurônios, impedindo o desenvolvimento do cérebro. Por sua vez, isso afetaria a capacidade de uma criança de controlar comportamentos antissociais. Seus experimentos foram realizados comparando as varreduras do cérebro, scans, envolvendo adolescentes jogando Nintendo, um jogo de console. Depois de cinco anos de estudo patrocinado, inclusive pela indústria de games, Kawashima não está seguro dos resultados, denomina seu resultado de suposições e afirma que mais estudos são necessários, utilizando outras ciências para tirar conclusões. No entanto desenvolveu um novo programa chamado Brain Training game onde, diferente do jogo anterior, demanda interação do usuário na realização do jogo promovendo atividade na região do córtex pré-frontal que envolve desafios, cálculos, quebra-cabeças, leitura em voz alta e escrita na tela do controle do jogo.

Em teste de ativação neural realizada entre Coca-Cola e Pepsi por McClure et al (2004) se descobriu que há uma ativação consistente em uma área pré-frontal na degustação anônima entre os dois produtos mas, com mudança significativa de preferência de intensidade de resposta quando houve a colocação da marca no produto. 
O que se conclui das investigações acadêmicas é que se utiliza fMRI ou EEG na maior parte dos estudos e o que se busca é a identificação das correlações entre estímulo e área de ativação no intuito de aumentar o conhecimento sobre o comportamento. No entanto, o que se verifica é a falta de recomendação em termos de número de participantes ideais, bem como obtenção de resultados válidos para replicação. Conforme menciona Spiers e Maguire (2006), apesar de estudos envolvendo a análise de comerciais estarem começando a oferecer progresso, o fato da utilização do fMRI depender da passividade do analisado pode implicar em dados não comprováveis na vida real, uma vez que muitas reações diárias sofrem a influência e o envolvimento do ambiente em que as pessoas vivem. Porém, é unanimidade a recomendação de que maiores estudos continuem a ser feitos.

Neuromarketing e suas barreiras

Para Lee et al (2007) a maioria das ciências sociais ainda não adotou a neuroimagem como uma ferramenta standard nem como procedimento para pesquisa. A neuroeconomia começou com a utilização da neuroimagem em suas pesquisas; o marketing ainda está lento no despertar para os benefícios das pesquisas de imagem, independentemente de ambos os campos de estudo dividirem preocupações comuns relacionadas a processos de decisão e troca. As barreiras para o desenvolvimento em marketing poderiam ser a intimidação, resultante da neurociência e psicologia cognitiva e a obtenção de técnicas de imagem pelos departamentos de marketing, porém, a maioria dos acadêmicos está em grandes campus universitários, onde as facilidades estão disponíveis. Aparentemente o maior bloqueio se dá pela falta de conhecimento das devidas técnicas, o que leva a não consideração das mesmas para a exploração como potencial contribuinte nos estudos. A possível solução seria uma contribuição entre departamentos - escolas e clientes, isto é, entre a área de negócios e a neurociência para desenho de projetos e procedimentos de forma conjunta.

As barreiras a serem transpostas estão relacionadas à moral e ética da utilização dos resultados do estudo para aumentar o consumo de produtos. Isto se baseia no fato de que o escopo de marketing, em suas pesquisas nas escolas de negócio, é essencialmente sobre entendimento, explicação e predição do comportamento relevante seja individual, grupal ou organizacional para os mercados. Assim, a maior barreira de desenvolvimento do neuromarketing na literatura da neurociência deve-se ao fato do interesse comercial de aplicação dos conhecimentos gerados na pesquisa acadêmica para vender mais produtos para 
a população, formando assim uma barreira natural por propor a utilização das imagens cerebrais para influenciar e infringir a privacidade pessoal. Para os autores, recentemente neuromarketing passou a significar a aplicação das técnicas de neuroimagem para vender produtos. No entanto, esse entendimento do comportamento de consumo pode ter seu escopo mais amplo. Pode ser definido como um campo de estudo de aplicação dos métodos neurocientíficos para analisar, entender o comportamento do consumidor em relação aos mercados e ao mercado de trocas, distanciando assim o neuromarketing com finalidade do uso das neuroimagens sob o aspecto do interesse comercial, incluindo a maioria das áreas de interesse como, por exemplo, a pesquisa inter e intraorganizacional, tão comum na literatura de pesquisa de marketing. No entanto, mesmo no círculo acadêmico existem preocupações sobre a habilidade dos métodos neurológicos em levar em consideração a panóplia das variáveis relevantes nas teorias de marketing, como mencionado por Spiers e Maguire (2006). Estes consideram o progresso da utilização do fMRI, como já mencionado, no entanto preocupam-se com a sua aplicação laboratorial e a capacidade de comprovação na vida real.

\section{Neuromarketing em Pesquisa de Mercado}

Várias empresas oferecem soluções de neuroimagem para problemas comerciais, entre elas a BrightHouse e NeuroFocus, empresas americanas, e a Neurosense, com base na Inglaterra. Pouca informação é publicável, uma vez que trabalharam em conjunto com empresas e seus desafios comerciais confidenciais. Várias empresas como a EmSense, a Sands Research, a MindLab International e a NeuroSense, agora se especializam nas últimas técnicas de imagem como EEGs e M.R.I. e nas técnicas de biometria como eye-tracking, medição de reação na pele como temperatura, contração muscular ou respostas faciais a produtos e seus estímulos. Empresas como Google, CBS, Disney, Frito-Lay e A \& E Television, bem como algumas campanhas políticas já utilizaram neuromarketing para testar as reações do consumidor. Em 2008, a empresa multinacional de pesquisa, Nielsen, investiu em outra empresa, a NeuroFocus, uma das maiores da área, adicionando assim credibilidade para o campo de investigação.

A neurociência, apesar de sua recente utilização em pesquisa de mercado, está cada vez mais oferecendo novidades. Empresa como a Millward Brown lançou uma nova divisão dedicada ao tema e a revista americana New Scientist utilizou técnicas de imageamento para projetar um estudo para sua capa. 
Lindstrom (2008) relata que as técnicas de neuroimagem já são utilizadas para outros diagnósticos médicos como tumores, doenças cardíacas, ou diagnósticos psicológicos como psicoses, sociopatias, doenças bipolares. Ele acredita que de forma alguma os consumidores podem expressar algo que realmente pensam para estranhos, e mais do que isso, reações e emoções são encontradas no cérebro em curto espaço de tempo e não de forma consciente traduzida em palavras descritas em um questionário, o que justifica seu descrédito nas investigações tradicionais utilizadas para investigar construção de marca. Além de outros estudos, o autor se propõe a apresentar em seu livro o maior estudo de neuromarketing com 2081 voluntários de cinco países (USA, Inglaterra, Alemanha, Japão e República da China) pesquisados entre os anos de 2004 a 2007 com os custos de aproximadamente US\$ 7 milhões, subsidiados por oito multinacionais. O livro explora diversos temas em atividades de marketing e relata conhecimentos que vão além dos oferecidos por pesquisas tradicionais de mercado investigando o consciente e o inconsciente dos consumidores. Os assuntos investigados são: campanhas antitabagistas empregadas pelo governo; merchandising e sua lembrança; comportamento e escolhas de marcas espelhando em outras pessoas; campanhas subliminares e seu reconhecimento; rituais, superstições e religião e seus impactos em hábitos de compra; efeitos somáticos da comunicação; utilização dos cinco sentidos em campanhas; pesquisa e predição de comportamento; o apelo do sexo na comunicação. O autor, em seu capítulo dedicado a campanhas antitabagistas descreve um estudo empregado em 123 países do mundo pelos seus governos em prol da conscientização dos problemas causados pelo vício, e nele retrata o resultado tanto de forma consciente, através da aplicação de questionários quanto de forma inconsciente, por meio da utilização de escâner nos mesmos respondentes. A campanha traz fotos dos malefícios causados pelo fumo nas embalagens de cigarro com o objetivo de influenciar os fumantes ao abandono do vício. Medições do estímulo visual foram realizadas de forma verbal e também cerebral, bem como do tempo das reações através do escâner. O interesse pelo estudo baseia-se no fato de que apesar do esforço das campanhas de conscientização sobre as consequências do fumo, um terço de homens no mundo continua fumando e, aproximadamente 15 bilhões de cigarros ainda são vendidos por dia. Número este na China, um total de fumantes maior que o número de cigarros vendidos nos Estados Unidos, Rússia, Japão e Indonésia juntos.

O que se obteve do estudo apresentado por Lindstrom (2008) é que em resposta consciente à campanha há um efeito inibitório ao vício, e este consegue retratar o mal causado pelo fumo. No entanto, o que se obteve perante os resultados apresentados pelo fMRI é que, não só o 
efeito de inibição não é verdadeiro, como ao contrário do que se esperava, perante a visualização das imagens das doenças causadas pelo fumo, os cérebros foram estimulados em uma área chamada nucleus accumbens. De acordo com a Ilustração 16 esta é a área onde os neurônios são estimulados quando o corpo deseja algo, seja álcool, drogas, tabaco, sexo ou jogo, e que requer altas doses do que causou o estímulo para voltar ao seu estado original.

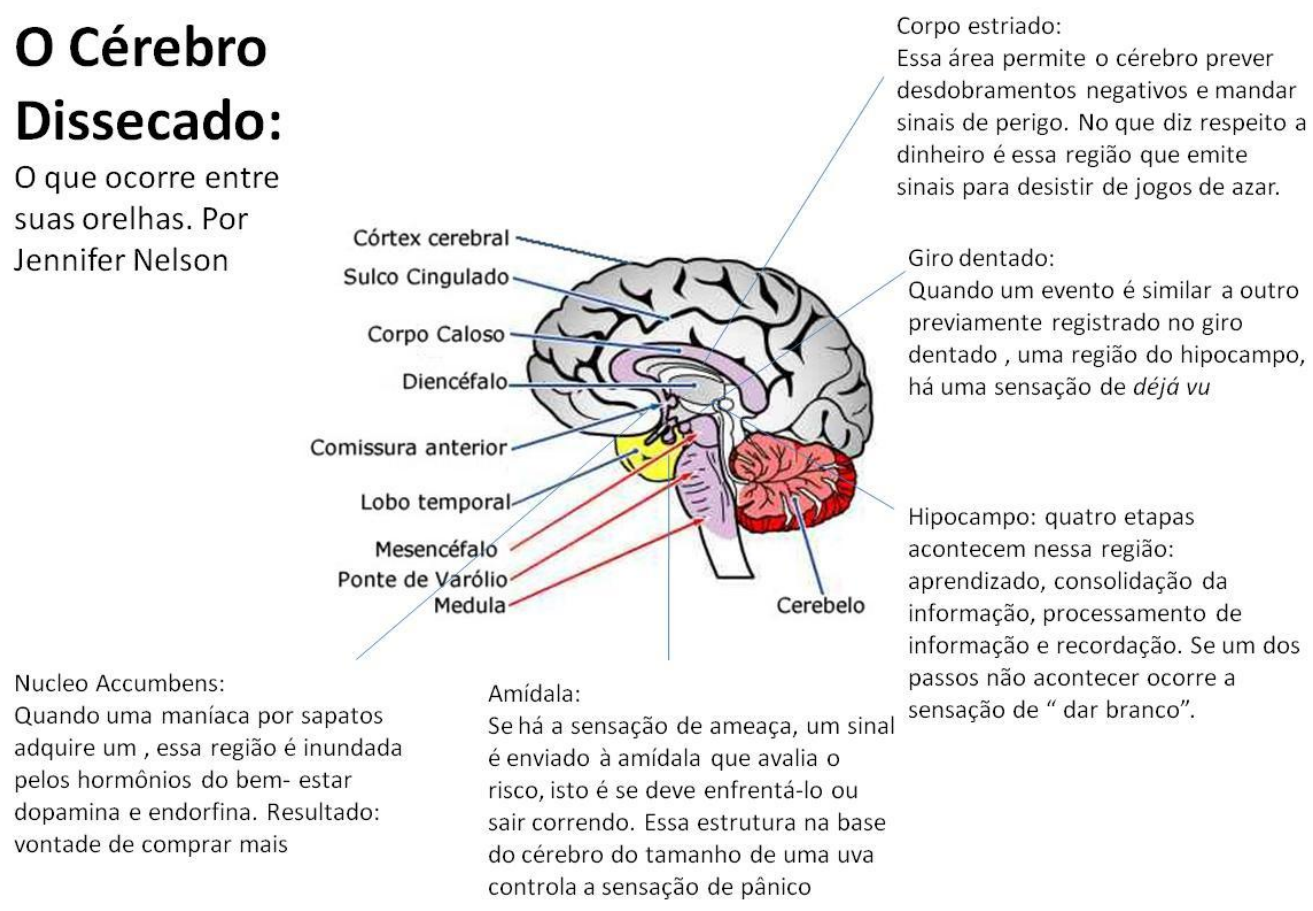

Ilustração 16 - O que ocorre no cérebro FONTE: NELSON, 2009, p. 7.

Para Lent (2010) o aumento da atividade registrada por meio de neuroimagem funcional no núcleo acumbente, ou nucleus accumbens, se dá por vivência de prazer, ou estimulação elétrica no mesmo local. Portanto, há um sistema ou circuito encarregado de produzir tanto a vivência emocional de prazer como reações comportamentais correspondentes em determinados estímulos fisiológicos ou artificiais.

Como evidencia Lindstrom (2008), apesar da resposta consciente dos respondentes perante os questionários, inconscientemente o cérebro é estimulado de forma distinta, isto é, as campanhas aplicadas no mundo todo estariam estimulando os fumantes a buscarem o consumo do cigarro, pois as imagens estimulariam memórias de vivências de prazer. $\mathrm{O}$ estudo, no entanto, não oferece dados para análises mais profundas ou averiguações de sua aplicação, método, protocolo e análise. O que ele fornece é uma reflexão interessante e um 
convite para que outros estudos da ciência da cognição e semiótica possam dar continuidade e explorar, com informações novas e diferentes, a percepção, simbólica ou subsimbólica, outras manifestações cerebrais ou mesmo confirmar os resultados do estudo em novo experimento.

O que se vê em variados estudos realizados por empresas de pesquisa de mercado, como exemplo a Neurofocus, é que se utiliza, além de instrumentos de imagem da neurociência, uma série de complementações de pesquisas tradicionais qualitativas e também medições das reações corporais ou biométricas, sejam elas elétricas, químicas ou mecânicas. A Biometria, de acordo com Jain et al (2002) é a ciência que identifica os indivíduos baseado em suas características fisiológicas ou comportamentais, com as propriedades fundamentais de universalidade, unicidade, permanência, mensuração e evasão.

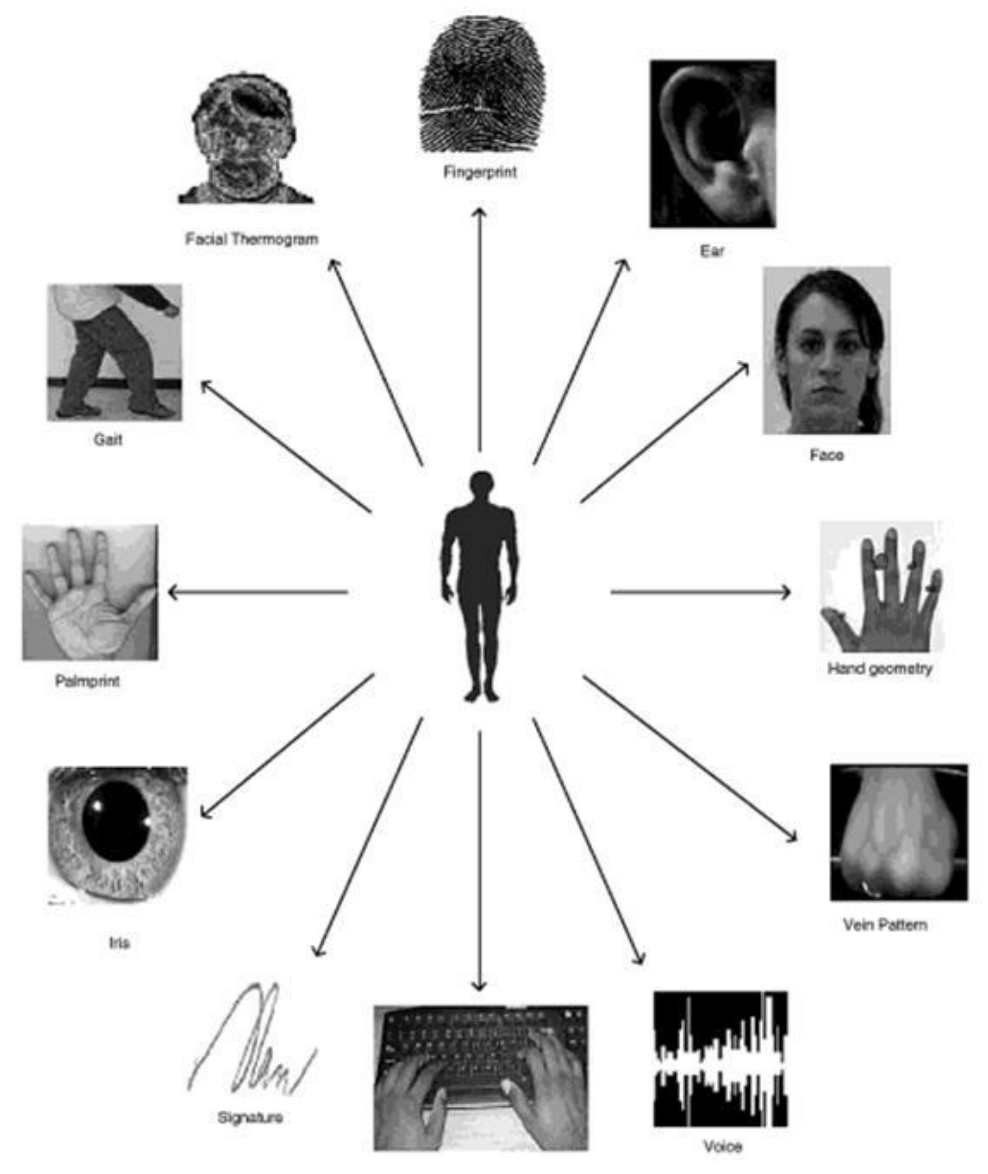

Ilustração 17 - Exemplo de medições biométricas FONTE: JAIN et al, 2010, p. 4.

Há um número de aplicações comerciais e civis em ascensão e ao mesmo tempo, um número de preocupação legítima sendo levantada pela utilização da biometria para várias aplicações, sendo mais significativas as relacionadas aos custos, privacidade e desempenho. Para uma 
maior utilização das medidas biométricas se materializar é necessário que haja um maior número de estudos sistemáticos e fundamentais. Cada tecnologia biométrica apresenta fortalezas e limitações. Em nenhuma aplicação única espera-se atingir todas as necessidades de avaliação. Uma breve comparação das catorze diferentes técnicas biométricas amplamente utilizadas ou ainda em investigação de uso é detalhada na Ilustração 17. A utilização de determinada técnica deve ser um cruzamento entre as características da aplicação e as propriedades da mesma. Algumas aplicações necessitam treinamento, outras necessitam ciências de sua aplicação pelo respondente, outras possuem limitações legais em determinados países. Portanto uma aplicação típica envolve a avaliação completa do que se deseja avaliar, a amplitude de aplicação, a possibilidade de sua aplicação, coleta, credibilidade dos dados coletados, manutenção dos mesmos e aceitação nos mercados, bem como de seus entrevistados. O Quadro 6 descreve uma gama de possibilidades de avaliação das reações individuais. As empresas de pesquisa de mercado mensuram a aplicação da biometria em áreas diversas como medições de Iris e de retina, direcionamento e fixação do olhar, medição de reação facial e termogramas.

\begin{tabular}{|c|c|c|c|c|c|c|c|}
\hline Biometria & $\begin{array}{l}\text { Univers } \\
\text { alidade }\end{array}$ & $\begin{array}{l}\text { Singulari } \\
\text { dade }\end{array}$ & $\begin{array}{l}\text { Perma } \\
\text { nencia }\end{array}$ & Coleta & $\begin{array}{l}\text { Performan } \\
\text { ce }\end{array}$ & Aceitação & Engano \\
\hline Face & Alto & Baixo & Medio & Alto & Baixo & Alto & Baixo \\
\hline $\begin{array}{l}\text { Impressão } \\
\text { digital }\end{array}$ & Medio & Alto & Alto & Medio & Alto & Medio & Alto \\
\hline $\begin{array}{l}\text { Geometria da } \\
\text { mão }\end{array}$ & Medio & Medio & Medio & Alto & Medio & Medio & Medio \\
\hline Datilografia & Baixo & Baixo & Baixo & Medio & Baixo & Medio & Medio \\
\hline Veia da mão & Medio & Medio & Medio & Medio & Medio & Medio & Alto \\
\hline Iris & Alto & Alto & Alto & Medio & Alto & Baixo & Alto \\
\hline Scan de Retina & Alto & Alto & Medio & Baixo & Alto & Baixo & Alto \\
\hline Assinatura & Baixo & Baixo & Baixo & Alto & Baixo & Alto & Baixo \\
\hline Voz & Medio & Baixo & Baixo & Medio & Baixo & Alto & Baixo \\
\hline Termogramas & Alto & Alto & Baixo & Alto & Medio & Alto & Alto \\
\hline Odor & Alto & Alto & Alto & Baixo & Baixo & Medio & Baixo \\
\hline DNA & Alto & Alto & Alto & Baixo & Alto & Baixo & Baixo \\
\hline Andar & Medio & Baixo & Baixo & Alto & Baixo & Alto & Medio \\
\hline Ouvir & Medio & Medio & Alto & Medio & Medio & Alto & Medio \\
\hline
\end{tabular}

FONTE: JAIN et al, 2002, p.16 
A biometria mostra que há muitas formas de reações e uma complexidade das técnicas de medição, muitas vezes utilizadas em conjunto para aumentar a precisão do diagnóstico da reação. Nos estudos relacionados à marca, produto, embalagem, comunicação, entretenimento e ponto de venda, realizados pela empresa NeuroFocus, o que se encontrou para captura das métricas de reações humanas foram: EEG de alta definição, eye-tracking (um aparelho que utiliza câmera e óculos 3D para captura de foco e localização do olhar e seu tempo de duração) e o chamado GSR (galvanic skin response), uma medição de condutância da pele em reação ao estímulo apresentado. Nenhuma das medições é realizada de forma isolada, mas sim combinada, dependendo do estudo em questão. O que se observa na Ilustração 18 são alguns exemplos de técnicas de captação de reações individuais.

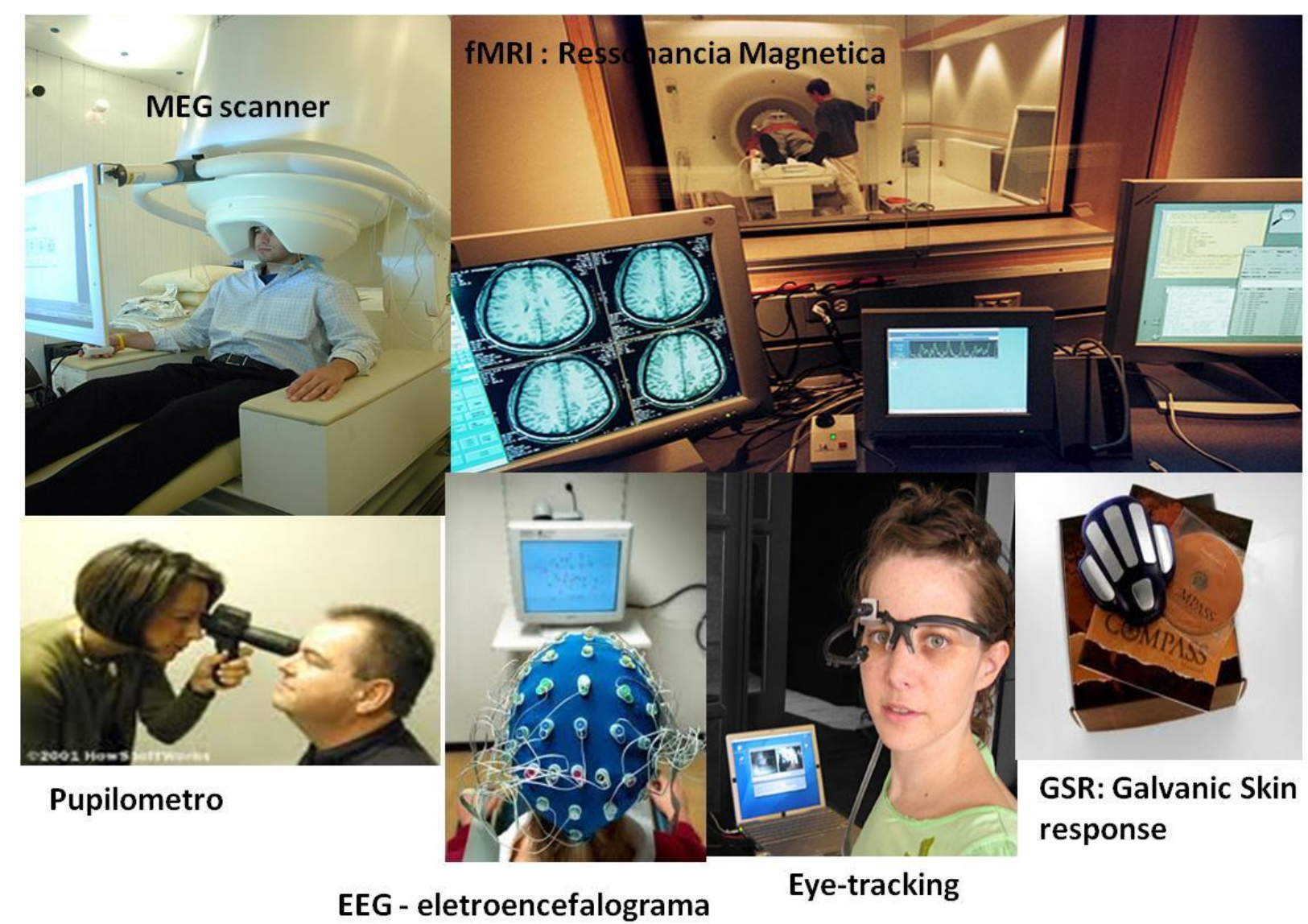

Ilustração 18 - Diversas formas de medições

Jacob e Karn (2003, p. 589) descrevem que os movimentos do olhar, como qualquer outra reação passiva e ação não comandada como gesto e conversação, são frequentemente não intencionais e inconscientes, portanto tem que ser interpretados cuidadosamente para evitar interferências nas reações do indivíduo perante o estudo. Nos movimentos do olhar pode ser encontrado um problema chamado "toque de Midas", quando da utilização de um eye tracker. 
Como o indivíduo não está acostumado a operar um aparelho simplesmente com o movimento dos olhos sem que isso ocorra sem uma ação, o que acontece é que após focar o olhar em algum lugar, outro comando ocorre em sequência e interfere na leitura do que gerou o estímulo inicial. O estudo dos movimentos dos olhos é um exemplo de como a avaliação de reações automáticas a estímulos passivos requerem cuidado no desenho da interface para evitar problemas em interpretar participação ou não na atividade. Em adição a este tipo de medição, uma variedade de características psicológicas do participante pode ser monitorada e sua informação pode ser utilizada para modificar o diálogo com o aparelho de medição e seu usuário. O medidor de dilatação pupilar (pupil diameter) e o GSR são exemplos de medições relativamente fáceis e confortáveis de serem utilizadas. Porém, outros possíveis enganos de interpretações podem ocorrer. Uma medição mais difícil de ser obtida é o eletroencefalograma, mas alguns progressos foram realizados evocando sinais potenciais em tempo real (WICKENS, 1983). Lewis (1980) reporta resultado mais preciso com um pesado detector supercondutor ao invés dos eletrodos convencionais que, com melhorias de tecnologias, pode oferecer melhor visualização de atuação, particularmente se a condutividade em altas temperaturas tornar-se prática. Talvez a fronteira final de um aparelho medidor de inputs e outputs seja aquele capaz de medir e estimular os neurônios diretamente ao invés de ler por meio de tradutores corporais. Infelizmente a proposta é uma situação irreal para o momento presente, mas poderá algum dia ser a forma principal de medição das reações do indivíduo.

Berka et al (2005) afirmam que apesar de inúmeros parâmetros fisiológicos terem demonstrado por meio de índices cardiovasculares diâmetro pupilar, movimentos do olhar e sua medição e reações da pele com o GSR em mudanças no estado cognitivo, o EEG é o único sinal fisiológico que consegue refletir mudanças sutis em alerta, atenção e carga de trabalho que podem ser identificadas e quantificadas em segundos. Os índices de mudanças cognitivas medidas por meio do EEG são sensíveis e confiáveis em sua correlação com desempenho. Uma demonstração de sua aplicação em um laboratório é oferecida na Ilustração 19, onde a reação de um indivíduo é mensurada enquanto o mesmo realiza uma experiência em sua navegação no computador. 


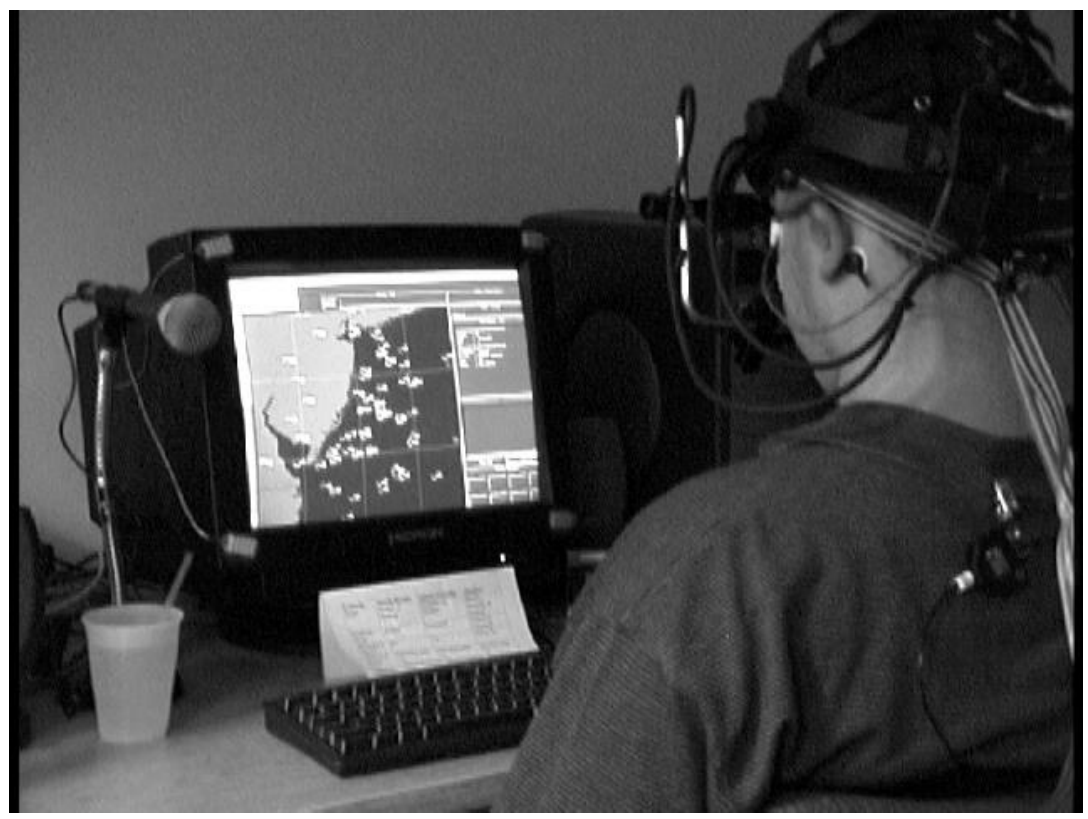

Ilustração 19 - Participante em simulação FONTE: BERKA et al, 2005. pag. 3.

Barreto e Zhai (2003, p. 496) afirmam que se pode obter uma avaliação on-line dos estados afetivos por meio de uma reação e dados de sinais fisiológicos. Esta, pela utilização de volume da pressão sanguínea, GSR, temperatura da pele e dilatamento pupilar (Blood Volume Pulse, Galvanic Skin Response, Skin Temperature and Pupil Diameter), pode ser processada por meio do aprendizado dos sistemas padrão de reconhecimento e classificada em um dos estados emocionais do entrevistado. Os autores propõem uma instalação inicial do sistema para acessar e detectar os estados de estresse na utilização de um computador. Um sistema de detecção das reações chamado "Paced Stroop Test" foi desenhado para agir como estímulo para provocar estresse emocional do sujeito e com a utilização de técnicas de processamento para monitoramento e classificação dos estados de relaxamento e estresse é realizada uma análise utilizando três algoritmos para o tratamento dos dados: Nä̈ve Bayes, Decision Tree and Support Vector Machine. Na metodologia descrita o que se avalia é a atenção, engajamento emocional, retenção na memória, novidade, conhecimento e intenção de compra.

Alguns estudos do Instituto NeuroFocus são demonstrados na Ilustração 20. Nele são descritas diferentes possibilidades de aplicação do EEG e de técnicas biométricas. Para a Pepsico os estudos evidenciaram melhores embalagens para o público feminino; para a Intel descobriram a semelhança em posicionamento da marca em dois mercados mundiais: americano e chinês; para a CBS ajudaram a escolher a melhor opção entre projetos pilotos; para a ESPM mensuraram a melhor maneira de obter maior visibilidade para os 
patrocinadores; para o e-Bay buscaram identificar a melhor imagem corporativa e para uma marca de azeitonas Californiana, encontraram a embalagem mais atrativa.

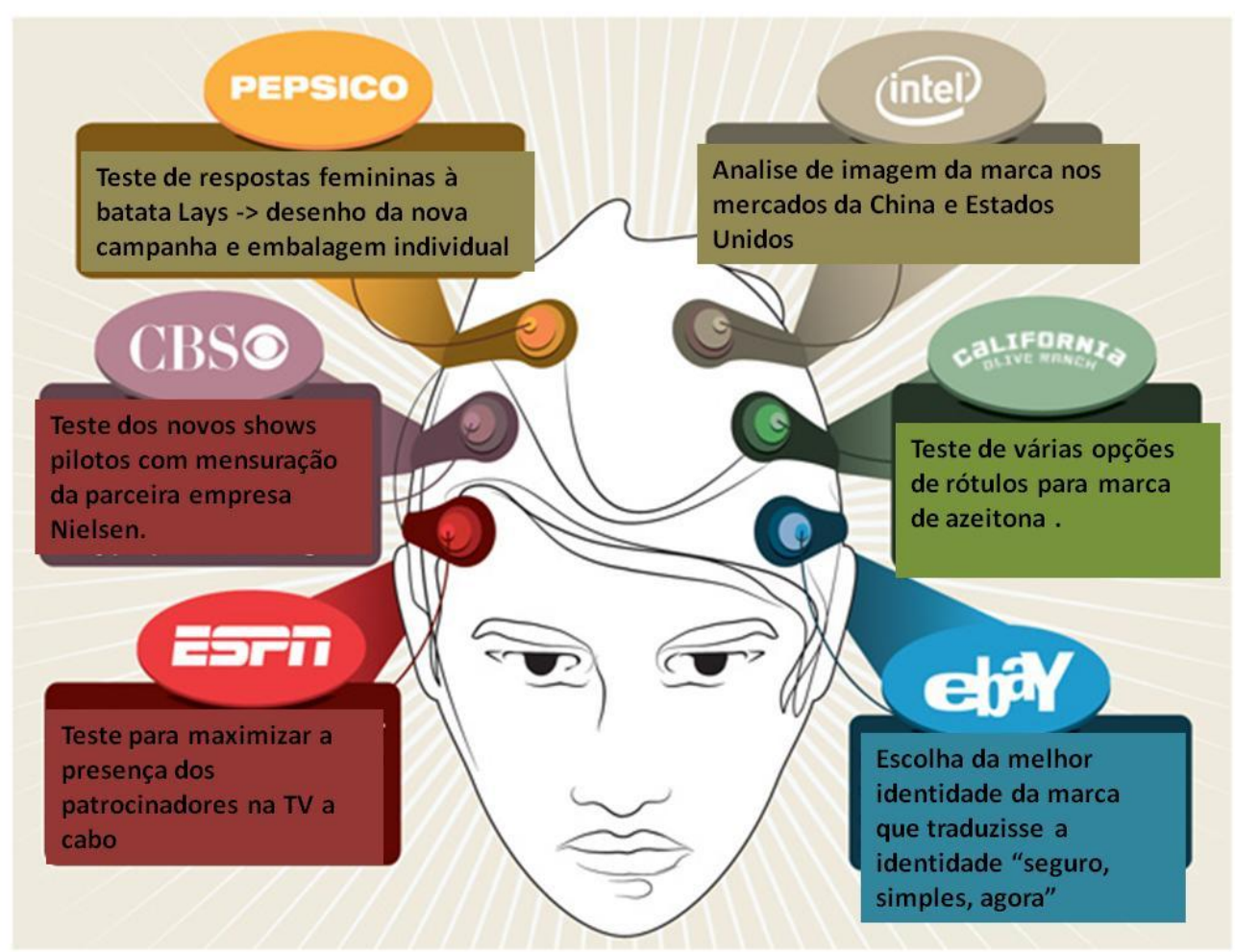

Ilustração 20 - Estudos de aplicação de EEG e biometria da Empresa NeuroFocus FONTE: NEUROFOCUS WEBSITE

Apesar de modernos modos de eletroencefalografia utilizados para marketing, acrescidos ou não de biometria, os projetos de investigação crescem a cada ano. Dados como atenção dos consumidores aos estímulos, seu grau de envolvimento emocional e também a extensão de transferência de dados na memória são áreas estudadas pelas empresas de pesquisa de mercado encontradas em vários sítios da internet.

A NeuroFocus chama suas técnicas de medição NeuroMetrics. Com suas métricas promete investigar em que grau o consumidor envolve-se com o estímulo, se há ou não envolvimento emocional, se há recordação do estímulo e se há intenção de compra. Com sua técnica obtém um calculo geral de efetividade ou Overall Effectiveness score, o qual é desenvolvido combinando todas as métricas do estudo e da qual derivam também outras três medições: intenção de compra, novidade e conscientização. A novidade mede o grau no qual o estímulo é destacado; a conscientização é o grau de entendimento da mensagem. A empresa acredita que das medições realizadas com o EEG provêm dados mais precisos, confiáveis e passíveis 
de ação. Por serem medidos em um estágio inicial da reação cerebral, os estímulos não são afetados ou influenciados ou ainda distorcidos por um fator externo. Entre as reações capturadas pelo EEG, a empresa afirma obter registro do estímulo por um ou mais sentidos; sua forma de reação inicial; sua formulação de resposta em forma motora (declaração ou algum movimento muscular). Ainda, pela mensuração da atividade da onda cerebral ser realizada duas mil vezes por segundo em medição total do escalpo, por meio de sensores sensíveis de EEG, evita a obtenção de ruído muscular de outros processos, consegue correlacionar com dados medidos por técnicas de eye tracking e outras mensurações biométricas, resultando em um detalhamento grande e do quão efetivo é o estímulo testado. Os resultados obtidos em um indivíduo podem ser extrapolados porque se acredita que os cérebros são mais parecidos do que diferentes. Apesar de algumas diferenças entre idade e sexo existirem, neurologicamente o cérebro é estruturado e funciona de forma uniforme e universal, apesar das diferenças de origens, nacionalidade, aprendizagem ou idioma que podem impactar resultados em pesquisas tradicionais de mercado. Acredita-se que as respostas do sistema biológico, ou biométrico, variam de indivíduo para indivíduo, portanto a complementação da medição fisiológica com a neural torna-se fundamental. A empresa concentra-se em estudos que envolvem marcas, produtos, embalagens, ações de ponto de venda e comunicação.

Para Fisher et al (2010) o neuromarketing tem recentemente gerado controvérsias envolvendo profissionais da área medica e muitas questões ainda existem, algumas delas com impacto na área da psiquiatria. Muitos conflitos envolvem as definições do neuromarketing e é pouco o que se sabe sobre as práticas atuais das empresas e de seus médicos e cientistas envolvidos nessa prática. Para os autores o neuromarketing é heterogêneo, as empresas estão oferecendo uma variedade de tecnologias para avaliar o comportamento. Muitas empresas estão empregando pessoas do meio acadêmico e profissionais reconhecidos, mas fornecem poucas informações acerca de suas técnicas e resultados, uma vez que não querem revelar seus clientes, suas questões estrategicamente secretas, suas recomendações técnicas em cada caso e também as taxas cobradas pelos serviços executados.

Os autores relatam que em uma busca pelo termo neuromarketing na WEB via buscador Google, obtiveram mais de 1000 soluções para o termo e 16 empresas oferecendo serviços na área. Resumidamente relatam que o termo é associado ao uso de técnicas de imagem como o fMRI, mas muitas empresas não utilizam imagem e baseiam-se em uma variada oferta de tecnologias ou em nenhuma tecnologia; somente algumas listam seus clientes, mas nenhuma 
lista seu custo; algumas descrevem suas metodologias e muitas de forma insuficiente; a maioria não oferece relacão de suporte com o meio científico do método utilizado ou qualquer ligação com alguma base acadêmica. O cenário relatado pelos autores ilustra a confusão sobre a definição disciplinar do neuromarketing, sua conexão com um campo acadêmico ou sua aplicação. Há também uma variação quanto a promessa de seu produto final, sendo que alguns relatam a entrega da verdade, ou seja, o que os consumidores realmente pensam ao invés do que dizem. Outros ainda afirmam que entregarão os diferentes tipos e níveis de emoção ou até mesmo o que a mente diz. A tabela 1 captura uma lista que contempla o resumo da oferta das empresas de neuromarketing pelas 16 empresas visitadas na WEB pelos autores:

Tabela 1 - Características de sites sobre neuromarketing

\begin{tabular}{|c|c|}
\hline $\begin{array}{cl}\text { Serviços oferecidos } \\
\bullet & \text { fMRI } \\
\text { - } & \text { EEG } \\
\text { - } & \text { Other } \\
\end{array}$ & $\begin{array}{l}31,2 \% \\
56,3 \% \\
75 \%\end{array}$ \\
\hline $\begin{array}{l}\text { Considerações de negócio: } \\
\text { - Custos } \\
\text { - Clientes }\end{array}$ & $\begin{array}{l}6,2 \% \\
25 \%\end{array}$ \\
\hline $\begin{array}{ll}\text { Descrição da Ciência } \\
\text { - } \\
\text { - } & \text { Publodologicação com revisão na WEB } \\
\text { - } & \text { Publicação com revisão por laboratório }\end{array}$ & $\begin{array}{l}81,2 \% \\
31,2 \% \\
25 \%\end{array}$ \\
\hline $\begin{array}{ll}\text { Profissionais empregados } \\
\text { - } \\
\text { - } & \text { MDadêmicos } \\
\text { - } & \text { PHD } \\
\text { - } & \text { Afiliados acadêmicos } \\
\text { - } & \text { Outras formações } \\
\end{array}$ & $\begin{array}{l}31,2 \% \\
31,2 \% \\
56,3 \% \\
6,2 \% \\
56,3 \%\end{array}$ \\
\hline $\begin{array}{l}\text { Formato do Site na home page } \\
\text { - Imagem do cérebro } \\
\text { - Imagem de funcionamento (EEG) } \\
\text { - Gráfico } \\
\text { - Outro gráfico ou imagem visual } \\
\text { - Um dos relatados acima } \\
\text { - Link de cobertura de midia }\end{array}$ & $\begin{array}{l}43,8 \% \\
31,2 \% \\
12,5 \% \\
18,8 \% \\
56,3 \% \\
56,3 \%\end{array}$ \\
\hline $\begin{array}{l}\text { Entregas/ Produto final } \\
\text { - Verdade/realidade } \\
\text { - Revelação dos segredos/subconscientes } \\
\text { - Predizer o comportamento futuro }\end{array}$ & $\begin{array}{l}62,5 \% \\
62,5 \% \\
6,2 \%\end{array}$ \\
\hline $\begin{array}{l}\text { Neuromarketing como melhora sobre outras técnicas } \\
\text { - Mitigar fatores } \\
\text { - Prover citações } \\
\text { - Ressalvas às tecnologias }\end{array}$ & $\begin{array}{l}50,0 \% \\
6,2 \% \\
37,5 \%\end{array}$ \\
\hline $\begin{aligned} & \text { Ética } \\
& \text { - Área especifica no site } \\
& \text { - Menção a palavra } \\
& \text { - Publicidade sobre assuntos } \\
& \text { - Riscos/benefícios descritos }\end{aligned}$ & $\begin{array}{l}12,5 \% \\
12,5 \% \\
12,5 \% \\
0\end{array}$ \\
\hline
\end{tabular}

FONTE: ADAPTADO DE FISHER et al, 2010, p. 233. 
Além da falta da homogeneização do termo neuromarketing, das técnicas de aplicação, do protocolo e resultados obtidos, outro fato que torna o tema ainda mais complexo é que a mídia ao redor do assunto é desproporcionalmente alta em comparação à escassez do material avaliado por pares em revistas científicas. Portanto, as empresas podem estar fazendo escolhas e anúncios prematuros com base no poder da neurociência em predizer o comportamento do consumidor. Além disso há o problema de limitação das tecnologias já descritas em relatos anteriores.

Um artigo de julho de 2010, na revista Harvard Review of Psychiatry, levantou mais preocupações sobre a forma simplista com que o neuromarketing conclui certos estudos, bem como com a falta de transparência em um campo cujas fundamentações acadêmicas são de difícil conclusão ou identificação. Neste mesmo ano, em setembro, o órgão regulatório de pesquisa Americano, The Advertising Research Foundation - The ARF , anunciou um projeto chamado NeuroStandards Initiatives, no qual participam oito empresas de pesquisa que utilizam a neurociência para investigações de mercado. Estas submeteram seus métodos para revisão com o objetivo de obter regras de utilização das técnicas de forma a criar guidelines ou procedimentos comuns, para validação dos resultados obtidos dentro do setor e evitar problemas ou discussões em relação à ética. A ideia é obter-se ao invés de cautela, segurança em relação aos novos procedimentos no mercado. O projeto chamado NeuroStandards, promete ser o primeiro e único conjunto de princípios científicos para aplicação de técnicas de investigação de mercado com utilização de EEG com forma de mapeamento do cérebro e determinará três segmentos fundamentais:

- Padrões para estudos de design, protocolos e processo de estabelecimento de amostragem estatística referenciais;

- Padrões para operações em laboratório, incluindo design especializado, técnicas de construção e materiais, grupo de especialistas, treinamentos, coleta de dados e seu gerenciamento e processos e procedimentos laboratoriais;

- Salvaguardas para manutenção de proteções rígidas para os consumidores, seus direitos e confidencialidade de seus dados.

A busca das normas é baseada no estabelecimento de pilares universalmente aceitos na área acadêmica, científica e também nas comunidades de negócio. Estas serão validadas por um grupo de pessoas da área médica, da neurociência, e também por princípio de qualidade 
estabelecido pelos princípios do Six Sigma e Total Quality management, princípios e práticas que garantem a aplicação e replicação dos estudos para outros casos futuros. De acordo com The ARF os padrões finais da NeuroStandards tem a intenção de prover um gerenciamento profissional para projetos de pesquisa de mercado e suas aplicações para as marcas, produtos, embalagem, pontos de venda e comunicação com um critério alto para desenho e condução de estudos de neuromarketing.

Os primeiros resultados desse trabalho colaborativo foram realizados com base em revisões de especialistas da área científica, chamados de Senior Review Panel, composto por especialistas em EEG e fMRI: Bob Berry - University of Wollongong, Australia; Rajeev Batra - University of Michigan; Steve Bellman - Murdoch University, Australia; Mark Frank University of Buffalo; Bill Gehring - University of Michigan;Scott Huettel - Duke University; Steve Luck - University of Texas; Russel Poldrack - University of Texas; Rob Potler University of Indiana; Leonard N Reid - University of Georgia; David Stewart - University of California Riverside; Dawn Sweet - Iowa State University e composto também por cientistas com expertise em neurociência como: Patrick Barwise - London Business School; Christopher Chabris - Union College/MIT; Annie Lang - Indiana University; René Weber University of California e liderança de Horst Stipp, membro do The ARF. O estudo também é composto por um grupo de empresas de pesquisa de mercado e algumas empresas comerciais que já fizeram uso de estudos de neuromarketing, como American Express; CampBells; The Clorox Company; Chase; Hershey’s; Colgate-Palmolive; GM; MillerCoors; ESPN; MTV Networks; Turner; NBCUniversal;Dentsu; Publicis Groupe, Warner Bross. A conclusão é que pesquisas de marketing que utilizam dados neurológicos e biométricos, constando deste grupo: MSW Lab, Sands Research, Innerscope, Gallup and Robinson, MindLab International LTD, Neuro-Insight, NeuroCompass, Sensory Logic, têm potencial de prover contribuição importante e válida no que se refere à avaliação de comunicação ou estímulos visuais. A fortaleza da utilização de métodos de neuromarketing se dá pela habilidade de prover um aprendizado relacionado à atenção, envolvimento e reações emocionais.

As descobertas de dada pesquisa, no entanto, não devem ser entendidas como cientificamente conclusivas no que se refere, por exemplo, a que o anúncio, ou outro estímulo irá necessariamente vender mais após receber boa avaliação. Acredita-se que progressos foram obtidos durante a última década nos estudos de neurociência e sua aplicação mercadológica, porém, há inúmeras questões e preocupações que envolvem esta área de estudo. 
Atualmente, conclui The ART, a nova disciplina chamada neuromarketing é uma combinação de arte e ciência e os usuários devem tomar cuidado em tomar seus resultados como um fato científico. Um dos desafios dos novos estudos é que materiais mais complexos como vídeo ou outras comunicações multissensoriais produzem uma gama complexa de estímulos que, além de trocar rapidamente de estímulos visuais como imagem, também acrescentam mudanças de palavras e música. Portanto, as reações oriundas de seus estímulos podem ser de difícil isolamento para entender as causas de dado comportamento.

Uma das vantagens da utilização de métodos neurobiométricos é a possibilidade de se obter respostas de segundo a segundo. No entanto, a complexidade dos estímulos combinado com a complexidade de leitura do cérebro humano representam os obstáculos de se obter resultados de leitura confiáveis em tal granularidade. Por exemplo, pode-se citar que diferentes imagens provocam reações com diferentes tempos de reação. A mente reage a imagens que refletem perigo, como a imagem de uma cobra, de forma mais rápida do que quando apresentada a imagens menos perigosas como a imagem de uma paisagem, sem dizer que a reação do indivíduo pode ser reflexo de sua antecipação da próxima imagem e não reflexo da imagem vista naquele momento. $\mathrm{O}$ aprendizado acerca dos tempos de reação devem ser aprofundados, buscando saber que :

- As reações a uma cena dentro de um comercial são susceptíveis de sofrer influência do conteúdo anterior. Interações entre as imagens, sons e palavras precisam ser separados para identificar as causas de resposta do observador.

- A complexidade do material de estímulo e dos comandos do cérebro humano devem ser combinados empregando modelos experimentais e recursos de outras pesquisas de design (como teste-reteste, rolo de anúncios, som on/off, reações a estímulos rápidos etc.) que aumentam a probabilidade de obtenção de dados válidos.

- A medição da atenção e reações relacionadas, como introduzir e retirar e excitação, é menos complexa que medir emoções específicas e intenção de compra. O consenso dos especialistas é que as reações a uma região específica do cérebro nem sempre podem ser interpretadas como indicativo de uma dada emoção.

No estudo em questão a maioria das empresas de pesquisa ressaltou que recomendam o uso de seus métodos como parte de um programa mais amplo de pesquisa e que o neuromarketing deve complementar e não substituir os métodos de sucesso. Também vale lembrar que 
nenhuma metodologia, incluindo aquelas tradicionalmente empregadas em pesquisa de marketing, oferece certeza absoluta e que todos os dados necessitam de interpretação e validação.

Há diferenças entre as empresas fornecedoras de estudos no campo de neuromarketing em termos de nível de evidência científica e validação para as medidas de fornecedores diversos. Alguns dos métodos e constructos utilizados são validados cientificamente em termos da literatura existente e de publicação da neurociência em avaliação por pares. Outros fornecedores demonstraram medidas proprietárias com uma alta correlação com os resultados de mercado, embora a ciência ainda não possa fornecer uma base clara para a interpretação de tais medidas.

O estudo recomenda que a indústria se comprometa em ampliar as pesquisas científicas e validação de métodos neuromarketing em linha com as recomendações saídas desse material, que definirá padrões para os usuários desses métodos de pesquisa, bem como para o vendedor.

A recomendação consiste em:

- Uso de métodos neurológicos e biométricos, como parte de um programa de pesquisa, como uma adição e não um substituto para-métodos "tradicionais";

- Os resultados desses métodos, apesar de valiosos, devem ser considerados como pontos de dados adicionais, não como resultado de um procedimento "científico" que está garantido para ser livre de erro e não requer nenhuma interpretação;

- Comerciantes devem aplicar as "melhores práticas" na escolha de um método de pesquisa. É sempre importante ser muito específico sobre o propósito da pesquisa, a fim de coincidir com um objetivo de pesquisa e o método. Os diversos métodos oferecidos no campo da pesquisa neuromarketing têm diferentes pontos fortes e fracos, nem todos são adequados para um dado objetivo da pesquisa;

- Usuário da pesquisa deve considerar o envolvimento de revisores acadêmicos independentes para ajudá-los a selecionar fornecedores e métodos adequados e revisar os relatórios finais.

- Problemas de qualidade tradicionais de pesquisa se aplicam à pesquisa neuromarketing da mesma forma como se aplicam a outros métodos: questões como 
tamanho da amostra e sua qualidade, a significância estatística dos resultados, e a presença ou ausência de controle experimental devem ser avaliados, mesmo que com o aumento do custo do projeto;

- Usuários da pesquisa e fornecedores devem trabalhar juntos para alcançar uma validação adicional dos métodos e gerar mais aprendizagem. Fornecedores são encorajados a fazer maior uso dos recursos presentes na literatura e na área acadêmica para fortalecer a base científica, bem como de seus métodos de pesquisa e acelerar o seu progresso.

Em suma, este é um campo novo com base na ciência e seus métodos que estão evoluindo. Usuários tendem a ganhar mais, se usarem essas novas ferramentas em conexão com os métodos estabelecidos e trabalharem com fornecedores para combinarem esses estudos com os objetivos da pesquisa e os métodos com grande cuidado.

O projeto vai levar a recomendações de melhores práticas para os usuários dessa investigação, bem como para os fornecedores. Além disso, embora seja evidente que mais trabalho precisa ser feito e que as várias questões ainda se mantêm abertas, também está claro que os pesquisadores do neuromarketing estão constantemente fazendo avanços em seus métodos e estão ganhando uma percepção mais profunda de sua experiência. O próximo passo será um Fórum NeuroStandards, bem como seminários especiais para os membros do The ARF para permitir que os patrocinadores do projeto, fornecedores e usuários da pesquisa apresentem e discutam sobre suas experiências e novas percepções. Uma meta importante será o desenvolvimento de padrões para neuromarketing. O Painel de Revisão Senior irá evoluir para uma rede de peritos independentes para ajudar os usuários de pesquisa neuromarketing. Cada uma dessas iniciativas será detalhada e sua publicação está prevista para o final do ano de 2011 .

Apesar da norma ainda estar em processo de validação, suas recomendações e conclusões foram utilizadas como insumo para determinar as contribuições do neuromarketing para os estudos de investigação do comportamento do consumidor. 
Próximos Desenvolvimentos

Depois de anos de acúmulo, o conhecimento humano está sobrecarregado de informações, recebe milhões de estímulos a cada minuto e tem que reagir a eles para fazer suas opções durante a vida. Na vida atual as viagens são inúmeras e mais rápidas, há mais mudanças de residências, muito mais pessoas conhecidas a cada minuto e, por muito menos tempo os relacionamentos se estabelecem. Há mais opções de produtos, serviços em diferentes estilos que o ano anterior em vários negócios, nos supermercados, nas lojas de carro, nos shopping centers e há expectativa de muito mais no próximo ano. Novidade, transitoriedade, diversidade e aceleração são descrições da existência da civilização atual. A avalanche de informações e opções é fruto do progresso tecnológico e suas variações na comunicação e estímulos e resta ao indivíduo a habilidade de guardar, recuperar e comunicar as informações recebidas diariamente. Mas as informações têm uma velocidade superior à capacidade natural de cada um processá-las. Portanto, quando da tomada de decisão, o indivíduo cada vez menos poderá levar em consideração uma análise total da situação e terá que focar, cada vez mais, na parte mais confiável ou familiar do todo, caso ela exista. Mas no caso de sua inexistência, a situação mais provável de decisão sem pistas será de tomar uma decisão errada. A correria da vida moderna demanda que o indivíduo tenha atalhos, dicas, para poder lidar com decisões imediatas e ajudá-lo da forma mais efetiva possível (CIALDINI, 2007).

A constatação é que os comportamentos automáticos dependem apenas de informações ascendentes, enquanto os comportamentos inteligentes ou controlados acrescentam informações descendentes ou top-dowm que expressam nossa vontade, nossos pensamentos e nossas emoções. Dada a complexidade que caracteriza o controle cognitivo é fácil admitir que ela exija uma eficiente coordenação entre áreas e processos cerebrais, dependentes de circuitos que interligam muitas partes do cérebro. Para que essa complexa coordenação ocorra, é necessário dispor de um integrador principal, uma região cerebral que desempenhe o papel de pólo de convergência ou hub, que é chamada de córtex pré-frontal, responsável por nosso comportamento inteligente. Este se comunica com diversos sistemas sensoriais que processam dinamicamente a informação que vem do ambiente, e também com sistemas motores que planejam e comandam nossos atos voluntários e involuntários, além de selecionar informações, o que ocorre com a atenção. Gerenciar no tempo esse fluxo constante de informações, o que caracteriza a memória operacional, e realizar essas operações de modo flexível é o principal papel dessa região cerebral. (KANDEL et al, 2000). Os autores pontuam 
que há progressos em anos recentes no entendimento de como os sistemas gerenciam o fluxo constante de informações para gerar um comportamento.

Houve o desenvolvimento de técnicas de registro simultâneo de grandes populações de neurônios e do sincronismo ou dessincronismo de sua atividade, o que tem permitido a criação de neurorrobôs, dispositivos mecânicos comandados por computadores, que por sua vez são alimentados pelo pensamento. A atividade da população neuronal associada à execução daquela tarefa comportamental é transferida ao neurorrobô pelo computador e este executa a tarefa que seria realizada pelo corpo do indivíduo. Como mostra a Ilustração 21, os pesquisadores captam por meio de microeletrodos inseridos no cérebro do macaco a atividade elétrica simultânea de grande número de neurônios encarregados da programação motora do braço. Depois há a análise por um computador e os padrões obtidos são utilizados para movimentar um braço robótico.

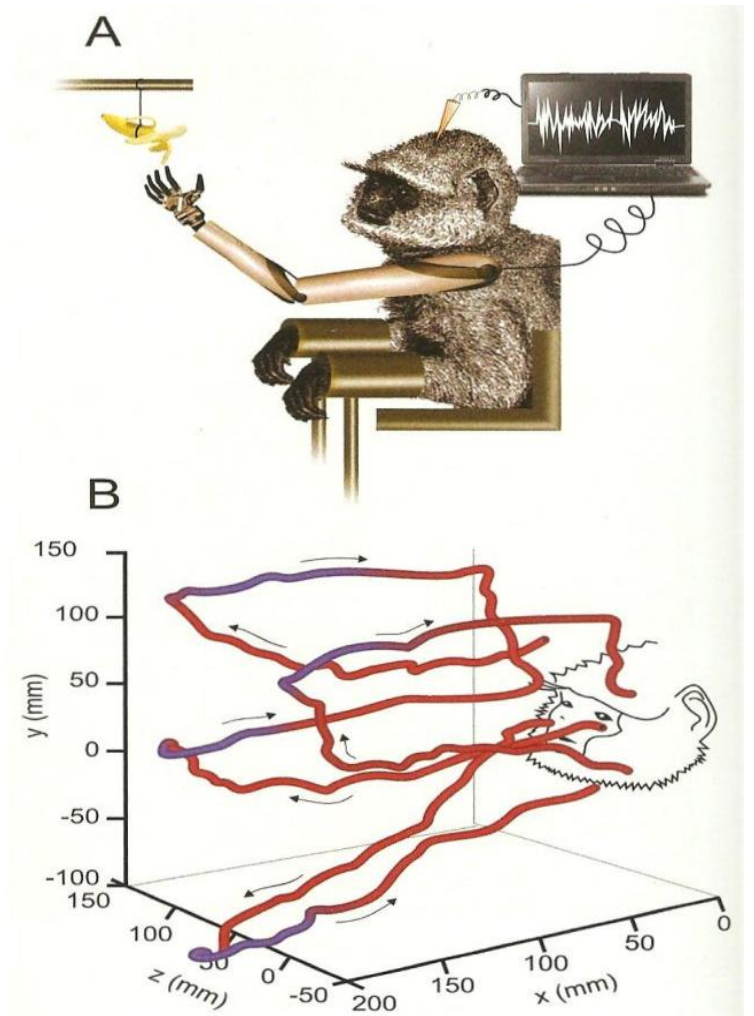

Ilustração 21 - Experimento com mapeamento de neurônios e aplicação em robôs. FONTE: LENT, 2010, p. 24.

Os dados obtidos por meio de neuroimagem funcional têm apontado recentemente para aspectos conceituais novos que anteriormente não eram enfatizados: a razão e emoção não constituem funções mentais independentes, mas sim altamente integradas e inter-relacionadas; a extensa integração entre as duas funções extrapola suas próprias e, na verdade, revela uma 
integração ainda maior com outros aspectos da atividade mental como linguagem, memória, e comportamento. Na vida cotidiana, em face de determinada situação, há geralmente uma cena real ou imaginária que é avaliada com base inicialmente em informações sensoriais sejam estas visuais, auditivas e outras. Esse conjunto de informações sensoriais é comparado com os arquivos situados na memória e ponderado segundo seu significado emocional. Com base nesse conjunto de dados é avaliado o custo/benefício e a devida previsão sobre os prováveis resultados das ações, para finalmente ser tomada uma decisão que orientará o comportamento. Uma complexa sequência de computadores que possibilita o comportamento e que envolve áreas de muita complexidade e processos individuais de significância.

Como enfatizado por Kandell et al (2000), a neurociência e a psicologia cognitiva finalmente encontraram agora uma base comum e dessa forma começa a haver benefício do crescente poder explanatório que resulta da convergência dessas disciplinas inicialmente díspares. As recompensas dessa fusão entre as diferentes áreas são particularmente evidentes nos estudos de aprendizagem e memória e, por consequência, do comportamento individual.

\section{O Futuro do Neuromarketing}

Algumas direções para novos estudos são oferecidos por Lee et al (2007). Para os autores, as técnicas de neuroimagem poderiam iluminar alguns assuntos importantes, com especial atenção para um nível de perguntas a não consumidores na tentativa de aumentar o escopo do debate da aplicação da neuroimagem à pesquisa de mercado. As áreas que citam para o desenvolvimento futuro a ser explorado é a confiança como ferramenta de utilidade social sobre o que seria "justo" em uma negociação ou organização; o pricing, ou precificação do produto e o entendimento da psicologia dentro de diferentes contextos e do ambiente social; a negociação onde há áreas como a experiência de desprazer deve ser explorada bem como interações em situações onde há diferenças de retorno em diferentes situações e suas estratégias.

Para Spiers e Maguire (2006), a mente humana evolui para sobreviver em um ambiente de estimulação constante, complexa e de mudanças rápidas. Tentativas de averiguar os substratos neurais quando operam em contextos naturalistas representa um enorme desafio. Uma abordagem tem sido a de examinar estímulos simplificados ou abstraídos de forma controlada por meio de ressonância magnética em estudos experimentais. No entanto, informações 
importantes podem ser perdidas por não examinar os pensamentos e comportamentos no ambiente do mundo real, onde normalmente ocorrem. Novas abordagens como as descritas requerem mais trabalho para melhor compreender, avaliar e otimizar a sua utilização em uma variedade de domínios mais amplos da neurociência cognitiva. Outras metodologias também podem ser úteis para examinar a atividade do cérebro durante a visualização de estímulos dinâmicos naturalistas, e a inclusão de medidas fisiológicas, tais como condutância da pele, frequência cardíaca e os movimentos dos olhos podem refinar ainda mais a compreensão. Entretanto, a combinação de estímulos naturalistas com os métodos de análise aqui descritos não é trivial. Os autores sugerem que o trabalho futuro a este respeito deva ser dirigido para abordar questões difíceis ou mesmo impossíveis com a utilização de estímulos estáticos, e citam como exemplos de benefícios : para o entendimento das interações sociais, como se aprende a encontrar caminho em novos ambientes, para a formação de memórias autobiográficas e processos de decisão em contexto de estimulação complexa. Assim, os esforços de muitos neurocientistas cognitivos podem enriquecer ainda mais com a inclusão de novos métodos em seu arsenal.

A. K. Pradeep, fundador e presidente da empresa de pesquisa NeuroFocus do grupo Nielsen Holdings, com base na universidade de Berkeley, California, afirma na Revista Fast Company dispor de ferramentas para captura do significado dos estímulos cerebrais causados pelo marketing, trazendo à tona o subconsciente dos estímulos das marcas e sendo assim mais preciso nos resultados que as pesquisas com utilização de focus groups ou outras ferramentas tradicionais de pesquisa de mercado de consumo. Em agosto de 2011 inaugurou uma inovação em eletroencefalograma chamada Mynd, um escâner ou EEG, com vários sensores instalados em um aparelho do tamanho de uma calota craniana que cobre toda a área do cérebro, conforme a Ilustração 22 . Promete com sua aplicação, capturar ondas sinápticas de maneira fácil e prática, expedir os resultados das ondas em tempo real via bluetooth para um aparelho remoto, como um telefone celular, enquanto o indivíduo interage em seu ambiente natural diário, vendo televisão, cinema, teatro ou fazendo compras em um supermercado. Por meio de painéis com consumidores americanos a empresa coletará os resultados dos dados e analisará as respostas subconscientes dos participantes às propagandas, aos produtos, marcas e mensagens. 


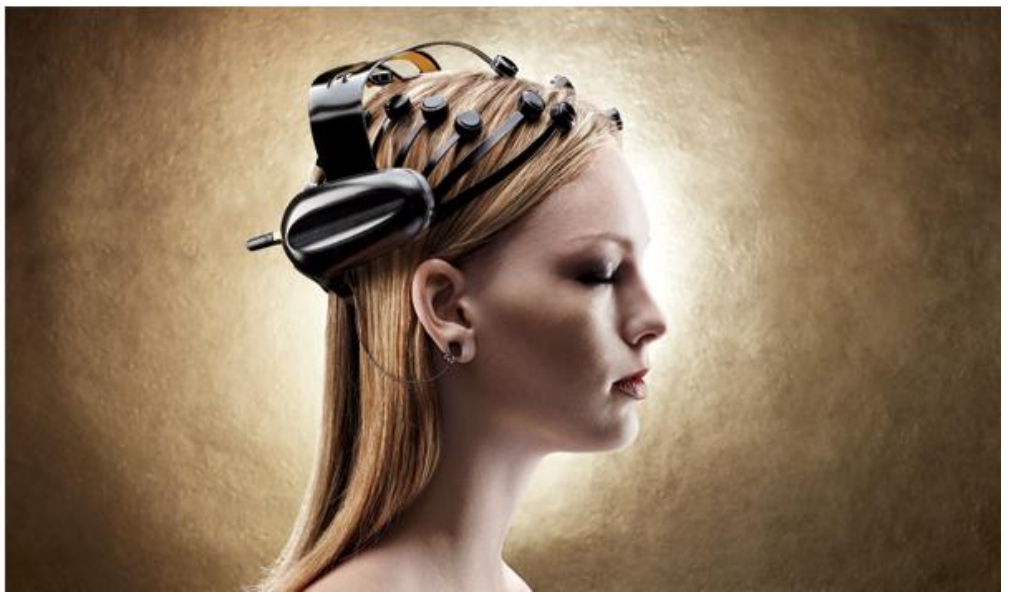

Ilustração 22 - Mynd, o EEG do futuro

FONTE: REVISTA FAST COMPANY, 2011,

www.fastcompany.com/magazine/158/neuromarketing-intel-paypal.

Com a utilização do eletroencefalograma medindo as ondas elétricas da superfície do cérebro em tempo real, em um ambiente real de vivência, acredita-se que os dados não são filtrados ou corrompidos por formulações conscientes advindos da miríade dos mecanismos mentais, da memória, educação, valores sociais e culturais, que formulariam respostas verbais ou outras articulações. Com a detecção das ondas e suas áreas específicas do cérebro busca-se relacionar a reação com emoção, memória ou atenção ou respectivamente, amídala, hipocampo ou córtex pré-frontal. Pradeep afirma que o método é mais efetivo e preciso, além de mais barato que as pesquisas tradicionais, se comparado com a imprecisão dos resultados destas, que apontam cerca de $80 \%$ de insucesso no lançamento de novos produtos no mercado e seus investimentos altos. Isto porque acredita que o cérebro das pessoas é semelhante, com algumas variantes definidas por sexo e idade.

A revista Science de agosto de 2011 trouxe uma nova maneira de medir os sinais elétricos dependentes de desconfortáveis eletrodos e gel condutores de eletricidade, chama-se sistema epidérmico eletrônico ou EES. Basicamente, é uma forma de dizer que o aparelho combina propriedades físicas da pele, como rigidez e densidade, por meio de tatuagens temporárias. Feito de silicone e células que geram eletricidade, o adesivo é solúvel e pode capturar dados por seis horas. Pode ser usado por 24 horas, sem degradação ou irritação da pele, como pode ser visto na Ilustração 23. Além disso, melhorias na duração de sua validade estão sendo realizadas para poder futuramente utilizar energia solar para seu funcionamento. 


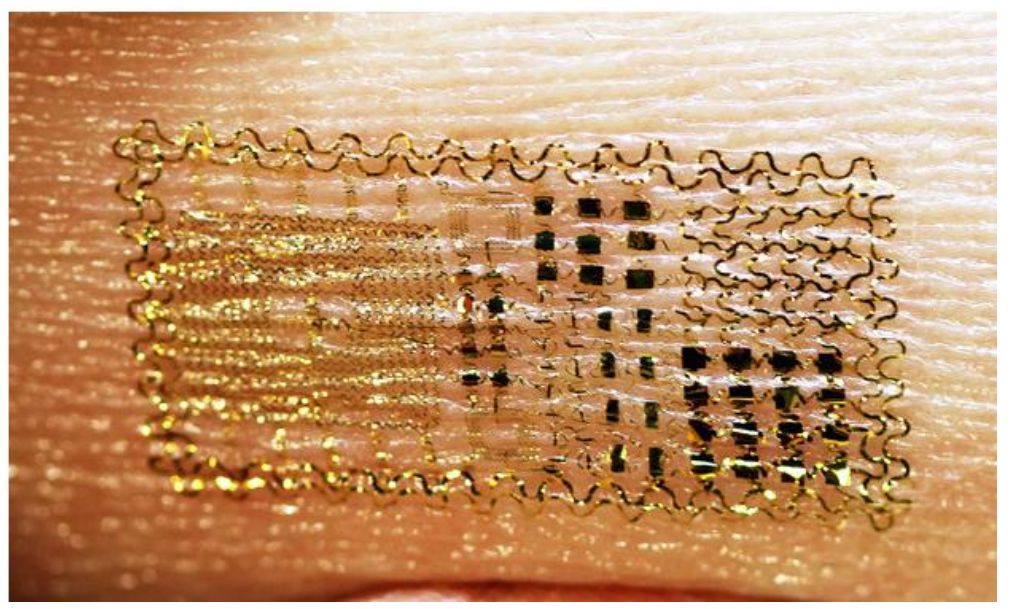

Ilustração 23 - O sistema epidérmico eletrônico

FONTE: REVISTA SCIENCE, 2011

http://arstechnica.com/science/news/2011/08/temporary-tattoo-electronics-flexible-ultrathinmeasurement-devices.ars

Os futuros desdobramentos do neuromarketing estão sendo rápidos. Primeiramente a neurociência está gerando novas descobertas sobre o cérebro humano a todo o momento, grandes progressos estão acontecendo em muitas áreas de forma simultânea, afirma a NeuroFocus. Uma nova área de especial interesse é o BCI (Brain Computer Interface), que nada mais é que o conhecimento do circuito do cérebro combinado com um avançado computador que cria meios de se combinar com os dados para ajudar a superar a falta de entendimento dos dados ou síndrome do "locked-in". Na área comercial desta ciência recentemente foi inaugurada a primeira loja virtual com experiência 3D ou tridimensional. Chamada $N$-Matrix $3 D$, oferece às empresas a capacidade de testar respostas subconscientes a vários tipos de estímulo, de design de embalagem a displays de ponto de venda, layout de loja, sinalizações, materiais de promoção, tudo em um ambiente hiper-realista desenhado para que a mente consiga detectar o ambiente como estímulos reais e autênticos, tal qual a pessoa teria em uma ambientação na vida real em uma loja. Além da simulação e medição de estímulos virtuais, esse tipo de teste permite ganhos de custos reais, pois ao mesmo tempo consegue demonstrar estímulos realistas e resultados possíveis de obtenção somente com a utilização de algo virtual. Outra inovação será a utilização de uma tecnologia wireless, isto é, a utilização de um novo EEG baseado nos estímulos em todo o escalpo que proverá uma precisão científica ainda maior por oferecer maior flexibilidade por meio da mobilidade na experiência. 


\section{As Questões do Neuromarketing}

No entanto, ainda há uma série de dúvidas a respeito dos resultados das investigações do cérebro, principalmente por oferecerem várias possibilidades de correlações e interpretações de seus dados e também por trazerem à tona uma série de questões a respeito das aplicações e replicações do conhecimento. A extensão da área de pesquisa em uma nova área multimétodos pode enriquecer a habilidade de entendimento exato do como as pessoas cooperam ou não, mesmo em situações onde este comportamento possa ser ótimo.

As três principais razões pelas quais o marketing se interessa em entender o subconsciente são: pelo interesse inicial pelo produto; pela compra e sua intenção e lealdade; compreender as possibilidades de repetição do comportamento, o reforço por experiências boas ou a minimização de suas frustrações. O cérebro é uma série de redes neurais, suas estruturas e regiões onde funções múltiplas e interconectadas ocorrem ainda estão em um grau incompreensível.

Para Schiffman e Kanuk (2000) as pessoas com necessidades diferentes podem buscar a satisfação por meio da seleção dos mesmos objetivos; as pessoas com as mesmas necessidades podem buscar a satisfação através de objetivos diferentes. Evidencia-se assim a necessidade de acréscimo de diferentes áreas do saber na busca por informação sobre estudos e pensamentos da neurociência cognitiva aplicada ao mercado para enriquecer o discurso apresentado até o momento neste estudo.

Como afirma Lindstrom (2008), de forma alguma os consumidores podem expressar algo que realmente pensam de forma consciente. As reações e emoções são encontradas no cérebro em um curto espaço de tempo e não de forma consciente traduzida em palavras descritas em um questionário, e, portanto há o descrédito nas investigações tradicionais utilizadas para investigar construção de marca. Castells (2009) comenta que a construção da realidade para uma pessoa, como reação a eventos internos ou externos, se dá com o processamento dos mesmos de acordo com padrões individuais. A maioria dos processamentos é inconsciente e a realidade não é objetiva nem subjetiva e sim fruto da construção de imagens que misturam o que acontece no mundo físico (dentro e fora do indivíduo) com o material da experiência anterior acumulada na mente no decorrer de correspondências neurais no tempo, entre as características dos eventos e o catálogo de respostas disponíveis na mente. Estas experiências 
são construídas, por exemplo, com uso de metáforas. A consciência pode ocorrer quanto mais integrado for o material percebido com aquele que está acumulado na memória do indivíduo. A consciência opera em um processo do cérebro. A integração das emoções, sentimentos e raciocínios, acabam levando à tomada de decisão que determina esse processo. Representações mentais tornam-se mecanismos de significado quando incorporam emoção, sentimento e raciocínio, que definem a forma de viver. $\mathrm{O}$ entendimento deste mecanismo é necessário para que se compreenda o que atualmente significa quando se fala o que fazer quando alguém quer fazer algo. Emoções, sentimentos e raciocínio são originais do mesmo padrão neural entre cérebro e corpo e seguem as mesmas regras de associação e representações multicamadas que caracterizam a dinâmica da mente.

Para Ariely e Berns (2010) é complexo dizer que o método fornece a medida mais verdadeira em termos de decisão utilitária, ou seja, no mercado onde irá atuar o produto. Está claro que o mercado teste fornece o resultado mais preciso, mas ter que realizá-lo em cada produto de uma empresa seria anular o propósito da pesquisa de mercado. Os autores suspeitam e os economistas estão seguros que os métodos que têm incentivos compatíveis são melhores que os que não oferecem nenhum. Quando há incentivos que encorajem o participante a revelar realmente o que está sendo perguntado, ele o fará, pois isso maximizará sua satisfação ao ganhar mais dinheiro ou receber o produto de sua preferência. Em outras palavras, é do interesse do participante responder perguntas relacionadas a produtos de forma verdadeira, no entanto, a utilização deste tipo de método nem sempre é possível. Uma importante questão para o potencial do método de neuromarketing é se o sinal neural, na hora ou levemente antes da decisão, pode ser um bom preditor de prazer ou recompensa da hora do consumo. Uma segunda questão é se a ligação entre dois sinais continua o mesmo quando os métodos de elicitação de preferência não são compatíveis aos incentivos. Se for possível responder positivamente as duas questões citadas, o neuromarketing poderá ser útil para medição de preferência. Um exemplo mencionado é o de estudo medido com fMRI, onde os entrevistados apostavam pelo direito de comer salgadinhos e com isso acionavam o córtex medial e também o córtex pré-fontal. Ativação similar aconteceu quando os entrevistados antecipavam uma sensação de prazer, olhavam faces de pessoas bonitas, ouviam música de sua preferência ou mesmo recebiam dinheiro. Essa correlação entre áreas em atividade cerebral em antecipação por recompensa e o consumo de coisas prazerosas podem ser devido aos sistemas que avaliam a qualidade da experiência de consumo. $\mathrm{O}$ fato sugere que a neuroimagem pode tornar-se uma ferramenta útil para medir preferências, particularmente quando ouver incentivo de forma a 
tornar-se uma proxy para situações onde há possibilidade de ganho. Outra utilidade para utilização de ativação da mente, de acordo com os autores, é em estudos de desenvolvimento de produtos onde se busca entender preferências entre as opções. A utilização de ressonância magnética funcional pode potencialmente estar presente em dois lugares por entender-se que independentemente de como uma mente individual representa a informação, o fato ocorre consistentemente, mesmo que de forma diversa entre indivíduos e pode ser detectado utilizando-se análise de padrões de atividades distribuídas, um método estatístico envolvendo padrões que ocorrem quando um indivíduo tem uma ativação complexa em seu processo de decisão - MVPA (multi-voxel pattern analysis). Primeiramente, pode ser usado como parte do processo de design, onde a resposta neural pode definir o produto antes do lançamento. Em um segundo momento, a ressonância pode ser usada após o produto estar desenhado, para medição de resposta em uma campanha de comunicação para aumentar as vendas. O processo pode ser resumido conforme imagem da Ilustração 24 :

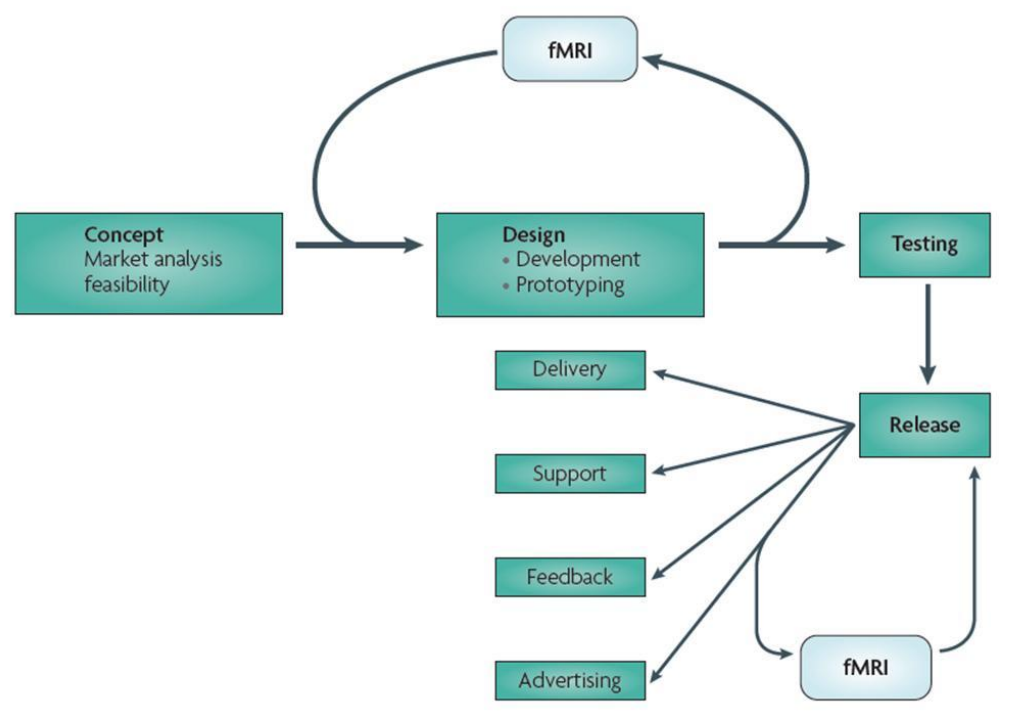

\section{Ilustração 24 - Ciclo de desenvolvimento de produto FONTE: ARIELY; BERNS, 2010, p. 286.}

Para os autores há possibilidade de obtenção de maiores informações, caso instrumentos analíticos como MVPA sejam utilizados para combinar maiores dados da imagem e suas correlações para entendimento do comportamento. No entanto, o ganho na fase de design e pós-teste de comunicação, onde a resposta aos estímulos é medida, pode ser de grande valia. No entanto, a existência de um botão de compra no cérebro, aparentemente é uma forma simplista de entender um processo cognitivo associado a decisão de compra, pois este é multifatorial e não pode ser reduzido a uma simples área ativada. 
Para Fisher et al (2010) é prematura a conclusão de um botão de compra ou local mágico a ser acionado para obter sucesso em marketing, pois as tecnologias disponíveis em imagem não oferecem precisão e previsões determinantes no processo de decisão humana.

Reciprocamente, uma dada região pode envolver uma ação cognitiva múltipla. O processo de decisão é complexo, como já descrito no modelo de Schiffman e Kanuch (1997). De acordo com Ariely e Berns (2010) os processos de decisão podem ser divididos em categorias: representação de uma decisão; atribuição de valor a diferentes ações; seleção de ação; pósavaliação e aprendizado. Os dados atuais sugerem que respostas aos esforços de marketing e escolhas do consumidor dependem de uma gama de processos biológicos e não somente a ativação de uma área cerebral, com possibilidade de estarem algumas regiões mais ativas que outras em específicos processos. Como exemplo, os processos de recompensa, em estudos neuroeconômicos onde se encontram vários dados de mecanismos e associações de regiões envolvendo dopamina. Em processos envolvendo objetivos observam-se regiões órbito frontal e estriatum. A ínsula é presente para excitação fisiológica. Walter et al (2005) demonstraram que a ínsula está envolvida quando uma pessoa experiencia negativamente eventos sociais como ser tratado de forma injusta, ser frustrado, ser excluído ou ver outras pessoas sofrerem, portanto, pode-se afirmar que aparentemente a dor mental pode ser relacionada com a dor física, originada em várias atividades distintas, em termos neuroanatômicos. Segundo, que estas reações emocionais podem ser influenciadas e controladas por regiões do córtex préfrontal. Por último, a neurociência aponta para o fato de que as medidas de punição também estão relacionadas com as experimentações de recompensa. Assim, considerar que atividades prazerosas estão na região órbito frontal e que a ínsula é medidora de repugnância é muito simplista para um uso na vida real se somente utilizadas os resultados de neuroimagem sem combinação com outras métricas de preferências.

O EEGs, por exemplo, pode ser utilizado para determinar se a pessoa está envolvida, mas não consegue decifrar as nuances deste envolvimento, de acordo com Dr. Robert T. Knight, professor de neurociência e psicologia de Berkeley e parte do conselho científico da empresa NeuroFocus. Isto significa que neuromarketing pode distinguir se uma resposta emocional é positiva ou negativa, mas não consegue saber se a resposta positiva é admiração ou diversão, isto é, seu real significado. (New York Times, Agosto, 2011).

Neuromarketing pode ser visto como uma extensão da pesquisa para a quantificação e a certeza nos aspectos anteriormente indefinidos do comportamento humano. Certamente, como 
Walter et al (2005), o debate público traz medos e esperanças que são mais do que justificáveis pois, mesmo que seja verdade que qualquer técnica pode ser abusiva, há que se ter em mente que, primeiro, o comportamento é influenciado por muitos fatores que são impossíveis de se reproduzir em laboratório; segundo, é pouco provável que um grande grupo de pessoas serão estudadas por neuroimagem, criando assim um banco de dados que vá além do conhecimento básico de pesquisa e que possa ser utilizado em uma análise de negócio passível de conclusões; terceiro, por limitações de metodologia não é possível medir atividade cerebral se as pessoas não quiserem fazer parte do estudo; por último, o problema ético não é específico da neurociência, mas sim uma questão que pertence a todo estudo de marketing.

\section{A Questão da Ética no estudo de Neuromarketing}

Para Farrel (2003) o assunto ainda levanta questões não esclarecidas em relação à ética. As corporações, os mercados de ações, os políticos, podem transformar os dados obtidos em resultados neurológicos em armas para acionar a mente dos consumidores como um processador sem uma proteção antivírus, uma arma de ilusão de massa.

Portanto, de acordo com o autor, o neuromarketing tem implicações importantes na parceria entre a academia e a indústria, desde a responsabilidade da condução na pesquisa até o oferecimento de um maior entendimento ao público sobre o funcionamento cerebral.

Os receios relacionados à ética garantem as empresas de pesquisa de mercado que, desde que os indivíduos concordem em participar, e tenham a palavra final sobre a utilização nos dados obtidos em seus exames, não haveria maiores problemas nesta nova ciência se comparada aos métodos tradicionais. No entanto, há diferença entre as empresas incentivarem as pessoas em participarem de seus estudos de forma declarada, por meio de utilização dos dados de navegação em seus websites e compartilhamento dos dados pessoais se comparados com um estudo utilizando EEG para elaboração de anúncios, ou qualquer outra proposição de produto ou serviço que é feito sem a conscientização real de sua utilização futura. A neurociência oferece benefícios para o paciente e também para o consumidor, contanto que haja vigilância e adesão às leis que oferecem proteção ao abuso do cidadão. 


\subsection{Conclusão - Resumo das Contribuições da Neurosciência dentro do Estudo do Comportamento}

A fascinação pelas imagens relacionadas aos estudos do cérebro atrai e direciona atenção, não somente entre estudiosos, mas também na população em geral. Primeiramente porque como menciona Thornton (2011) as imagens encorajam a pensarmos em absolutamente tudo por meio da mente ou em termos dela. O que se vê hoje na mídia é que as imagens rotulam a mente em feliz, triste, focada. Isto reforça que tudo, de sentimento, emoções, hábitos até exercícios são medidos e vistos por meio de mudanças nas imagens do cérebro. $\mathrm{O}$ fato sugere que o cérebro pode ser calculável, medido, e que todas as suas reações são passíveis de mudança, contanto que se tenha suficiente conhecimento do assunto. As imagens, no conhecimento comum, ensinam que pode ser relativamente simples ter um mapa ou imagem que demonstra precisamente o que ocorre, onde ocorre e, em sua extensão, o que está acontecendo, aumentando a persuasão ao promover o senso de intervenção de maneira precisa na mente para a obtenção de um resultado esperado. O que se esquece, no entanto, é que o cerebro é um dos objetos mais complexos do universo e a fronteira final da ciência moderna, dentro da crença que, uma vez conhecendo a mente pode-se saber o todo, o que se pode saber da natureza humana, e com isso estabelecer o controle sobre tudo e todos. Portanto, de acordo com o autor, a busca pelo conhecimento e detalhamento da mente, transforma-a num órgão prático, uma máquina que se pode aproveitar e moldar para intermináveis autoaperfeiçoamentos, seja por substanciar o determinismo biológico, como a mente ser responsável por tudo o que se faz, ou para apoiar reivindicações que enfatizam o ato individual e responsabilidade de comportamento para garantia da sauúde do cérebro. Mas, apesar das imagens da mente carregarem peso de autoridade na ciência, seus significados como input científico são válidos, mas não oferecem uma clareza ao público na maneira que podem ser ainda utilizados como suporte imediato. O funcionamento do cérebro não é simples e natural, e sim mediado na maneira que se conhece, entende e visualiza os estímulos e também é moldado pelo contexto social, político e econômico ao qual o indivíduo pertence e convive.

Ficou claro, até o momento, que há uma diferença entre os artigos acadêmicos encontrados sobre neuromarketing versus o que se observa entre os estudos de comportamento do consumidor em prática no mercado. Ainda, que há também diferenças entre os métodos 
utilizados comercialmente, ou seja, existe uma diversidade de conceitos técnicos e as aplicações encontradas na ciência e na prática. Nos estudos acadêmicos o método encontrado para investigação das reações cerebrais aos estímulos são medições in loco, de forma estática, na sua maioria em laboratório, com diagnósticos utilizando técnicas de medição no cérebro, de imagem e elétricas. Nos estudos trazidos pela literatura das práticas empresariais dos institutos de pesquisa, no entanto, o que se vê em sua maioria é uma combinação das técnicas de medição elétricas, utilizando EEG, mas também fisiológicas, isto é, medição das reações aos estímulos por meio dos efeitos de mudanças elétricas, químicas e mecânicas no corpo do indivíduo, combinando instrumentos de medição de íris e pupila, reações na pele, alteração de batimentos cardíacos e também movimentação elétrica no escalpo, bem como complementação com técnicas tradicionais de questionários. Algumas empresas também oferecem estudos simuladores de situações reais em ambiente virtual e outras oferecem medições enquanto os indivíduos vivenciam a experiência por meio de EEG e outras medições mais adaptáveis ao corpo humano. No entanto, como os estudos das empresas em sua maioria é confidencial, uma vez que busca soluções para empresas em seu ambiente mercadológico, o que ocorre é falta de análise dos protocolos, procedimentos e avaliações dos estudos, ou seja, há dúvidas sobre a confiabilidade de seus achados.

Aparentemente, o que a iniciativa do projeto colaborativo em realização pela Advertising Research Foundation, The ARF, está buscando é a validação, estabelecimento de procedimentos e principalmente visa a colaboração de equipe múltipla, com presença de empresas, institutos de pesquisa e cientistas para estudo do comportamento. No entanto, por ser composta por um painel limitado a seus contribuintes, ainda não é conclusivo e necessita de maior conhecimento para sua validação entre seus pares.

$\mathrm{Na}$ busca por elucidar as diferentes contribuições de pesquisas de comportamento, suas principais características, dificuldades e ganhos em sua utilização durante um processo de marketing, buscou-se complementar uma tabela existente em Ariely e Berns (2010) com as diferentes áreas de estudo de comportamento exploradas na presente dissertação. Há o destaque da contribuição de cada uma delas para o estudo do comportamento do consumidor em suas três fases principais descritas por Schiffman e Kanuk (1997): a fase de input, experiência e output. Foram descritas com base na revisão bibliográfica, onde se buscou detalhar o que se mede, o tipo de processo de resposta, a utilização típica, os custos e riscos envolvidos, as habilidades necessárias para sua implantação, as fases adequadas onde 
contribui no marketing e também em que fase melhor se adequa na busca pelo entendimento do processo decisório. A intenção da construção da Tabela XX é, após descrição do processo complexo de decisão, oferecer uma complementação às técnicas tradicionais, com os benefícios entendidos da utilização de novas metodologias como a semiótica, as ciências cognitivas, bem como o aprofundamento da investigação do neuromarketing. Como já foi mencionado anteriormente, qualquer que seja a alternativa escolhida, ela por si só não oferecerá um diagnóstico exaustivo para a pergunta do problema. Recomenda-se o uso em conjunto com outras metodologias, sempre levando em conta a particularidade de cada uma, seja pela especificidade da amostra, coleta de dados, análise dos mesmos e as conclusões com as devidas ressalvas, buscando sempre seguir a ética e os detalhes de cada mercado. Mais detalhes no Quadro 7. 
Quadro 7 - Diferentes métodos de investigação do comportamento, fases de decisão e suas contribuições

\begin{tabular}{|c|c|c|c|c|c|c|c|}
\hline & Focus Groups & $\begin{array}{l}\text { Questionário } \\
\text { de } \\
\text { preferências }\end{array}$ & Simulação & $\begin{array}{l}\text { Teste de } \\
\text { Mercado }\end{array}$ & Semiótica & $\begin{array}{l}\text { Ciencia } \\
\text { Cognitiva }\end{array}$ & Neuromarketing \\
\hline $\begin{array}{l}\text { Oquéé } \\
\text { medido }\end{array}$ & $\begin{array}{l}\text { Respostas } \\
\text { abertas, } \\
\text { linguagem } \\
\text { corporal e } \\
\text { comportament } \\
\text { o:nãó é } \\
\text { adequado para } \\
\text { análise } \\
\text { estatística }\end{array}$ & $\begin{array}{l}\text { Ponderação } \\
\text { para vários } \\
\text { atributos de } \\
\text { produto }\end{array}$ & $\begin{array}{l}\text { Escolha entre } \\
\text { produtos }\end{array}$ & $\begin{array}{l}\text { Decisão para } \\
\text { compra e } \\
\text { escolha entre } \\
\text { produtos }\end{array}$ & $\begin{array}{l}\text { Declarações } \\
\text { de } \\
\text { sentimentos, } \\
\text { pensamentos, } \\
\text { idéiase } \\
\text { ideologias }\end{array}$ & $\begin{array}{l}\text { Investigação } \\
\text { da cognição, } \\
\text { consciente e } \\
\text { inconsciente } \\
\text { aos estímulos }\end{array}$ & $\begin{array}{l}\text { Investigação da } \\
\text { cognição e } \\
\text { reaçőes } \\
\text { biométricas }\end{array}$ \\
\hline $\begin{array}{l}\text { Tipo de } \\
\text { processo de } \\
\text { resposta }\end{array}$ & $\begin{array}{l}\text { Especulativa, } \\
\text { exceto quando } \\
\text { usada para } \\
\text { acessar } \\
\text { protótipos }\end{array}$ & $\begin{array}{l}\text { Oentrevistado } \\
\text { deve tentar } \\
\text { ponderar sua } \\
\text { decisão através } \\
\text { da } \\
\text { introspecção, } \\
\text { em seguida, } \\
\text { mapear essas } \\
\text { ponderaçőes } \\
\text { na escala de } \\
\text { resposta }\end{array}$ & $\begin{array}{l}\text { Uma escolha } \\
\text { hipotética, do } \\
\text { mesmo modo } \\
\text { que uma } \\
\text { escolha de } \\
\text { compra mas } \\
\text { sem envolver } \\
\text { desembolso. }\end{array}$ & $\begin{array}{l}\text { Uma escolha } \\
\text { efetiva, com } \\
\text { clientes } \\
\text { utilizando } \\
\text { dinheiro e } \\
\text { portanto com } \\
\text { escolhas reais. }\end{array}$ & $\begin{array}{l}\text { Especulativa } \\
\text { com Respostas } \\
\text { de associação } \\
\text { livre } \\
\text { "brainstorm" } \\
\text { sobre o tema } \\
\text { investigado ou } \\
\text { focus groups. } \\
\text { Trabalho } \\
\text { posterior de } \\
\text { analise das } \\
\text { declaraçőese } \\
\text { as correlaçőes } \\
\text { com a cultura, } \\
\text { códigos, } \\
\text { signos } \\
\text { vigentes e seu } \\
\text { significado }\end{array}$ & $\begin{array}{l}\text { Tempo de } \\
\text { duração de } \\
\text { determinada } \\
\text { tarefa, a } \\
\text { exatidão de } \\
\text { seu } \\
\text { desempenho, } \\
\text { osrelatos } \\
\text { verbais, } \\
\text { associaçőese } \\
\text { as evidências } \\
\text { da } \\
\text { neurociência }\end{array}$ & $\begin{array}{l}\text { Dados } \\
\text { quantitativos. } \\
\text { Reaçőes } \\
\text { cerebrais( } \\
\text { neuroimagem) } \\
\text { acrescida de } \\
\text { mediçőes } \\
\text { biométricas como } \\
\text { reações visuais, } \\
\text { de pele, muscular } \\
\text { ou alteração } \\
\text { batimento } \\
\text { cardiaco) }\end{array}$ \\
\hline Uso típico & $\begin{array}{l}\text { No início para } \\
\text { ajudar design } \\
\text { de produto, } \\
\text { para testar } \\
\text { forma de } \\
\text { utilização. }\end{array}$ & $\begin{array}{l}\text { Na fase de } \\
\text { design, quando } \\
\text { a escolha é } \\
\text { importante }\end{array}$ & $\begin{array}{l}\text { Na fase de } \\
\text { design quando } \\
\text { a escolha é } \\
\text { importante. } \\
\text { Pode ser } \\
\text { utilizado como } \\
\text { ferramenta de } \\
\text { previsão. }\end{array}$ & $\begin{array}{l}\text { No fim do } \\
\text { processo de } \\
\text { previsão de } \\
\text { vendase } \\
\text { medição de } \\
\text { resposta para } \\
\text { outros } \\
\text { elementos de } \\
\text { marketing } \\
\text { como por } \\
\text { exemplo o } \\
\text { preço. }\end{array}$ & $\begin{array}{l}\text { Em açőes de } \\
\text { comunicação } \\
\text { bem como } \\
\text { avaliação de } \\
\text { significado da } \\
\text { marca }\end{array}$ & $\begin{array}{l}\text { No teste de } \\
\text { idéias, } \\
\text { reaçőes a } \\
\text { imagens, } \\
\text { símbolose } \\
\text { valorese } \\
\text { estímulos da } \\
\text { marca. }\end{array}$ & $\begin{array}{l}\text { Avaliar reaçőes } \\
\text { aos estímulos do } \\
\text { produto/serviço } \\
\text { marca nas } \\
\text { diversas fases do } \\
\text { desenvolvimento }\end{array}$ \\
\hline Custos e Riscos & $\begin{array}{l}\text { Baixo custo, } \\
\text { com risco } \\
\text { quando há má } \\
\text { utilização pelo } \\
\text { fornecedor. }\end{array}$ & $\begin{array}{l}\text { Custo } \\
\text { moderado e } \\
\text { algum risco de } \\
\text { informara } \\
\text { concorrência. }\end{array}$ & $\begin{array}{l}\text { Custo } \\
\text { moderado, } \\
\text { mais alto } \\
\text { quando na } \\
\text { utilizaça̋o de } \\
\text { protótipos ao } \\
\text { invés de } \\
\text { descriçőes ou } \\
\text { conceitos. } \\
\text { Algum risco de } \\
\text { alerta aos } \\
\text { concorrentes. }\end{array}$ & $\begin{array}{l}\text { Alto custo e } \\
\text { alto risco de } \\
\text { informar } \\
\text { concorrência. } \\
\text { Além do risco } \\
\text { do produto ser } \\
\text { copiado antes } \\
\text { do lançamento. }\end{array}$ & $\begin{array}{l}\text { Baixo, com } \\
\text { risco pois } \\
\text { depende da } \\
\text { analise e } \\
\text { interpretação } \\
\text { do } \\
\text { entrevistador. }\end{array}$ & $\begin{array}{l}\text { Custo } \\
\text { moderado a } \\
\text { Alto. Risco de } \\
\text { interpretaçăo }\end{array}$ & $\begin{array}{l}\text { Alto custo e alto } \\
\text { risco de } \\
\text { interpretação e } \\
\text { erro. }\end{array}$ \\
\hline $\begin{array}{l}\text { Habilidade } \\
\text { técnica } \\
\text { necessária }\end{array}$ & $\begin{array}{l}\text { Habilidades } \\
\text { para } \\
\text { moderação } \\
\text { quando do } \\
\text { grupo e } \\
\text { habilidades } \\
\text { etnográfica } \\
\text { para os } \\
\text { observadorese } \\
\text { analistas. }\end{array}$ & $\begin{array}{l}\text { Design de } \\
\text { questionário e } \\
\text { análise } \\
\text { estatística }\end{array}$ & $\begin{array}{l}\text { Design } \\
\text { experimental e } \\
\text { análise } \\
\text { estatística, } \\
\text { incluindo } \\
\text { modelagem. }\end{array}$ & $\begin{array}{l}\text { Altamente } \\
\text { especializado } \\
\text { em teste de } \\
\text { mercado ( } \\
\text { observação, } \\
\text { coleta e análise } \\
\text { de dados) e } \\
\text { ferramentas de } \\
\text { previsão. } \\
\text { Altamente } \\
\text { especializado. }\end{array}$ & $\begin{array}{l}\text { Habilidade } \\
\text { similar a do } \\
\text { focus groups } \\
\text { acrescida de } \\
\text { habilidade de } \\
\text { analise dos } \\
\text { códigose } \\
\text { valores } \\
\text { culturais } \\
\text { vigentes }\end{array}$ & $\begin{array}{l}\text { Altamente } \\
\text { especializado } \\
\text { em técnicas } \\
\text { cognitivas } \\
\text { como a } \\
\text { psicologiae } \\
\text { neurociência. }\end{array}$ & $\begin{array}{l}\text { Altamente } \\
\text { especializado: } \\
\text { neurociência e } \\
\text { psicologia } \\
\text { cognitiva e } \\
\text { estatística para } \\
\text { combinação de } \\
\text { dadosentre } \\
\text { diferentes } \\
\text { técnicas. }\end{array}$ \\
\hline $\begin{array}{c}\text { Fase de } \\
\text { Marketing }\end{array}$ & $\begin{array}{l}\text { Para } \\
\text { entendimento } \\
\text { na elaboração } \\
\text { de } \\
\text { conceito/produ } \\
\text { to } \\
\text { /comunicação. }\end{array}$ & $\begin{array}{l}\text { Escolha de } \\
\text { opçőes entre } \\
\text { conceito/produ } \\
\text { to/comunicaçă } \\
\text { o. }\end{array}$ & $\begin{array}{l}\text { Escolha entre } \\
\text { opção final de } \\
\text { produto. Fase } \\
\text { pré- } \\
\text { lançamento. }\end{array}$ & $\begin{array}{l}\text { Pós } \\
\text { lançamento de } \\
\text { produto no } \\
\text { mercado do } \\
\text { teste e pré } \\
\text { lançamento } \\
\text { para expansão } \\
\text { para outros } \\
\text { mercados. }\end{array}$ & $\begin{array}{l}\text { Entendimento } \\
\text { de materiais } \\
\text { de estimulo da } \\
\text { marca. }\end{array}$ & $\begin{array}{l}\text { Teste de } \\
\text { produto, } \\
\text { conceito e } \\
\text { seus diversos } \\
\text { materiais de } \\
\text { estímulo }\end{array}$ & $\begin{array}{l}\text { Tpdas do início à } \\
\text { pós avaliação }\end{array}$ \\
\hline $\begin{array}{l}\text { Fase do } \\
\text { Processo de } \\
\text { Decisão }\end{array}$ & $\begin{array}{l}\text { Inpute } \\
\text { experiencia }\end{array}$ & $\begin{array}{l}\text { Inpute } \\
\text { experiencia }\end{array}$ & Input e Output & Output & $\begin{array}{l}\text { Inpute } \\
\text { Processo } \\
\text { decisório }\end{array}$ & $\begin{array}{l}\text { Inpute } \\
\text { Processo } \\
\text { decisório }\end{array}$ & $\begin{array}{l}\text { Input e Processo } \\
\text { decisório }\end{array}$ \\
\hline
\end{tabular}


Portanto, conclui-se que para os processos decisórios, os estudos explorados como a semiótica e ciências cognitivas complementam os métodos de investigação do comportamento conhecidos principalmente na fase do processo decisório. O neuromarketing, conclui-se ao final, pode oferecer ganhos no entendimento das reações aos estímulos das marcas. Até o momento, é um acordo comum entre vários estudiosos que este entendimento se dá na medição das reações dos mesmos em distintas áreas do cérebro, buscando a identificação e a correlação com o fato gerador. Por meio de complementação com biometria e questionários, depreende-se que existe a possibilidade de melhoria de seu entendimento buscando qualificar o sentido do estímulo tanto da compreensão de sua origem quanto de qualificar se o mesmo é positivo ou negativo, ou de medir situações mais próximas às vivências do dia a dia. No entanto, qualquer conclusão obtida em sua aplicação em marketing ainda tem que ser analisada com cuidado, entendendo que o cérebro é muito complexo e que os tempos de reação e a localização dependem da qualidade do estímulo, seu isolamento, sua duração, a forma como foi capturada, a ambientação, a forma como foi correlacionada com outros dados, enfim, uma gama complexa de itens que podem interferir na leitura dos dados e suas conclusões. A busca por protocolos e mais estudos é encorajada pelas pessoas envolvidas nos estudos da neurociencia e a velocidade de seu desenvolvimento tem sido grande. No entanto, é escassa a produção acadêmica que elucida o campo em um sentido mais amplo de conceitos, métodos de coleta e análise, disponível na atualidade. Muitos estudos ainda são necessários e estão cada vez mais sendo explorados nas áreas acadêmica e de estudos de mercado.

Como diz Castells (2009) o poder é construído, como toda a realidade, nas redes neuronais do nosso cérebro. A energia é gerada em moinhos de vento da mente. Como é um processo individual, complexo e combinatório, acredita-se na necessidade de uma contínua exploração, utilizando-se uma população plural de especialistas, com um trabalho coletivo de trocas de conhecimento, em rede, que seja capaz de gerar maior inter-relação de especialidades e conexões sobre o tema, obtendo-se assim maiores esclarecimentos sobre o que rege os comportamentos e suas expressões, transparentes ou não, que possam aclarar as motivações dos consumidores para suas escolhas. 


\section{MÉTODO DA PESQUISA DE CAMPO}

A revisão bibliográfica, compreendida na primeira parte da dissertação, possibilitou obter maior conhecimento sobre uma área onde os recursos são escassos: análise do comportamento do consumidor pelos dados não declarados. Assim, essa etapa propiciou um arcabouço histórico sobre o assunto - comportamento do consumidor em sua forma não declarada - e ajudou a definir com maior clareza o objetivo do estudo em questão. Ainda nessa etapa de pesquisa realizou-se uma análise de novos campos de exploração do comportamento não declarados por estímulos de marketing com utilização da semiótica, estudos da ciência cognitiva e finalmente o neuromarketing, no intuito de compreender suas aplicações nas diversas fases do marketing sob diversos pontos de vista.

Este capítulo tem o propósito de contribuir para a ampliação da compreensão dos aspectos de pesquisa empírica, tendo como foco explorar possibilidades de conhecimento do comportamento não declarado em pauta com o neuromarketing, visando permitir um volume maior de informação e maior direcionamento para o tema, bem como a reprodutividade do estudo. Com isso em mente, são feitas algumas considerações sobre as áreas de estudos e descreve-se o tipo de pesquisa. Além disso, explicita-se o método de coleta de dados, a seleção dos entrevistados que contribuíram com seus conhecimentos, o procedimento analítico e conclusões da pesquisa.

\subsection{Introdução}

A pesquisa de campo apresentada é de natureza exploratória, qualitativa, com variáveis descritivas e objetivo de explorar o campo da neurociência e sua possível contribuição ao estudo de comportamento do consumidor em marketing, com coleta de dados de campo realizada por meio de entrevista em profundidade. Serão abordados dois públicos distintos, os acadêmicos, que de alguma forma estudam neurociência e sua aplicação na área do comportamento humano e o público composto por indivíduos não acadêmicos, ou aqueles que utilizam de forma instrumental os estudos da neurociência, ao exercerem suas profissões na investigação do comportamento do consumidor. 
O propósito da pesquisa é cumprir o objetivo proposto na dissertação para o problema em questão por meio da aplicação de método científico. Tais métodos foram criados para aumentar as chances de que a informação obtida seja significativa, precisa e não apresente vieses. Não há garantias sobre a obtenção de resultados significativos com a utilização de método, mas sim maior probabilidade de sucesso seguindo uma metodologia previamente testada. Esta é a base do conhecimento científico. (SELLTIZ et al, 1960).

Lakatos e Marconi (1991) definem método científico como o conjunto de atividades sistemáticas e racionais que permitem alcançar o objetivo, ou seja, responder a pergunta da pesquisa com conhecimentos verdadeiros e válidos, de forma a traçar um caminho que possa ser seguido por cientistas, minimizando erros e aumentando a probabilidade de acertos que auxiliem nas conclusões do estudo. A pesquisa, para os autores, requer um processo formal, que requer tratamento científico quando o que se busca é conhecer a realidade, mesmo que parcialmente. $\mathrm{O}$ projeto de pesquisa envolve seis passos distintos:

- seleção do problema a ser investigado;

- definição e delimitação do problema;

- levantamento de hipóteses;

- coleta, sistematização e classificação dos dados;

- análise e interpretação dos resultados;

- relatório dos resultados da pesquisa.

Nesta dissertação, a investigação com variado e seleto grupo de investigados buscará responder ao seguinte objetivo específico:

- Avaliar se o neuromarketing pode ser uma nova área de colaboração ao entendimento do consumidor

- Além do objetivo específico, buscou-se também avaliar:

○ Quais seriam as informações não declaradas do consumidor que podem ser capturadas do cérebro para corroborar no processo do entendimento de seu comportamento?

- Quais as técnicas utilizadas e recomendadas para isso;

○ Quais seriam as questões de marketing investigadas;

- Contribuições e dificuldades 
○ Possibilidade de futuros desenvolvimentos;

Respondidas as questões acima mencionadas acredita-se que houve uma complementação da literatura revisada fornecendo aspectos mais específicos do neuromarketing ao estudo do comportamento do consumidor para o problema de pesquisa proposto na dissertação. Fica claro também as considerações em relação a possíveis diferenças entre a teoria e aplicações no campo acadêmico e a prática utilizada em empresa de pesquisa de mercado, bem como suas similaridades.

\subsection{Tipos de Pesquisa}

Existem diferentes maneiras de fazer pesquisa em ciências sociais, cada uma com suas vantagens e desvantagens, entre elas: estudo de caso, levantamentos, pesquisas históricas, experimentos (YIN, 2005). Para definição de qual estratégia usar, o autor sugere três tipos de fatores: qual o tipo em questão de pesquisa a ser investigado; o controle que o investigador tem sobre o comportamento a ser investigado; foco em fenômenos contemporâneos em oposição a fenômenos históricos. Diante da temporalidade do fenômeno em questão, como se trata de um assunto contemporâneo, a recomendação é a utilização de levantamento, estudo de caso ou experimento. Outro fator a ser analisado é o controle que se tem das informações, caso o pesquisador tenha controle dos dados, a recomendação é a utilização do experimento, caso contrário, outras quatro alternativas metodológicas são passíveis de utilização.

Cada estudo tem seu objetivo específico e este é o determinante do tipo de estudo a ser seguido. Os objetivos de pesquisa podem ser agrupados, dependendo da cristalização de seu problema, em três tipos: os estudos formuladores ou exploratórios, onde a principal acentuação refere-se à descoberta de ideias e intuições; os estudos descritivos, onde o que se busca é o detalhamento de um determinado fenômeno e sua frequência; e, finalmente, os estudos de objetivo causal, onde se busca claramente entender as hipóteses que influenciaram o evento a ponto de determinar seu resultado, sua relação causa-efeito (SELLTIZ et al, 1960). Cada tipo é mais indicado para um determinado fenômeno, mas para o autor, o que se encontra na prática é que nem sempre são nitidamente separáveis. Uma pesquisa pode conter elementos de uma ou mais funções descritas como características de diferentes tipos de 
estudo. Portanto, embora não sejam bem definidas as distinções entre diferentes tipos de estudo, de um modo geral, é possível fazer tais distinções para poder discutir o melhor e mais adequado planejamento para a pesquisa.

Este estudo adota uma abordagem exploratória, uma vez que seu objetivo é aumentar o conhecimento sobre um tema novo na literatura e, portanto, este caráter inovador sugere a necessidade de familiarização com o tema, buscando um maior conhecimento de seu procedimento e seus prováveis resultados, sem o intuito de ser conclusivo e sim contribuir com uma melhora dos procedimentos, seus prováveis resultados, limitações e erros para serem explorados em estudos no futuro.

A classificação da pesquisa, de acordo com Mattar (2011) pode ser feita quanto:

(a) à natureza das variáveis pesquisadas (qualitativa_e quantitativa);

(b) à natureza do relacionamento entre as variáveis estudadas (descritiva e causal);

(c) ao objetivo e ao grau em que o problema de pesquisa está cristalizado (exploratória e conclusiva);

(d) à forma utilizada para a coleta de dados primários (pesquisa por comunicação ou observação);

(e) ao escopo da pesquisa em termos de amplitude e profundidade (estudo de caso, de campo ou levantamento amostral);

(f) à dimensão da pesquisa no tempo (ocasional ou evolutiva);

(g) à possibilidade de controle sobre as variáveis em estudo (experimental de laboratório, experimental de campo ou pesquisa ex post facto);

(h) ao ambiente de pesquisa (pesquisa de campo, de laboratório e pesquisa por simulação).

Enquanto a pesquisa qualitativa identifica a presença ou ausência de algo, a quantitativa mede o grau em que algo está presente. Ambas podem ser utilizadas em uma mesma pesquisa e combinadas em um mesmo instrumento. A diferença entre descritiva e causal se dá quanto a seus objetivos. A descritiva busca saber quem, o quê, quanto, quando e onde; a causal quer saber por quê. O objetivo e o grau em que o problema em questão está cristalizado determinam a diferença entre uma pesquisa exploratória, onde pouco ou nada está estruturado, e a pesquisa conclusiva, onde há estruturação dos procedimentos, hipóteses definidas e objetivos claros. A forma mais tradicional de obtenção dos dados é através da comunicação 
com o detentor dos dados, mas também pode se dar através de algum instrumento como questionário ou até mesmo pela observação dos comportamentos. Outro ponto importante para determinar o escopo da pesquisa é a amplitude e profundidade - sua representatividade em relação à população pesquisada e o grau de ocorrência. Pode realizar-se uma única vez, ocasionalmente (ad hoc) ou evolutivamente. Ainda pode variar de acordo com o grau de controle das variáveis e quanto ao ambiente de pesquisa, se este é real ou artificial ou simulado. $\mathrm{O}$ autor ainda descreve a multiplicidade de abordagens da pesquisa quanto as suas classificações de acordo com seus principais autores, cada um com conceito complexo que não pode ser descrito de maneira única. O pesquisador optará por um ou uma combinação dos seguintes métodos ou tipos de pesquisa: pesquisa exploratória, conclusiva, descritiva ou simplesmente pesquisa descritiva e pesquisa conclusiva explicativa.

Para Selltiz et al (1960) o problema do estudo é provavelmente o passo mais importante a ser considerado na escolha da pesquisa. Dado que o objetivo deste trabalho é realizar um entendimento em profundidade, escolheu-se uma pesquisa qualitativa. Definido o problema de pesquisa - no caso da dissertação seria identificar quais informações não declaradas do consumidor podem ser capturadas do cérebro para um maior entendimento de seu comportamento - a escolha do tipo de pesquisa é ainda de caráter exploratório, onde o que se busca é agregar diversos pontos de vista sobre o tema em estudo, buscando encontrar esclarecimento por meio de consenso e próximos passos pelas discordâncias e, portanto, necessidade de investigação futura.

Uma vez definidos o tipo e as características da pesquisa, cabe explicar o método de coleta de dados.

\subsection{Métodos e técnicas de coleta de dados}

Para Vieira (2002) a pesquisa descritiva objetiva conhecer e interpretar a realidade sem nela interferir para modificá-la (CHURCHILL, 1996). Muitas das pesquisas de marketing realizadas são de caráter conclusivo descritivo. Pode-se dizer que ela está interessada em descobrir e observar fenômenos, procurando descrevê-los, classificá-los e interpretá-los. Além disso, pode se interessar pelas relações entre variáveis e, desta forma, aproximar-se das 
pesquisas experimentais. O planejamento da coleta de dados vai depender do tipo de pesquisa e dos métodos e técnicas a serem utilizados e podem compreender as seguintes definições: o perfil dos entrevistadores, o número de entrevistadores, o prazo para realização do campo, a remuneração do entrevistador, o material e a forma de treinamento, procedimento de coleta a ser seguido e verificação das entrevistas realizadas.

Para Mattar (2011), em função do tipo de pesquisa escolhido e da fonte de dados, o pesquisador deverá a seguir determinar quais métodos e técnicas que a coleta de dados irá utilizar. Poderá optar por um, ou uma combinação das seguintes opções:

- levantamento bibliográfico;

- levantamentos documentais;

- estatísticas publicadas;

- entrevistas com entendidos;

- entrevistas focalizadas de grupo (pesquisa de motivação);

- observação sistemática;

- observação assistemática;

- entrevistas pessoais;

- entrevistas pelo telefone;

- questionários distribuídos e recolhidos pelo correio, fax, internet ou pessoalmente;

- levantamento de campo;

- estudos de campo;

- estudos de laboratório;

- estudos de casos.

Existem dois meios básicos de obtenção de dados: a comunicação e a observação. O método da comunicação consiste no questionamento, verbal ou escrito, dos respondentes para a obtenção de dados desejados, que será fornecido por declaração dos próprios. A estruturação, segundo Mattar (2011), pode ser disfarçada ou não, e aplicado em entrevista pessoal, individual ou em grupos ou via telefone, ou pode ser respondido em questionários autopreenchidos. A escolha do método de coleta de dados implica em um número de decisões suplementares como saber se as pessoas conseguem autoadministrar o instrumento de coleta ou se há necessidade de um entrevistador; se será individual ou em grupo, pessoal ou por outro meio indireto, com questionário aplicado ou roteiro. 
As questões abertas, ou as referentes à aplicação de um roteiro, de acordo com Malhorta (2011) como detalhado no Quadro 8 são úteis para identificar as motivações, crenças e atitudes fundamentais, pois permitem aos entrevistados a expressão das opiniões gerais, se existe influência associada com as respostas limitadas às alternativas predefinidas. Portanto, são úteis na pesquisa exploratória, no entanto, apresentam algumas desvantagens como erro de registro, a codificação de dados e a maior complexidade da análise, além de aumentar a dependência no entrevistador e dar peso extra aos entrevistados mais comunicativos ou articulados. Esse tipo de processo é também mais demorado e custoso.

Quadro 8 - Modelo de tipologia em entrevista

\begin{tabular}{|c|c|c|c|c|c|}
\hline Pesquisa & Questões & Entrevista & Modelo & Abordagem & Respostas \\
\hline \multirow{2}{*}{ Qualitativa } & $\begin{array}{c}\text { Não- } \\
\text { estruturadas }\end{array}$ & Aberta & $\begin{array}{l}\text { Questão } \\
\text { Central }\end{array}$ & \multirow{2}{*}{$\begin{array}{c}\text { Em } \\
\text { Profundidade }\end{array}$} & \multirow{2}{*}{ Indeterminadas } \\
\hline & $\begin{array}{c}\text { Semi- } \\
\text { estruturadas }\end{array}$ & $\begin{array}{l}\text { Semi- } \\
\text { aberta }\end{array}$ & Roteiro & & \\
\hline Quantitativa & Estruturadas & Fechada & Questionário & Linear & Previstas \\
\hline
\end{tabular}

FONTE: ADAPTADO DE MALHORTA, 2011, p 122.

As entrevistas estruturadas são elaboradas mediante questionário, as perguntas são previamente formuladas e se tem o cuidado de não fugir a elas. O principal motivo deste zelo é a possibilidade de comparação com o mesmo conjunto de perguntas e que as diferenças devem refletir as diferenças entre os respondentes e não diferença nas perguntas (LAKATOS; MARCONI, 1991). A técnica de entrevistas abertas atende principalmente a finalidades exploratórias, é bastante utilizada para o detalhamento de questões e formulação mais precisas dos conceitos relacionados. Em relação a sua estruturação, o entrevistador introduz o tema e o entrevistado tem liberdade para discorrer sobre o tema sugerido sendo guiado apenas por grandes tópicos. É uma forma de poder explorar mais amplamente um assunto, onde as perguntas são respondidas dentro de uma conversação informal. Para não interromper o fluxo de ideias do respondente, a interferência do entrevistador deve ser a mínima possível e este deve assumir uma postura de ouvinte, evitando interromper a fala do informante. A entrevista aberta é utilizada quando o pesquisador deseja obter o maior número possível de informações sobre determinado tema, segundo a visão do entrevistado, e também para obter um maior detalhamento do assunto em questão. Geralmente é utilizada na descrição de casos individuais, na compreensão de especificidades culturais para determinados grupos e na comparabilidade de diversos casos. A entrevista semiestruturada combina perguntas abertas e fechadas, onde o informante tem a possibilidade de discorrer sobre o tema proposto. $\mathrm{O}$ 
pesquisador deve seguir um conjunto de questões previamente definidas, mas ele o faz em um contexto muito semelhante ao de uma conversa informal. O entrevistador deve ficar atento para dirigir, no momento que achar oportuno, a discussão para o assunto que o interessa, fazendo perguntas adicionais para elucidar questões que não ficaram claras ou ajudar a recompor o contexto da entrevista, caso o informante tenha se afastado do tema. Esse tipo de entrevista é muito utilizado quando se deseja delimitar o volume das informações, obtendo assim um direcionamento maior para o tema, intervindo a fim de que os objetivos sejam alcançados. A principal vantagem da entrevista aberta e também da semiestruturada é que ambas as técnicas quase sempre produzem uma melhor amostra da população de interesse, no caso desta dissertação - estudiosos do neuromarketing ou instrumentistas que utilizam o tema como produto.

Nesta pesquisa foi utilizado o segundo modelo, a pesquisa qualitativa, semiestruturada, semiaberta, com utilização de roteiro para abordagem em profundidade, com obtenção de respostas indeterminadas que necessitam de interpretação a posteriori.

Ao contrário dos questionários enviados por correio que têm índice de devolução muito baixo, a entrevista tem um índice de respostas bem mais abrangente, uma vez que é mais comum as pessoas aceitarem falar sobre determinados assuntos (SELLTIZ et al, 1960). Outra vantagem diz respeito à dificuldade que muitas pessoas têm de responder por escrito. Além do mais, esses dois tipos de entrevista possibilitam a correção de enganos dos informantes, enganos que muitas vezes não poderão ser corrigidos no caso da utilização do questionário escrito. As técnicas de entrevista aberta e semiestruturada também têm como vantagem a sua elasticidade quanto à duração, permitindo uma cobertura mais profunda sobre determinados assuntos. Além disso, a interação entre o entrevistador e o entrevistado favorece as respostas espontâneas, permitindo maior abertura e proximidade, o que facilita a abordagem de assuntos mais complexos e delicados. Quanto às desvantagens, estas dizem muito mais respeito às limitações do próprio entrevistador, como escassez de recursos financeiros e de tempo. Por parte do entrevistado existe a insegurança em relação ao seu anonimato e, por essa causa, muitas vezes ocorre a retenção de informações importantes. Essas questões são, ainda assim, melhor apreendidas pela entrevista aberta e semiestruturada. Vale lembrar que a qualidade das entrevistas depende muito do planejamento feito pelo entrevistador; este deve transmitir, acima de tudo, confiança ao informante. 
Mattar (2011) em sua comparação entre características dos métodos de comunicação, quanto à forma de aplicação, detalha as principais características entre entrevista pessoal, por telefone e questionário autopreenchido, sendo que as mesmas apresentam vantagens, como: alta versatilidade; alto controle amostral; quantidade de dados; alto índice de resposta; diferentes níveis de respondentes; grande averiguação de sinceridade das respostas e baixo tamanho de amostra, razões da escolha da entrevista pessoal como método de coleta de dados para este estudo, conforme descrito no Quadro 9:

\begin{tabular}{|c|c|c|c|}
\hline \multicolumn{4}{|c|}{ Quadro 9 - Tipos de pesquisa } \\
\hline Característica & $\begin{array}{l}\text { Entrevista } \\
\text { pessoal }\end{array}$ & Entrevista por telefone & $\begin{array}{l}\text { Questionário } \\
\text { autopreenchido }\end{array}$ \\
\hline Versatilidade & alta & média & baixa \\
\hline Custo & alto & médio & baixo \\
\hline Tempo para aplicação & alto & baixo & médio \\
\hline Controle amostral & alto & médio & baixo \\
\hline Quantidade de dados & alta & média & média \\
\hline Qualidade dos dados & & (vide Quadro 5.13) & \\
\hline Garantia de anonimato & baixa & baixa & média \\
\hline Habilidade exigida para aplicação & alta & alta & baixa \\
\hline Uniformidade da mensuração & baixa & média & alta \\
\hline Índice de resposta & alto & alto & baixo \\
\hline $\begin{array}{l}\text { Nível educacional exigido dos } \\
\text { respondentes }\end{array}$ & baixo & baixo & alto \\
\hline $\begin{array}{l}\text { Possibilidade de verificação da } \\
\text { sinceridade das respostas }\end{array}$ & alta & baixa & baixa \\
\hline Tamanho da amostra & pequena & grande & grande \\
\hline
\end{tabular}

FONTE: MATTAR, 2011, p. 186.

Não se busca generalizar ou provar algo com entrevistas em profundidade, mas seu caráter subjetivo exige adequada formulação dos procedimentos metodológicos e confiança nos resultados obtidos. A questão é relevante, pois não basta ouvir fontes e fazer um relato para considerar realizada uma pesquisa válida e confiável. A confiabilidade diz respeito ao rigor metodológico que garante que, repetidos os procedimentos, os resultados serão os mesmos. Isto exige tanto a confirmação das informações obtidas na pesquisa de campo quanto a articulação adequada destas informações na descrição, a coerência da análise com o quadro de reflexão proposto e conclusões consistentes com os passos anteriores. A obtenção de confiabilidade é baseada na descrição pormenorizada dos procedimentos de operacionalização das entrevistas e uso fundamentado e consistente das respostas obtidas. Validade e confiabilidade no uso da técnica de entrevistas em profundidade dizem respeito, 
particularmente, a três questões: seleção de informantes capazes de responder à questão da pesquisa, ou seja, pessoas que são relacionadas academicamente ou em prática ao tema neurociência e comportamento; uso de procedimentos que garantam a obtenção de respostas confiáveis, no caso a utilização de questionários aplicados por pessoa com conhecimento prévio sobre o tema; descrição dos resultados que articule consistentemente as informações obtidas com o conhecimento teórico disponível, obtida pela análise de conteúdo na dissertação em foco.

Malhorta (2011) menciona a importância de definir o assunto na aplicação do questionário de entrevista, utilizar palavras simples, que não sejam ambíguas, sem vieses, organizando em uma ordem adequada, com questões de abertura, estabelecendo uma relação entre entrevistador e entrevistado, evitando questões que influenciem as respostas subsequentes. Recomenda ir do geral ao específico, o que é chamado abordagem tipo funil, pois começa com questões mais amplas e gerais e afunila para as mais específicas. As características físicas ou o formato podem influenciar, portanto, a recomendação é dividir o questionário ou roteiro em seções com áreas de tópicos separadas. O pré-teste é recomendado. Todos os aspectos do questionário, incluindo o conteúdo das questões, o texto, a sequência, a dificuldade, devem ser testados, pois deve ser feito baseado no perfil dos entrevistados.

Para Lakatos e Marconi (1991) a etapa de coleta de dados é a materialização das respostas ao problema de pesquisa, sendo diretamente determinante dos processos pelos quais os dados podem ser sistematizados e classificados, e da qualidade com a qual as análises podem ser feitas.

O método e o instrumento de coleta de dados foram entrevistas pessoais ou por telefone. Assim, a coleta foi realizada por comunicação, com utilização de roteiro para aplicação de entrevista em profundidade, realizada em uma só vez, de forma ocasional, em um contexto semelhante ao de uma conversa informal. Estas foram gravadas e transcritas em forma integral.

Na etapa empírica desta dissertação a coleta de dados foi realizada com a utilização da técnica de entrevistas em profundidade, o qual ocorreu entre julho e setembro de 2011. Os procedimentos metodológicos adotados foram: 
- organização de um roteiro que permitisse ao entrevistador seguir uma sequência lógica e ordenada que facilite o raciocínio, minimize o desperdício de tempo e também diminua enganos na condução da entrevista;

- obtenção de indicação de pessoas ligadas à área de estudo ou práticas de investigação do comportamento nas diferentes especialidades como psicologia, neurociência e comunicação;

- organização de entrevistas com duração entre 45 a 60 minutos com os respondentes, por meio de telefone ou Skype, no idioma de preferência do respondente, podendo este ser português ou inglês.

Foi realizado um pré-teste do roteiro para que ajustes fossem realizados na compreensão e sequência dos questionamentos. Para Selltiz et al (1960) o pré-teste visa minimizar dificuldades que poderiam ser encontradas, permitindo que a obtenção de informações necessárias à etapa de campo ocorra de acordo com o previsto.

Anteriormente à entrevista e após o levantamento dos potenciais entrevistados, houve a demarcação de data, horário e forma de comunicação mais conveniente ao entrevistado e a informação do tempo necessário para a conversa. As entrevistas foram realizadas por telefone ou por internet, nesse caso via skype, por voz ou vídeo, e foram gravadas após permissão dos entrevistados, o que ocorreu em 100\% da amostra. O instrumento foi particularmente útil para os entrevistados geograficamente distantes, ou para aqueles de difícil acesso por problemas de agenda. No momento da entrevista foi explicado ao respondente o tema foco, bem como a liberdade de resposta ou não a certas perguntas. Houve o esclarecimento de que o objetivo do trabalho não era de um julgamento e sim de somatória da experiência do entrevistado na questão em estudo e obtenção de sua contribuição ao tema explorado. Caso o entrevistado demonstrasse interesse houve a disponibilização da cópia de suas declarações, bem como da publicação resultante da entrevista.

No ato da entrevista, uma série de cuidados foi tomada no intuito de garantir a obtenção de informações e também a neutralidade do entrevistador. Houve a preparação por parte do entrevistador acerca do conteúdo básico sobre o tema e também cuidado na escolha e preparação da melhor forma de coleta da entrevista, evitando o desperdício da colaboração por questões técnicas ou despreparo. 
Para alcançar o objetivo deste estudo, o roteiro foi dividido em vários tópicos. No início da entrevista houve uma declaração sobre dados básicos do entrevistado como sua formação, desenvolvimento de carreira e atuação profissional atual, informações úteis para contextualizar as informações e para relacionar os entrevistados no relatório. Buscou-se estabelecer ambiente de naturalidade, confiança mútua e interesse desde o início. Houve, ao início, uma introdução para relembrar o objetivo do trabalho e da participação, bem como sua duração e procedimento de gravação da entrevista. Após essa fase houve uma introdução geral e construção do histórico do trabalho do respondente. O que se buscou foi uma aproximação de sua atuação ao tema em questão, qual seja, seu envolvimento com a neurociência e os estudos sobre comportamento. A partir deste ponto o que se iniciou foi uma busca exploratória dos conhecimentos específicos da neurociência, suas técnicas, a aplicação em marketing, a definição do neuromarketing, as técnicas conhecidas e utilizadas, opiniões, suas vantagens, bloqueios e problemas enfrentados, o futuro e também as fontes de informação sobre o tema.

A condução pelo roteiro foi realizada sem interrupções, mesmo quando o entrevistado não soube responder o assunto. Houve repetição da pergunta em outros termos sempre quando a primeira tentativa não foi suficientemente compreendida. Ao final, após exploração de todo o conteúdo do roteiro, encerrou-se perguntando se haveria alguma questão a complementar, o que seguiu com um agradecimento.

O instrumento utilizado para a coleta foi entrevista gravada com a devida permissão do entrevistado, o que possibilitou o registro literal e integral das declarações. As transcrições ocorreram na primeira quinzena de setembro, logo após o término das entrevistas. No estudo proposto as entrevistas foram conduzidas pela dificuldade geográfica da maioria dos participantes, via contato telefônico ou meio eletrônico (skype), sendo que em somente um caso, foi realizado por email, na forma de questionário aberto. Todas as entrevistas foram gravadas e transcritas, com exceção da última mencionada.

Em um detalhamento maior do roteiro utilizado os seguintes dados foram perguntados em uma sequência lógica:

1) Nome, função, local de trabalho, formação;

2) Entendimento do envolvimento com pesquisa de comportamento; os métodos utilizados em sua experiência; 
3) Conhecimento de neurociência; seu conhecimento de sua aplicação no marketing (neuromarketing) e a forma de obtenção do conhecimento;

4) Obtenção da definição de neuromarketing em seu ponto de vista; seus tipos de aplicação da investigação utilizados no neuromarketing; em quais estudos podem ser utilizados; em quais possibilidades utilizaria;

5) Descrição das possíveis contribuições para estudo do comportamento; as barreiras e dificuldades obtidas bem como as vantagens e desvantagens;

6) Existência de preocupações e a questão da ética;

7) Exploração de outros métodos que podem ser combinados para enriquecimento do conhecimento e a diversidade de áreas do saber;

8) O que imagina do futuro da área e próximos passos e quais as necessidades ainda não atendidas;

9) Entendimento da forma como se atualiza sobre o tema, bem como as fontes de informação;

10) Por último, a adição de comentário extra.

Além do instrumento de coleta de dados e do instrumento de comunicação, há outros procedimentos metodológicos da investigação que precisam ser definidos durante o planejamento do estudo e também durante a execução do trabalho de campo, tais como: quantidade de pessoas entrevistadas, bem como quais serão entrevistadas e a relação entrevistador-entrevistado.

\subsection{Seleção das fontes dos dados}

Mattar (2011) descreve que as fontes de dados podem provir dos próprios pesquisados por meio de observação ou declaração, outras fontes que tenham informações dos entrevistados, de situações similares às que se quer obter informações, ou ainda de dados já disponíveis, coletados previamente para outra finalidade.

Como no presente estudo se visa buscar fontes em pessoas que estudam ou utilizam a neurociência aplicada ao marketing, em sua busca por entendimento do consumidor, o universo pesquisado naturalmente é formado por pesquisadores, em sua forma acadêmica, ou seja, professores doutores das universidades brasileiras ou estabelecidas no exterior, onde a 
neurociência seja aplicada para captura do comportamento. Há ainda outro grupo formado por instrumentistas - pessoas que utilizam o neuromarketing atualmente como produto comercial de suas empresas, sejam elas brasileiras ou com sede no exterior. Ambos os grupos de entrevistados apresentam experiência e vivência anterior e atual sobre o tema.

Segundo Malhotra (2010), a amostragem não probabilística não utiliza seleção aleatória, ou seja, confia no julgamento pessoal do pesquisador para decidir conscientemente quais elementos devem ser incluídos na amostra. Dentre as técnicas de amostragem não probabilística encontram-se a amostragem por conveniência, na qual os elementos são escolhidos convenientemente pelo entrevistador. A amostragem por conveniência tem a vantagem de ser barata e rápida, no entanto, possui sérias limitações e, uma das principais é o fato de a amostra resultante não ser representativa para qualquer tipo definível de populaçãoalvo. Esse processo de amostragem sofre de viés de seleção, as pessoas que dele participam podem ter características sistematicamente diferentes daquelas que definem a população-alvo. Em virtude dessas limitações, não é teoricamente significativo generalizar para qualquer população os resultados advindos de uma amostra por conveniência. No entanto, mesmo com as limitações apontadas, estas são úteis para pesquisa exploratória, cujo objetivo é gerar ideias, adquirir novas compreensões e desenvolver hipóteses, razão pela qual a amostragem foi escolhida para o estudo em questão.

Neste estudo, agruparam-se 13 entrevistados apresentados em dois perfis diferenciados: $\mathrm{O}$ primeiro grupo é composto por aqueles que estão ligados no momento a uma universidade, portanto utilizam a neurociência como instrumento de estudo e pesquisa acadêmica. Nesse primeiro grupo encontramos professores atuais de várias universidades brasileiras e também estrangeiras, mais precisamente: as americanas Universidade de Harvard (www.harvard.edu/) e MIT (Massachussets Institute of Technology -web. mit.edu/), as brasileiras Universidade de São Paulo, mais precisamente professores doutores do Instituto de Ciências Biomédicas (www3.icb.usp.br/corpoeditorial/) e a italiana Universidade Sapienza de Roma (www.uniroma1.it/).

Participam do segundo grupo indivíduos, com formação acadêmica ou não, que no momento utilizam a neurociência e sua aplicação como instrumentistas, isto é, como ferramenta para investigar consumidores e oferecerem serviços remunerados como empresas de pesquisa de mercado. As empresas presentes são as americanas One to One e MSW; a inglesa 
NeuroSense, a multinacional Milward Brown e as brasileiras Forebrain, Neurolabs e o Laboratório de Neurociência da Faculdade Getúlio Vargas. Essa população foi escolhida pela facilidade de acesso aos profissionais em questão, bem como à reputação de seus estudos em publicações sobre o tema em questão e repercussão de seus trabalhos.

A descrição completa do protocolo da pesquisa segue na Tabela 2:

Tabela 2 - Protocolo da Pesquisa

\section{PROTOCOLO}

\section{Atividade :}

\section{Acadêmicos}

\section{Instrumentistas}

\section{Participantes}

6

7

A seleção final, portanto, deu-se por conveniência e foi formada pela lista de profissionais a seguir, dividida em dois grupos.

Como acadêmicos foram classificados aqueles profissionais que mantinham algum tipo de vinculo acadêmico durante o período da realização da pesquisa. O grupo é composto por seis indivíduos, mais precisamente:

-Prof. Dr. Gerald Zaltman - Professor of Business Administration Emeritus - Harvard Business School http://www.olsonzaltman.com/

-Prof. Dr. Carl D. Marci - Professor do MIT e Neurocientista e Presidente da Empresa de Pesquisa Innerscope Research - Boston, Estados Unidos da America http://www.innerscoperesearch.com/flat/ourcompany.html

-Prof. Dr. Michael Brammer PhD - Neurocientista da Universidade de Londres e Presidente da Empresa Neurosense Institute - Inglaterra http://www.neurosense.com/

-Prof. Dr. M.Vinicius C. Baldo - Neurocientista - Instituto de Ciências Biomédicas Universidade de São Paulo; http://www.fisio.icb.usp.br/orientadores_pos.html

-Prof. Dr. Luiz E. Ribeiro do Valle - Neurocientista - Instituto de Ciências Biomédicas Universidade de São Paulo; http://www.fisio.icb.usp.br/orientadores_pos.html

-Prof. Dr. Fabio Babiloni - Universidade La Sapienza - Roma http://www.uniroma1.it/ Os participantes classificados como instrumentistas são aqueles que no momento da pesquisa de campo possuem vínculos como profissionais envolvidos no oferecimento de pesquisa de mercado sobre comportamento de consumidor. Mais precisamente o grupo é composto por: 
-Prof. Dr. David Lewis - Neurocientista do Departamento de Psicologia Experimental, The University of Sussex, e atual Diretor e fundador da Empresa de Pesquisa TheMindlab International http://www.themindlab.org/

-Sra. Silvia Quintanilha - Vice-presidente da Milward Brown International Brasil http://www.millwardbrown.com/Home.aspx

-Prof. Dr. Billy E. M. Nascimento - Neurocientista e Diretor Executivo e Fundador Instituto Forebrain - neuromarketing Brasil http://www.forebrain.com.br/

-Sr. Karl Rosenberg - Mestre em psicologia social e experimental e Vice-presidente Senior da MSW/LAB Biometrics Insights http://mswresearch.com/research_biometric.html

-Prof. Dr. Philip Rosenberg - Psicólogo, Phd Design de informação e Vice-Presidente da One to One Insight. http://www.onetooneglobal.com/

-Sr. Pedro Camargo - Advogado e sócio da Empresa - Neurolabs. http://neurocurso.com/

-Sr. Carlos Augusto Costa - Eng. Eletrônico e Coordenador Laboratório de Neuromarketing da Faculdade Getúlio Vargas

http://www.fgv.br/fgvprojetos/novoprojetos/Eventos/Detalhe.aspx?ID=eXqfENsmJWZ6 x3u\%2B2ERNcA\%3D\%3D

\subsection{Procedimentos Analíticos}

O método de análise dos dados escolhidos no estudo foi a análise de conteúdo, baseado em Bardin (2007). A autora define esta análise como um conjunto de técnicas de análise das comunicações visando obter por procedimentos sistemáticos e objetivos de descrição do conteúdo das mensagens que possuam indicadores, quantitativos ou não, que permitam a inferência de conhecimentos relativos às condições de produção/recepção, suas variáveis inferidas nas mensagens. O que se busca é a correspondência entre as estruturas semânticas ou linguísticas e as estruturas psicológicas ou sociológicas dos entrevistados.

De acordo com Moraes (1999) essa metodologia de pesquisa faz parte de uma busca teórica e prática, com um significado especial no campo das investigações sociais. Constitui-se bem mais do que uma simples técnica de análise de dados, representando uma abordagem metodológica com características e possibilidades próprias; em qualquer de suas abordagens fornece informações complementares ao leitor crítico. Segundo Olabuenaga e Ispizua apud 
Moraes (1999), a análise de conteúdo é uma técnica para ler e interpretar o conteúdo de toda classe de documentos, que analisados adequadamente abrem as portas ao conhecimento de aspectos e fenômenos da vida social que de outro modo seriam inacessíveis.

A análise de conteúdo, de acordo com Bardin (2007) é um método empírico que depende do tipo de comunicação (oral ou escrita) a que se dedica e do tipo de informação que se espera como resultado. O Quadro 10 detalha os possíveis campos de investigação analisados por esse método e as razões de sua eleição, claramente descritas por oferecer domínio linguístico oral, por comunicação dual ou dialógica e conversas ou entrevistas passíveis de análise, de acordo com tabela sobre campos de aplicação de análise de conteúdo de Bardin (2007):

Quadro 10 - Domínios possíveis da análise de conteúdo

\begin{tabular}{|c|c|c|c|c|}
\hline \multirow[b]{2}{*}{ Código e suporte } & \multicolumn{4}{|c|}{ Número de pessoas implicadas na comunicação } \\
\hline & $\begin{array}{l}\text { Uma pessoa } \\
\text { "monól\$se» }\end{array}$ & $\begin{array}{c}\text { Comunicação duat } \\
\text { «diálogo» }\end{array}$ & Grupo restrito & Comunicação de massa \\
\hline LINGUÍSTICO & & ? & & \\
\hline Escrito & $\begin{array}{l}\text { Agendas, maus pensa- } \\
\text { mentos, congemina- } \\
\text { ções, diários íntimos. }\end{array}$ & $\begin{array}{l}\text { Cartas, respostas a } \\
\text { questionários, a testes } \\
\text { projectivos, trabalhos } \\
\text { escolares. }\end{array}$ & $\begin{array}{l}\text { Ordens de serviço numa } \\
\text { empresa, todas as comu- } \\
\text { nicações escritas troca- } \\
\text { das dentro de um grupo. }\end{array}$ & $\begin{array}{l}\text { Jornais, livros, anúncios } \\
\text { publicitários, cartazes, } \\
\text { literatura, textos jurídi- } \\
\text { cos, panfletos }\end{array}$ \\
\hline Oral & $\begin{array}{l}\text { Delírio do defnte men- } \\
\text { tal, sonhos }\end{array}$ & $\begin{array}{r}\text { Entrevistas e conversa } \\
\text { de qualquer espécie. }\end{array}$ & $\begin{array}{l}\text { Discussões, entrevistas, } \\
\text { conversas de grupo } \\
\text { de qualquer natureza. }\end{array}$ & $\begin{array}{l}\text { Exposições, discursos, } \\
\text { rádio,televisão, cinema, } \\
\text { publicidade, discos. }\end{array}$ \\
\hline $\begin{array}{l}\text { ICÓNICO (sinais, grafismos, imagens, } \\
\text { fotografias, filmes, etc.). }\end{array}$ & $\begin{array}{l}\text { Garatujas mais ou } \\
\text { menos automáticas, } \\
\text { grafitos, sonhos. }\end{array}$ & $\begin{array}{l}\text { Respostas aos testes } \\
\text { projectivos, comuni- } \\
\text { cação entre duas } \\
\text { pessoas através da } \\
\text { imagem. }\end{array}$ & $\begin{array}{l}\text { Toda a comunicação icó- } \\
\text { nica num pequeno gru- } \\
\text { po(p. ex.: símbolos icó- } \\
\text { nicos numa sociedade } \\
\text { secreta, numa casta...). }\end{array}$ & $\begin{array}{l}\text { Sinais de trânsito, cine- } \\
\text { ma, publicidade, pin- } \\
\text { tura, cartazes, tele- } \\
\text { visão. }\end{array}$ \\
\hline $\begin{array}{l}\text { OUTROSCÓDIGOSSEMIÓTICOS (i.e, } \\
\text { tudo o que não sendo linguístico } \\
\text { pode ser portador de significados; } \\
\text { ex.: música, código olfactivo, ob- } \\
\text { jectos diversos, comportamentos, } \\
\text { espaço, tempo, sinais patológicos, etc.). }\end{array}$ & $\begin{array}{l}\text { Manifestações histéri- } \\
\text { cas da doença mental, } \\
\text { posturas, gestos, ti- } \\
\text { ques, dança, colecções } \\
\text { de objectos. }\end{array}$ & $\begin{array}{l}\text { Comunicação não verbal } \\
\text { (posturas, gestos, dist } \\
\text { olfactivos, manifestaçõ } \\
\text { quotidianos, vestuário, } \\
\text { tamentos diversos, tais c } \\
\text { de cortesia. }\end{array}$ & $\begin{array}{l}\text { al com destino a outrem } \\
\text { stância espacial, sinais } \\
\text { ôes emocionais, objectos } \\
\text {, alojamento...), compor- } \\
\text { como os ritos e as regras }\end{array}$ & $\begin{array}{l}\text { Meio físico e simbólico: } \\
\text { sinalização urbana, } \\
\text { monumentos, arte...; } \\
\text { mitos, estereótipos, } \\
\text { instituições, elementos } \\
\text { de cultura. }\end{array}$ \\
\hline
\end{tabular}

FONTE: BARDIN, 2007, p. 30.

O método de análise de conteúdo foi baseado em entrevistas em profundidade onde a base da informação é proveniente de uma conversa dialógica. A análise começa por uma descrição da comunicação oriunda da entrevista, sua transcrição e leitura, e termina por uma interpretação de suas características, por determinação de seus índices e inferências que permitem análise quantitativa, fundamentada na frequência da aparição dos elementos da mensagem, ou qualitativa, com seus elementos não frequentes que permitem inferências. 
No método, baseado em Bardin (2007) o que se vê é uma análise em um plano horizontal para o texto e sua análise descritiva e plano diacrônico ou vertical para variáveis inferidas. $\mathrm{O}$ método é realizado em três fases. São elas:

- Pré-análise: onde é realizada a organização do material, isto é, formulação das hipóteses e os objetivos e busca de indicadores, por meio de leitura flutuante.

- Exploração do material: onde se dá a administração sistemática das decisões tomadas, com procedimentos aplicados manualmente ou por meio de operações computadorizadas, de modo a codificar, descontar e enumerar em função das regras previamente formuladas.

- Tratamento dos resultados e interpretações: onde os resultados são tratados de maneira a serem significativos e válidos. Aqui são aplicadas operações estatísticas simples ou complexas que permitem estabelecer quadros de resultados, diagramas, figuras e modelos que condensam e põem em relevo as informações fornecidas pela análise. A partir da validação dos resultados inferências e interpretações são propostas de acordo com os objetivos previstos ou outras descobertas inesperadas. A Ilustração 25 apresenta o desenvolvimento de uma análise, de acordo com a autora: 


\section{Desenvolvimento de uma análise}

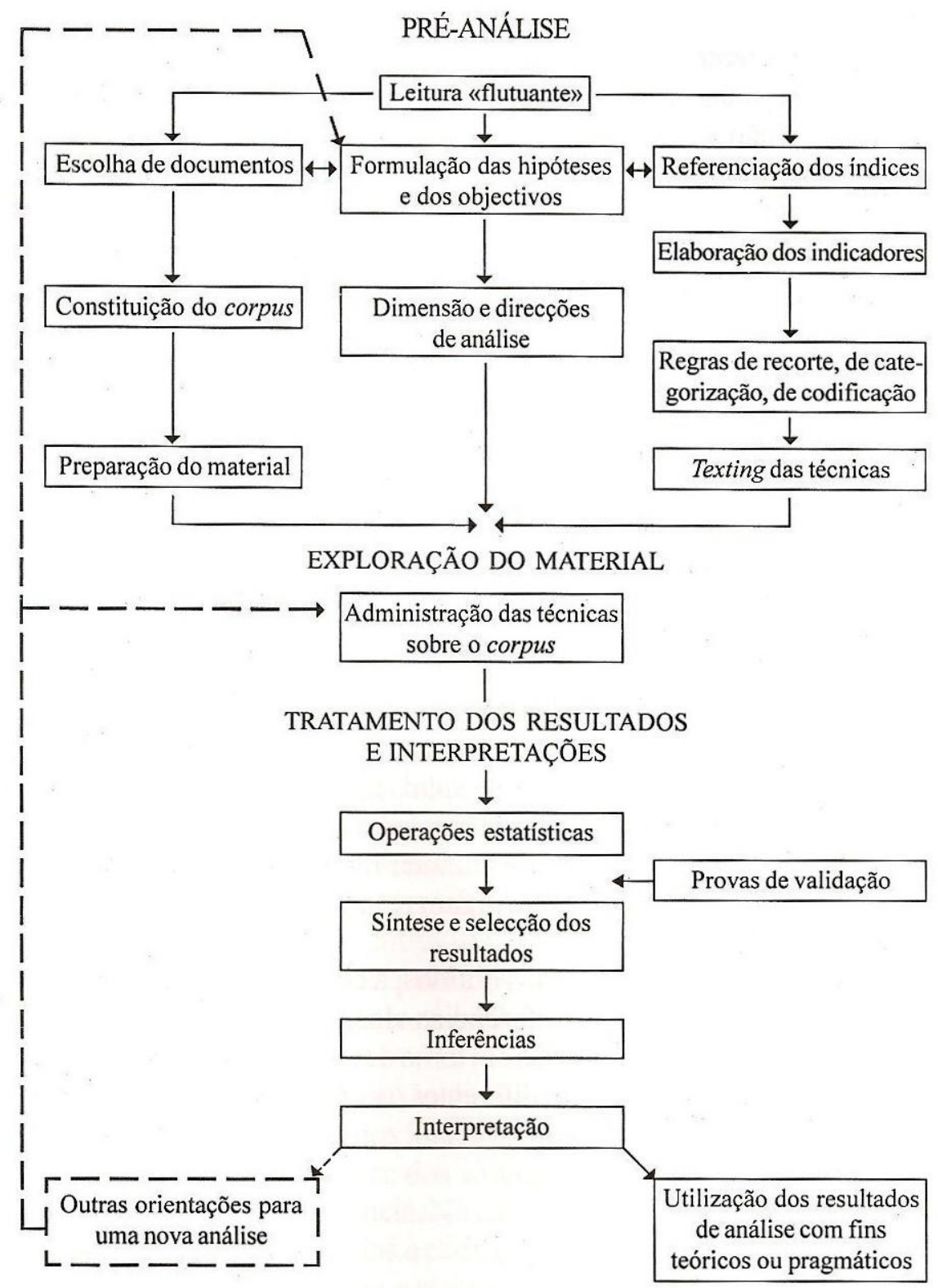

Ilustração 25 - Desenvolvimento da análise de conteúdo FONTE: BARDIN, 2007, p. 96.

De acordo com Moraes (1999) há muitas formas de caracterizar possíveis objetivos de pesquisas realizadas utilizando análise de conteúdo. Entretanto, historicamente, as categorias definidas levam em consideração os aspectos intrínsecos da matéria-prima da análise, o contexto a que as pesquisas se referem e as inferências pretendidas. São definidas seis categorias com seis questões: quem fala; para dizer o quê; a quem; de que modo; com que finalidade; com que resultados. 
O método proposto na análise de conteúdo constitui-se, portanto, em etapas de preparação das informações com sua base unitária ou transformação do conteúdo em unidades; categorização ou classificação das mesmas em categorias; descrição e ao final interpretação. Ao longo da sequência refere-se à análise propriamente dita. No entanto, as etapas precisam ser necessariamente precedidas das definições normais que acompanham um projeto de pesquisa, quais sejam, explicitar um problema, estabelecer claramente seus objetivos e a partir disto reunir os dados previstos pelo projeto.

Pré-análise ou preparação e base unitária

$\mathrm{Na}$ fase atual, uma vez de posse das informações a serem analisadas é preciso submetê-las a um processo de preparação identificando diferentes amostras, estabelecendo um código que possibilite identificar rapidamente cada elemento da amostra de depoimentos, que facilite orientar o pesquisador para retornar a um documento específico quando assim o desejar. Uma vez devidamente preparados, os dados são submetidos à base unitária, ou unidade de análise ou registro que será classificado. Estas podem ser palavras, frases, temas ou mesmo documentos em sua forma integral.

Para Bardin (2007) a pré-análise é a fase de organização, que tem por objetivo tornar operacionais as ideias iniciais e sistematizá-las conduzindo a um esquema de desenvolvimento das operações seguintes, num plano de análise.

Dentro do roteiro proposto, por meio de uma leitura flutuante, foram elaborados e referenciados 10 principais tópicos ou indicadores/índices, temas esses encontrados nos documentos do material recolhido. Esses temas constituem as categorias, que têm por base a fundamentação teórica da pesquisa e o principal critério foi semântico ou categorias temáticas. São elas: Envolvimento com Comportamento; Razões para o estudo; Envolvimento com a neurociência e as técnicas mais familiares; Definição do neuromarketing, possibilidades de medições; Possibilidades nas fases de marketing; Técnicas utilizadas; Vantagens e Limitações; Preocupações; Futuro; Fontes de informações.

É importante notar que para a definição dos sistemas de categorias, deve-se estabelecer a regra de enumeração: determina-se um conjunto de textos, verifica-se a presença ou ausência de elementos e calcula-se a frequência desses elementos. Quanto maior a frequência de 
aparição, maior será a importância de uma unidade de registro. Outra regra é a ponderação, se houver a suposição de que a aparição de determinado elemento tem mais importância que outro, calcula-se a frequência ponderada. Além disso, deve-se considerar a intensidade ou medição das variações semânticas em uma classe de elementos.

\section{Exploração do Material}

Concluída essa etapa, iniciou-se a fase do inventário dos elementos, ou seja, a definição das unidades de registro e das unidades de contexto em uma operação de classificação por conjunto ou diferenciação. As categorias reúnem um grupo de unidades de registro sob um título genérico, agrupadas em razão de características comuns encontradas nas unidades. O critério de categorização pode ser semântico - por significado; sintático - verbos, adjetivos; lexical - por palavras e seus sentidos; expressivo - classificando diversas expressões de linguagem.

O sistema de categorias é fornecido a partir da teoria que suporta a pesquisa ou resultado da análise progressiva dos elementos do texto, mas pode ser misto. Neste estudo, aplica-se o tema como unidade de registro, e o sistema de categorias como resultado progressivo dos elementos presentes nas entrevistas, visto que as respostas às questões abertas e às entrevistas individuais são comumente analisadas tendo o tema como base e guia do roteiro seguido.

Em seguida, a sua classificação de acordo com os índices representados. Dessa forma, foi possível organizar os trechos, obedecendo-se aos critérios sugeridos por Bardin (2007): cada elemento está restrito a uma divisão, por exclusão mútua; em cada categoria há diferentes dimensões de análise; cada categoria está adaptada ao material de análise escolhido e pertence ao referencial teórico definido; as categorias são definidas, na medida do possível, para evitar subjetividade.

Um exemplo descrito na Tabela 3 é a categorização do que o painel acredita ser possível medir em marketing com o neuromarketing. O que se notou é que dentro do índice a ser estudado existem 12 possíveis subclassificações - qualificações indicadas pelo painel, de forma não excludente, mencionadas pelos indivíduos e aglomeradas entre si: marca, ideia, protótipo, propaganda, impresso, musica/jingle, ponto de venda, loja virtual, sensorial/fragrância, preço, interatividade/navegabilidade e emoção. Em negrito 
primeiramente destacou-se o público acadêmico, sempre na busca de levantar algum tipo de alinhamento ou concordância sobre a categoria estudada; após isso se busca contar as respostas, nesse caso, múltiplas, sobre as hipóteses do índice.

$\mathrm{Na}$ classificação das respostas em categorias e, dentro delas, em possíveis explicações, a intenção é encontrar conclusões além da literatura anteriormente explorada para agregar conhecimento ao estudo proposto. A análise ainda é enriquecida pela contagem, ou seja, o elemento quantitativo adicionado pelo método proposto com base em Bardin (2007).

Tabela 3 - Neuromarketing: o que se mede em marketing

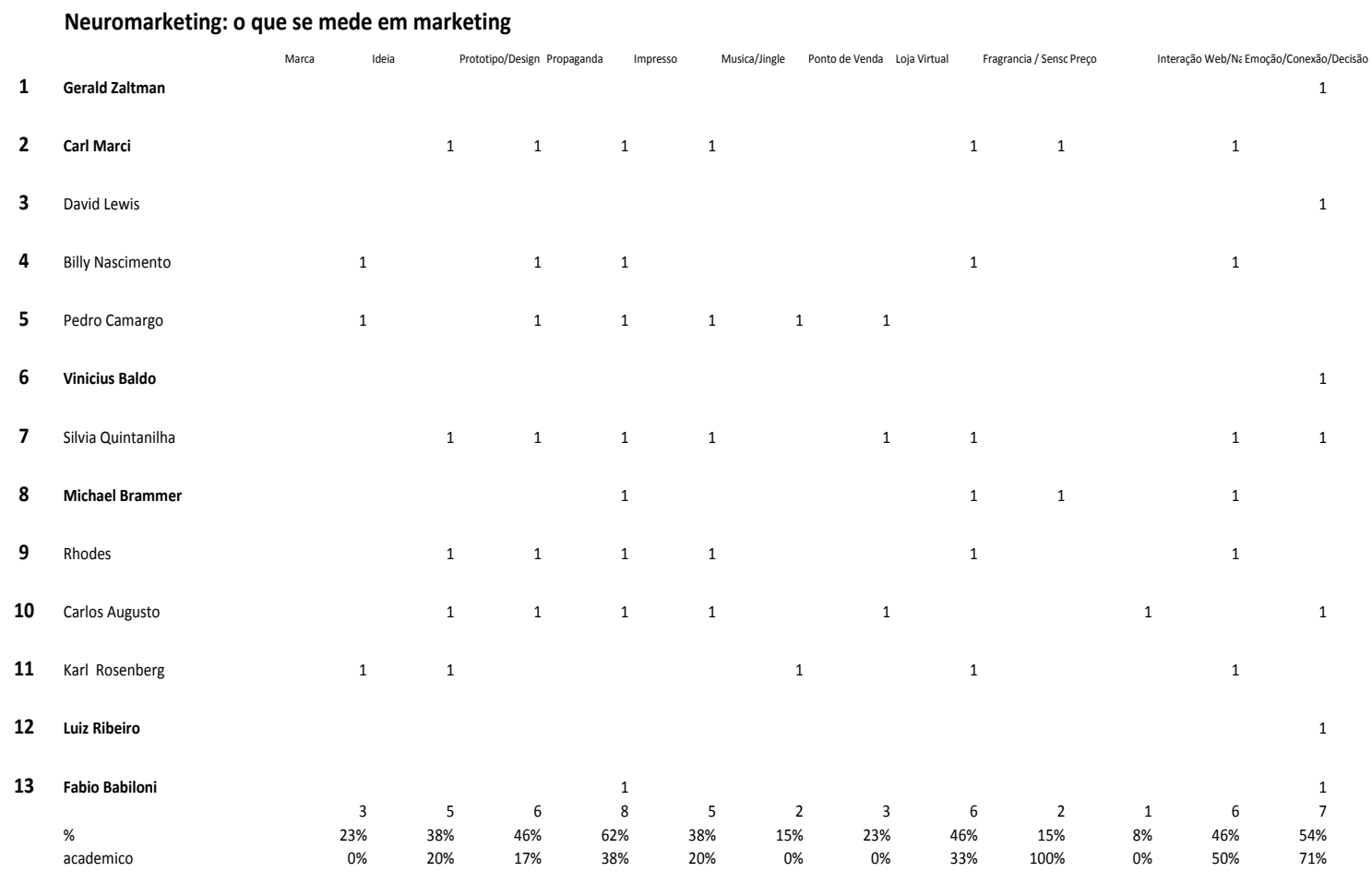

Uma vez finalizada a exploração de todas as categorias materiais, a etapa seguinte é a contagem dos trechos e elaboração de tabelas que permitem condensar e destacar informações. Em cada categoria são analisados os resultados e suas totalidades.

Tratamento dos Resultados e Interpretações

A última etapa da análise de conteúdo consiste na busca de um tratamento numérico, estatístico simples dos resultados obtidos. Esta fase permite a elaboração de tabelas que condensam e destacam informações fornecidas para a análise. $\mathrm{O}$ tratamento permite inferir e interpretar as mensagens, ou conteúdo, das diversas entrevistas transcritas. Cada entrevista foi 
subdividida primeiramente entre os dois perfis de entrevistados: acadêmicos, na Tabela 3 mencionada estão em negrito e serão sempre destacados; e os instrumentistas, ou aqueles que no momento desempenham um papel em empresas de pesquisa de mercado estudando e comercializando resultados sobre comportamento. Após a divisão de públicos, por navegação nas transcrições buscou-se identificar, dentro do índice a ser analisado, nesse caso as razões ou motivações pelo entendimento do comportamento, seus principais indicadores presentes nas tabelas de tabulação, que no caso em referência foram encontrados como busca básica de informação para minha profissão, aprofundamento das áreas em estudo ou apenas curiosidade.

A análise foi manual, com a devida contagem e enumeração das respostas pelos entrevistados. O tratamento de dados foi realizado evidenciando-se os resultados mais presentes, destacando-se características relevantes e válidas para fins de interpretação. As tabelas em sua totalidade estão disponíveis em Anexos. A análise teve por finalidade oferecer informações suplementares que não teriam sido percebidas pela pesquisa de outra maneira. 


\section{ANÁLISE DA PESQUISA EMPÍRICA}

Este capítulo destina-se à análise de dados. Inicia-se com a explicação dos dados de coleta, a caracterização da amostra e seu detalhamento. Ao final, é feita uma análise dos dados propriamente dita que seguiu os procedimentos da análise de conteúdo. Finaliza-se este capítulo com as conclusões da pesquisa de campo.

\subsection{Coleta de Dados}

O primeiro procedimento para a coleta de dados foi a marcação das entrevistas de profundidade. Já foi explicitado que essas foram realizadas por telefone ou Skype, seguindo um roteiro no idioma original do entrevistado. Todas foram gravadas e transcritas e traduzidas para o português, eliminando assim imprecisões e aumentando o acesso de seus dados na íntegra.

Iniciou-se com perguntas sobre os entrevistados como sua formação, sua experiência, seu envolvimento com comportamento do consumidor, seu trabalho atual, localização, função atual.

A Tabela 4 contém a divisão dos entrevistados e suas respectivas formações. A amostra contém 13 profissionais envolvidos de alguma forma com a neurociência e sua aplicação com comportamento. A amostra é composta por sete pessoas estrangeiras, sendo quatro americanas, duas inglesas, uma italiana e seis brasileiras. As profissões mais frequentes são: Medicina e Psicologia, com três pessoas cada, seguida de Administração e Engenharia elétrica, com dois indivíduos. Existem outras profissões, com um indivíduo a nomear: biomédico, advogado, químico, comunicação e filosofia. Importante citar que metade da amostra apresenta mais de uma formação, buscaram ampliar seus conhecimentos. 
Tabela 4 - Diversidade de formação

\section{Formação do Painel 13 participantes - resposta multipla}

Doutorado —Academico Hoje associações Academicas Instrumentista

9

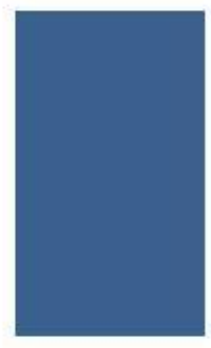

7

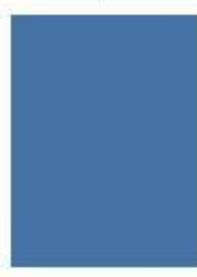

8

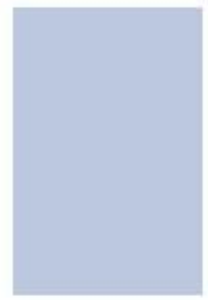

Com formação seja em pós-graduação ou doutorado, existem nove pessoas, a maioria do painel. Entre as pessoas com doutorado, a maior frequência (3) é de neurocientistas, seguida de psicólogos (2), seguido ainda de sociólogo, psiquiatra, designer de informação e engenheiro de computação. Entre os acadêmicos o doutorado mais frequente é psicologia e neurofisiologia.

Como já mencionado anteriormente, a partir deste momento chama-se de acadêmicos somente aos indivíduos que na atualidade estão ligados à universidade. $\mathrm{Na}$ amostra temos seis, que correspondem a $46 \%$ da amostra. O grupo é composto por dois participantes do Instituto de Ciências Biomédicas da Universidade de São Paulo, dois membros de universidades americanas (Universidade de Harvard e MIT), um da Universidade de Sussex na Inglaterra e por último um professor da Universidade de Sapienza de Roma.

O restante, $54 \%$ da amostra, serão chamados de instrumentistas. Eles são compostos por executivos das respectivas empresas: MindLab, Forebrain, Milward Brown, NeuroSense, One to One Insight, Laboratório da Faculdade Getúlio Vargas e MSW Research.

\subsection{Análise de dados}

A análise foi iniciada levando-se em consideração a teoria de Bardin (2007), que contempla a preparação dos materiais coletados nas gravações e suas devidas transcrições. Os textos foram 
copiados em sua íntegra, traduzidos, no caso das entrevistas realizadas em outro idioma (inglês) e sintetizados, eliminando repetições em trechos relevantes para a pesquisa.

Os temas, que seguiram um roteiro, foram eleitos e categorizados segundo os temas abaixo:

- Envolvimento com Comportamento;

- Razões para o estudo;

- Envolvimento com a neurociência e as técnicas mais familiares;

- Definição do neuromarketing, possibilidades de medições;

- Possibilidades nas fases de marketing;

- Técnicas utilizadas;

- Vantagens e Limitações;

- Preocupações;

- Futuro;

- Fontes de informações.

Esses temas constituem as categorias ou índices, separados e agrupados por categorização semântica entre os depoimentos realizados. A etapa seguinte da análise consistiu na definição das proposições que representam cada uma das categorias. Nessa nova fase verificou-se a necessidade de criar subcategorias para facilitar a análise e outros agrupamentos, elemento presente em quase todas as categorias, para qualificar e facilitar assim a análise do conteúdo e a menção dos indicadores.

Concluída essa etapa, iniciou-se o inventário dos elementos e sua classificação de acordo com as proposições que representam cada uma das categorias; dessa maneira foi possível repartir e organizar os trechos dos depoimentos.

Uma vez finalizada a exploração do material teve início a contagem dos trechos e a elaboração de tabelas que permitem condensar e destacar as informações coletadas. Em cada categoria são analisados os resultados de cada um dos entrevistados e as totalidades das proposições, agrupando-os por similaridade e diferença e suas conclusões. As mesmas, para facilitar o entendimento, foram exploradas em cada uma das categorias em forma de gráficos interpretativos, que visualmente tentam endereçar as conclusões em cada caso. 
$\mathrm{Na}$ sequência, apresentam-se as análises da pesquisa de acordo com as categorias mencionadas.

\subsubsection{Envolvimento com Comportamento}

O primeiro tópico explorado foi o envolvimento dos entrevistados com o estudo do comportamento. Os indicadores encontrados para as respostas foram: base de formação, que se entende ser a formação acadêmica principal, ou aprofundamento na área de estudo, requisições posteriores à formação que exigiram a investigação do tópico mencionado. Houve uma menção apenas à exceção dos dois indicadores mencionados que o envolvimento tenha sido proveniente da curiosidade.

Dos números encontrados temos cinco pessoas que se envolveram com o estudo do comportamento desde o princípio de sua carreira e outras sete que estudaram o assunto posteriormente, como exigência de sua carreira seja acadêmica ou de instrumental.

\subsubsection{Razões para o estudo}

Tabela 5 - Razões para estudar comportamento

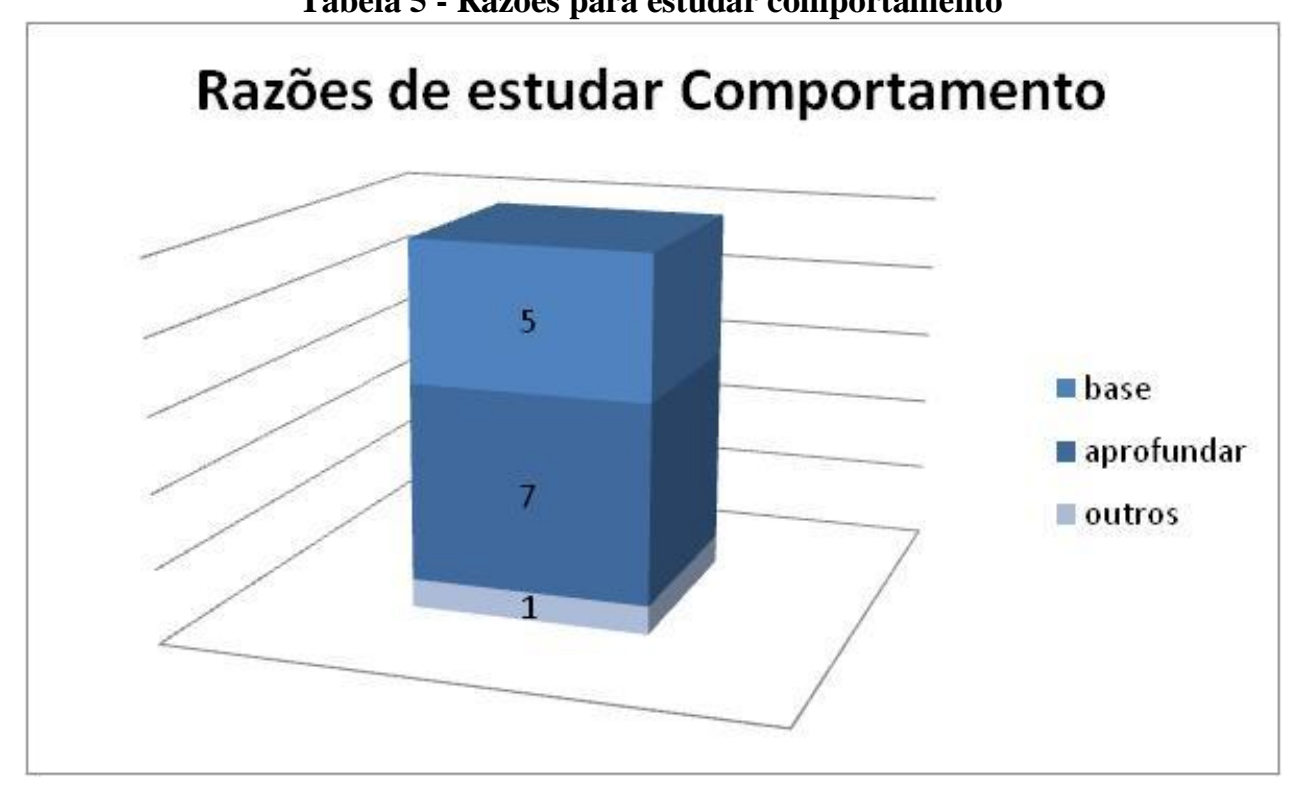

As razões para o envolvimento com o comportamento mencionadas durante as entrevistas foram diversas, porém classificadas e estão indexadas em três grandes blocos, conforme demonstra o Tabela 5. O primeiro é composto por aqueles indivíduos onde o entender o comportamento faz parte integrante da escolha profissional, isto é, seu estudo é parte integral 
de sua formação. Foram feitas menções de que se estuda o tema desde o início da faculdade, ou desde quando começou a exercer sua profissão. O segundo bloco é formado por aqueles onde entender o comportamento foi uma forma de evoluir em sua profissão ou prática, isto é, trouxe algo adicional ou complementar a sua atividade profissional. Aqui houve menção a fatores diversos, como, para o entendimento do estresse buscou-se analisar e estudar comportamentos de guerra durante os estudos de medicina, ou ainda a análise de comportamentos emocionais foi importante para entender melhor o processo de visão no estudo da neurobiologia. No terceiro bloco, composto por outras razões surgiram temas diversos. Desta forma, vê-se que a familiaridade com o tema é grande, pois entre os 13 participantes do estudo, 12 conhecem o assunto.

\subsubsection{O envolvimento com a neurociência e as técnicas mais familiares}

O próximo tópico avaliado foi o envolvimento com a neurociência, onde se encontrou três índices: o envolvimento para entender a reação dos indivíduos; por interesse comercial sobre o assunto; ou ainda para entender doenças como depressão ou estresse. Nesse ponto obteve-se que a maioria dos acadêmicos - cinco de um total de seis - envolveu-se com essa área por querer entender algum tipo de reação do indivíduo em estudo. Os instrumentistas envolveramse com o tema por necessidade de complementar os métodos de pesquisa a ser comercializada, quatro dos instrumentistas. Entender doenças foi o terceiro da lista, com dois casos, sendo um acadêmico e um instrumentista.

As técnicas conhecidas para análise dos indivíduos na neurociência mais conhecidas em respostas não exclusivas, são em ordem de importância: biometria, com nove casos, respostas elétricas do cérebro (EEG) com seis casos, e estudos utilizando imagem, com dois casos, conforme Tabela 6 .

É importante mencionar que os estudos de imagem são dominados por acadêmicos, o que evidencia as informações obtidas no capítulo anterior quanto às barreiras de utilização da técnica no meio comercial: assertividade de resultados e interpretações, aplicação do método nos indivíduos durante atividades corriqueiras e custo da técnica. 
No meio dos instrumentistas há a utilização predominantemente da biometria e análise das ondas elétricas do escalpo (EEG). Em quatro das seis menções os dois estudos são realizados em combinação, e somente em dois casos predomina puramente a biometria.

Novamente há a comprovação de que comercialmente as duas técnicas são mais facilmente aplicadas em laboratório, promovendo assim seu maior emprego no mercado. Dados como capacete de aplicação de EEG e cintas ou acessórios, que acompanham o indivíduo em sua experiência, facilitariam a aplicação comercial e também as simulações de situações mercadológicas

Tabela 6 - Técnicas utilizadas na neurociência

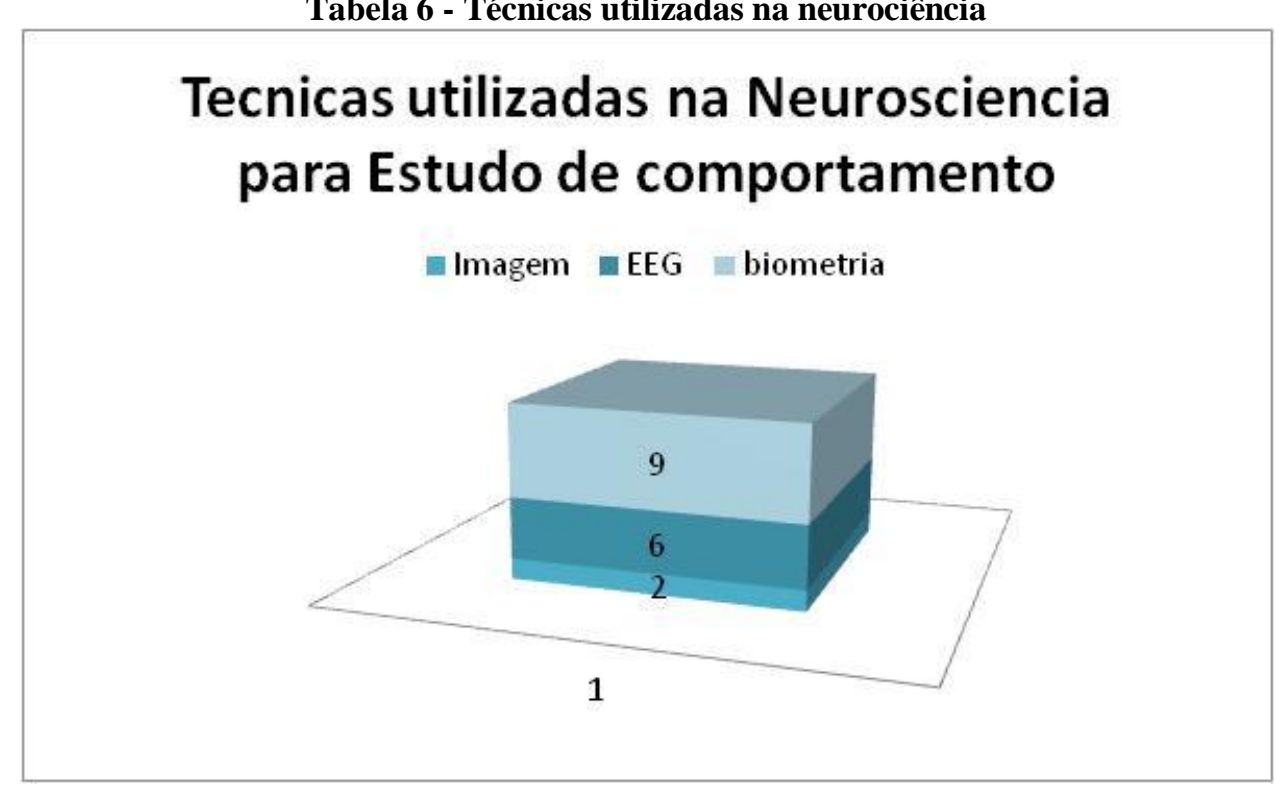

\subsubsection{Definição do neuromarketing}

A partir do entendimento da relação com a neurociência e suas técnicas avaliou-se o conhecimento da definição de neuromarketing. Os indicadores mais presentes foram: aplicação dos conhecimentos e técnicas da neurociência e entender o implícito.

O resultado obtido dos indicadores por segmento de entrevistado foi que o conceito preferido entre acadêmicos, com a totalidade de sua representação na amostra, é a de que o neuromarketing é uma aplicação da neurociência em investigações mercadológicas. Outras três declarações oriundas dos instrumentistas também citam o mesmo conceito como preferido, totalizando, portanto que oito participantes entendem o neuromarketing com uma 
aplicação da neurociência, não evidenciando a área em questão como uma nova ciência, como demonstrado na Tabela 7.

Tabela 7 - Conceito de neuromarketing

\title{
Conceito Neuromarketing
}

\author{
- aplicação dos conhecimentos/tecnicas da neurosciencia \\ nentender o implicito /não cognitivo
}

9

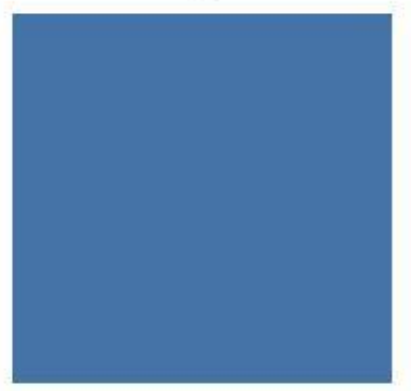

4

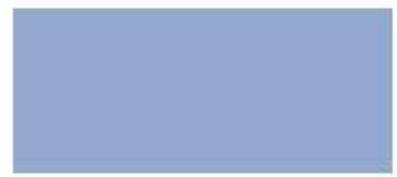

Os outros quatro participantes da amostra, em sua totalidade instrumentistas, denominam o neuromarketing como uma forma de entender o não cognitivo ou inconsciente. Caracteriza-se assim uma tendência mercadológica de destacar o tema como uma nova ciência, ou campo e não uma proveniente ou aplicação de neurociência.

Além de buscar a denominação do que seria o neuromarketing, na opinião do painel de respondentes, houve uma preocupação de se explorar o que seria possível mensurar e isso foi extraído do conteúdo declarado pelos indivíduos. Nesse ponto houve uma distribuição quase igualitária de cinco indicadores de medição. São elas: Polaridade de respostas; intensidade; mensuração do inconsciente; o estado mental do indivíduo e resposta ao estímulo, conforme a Tabela 8.

Ficou claro, no entanto, que o grupo composto por acadêmicos, em sua maioria, acredita ser possível mensurar polarização do estímulo, isto é se o mesmo é positivo ou negativo, bem como sua intensidade. Os instrumentistas possuem uma maior distribuição de suas respostas, tais como: retirar respostas da mente, do inconsciente ou mesmo avaliar uma tomada de decisão. 
Cabe aqui a análise de que em decorrência da obtenção de dados dos indivíduos pelos instrumentistas ser proveniente de múltiplas técnicas e necessidade de maiores esclarecimentos e combinações entre os dados, os mesmos concluem que medições biométricas e elétricas podem ser averiguadas posteriormente com questões declaratórias, complementando assim as questões além de sua polaridade e intensidade, e esclarecendo com resultados interpretados de respostas inconscientes.

Tabela 8 - O que é possível medir em neuromarketing

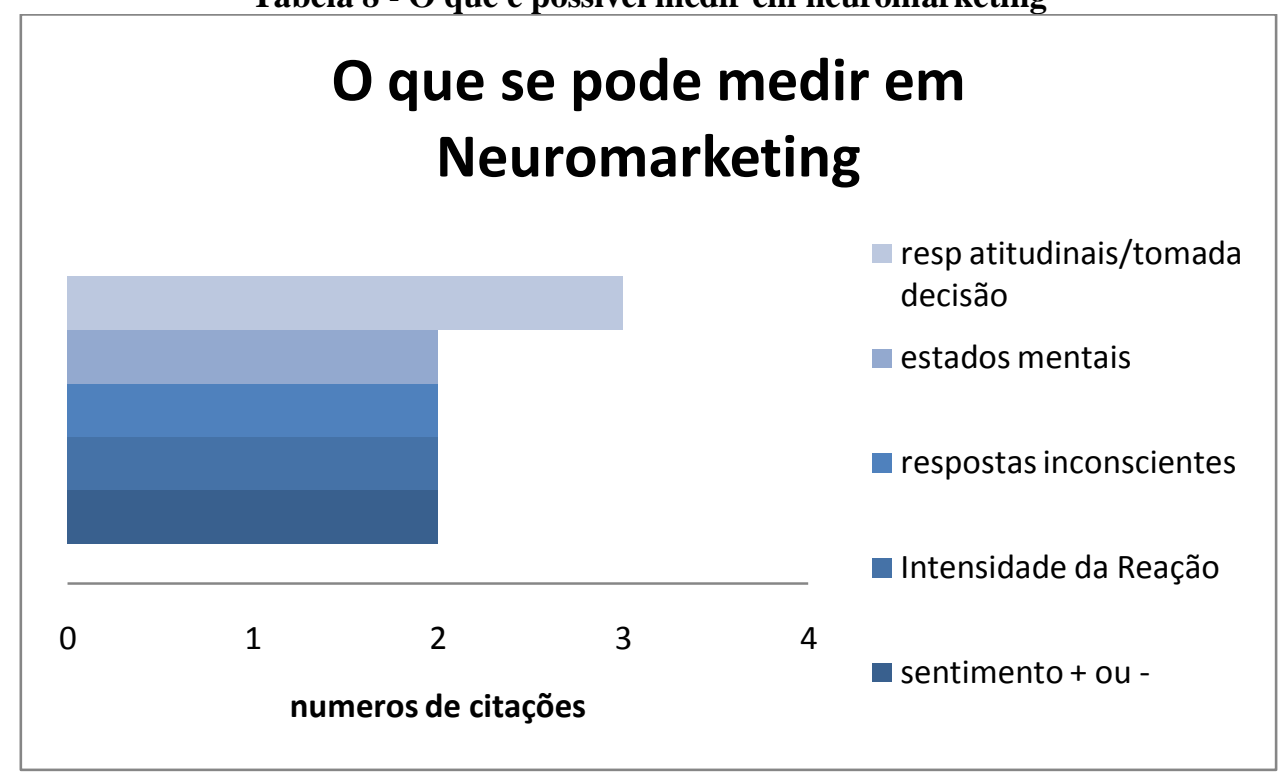

3.2.5

Possibilidades de explorações com neuromarketing para fases de

\section{Marketing}

As áreas passíveis de medições em marketing, eleitas pelo painel estão listadas na Tabela 9. Verifica-se predominância da possibilidade de obtenção de resposta aos estímulos provocados pela comunicação ou propaganda, citado por oito dos respondentes, grupo composto preponderantemente por instrumentistas. Seguida a essa menção, segue a possibilidade de medição da emoção gerada pelo estímulo, declarado por sete dentre os 13 entrevistados, e nesse caso a predominância é de acadêmicos, com cinco do total de sete declarações; em terceiro lugar seguem três itens, sendo dois deles para verificação de estímulos on-line ou na internet como verificação de navegações nas lojas virtuais, simuladores de lojas reais na tela do computador mais utilizadas por instrumentistas, ou mesmo navegação nos sítios da internet ou e-commerce das marcas, mencionados igualmente pelos dois públicos entrevistados. Em um mesmo patamar é elencada também a possibilidade de análise de protótipos de produtos, 
em sua maioria notada no grupo de instrumentistas. Nota-se pouca menção, ou citações por uma ou duas pessoas, à detecção de níveis de preço, música e fragrância como elementos de estímulos de marketing.

Tabela 9 - Diversidade de formação

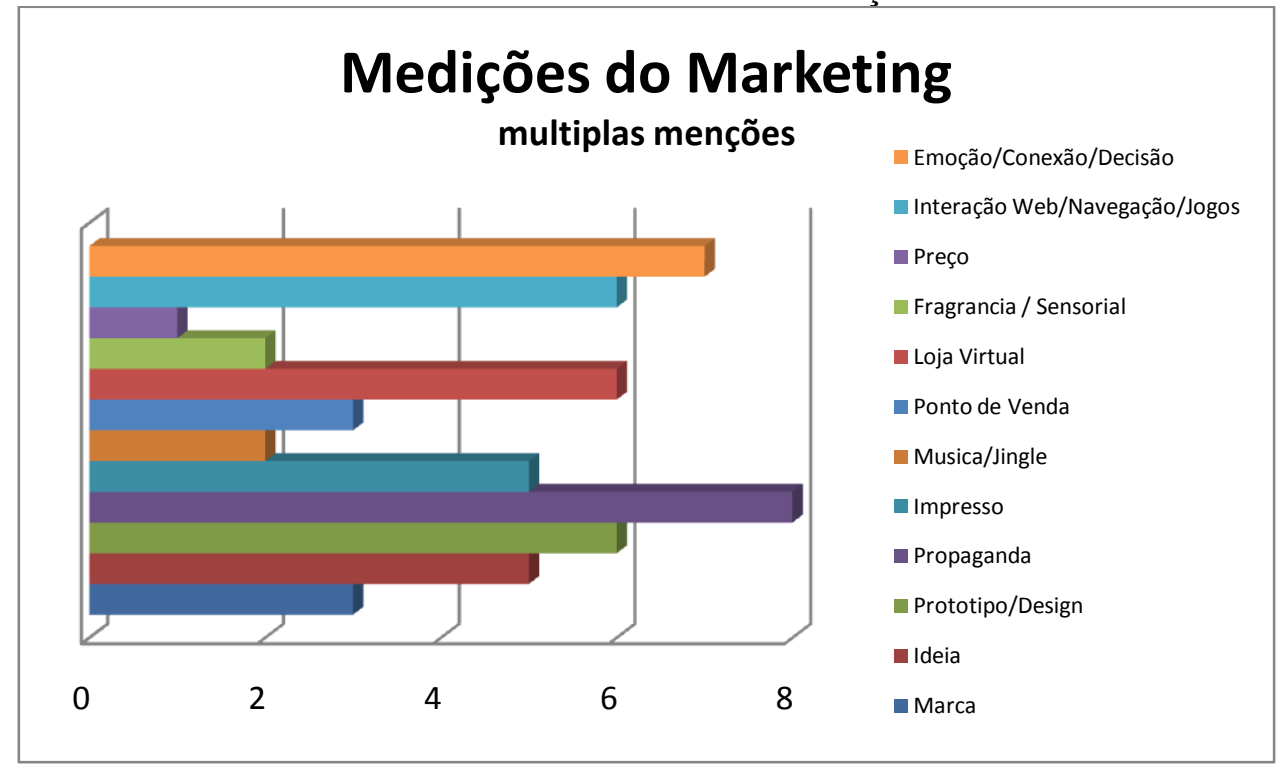

\subsubsection{Técnicas utilizadas no neuromarketing}

Em relação às técnicas empregadas pela amostra na obtenção de seus estudos de comportamento, em respostas múltiplas, existem diversas formas de aplicação, sendo a mais comum a Biometria, presente em 12 respondentes da amostra total. Em seguida há a medição por meio de EEG com 11 menções, e, por último, algum tipo de medição de imagem em oito respondentes, por fMri, conforme demonstrado no Tabela 10. 
Tabela 10 - Técnicas de medição utilizadas

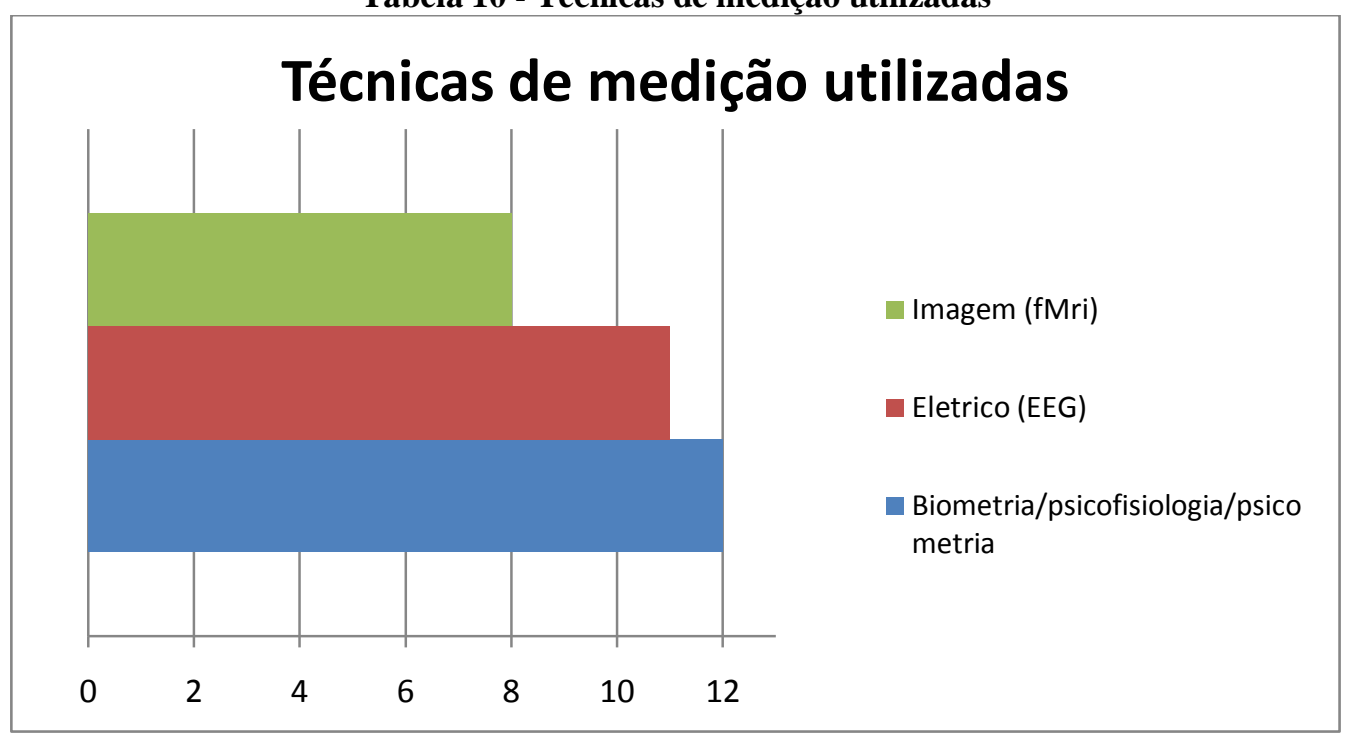

É importante, no entanto, qualificar quais os respondentes que declaram as diferentes técnicas. Entre instrumentistas, a totalidade da amostra declara a biométrica como a técnica mais frequente, a maioria de acadêmicos também se baseia em seus resultados, sendo 12 os participantes da amostra que utilizam a biometria. Nela, menciona-se a utilização de eye tracking, suor, respiração e batimento como as medições mais corriqueiras, ou as reações aos estímulos mensurados com maior frequência.

Para as medições por EEG existe o mesmo número de acadêmicos respondentes, isto significa que 11 pessoas da amostra utilizam o eletroencefalograma. A grande maioria dos instrumentistas utiliza a técnica, seis entre os sete componentes do grupo.

Para imagem, no entanto, o que se observa é que dos oito respondentes, sendo metade do público acadêmico, têm ciência e usa medições por imagem, enquanto cinco entre sete instrumentistas têm o conhecimento apenas, resultado já apurado anteriormente mencionando as possíveis barreiras comerciais de sua utilização pelos instrumentistas.

Outras técnicas são citadas como fontes para o entendimento das reações aos estímulos oriundas de questionários ou dados secundários por sete pessoas da amostra, sendo em quatro respondentes, três instrumentistas. O teste chamado ITA, anteriormente citado, também é citado por um respondente como complementação aos métodos citados, um instrumentista. 


\subsection{7}

Vantagens e Limitações de sua utilização

Como vantagens oferecidas pelo neuromarketing, as mais citadas, como pode ser visto na Tabela 11 são: aumentar o entendimento da mente e inconsciente com a diminuição de incertezas, totalizando $70 \%$ das respostas sobre os respondentes e $44 \%$ dos acadêmicos. A segunda mais citada é a utilização complementar a outros métodos de coleta, citada por $44 \%$ da amostra, igualmente dividida entre os acadêmicos e instrumentistas. Todas as demais vantagens, com exceção da multidisciplinaridade, são respostas provenientes em sua totalidade do grupo de instrumentistas; os acadêmicos limitam-se as duas primeiras respostas, que coincidem com as preferências dos instrumentistas.

Tabela 11 - Vantagens do neuromarketing

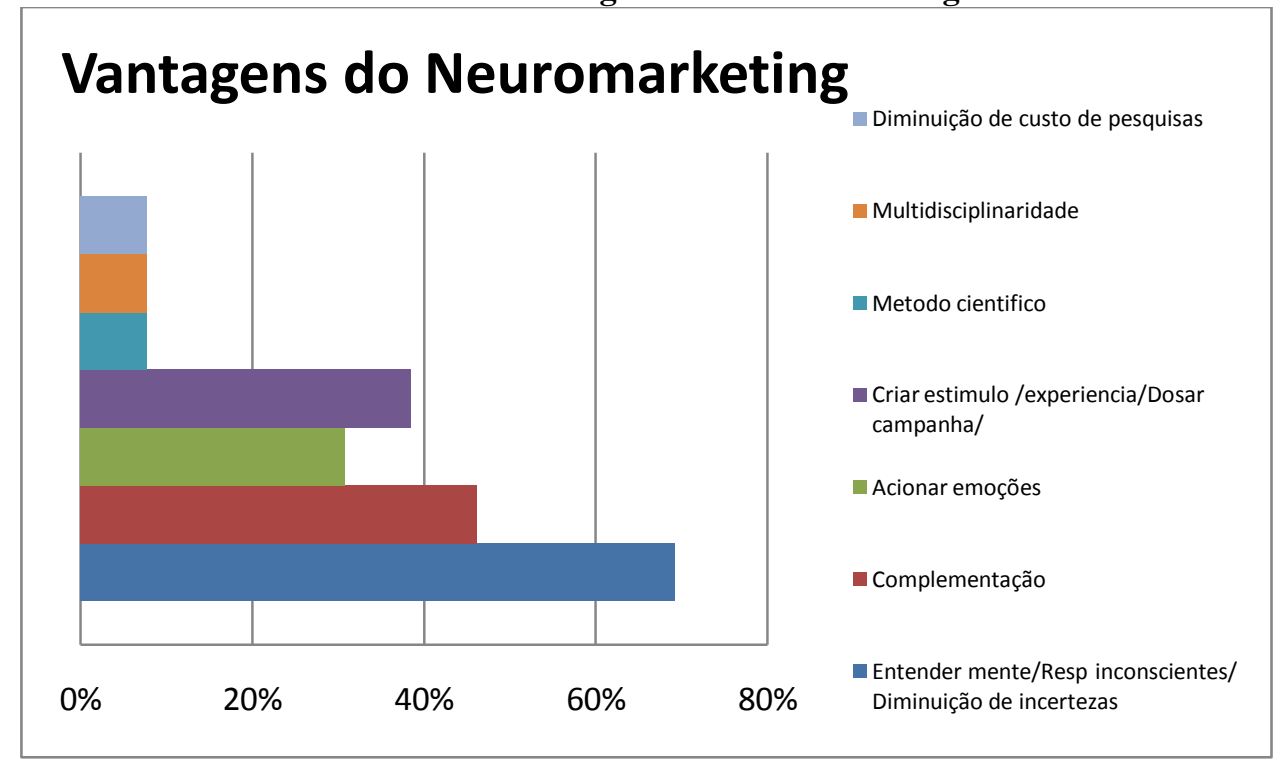

As limitações oriundas do neuromarketing elencadas pelo grupo de estudo foram mencionadas no máximo por cinco respondentes. Portanto, nenhuma limitação listada ultrapassa $40 \%$ da amostra, ou seja, limita-se sempre a uma população reduzida de indivíduos. As citações mais frequentes sobre as restrições do neuromarketing foram: ser um estudo laboratorial - que mede as reações em situações não reais de comportamento dos indivíduos; ter um campo ainda pouco explorado por publicações científicas; apresentar problemas amostrais que possam representar a população; apresentar falta de protocolos acordados e aceitos entre os estudiosos como acordos sobre ferramentas de captura de reações e escalas acordadas de interpretação.

Sobre observações específicas dos grupos apresentados no estudo houve especificidades como o grupo acadêmico, com $50 \%$ da amostra apontando problemas da área de estudo da falta de 
protocolos aceitos em seu meio entre três respondentes dos seis entrevistados; esse grupo também levantou outras limitações importantes como a multiplicidade de métodos de aplicação para investigação de reações comportamentais e a dificuldade de combinação dos dados entre si em diferentes formas de coleta para determinar um diagnóstico, citado por dois respondentes. Vide Tabela 12.

Tabela 12: Limitações do neuromarketing

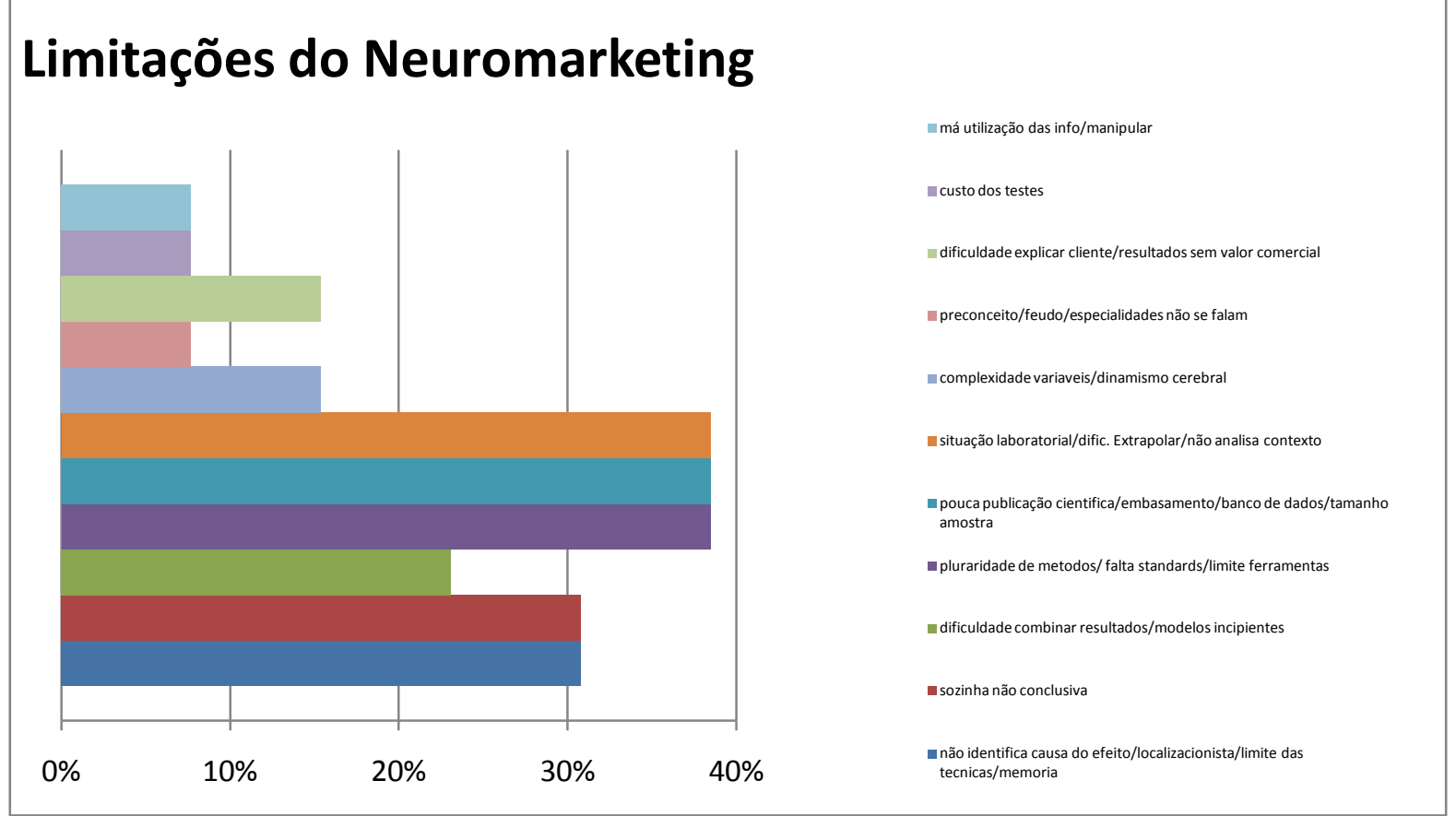

3.2.8

Preocupações sobre o tema

As maiores preocupações da amostra estão resumidas no Tabela 13, onde nove entre os 13 entrevistados preocupam-se com a falta de fundamento dos estudos no que se refere a padrões comumente aceitos, portanto, com a presença de vieses oriundos de interpretações falsas sobre dados coletados de fontes chamadas de blackbox, ou não abertas a análises.

O grupo acadêmico, após a preocupação com a menção acima citada, também reportou a preocupação com o alarmismo ou falta de esclarecimento dos dados de estudo à população, o que pode causar preocupações não fundamentadas. Os instrumentistas, por outro lado, preocupam-se em segundo lugar com a amostra utilizada e sua representatividade populacional. Eles também mencionam preocupação com a formação de acordos protocolares, nesse caso citando a possibilidade de futuras abordagens com o patrocínio da Esomar, European Society for Marketing Research, organização das empresas de pesquisa de mercado 
desde 1948 com base europeia, que organiza códigos de ética e práticas de profissionais da área de pesquisa de mercado (http://beta.esomar.org/uploads/public/aboutesomar/documents/ESOMAR_Statutes.pdf).

Tabela 13 - Preocupações com neuromarketing

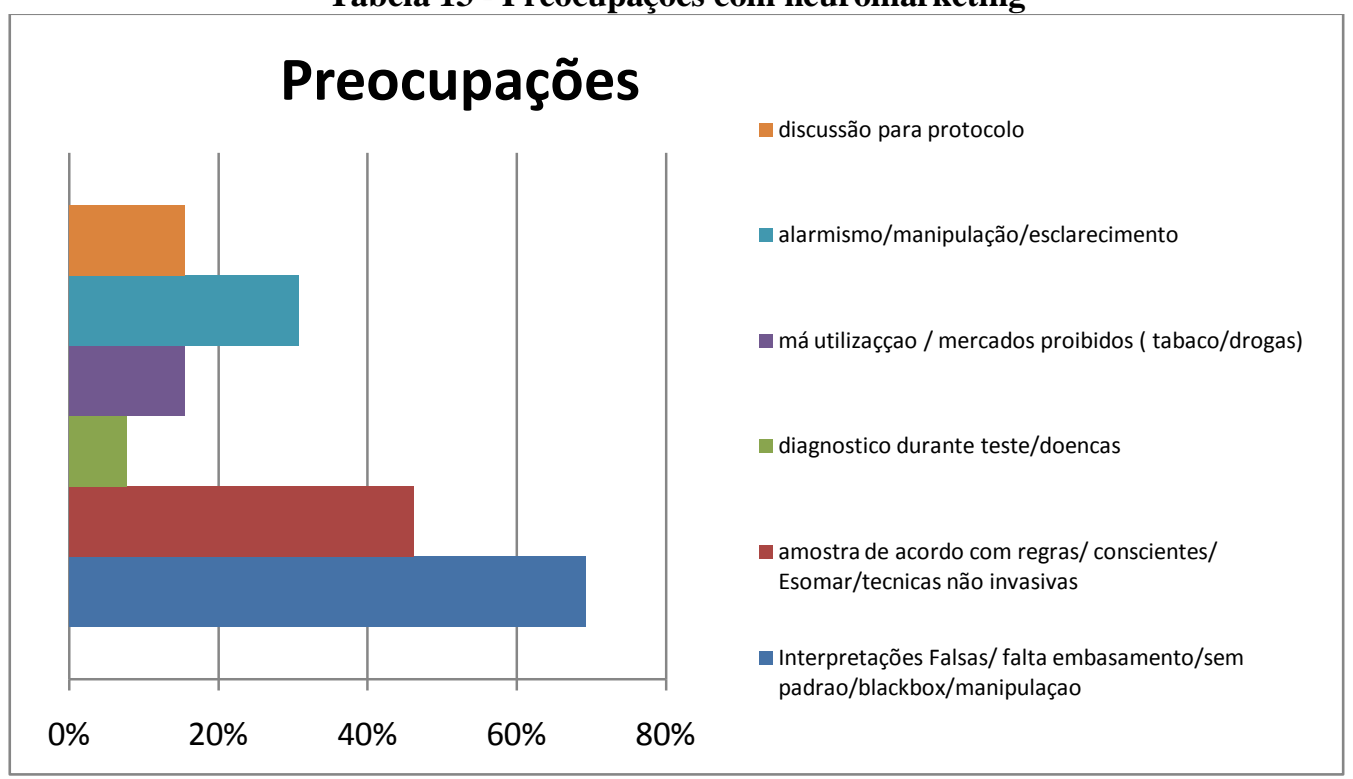

3.2.9

O Futuro do neuromarketing

Sobre o futuro do neuromarketing, cinco participantes acreditam que a combinação de métodos provenientes da contribuição entre diferentes áreas do saber é a forma de desenvolvimento do conhecimento. Essa é a resposta de quatro entre seis acadêmicos e dois instrumentistas. A segunda maior menção dos acadêmicos é a melhoria dos métodos de portabilidade - técnicas que possam contribuir na obtenção de dados durante a vivência cotidiana ou no desenvolvimento da atividade a ser estudada, sem ter que deslocar o indivíduo de seu habitat natural, e assim, ajudar na captação das reais respostas aos estímulos e contribuir com isso ao desenvolvimento da área de comportamento do consumidor. Os instrumentistas, por outro lado, apostam mais no desenvolvimento de métodos de combinação de dados capturados por diferentes técnicas, melhorando assim a sua interpretação e entendimento, o que parece ser uma aposta natural para esse grupo, pois os mesmos utilizam métodos diversos na captura de seus dados. Na sequência, a Tabela 14. 
Tabela 14 - O futuro do neuromarketing

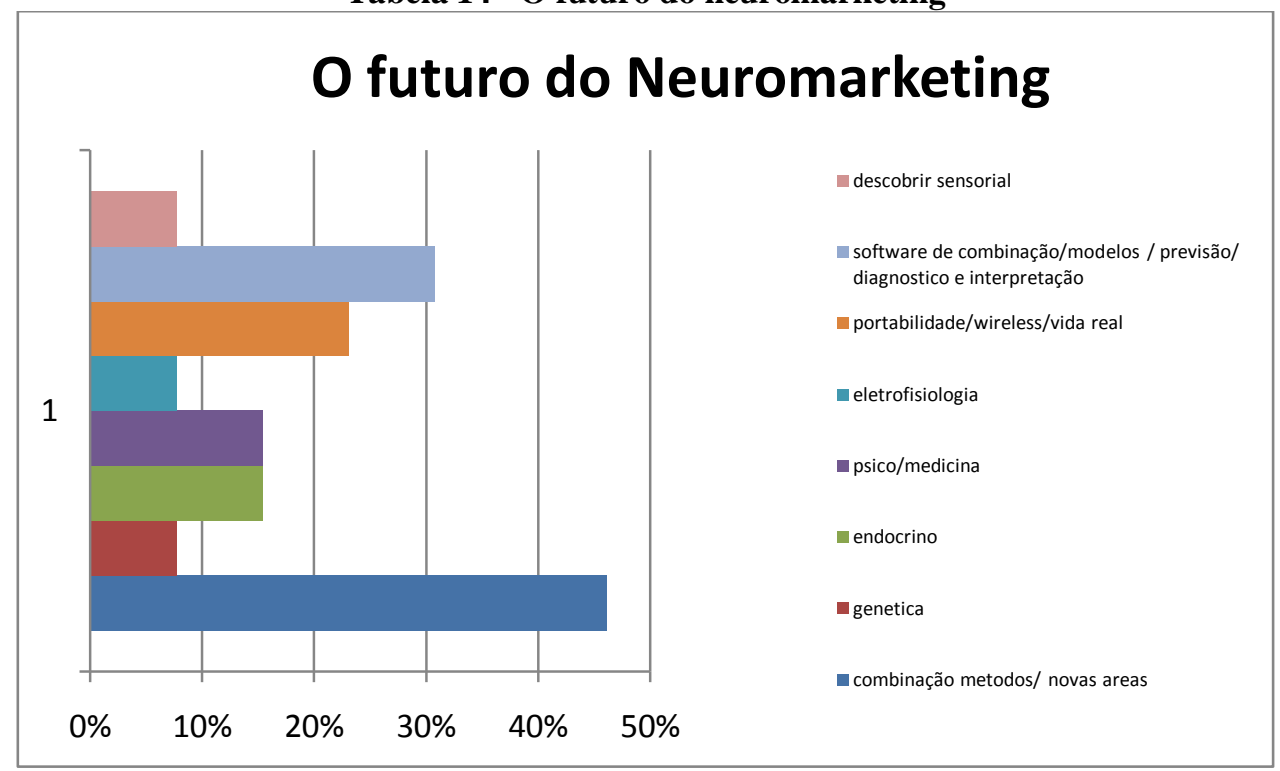

\subsubsection{0}

\section{Fontes declaradas de informações}

As fontes de onde provêm os conhecimentos pelos quais os entrevistados atualizam-se variam muito. De acordo com a Tabela 15 há seis menções de fontes oriundas de autores acadêmicos e artigos, dado número \#2 no gráfico, onde acadêmicos predominam em $90 \%$ da amostra; há cinco menções a autores e revistas não acadêmicas, refletidos no dado \#6, nesse caso amostra prevalecente de instrumentistas; há quatro menções a grupo de estudos multidisciplinar, no dado \#14, sendo prevalecente aqui o grupo de acadêmicos em sua totalidade; e por último destaque, vale mencionar a internet e suas buscas como outra fonte prevalecente entre instrumentistas com três menções, no item \#12.

Tabela 15: Fontes para o assunto neurociência e comportamento

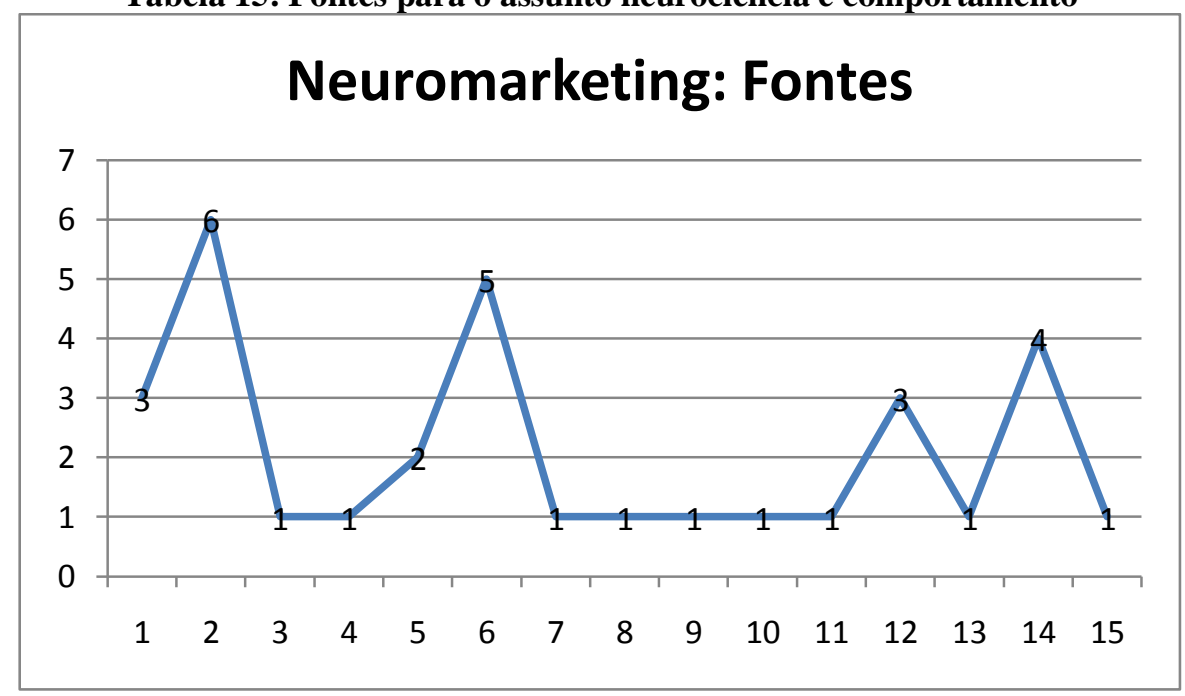


Vale destacar as fontes acadêmicas, oriundas de artigos presentes em revistas como a Web of Science, a Nature Science, a Behaviour Brain Science, a Journal of Science, a Review of Science e Pub Med.

Como ciências complementares ao marketing, além da neurociência, vale destacar: a física, a psicologia, a matemática, a engenharia. Como autores não acadêmicos com publicação foram citados Malcon Gladwell, Daniel Goleman e Rober Douley.

\subsection{Conclusões da pesquisa de Campo}

O tratamento dos dados permite fazer inferências e interpretações das entrevistas transcritas que foram preparadas para a análise de conteúdo e cujos trechos foram categorizados e codificados de acordo com as proposições, conforme exposto. Em seguida foi verificada a frequência das aparições, de acordo com os temas eleitos para análise, identificadas caso a caso em cada entrevista. Após esse procedimento foi realizada a análise temática - a frequência dos temas extraídos do conjunto de entrevistas.

Em relação às medições, foram realizadas contagens simples, analisando assim na amostra de 13 entrevistas o entendimento do todo. O Quadro11 é apresentado para maior visualização das conclusões. Nela estão contidas as 10 categorias e a maior menção do índice encontrado entre os respondentes. No entanto, seguem ainda outros detalhamentos:

A primeira categoria se refere ao envolvimento dos entrevistados com o estudo do comportamento do consumidor, proposta essa com a intenção de captar a riqueza da experiência do entrevistado com o tema, base do estudo da dissertação. Na categoria descrita o envolvimento deu-se de três maneiras, estas dependendo da formação base do entrevistado. Pode ter sido por meio de formação acadêmica, aprofundamento de sua profissão ou ainda curiosidade.

A segunda refere-se às razões que levaram ao estudo do comportamento e em decorrência da categoria anterior observou-se um interesse real pelo tema, seja como fonte adicional ou complementar à formação básica ou desenvolvimento profissional. 
A terceira categoria é onde se entende o envolvimento com a neurociência e também onde se encontra um interesse em buscar respostas para o entendimento do comportamento de alguma maneira, seja ele oriundo de medições biométricas ou ainda respostas cerebrais elétricas ou por localização do estímulo (imagem).

A quarta categoria descreve a definição do que é o neuromarketing pelo entendimento da amostra, e onde se conclui que a área ainda precisa de maiores desenvolvimentos para ser denominada uma ciência, uma vez que a maioria do painel, e principalmente os entrevistados acadêmicos, qualificam o termo como uma aplicação da neurociência em marketing. Nesse mesmo tema houve uma exploração das possíveis medições ou contribuições dessa aplicação em marketing, onde se concluiu que há contribuições no que se refere à medição de intensidade de reações, bem como sua polarização e ainda respostas atitudinais em relação aos estímulos. Tema que foi explorado em maior detalhamento na próxima categoria.

A quinta categoria qualifica as possibilidades de contribuição nas diferentes fases ou subprodutos de marketing. Uma lista de 12 itens foi gerada pelo painel. A saber: marca, ideia, protótipo, propaganda, impresso, musica/jingle, ponto de venda, loja virtual, sensorial/fragrância, preço, interatividade/navegabilidade e emoção. Dos itens mencionados, a maioria do painel, apesar da distribuição ter sido aleatória e múltipla, apresenta destaque para as fases de teste de propaganda e emoção, seguida de experiência virtual de ponto de venda e navegabilidade de site e teste de protótipo.

A sexta categoria elucida as técnicas utilizadas nas avaliações do neuromarketing, onde ficou evidente a utilização pelo grupo de medições biométricas, em sua maioria pelo eye tracking, e medições elétricas do cérebro realizadas pelo EEG. Estudos com realização de imagens cerebrais são utilizados em sua maioria pelos acadêmicos, uma vez que há limitações de investimento e também da forma de aplicação do estudo em consumidores.

Em uma sétima categoria verificou-se as vantagens e limitações dos estudos de neuromarketing e aqui se evidencia a possibilidade de diminuição das incertezas das respostas dadas pelos consumidores por meio das captações das intensidades de reação e localização das mesmas de forma inconsciente, como métodos complementares aos atuais declarados sejam por pesquisa qualitativa ou quantitativa. No entanto, há limitações, mencionando mais especificamente, a escassa publicação sobre o assunto e, portanto conhecimento compartilhado de protocolos de pesquisa e aprendizados bem como em sua aplicação 
laboratorial, o que faria que as simulações estudadas não representassem as situações presentes no cotidiano às quais os indivíduos são apresentados aos estímulos na vida real.

$\mathrm{Na}$ oitava categoria houve um foco sobre as preocupações trazidas pela amostra. A maior contribuição do grupo foi em elencar o problema de interpretação dos dados coletados por meio das técnicas da neurociência e suas interpretações individuais e em conjunto com outras técnicas. Aqui se menciona claramente a falta de protocolos e também de melhores práticas que possam ser compartilhadas e seguidas pelo mercado, bem como a ausência de métodos combinatórios que possam processar e, ao final, trazer maiores elucidações sobre os resultados dos estudos. Essa categoria é principalmente mencionada pelo público instrumentista, pois os mesmos não compartilham seus resultados de forma transparente com os colegas de outras empresas, uma vez que entendem que os dados são confidenciais e podem diminuir as vantagens competitivas com outras empresas, portanto entende-se que será difícil qualquer iniciativa em busca de protocolos que não seja de um órgão neutro, que utilize informações confidenciais e anônimas para formação de conhecimento, ou mesmo um órgão acadêmico que possa oferecer normas a serem seguidas.

Presente na nona categoria encontra-se o desenho futuro da área, pelo ponto de vista dos entrevistados. Para eles a combinação entre diferentes áreas do saber é algo presente em todas as declarações e o que se acredita trazer mais desenvolvimentos válidos e passíveis de compartilhamento.

Por último, o painel analisou as fontes de informações do grupo e conclui-se que ambos os segmentos, acadêmicos ou não, buscam informação em leituras. No entanto elas diferem em sua origem: acadêmicos, que utilizam artigos publicados em revistas de ciência em geral ou instrumentistas, que buscam em publicações genéricas, com autores de diversas áreas, fontes de informação e até mesmo a internet e suas informações.

O Quadro 11 apresenta resumo sobre as 10 categorias e seus principais destaques elencados por meio da análise de conteúdo de Bardin (2007): 
Quadro 11: Resumo das 10 categorias da análise de conteúdo

\begin{tabular}{ll} 
& Neuromarketing: Resumo 10 Categorias \\
1 & Envolvimento com Comportamento \\
2 & Razões para estudar \\
3 & Envolvimento com Neurosciencia e tecnicas familiares \\
4 & Definição Neuromarketing possiveis medidas \\
\hline 5 & Fases possiveis em Marketing \\
6 & Tecnicas utilizadas \\
7 & Vantagens e Limitaçoes \\
\hline 8 & Preocupações \\
\hline 9 & Futuro \\
\hline 10 & Fontes de Informarỗes \\
\hline
\end{tabular}

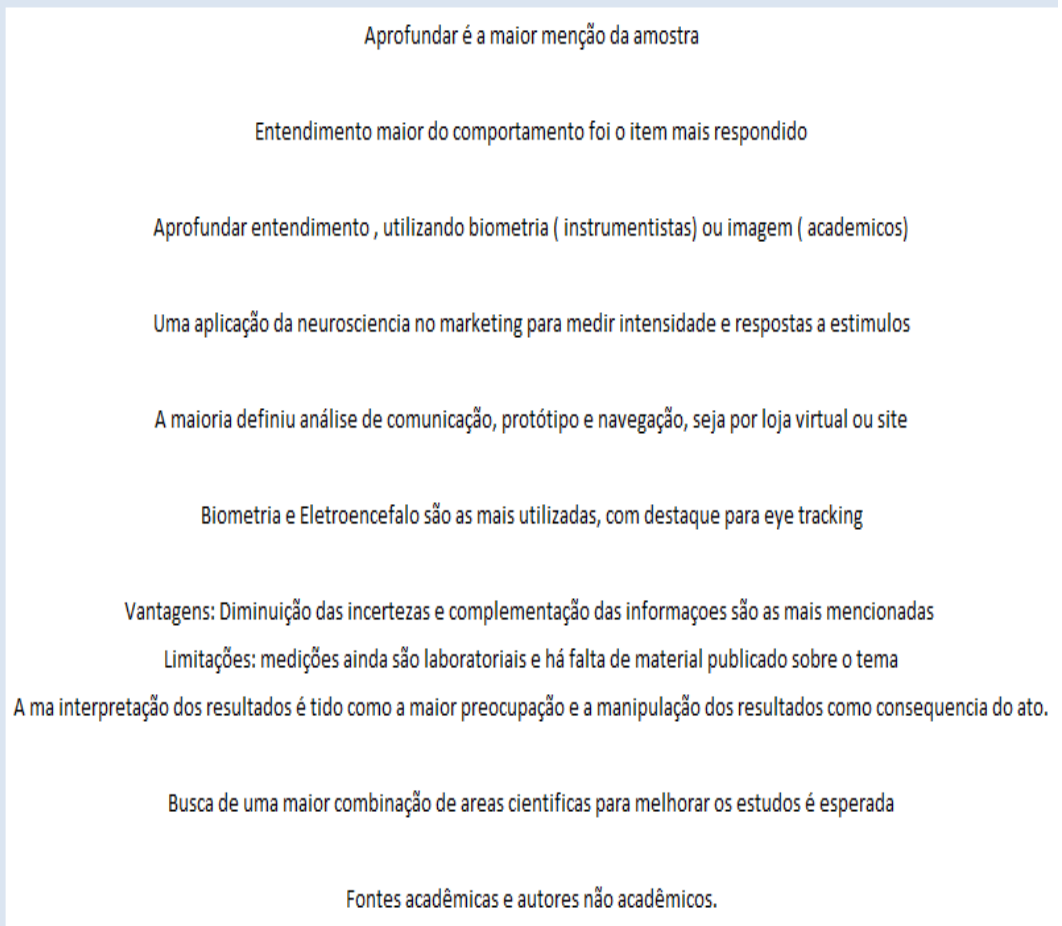

Havia sido mencionado, na primeira parte da dissertação, que até o momento existia uma diferença entre os artigos acadêmicos encontrados sobre neuromarketing versus o que se observa entre os estudos de comportamento do consumidor em prática no mercado e ainda há também diferenças entre os métodos utilizados comercialmente. Assim, existe uma diversidade de conceitos técnicos e aplicações encontradas na ciência e na prática.

$\mathrm{Na}$ busca por elucidar as diferentes contribuições de pesquisas de comportamento, suas principais características, dificuldades e ganhos em sua utilização durante o processo de marketing, buscou-se complementar os dados obtidos por investigação bibliográfica com uma pesquisa empírica onde se tenta evidenciar o assunto com uma perspectiva fresca, seja da ótica acadêmica sobre o assunto ou mesmo a utilização do mesmo em sua recente prática, em ofertas por empresas de pesquisa de mercado.

Após a finalização da análise da pesquisa empírica, a resposta aos objetivos propostos é oferecida com base não só na pesquisa em campo, mas também fruto da pesquisa bibliográfica sobre quais informações não declaradas do consumidor podem ser capturadas do 
cérebro e colaborar no processo do entendimento do consumidor com a utilização do neuromarketing.

O neuromarketing, conclui-se ao final, ou a aplicação da neurociência e suas técnicas em marketing, pode oferecer ganhos no entendimento das reações aos estímulos das marcas. Pela pesquisa empírica, evidencia-se que cada vez mais os estudos sobre as respostas inconscientes são ofertadas no mercado. No painel apresentado, empresas de pesquisa de mercado internacionais e nacionais já apresentam em seu portfólio de produtos regulares, e somente em estudos ad hoc, a utilização de biometria ou eletroencefalografia como técnicas de medições de produtos de marketing. Entre os acadêmicos também existem estudos com a utilização das técnicas já mencionadas como biometria e EEG, acrescidas de estudo de imagem - localização das áreas estimuladas do cérebro. Essas não são oferecidas ao mercado por meio de empresas de pesquisa por apresentarem altos custos ferramentais e também limitações de utilização em painéis de consumidores por serem ainda pouco adaptados às simulações cotidianas dos estímulos de marketing.

Até o momento, o que é um acordo comum no painel é a mensuração das intensidades das reações e sua polarização como forma de medição das reações aos estímulos de marketing. Esses podem ser ideias, protótipos, comunicações, navegações em ponto de venda simulados pelo computador ou mesmo navegações computacionais. Apesar da intenção de entender e identificar a correlação com o fato gerador, isso ainda é pouco explorado comercialmente e no mundo acadêmico a busca contínua pela origem da reação é perseguida.

A busca por protocolos e mais estudos é encorajada pelas pessoas envolvidas nos estudos da neurociência e a velocidade de seu desenvolvimento tem sido grande, porém ainda são poucas as publicações e trocas realizadas entre as diversas ciências e mesmo entre as empresas sobre melhores práticas ou até mesmo sobre como combinar resultados. A iniciativa pela The ARF, de validação e estabelecimento de procedimentos é entendida como válida, porém com certo ceticismo, uma vez que não inclui em seu painel representantes importantes de pesquisa de mercado e sua publicação até o momento é restrita aos seus colaboradores. Houve a citação da Esomar, como órgão passível de reunir, de forma anônima e isenta, um conglomerado de empresas que possam trabalhar e buscar protocolos. A área acadêmica, no entanto, acredita que trabalhos que conjuguem diversas áreas do saber, a citar: psicologia, matemática, neurociencia, linguística, estatística e outras, podem ajudar a complementar e aumentar o entendimento das reações e suas causas. 
Após as conclusões finais da pesquisa empírica oferece-se um quadro comparativo com os resultados confrontados com os obtidos na conclusões da fase de pesquisa bibliográfica . Com isso, no Quadro 12 obtêm-se um resumo validado do painel de entrevistados em sua composição dupla, com a presença de acadêmicos e instrumentistas.

Pretendeu-se estudar quais seriam as informações não declaradas do consumidor que podem ser capturadas do cérebro para corroborar no processo do entendimento de seu comportamento de consumo. Portanto, claramente são identificadas áreas de contribuição e recomendadas formas de utilização, bem como as melhores fases de aplicação em marketing, como resumo de maneiras de adição de conhecimento ao comportamento em uma função colaborativa a outras metodologias.

Quadro 12 - Resumo das contribuições do neuromarketing

\begin{tabular}{|c|c|c|}
\hline NEUROMARKETING & LEVANTAMENTO BIBLIOGRÁFICO & PESQUISADE CAMPO \\
\hline 0 que é medido & $\begin{array}{l}\text { Investigação da cognição e reações } \\
\text { biométricas }\end{array}$ & $\begin{array}{l}\text { Uma aplicação da neurociência no marketing } \\
\text { para medir intensidade e respostas a estímulos }\end{array}$ \\
\hline Tipo de processo de resposta & $\begin{array}{l}\text { Dados quantitativos. Reações cerebrais( } \\
\text { neuroimagem) acrescida de mediçőes } \\
\text { biométricas como reaçőes visuais, de pele, } \\
\text { muscular ou alteração batimento cardíaco) }\end{array}$ & $\begin{array}{l}\text { Dados quantitativos de intensidade e respostas } \\
\text { a estímulos de reaçőes cerebrais e mediçőes } \\
\text { biométricas. Mais freqüentes mediçőes } \\
\text { elétricas do escalpo e respostas visuais da } \\
\text { direção do olhar. }\end{array}$ \\
\hline Uso típico & $\begin{array}{l}\text { Avaliar reaçőes aosestímulos do } \\
\text { produto/serviço marca nas diversas fases do } \\
\text { desenvolvimento }\end{array}$ & $\begin{array}{l}\text { A maioria definiu análise de comunicação, } \\
\text { protótipo e navegaçăo, seja por loja virtual ou } \\
\text { site }\end{array}$ \\
\hline Custose Riscos & Alto custo e alto risco de interpretação e erro. & $\begin{array}{l}\text { Com utilização da biometria e } E \mathrm{E} G \text { os custos } \\
\text { não são altos. Limitações : mediçőes ainda são } \\
\text { laboratoriais e há falta de material publicado } \\
\text { sobre o tema, além da má interpretação dos } \\
\text { resultados a manipulação dos mesmos como } \\
\text { consequêencia. }\end{array}$ \\
\hline Habilidade técnica necessária & $\begin{array}{l}\text { Altamente especializado : neurociênciae } \\
\text { psicologia cognitiva e estatística para } \\
\text { combinação de dados entre diferentes fontes } \\
\text { de informação. }\end{array}$ & $\begin{array}{l}\text { Altamente especializada e composta por várias } \\
\text { especialidades científicas. Necessidade } \\
\text { mencionada de maior possibilidade de } \\
\text { métodos combinatórios entre mediçőes. }\end{array}$ \\
\hline Fase de Marketing & $\begin{array}{l}\text { Todas as fases. Da elaboração inicial de } \\
\text { protótipos à avaliação depois da compra. }\end{array}$ & $\begin{array}{l}\text { A maioria definiu análise de comunicação, } \\
\text { protótipo e navegaçăo, seja por loja virtual ou } \\
\text { site }\end{array}$ \\
\hline Fase do Processo de Decisão & Input e Processo decisório & $\begin{array}{l}\text { Medir intensidade e respostas àsidéiase } \\
\text { protótipos na fase de Input também no } \\
\text { processo decisório, medindo resposta aos } \\
\text { estímulos provocados pela marca. Citaçőes } \\
\text { mais freqüentes: propaganda, experiência de } \\
\text { navegação e ponto de venda. }\end{array}$ \\
\hline
\end{tabular}




\section{CONSIDERAÇÕES FINAIS, LIMITAÇÕES E RECOMENDAÇÕES}

O objetivo da dissertação foi avaliar se o neuromarketing pode ser uma nova área de colaboração ao entendimento do consumidor, capaz de obter as informações não declaradas pelo mesmo que podem ser capturadas do cérebro para corroborar no processo do entendimento de seu comportamento de consumo, validando-o como uma nova área de colaboração.

O resgate da literatura referente aos estudos oferecidos para entender o comportamento do consumidor em seus diferentes estágios permitiu verificar que atualmente o modelo oferecido por Ariely e Bern (2010) é incompleto, ou seja, entre as metodologias analisadas pelos autores para obtenção de conhecimento sobre o comportamento do consumidor ainda há lacunas no que se refere ao entendimento do processo psicológico e também do output - depois de haver a experiência com o produto ou serviço, falta entender o impacto como os descritos no modelo de Schiffmann e Kanuk (1997) no mapeamento do processo decisório. Portanto, continua sendo importante a exploração de outras metodologias que possam agregar conhecimento ao processo.

A revisão da literatura, em busca do preenchimento das lacunas encontradas nas pesquisas de investigação de comportamento do consumidor, obteve a exploração dos benefícios oferecidos por novas metodologias, examinadas inicialmente neste estudo, como semiótica e sua contribuição para a comunicação, a ciência cognitiva e sua investigação dos tempos de reação e finalmente a proposta oferecida pelo neuromarketing.

No entanto, entendeu-se que, para buscar um assunto novo como o neuromarketing, era necessário averiguar desde o básico, como o conceito aceito pelos acadêmicos e o utilizado pelos instrumentistas. Avaliar seu entendimento, suas contribuições e limitações. Explorar a existência de práticas, suas semelhanças e diferenças entre a academia, isto é, o público acadêmico e sua exploração do inconsciente do consumidor e os instrumentistas, suas metodologias e aplicações. Saber ainda quais as medições inconscientes que poderiam ser identificadas e para quais estímulos de marketing eram indicadas, bem como em quais fases essa aplicação é recomendada para teste. 
Inquietudes como as aqui elencadas demonstraram ser necessária uma pesquisa empírica com a presença do mundo acadêmico e também de empresas de pesquisa de mercado. Essa foi formatada para contribuir com dados mais recentes, práticos ou teóricos, com diferentes pontos de vista, com uma parte mais acadêmica e outra mais empírica, oriundas de grandes centros de exploração sobre o tema presentes no mundo todo. Para isso, a pesquisa da amostra escolhida foi bastante cuidadosa e difícil, pois parte dos respondentes, e pessoas envolvidas recentemente em estudos de neuromarketing vivem no exterior, prioritariamente nos Estados Unidos e Europa, e estão ligados a grandes centros universitários ou grandes empresas de pesquisa de mercado. Assim, dificuldades como idioma, localização, fuso horário, desconhecimento do entrevistador e outros tiveram que ser transpostos para a realização da pesquisa empírica. No entanto, pela escolha de um painel de entrevistados que não supre, ou cobre toda a população potencial sobre o tema, buscou-se enriquecer seu conteúdo na eleição de pessoas relevantes, atuantes em várias posições geográficas, com investigações ativas em recentes pesquisas e práticas sobre o tema.

O estudo proposto, com a abordagem feita em profundidade com especialistas de diversas áreas, enriquece o tema neuromarketing ofertando diferentes ângulos sobre o tema e uma complementação às técnicas de marketing oferecidas por Ariely e Berns (2010), além de evidenciar a necessidade de maior entendimento dos processos de decisão, aqui analisados por Schiffman e Kanuk (1997). O resultado oferece uma visão abrangente, capaz de evidenciar a necessidade de uma continuidade na investigação, uma vez que o assunto envolve áreas ainda muito recentemente exploradas pela ciência em conhecimentos básicos do funcionamento cerebral e suas possíveis correlações com o comportamento humano.

Entende-se que o conteúdo trazido por este estudo, por ser inovador e atual, além de oferecer maiores fontes de explicação para o cenário de mercado contemporâneo, oferece um material empírico que poderá contribuir e elucidar a questão problema oferecendo novas hipóteses para que futuramente possam ser aprofundadas em novas investigações, não só para áreas de marketing e comunicação, mas também para área de investigação comportamental de uma forma geral.

Dentre as limitações encontradas no estudo a primeira se relaciona ao painel entrevistado. Esse foi escolhido por conveniência, a partir de investigação sobre os assuntos relevantes sobre o tema recentemente publicados na academia ou por pesquisas de mercado 
recentemente publicadas em revistas e jornais de mercado. Esse critério apresenta claramente as limitações da pesquisa. No intuito de ressalvar as possíveis imprecisões e estimular o desenvolvimento de futuros trabalhos relacionados ao tema, é importante atentar para a abrangência dos resultados. Acredita-se que a utilização de uma amostra de conveniência e o grau de inovação e complexidade do assunto dificulta que os resultados possam ser extrapolados das respostas individuais à totalidade dos entrevistados. Entrevistas posteriores, bem como novos estudos poderão enriquecer o assunto e talvez possam, no futuro, serem passíveis de extrapolação.

Além disso, para Ruiz (2004) existe uma série de desvantagens possíveis em uma pesquisa qualitativa a serem gerenciadas de acordo com o autor. A pesquisa qualitativa leva à necessidade de decodificação subjetiva por usar a linguagem na expressão das ideias. Tal fato acarreta a possibilidade de haver vieses na interpretação dos resultados, sendo essa uma das grandes críticas por parte dos defensores do método quantitativo tradicional. A falta de delimitação clara do tema a ser estudado leva a pesquisa qualitativa a ser usada mais em etapas exploratórias e menos em fases mais adiantadas da pesquisa, em que normalmente já se tem uma definição do assunto específico. A coleta e análise de dados são usualmente mais trabalhosas, e os métodos e convenções são geralmente menos estruturados que os da pesquisa quantitativa. Ela permite maior generalização dos resultados, o que não se pode normalmente fazer para a abordagem qualitativa, que utiliza mais a indução como meio de generalização.

Outra limitação encontrada foi relacionada à teoria sobre o assunto, suas técnicas, estudos existentes, uma vez que são muito recentes e também são provenientes de combinação entre áreas. Assim, os dados, quando disponíveis, podem estar em áreas distantes e distintas como psicologia, medicina, matemática, estatística, psiquiatria, e uma varredura completa torna-se muito complexa para realização na presente dissertação.

Além da limitação teórica, há falta de protocolos e validações coletivas sobre a teoria do neuromarketing, claramente mencionado na iniciativa do projeto colaborativo em realização pela Advertising Research Foundation, The ARF. Como já anteriormente descrita, essa iniciativa está buscando o estabelecimento de procedimentos comuns e melhores práticas com um envolvimento e colaboração de equipe múltipla, com presença de empresa, institutos de pesquisa e cientistas em cooperação para o estudo do comportamento na aplicação da 
neurociência. No entanto, por ser composta por um painel ainda limitado a seus contribuintes, e não pela totalidade de empresas do mercado, ainda não é conclusivo e necessita de maior conhecimento e publicação para sua validação entre seus pares.

Como sugestão, seria importante a manutenção de contínuas investigações que validem e formem um arcabouço de conhecimento de investigações de comportamento, mais explicitamente as respostas aos estímulos das seguintes fases em marketing: análise de protótipos, comunicação, análise de navegação de sites e também maiores simuladores de ambientes virtuais. Outras investigações que validem os protótipos de EEG e testes biométricos portáteis também seriam importantes para analisar se os testes realizados em laboratórios quando transportados para um ambiente real conseguem evidenciar os resultados obtidos. A introdução de programas que consigam combinar dados de diversas fontes de investigação também seriam de muita valia, podendo assim oferecer contribuições valiosas tanto para investigações já realizadas como para as futuras.

Os homens devem saber que a partir de nada mais do que o cérebro surgem as alegrias, prazeres e risos, tristezas, dores, desânimo e lamentações. E por isso, de uma maneira especial, adquirimos sabedoria e conhecimento, e a capacidade de ver e ouvir e saber o que sobra e o que falta, o que é mau e que é bom, o que é doce e o que é desagradável ... E pelo mesmo órgão nos tornamos loucos e delirantes, e medos e terrores nos assaltam ... Todas essas coisas nós sofremos quando o cérebro não é saudável .... Por causa de tudo isso é que eu sou da opinião que o cérebro exerce o maior poder sobre o homem. HIPPOCRATES, On the Sacred Disease ( Fourth Century B.C.) ${ }^{1}$.

\footnotetext{
1 Tradução livre da autora - "Men ought to know that from nothing else but the brain come joys, delights, laughter and sports, and sorrows, griefs, despondency, and lamentations. And by this, in an especial manner, we acquire wisdom and knowledge, and see and hear and know what are foul and what are fair, what are bad and what are good, what are sweet and what are unsavory..... And by the same organ we become mad and delirious, and fears and terrors assail us.... All these things we endure from the brain when it is not healthy... In these ways I am of the opinion that the brain exercises the greatest power in the man" - Hippocrates, On the Sacred disease ( Fourth century B.C.). (BEAR, Mark F et al, 2007, p.4).
} 


\section{REFERÊNCIAS}

ADVERTISING RESEARCH FOUNDATION - The ARF. Neurostandards Collaboration Project. 2011. Disponível em: http://www.thearf.org/assets/neurostandards-collaboration. Acesso em: 08/2011.

AMERICAN MARKETING ASSOCIATION - AMA. Disponível em: www.marketingpower.com/Pages/default.aspx. Acesso em: 05/2009.

ANDRADE, Josmar. A imagem como elemento da retórica do marketing. Um estudo da evolução dos anúncios veiculados em revista. São Paulo, 2009. Tese (Doutorado em Administração) - Programa de Pós-Graduação em Administração, Departamento de Administração, Faculdade de Economia, Administração e Contabilidade da Universidade de São Paulo.

ARIELY, Dan; BERNS, Gregory S. Neuromarketing: the hope and hype of neuroimaging in business. Nature reviews / Neuroscience. v.11, abril 2010.

ASHCRAFT, Mark H. Cognition. 3 ed. New Jersey: Prentice-Hall, 2002.

ASTOLFI, Laura et al. Basis for Brain Responses to TV Commercials: A High-Resolution EEG Study. IEEE Transactions on Neural Systems and Rehabilitation Engineering. v. 16, n 6, 2008.

BAIN, Robert. 2010 and all that. Disponível em: www.research-live.com/magazine/2010and-all-that/4004287.article. Acesso: em 21/08/2011

BARDIN, Laurence. Análise de conteúdo. 4 ed. Lisboa: Edições 70, 2007.

BARRETO, Armando; ZHAI, Jing. Physiological Instrumentation for Real-time Monitoring of Affective State of Computer Users. WSEAS Transactions on Circuits and Systems, v. 3, 2003.

BARRETO, Armando et al. Non-intrusive Physiological Monitoring for Automated Stress Detection in Humnan-Compuyter interaction. Human Computer Interaction, Lecture Notes in Computer Science, v. 4796, Springer-Verlag Berlin Heidelberg, 2007.

BATISTA, Leandro Leonardo et al. Aspectos Cognitivos da percepção da propaganda. Ciências \& Cognição, v. 13, 2008.

BEAR, Mark F et al. Neuroscience Exploring the Brain. 3 ed. Philadelphia: Lippincott Williams \& Wilkins, 2007. 
BELCH, George E; BELCH, Michael A. Propaganda e Promoção. 7 ed. São Paulo: McGraw-Hill, 2008.

BERKA, Chris et al. (2005). Evaluation of an EEG-Workload Model in an Aegis Simulation Environment. Proceedings of SPIE Defense and Security Symposium, Biomonitoring for Physiological and Cognitive Performance during Military Operations, Orlando, FL, SPIE: The International Society for Optical Engineering. 2005.

BIOMETRIA. Disponível em: http://misnt.indstate.edu/harper/Biometrics/Biometrics.htm http://www.economist.com/node/360238?Story_ID=360238. Acesso em: 08/2011.

BLACKWELL, Roger D et al. Comportamento do Consumidor. 9 ed. São Paulo: Pioneira Thompson Learning, 2005.

BLAKESLEE, Sandra. If you have a "Buy Button" in Your Brain, What pushes it? The New York Times, October 19, 2004. Disponível em: http://www.uky.edu/AS/PoliSci/Peffley/pdf/Blakeslee\%20NYT\%2004\%20_If\%20You\%20H ave $\% 20$ a $\% 20$ 'Buy\%20Button'\%20in\%20Your\%20Brain,\%20What\%20Pushes\%20It.pdf. Acesso em: 08/2011.

BRAEUTIGAM, Sven. et al. Magentoencephalographic signals identify stages in real-life decision processes. Neural Plasticity, n. 8, 2001.

The distributed neuronal systems supporting choice-making in real-life situations: differences between men and women when choosing groceries detected using magneto encephalography. Neurocience, n. 20, 2004.

BRUNEL, Frédéric F et al. Is the Implicit Association Test a Valid and Valuable Measure of Implicit Consumer Social Cognition? Journal of Consumer Psychology, n. 14(4), 2003.

CAMERON, Deborah. Moving to the dark side of the screen. Disponível em: http://www.smh.com.au/news/technology/moving-to-the-dark-side-of-thescreen/2006/05/12/1146940739294.html?page=fullpage\#contentSwap2 13/05/2006. Acesso em: $08 / 2011$.

CARLSON, Kurt A et al. Leader-Driven Primacy: Using attribute order to affect consumer choice. Journal of Consumer Research, v. 32, n. 4, 2006.

CASTELLS, Manuel. Communication power. 1 ed. Oxford University Press, UK, 2009.

CAVUOTO, James. Neurosensing the Consumer. Disponível em: www.neurotechreports.com/pages/publishersletterJan11.html em 02/02/11 Acesso em: 08/2011.

CHEESMAN, Jim; MERIKLE, Philip M. Priming with and without awareness. Percept Psychophysics, v. 36, 1984. 
CHURCHILL JR. Gilbert A. Marketing Research: methodological foundations. 3 ed. Fort Worth, TX: The Dryden Press, 1996.

CIALDINI, Robert. B. Influence. The psychology of persuasion. 3 ed. Collins, NY: Harper Collins, 2007.

COMPAGNO, Carolina F L. Análise Semiótica e Gestão de marcas - Um estudo exploratório. São Paulo, 2009. Dissertação (Mestrado em Administração) - Programa de PósGraduação em Administração, Departamento de Administração, Faculdade de Economia, Administração e Contabilidade da Universidade de São Paulo.

CRESCITELLI, Edson. Crise de credibilidade da propaganda: considerações sobre seu impacto na eficácia da mensagem. Revista FACOM - Faculdade de Comunicação da FAAP. São Paulo, $2^{\circ}$ sem, 2004.

CUNNINGHAM, William A. et al. Separable Neural Components in the processing of Black and White Faces. Psychological Science, v. 15, n. 12, 2004.

DEELY, John. Semiótica Básica. 1 ed. São Paulo: Ática, 1990.

EAGLY, Alice. H.; CHAIKEN, Shelly. The Psychology of Attitudes. New York: Harcourt Brace Jovanovich College Publishers, 1993.

ELETROENCEFALOGRAMA. Disponível em:

http://www.lsa.umich.edu/psych/danielweissmanlab/whatiseeg.htm. Acesso em: 08/2011.

ERK, Suzanne et al. Cultural objects modulate reward circuitry. Neuroreport, n. 44, 2002.

FARREL, Paul. B. The millionaire Code: 16 Path to walth building. John Wiley \& Sons: New Jersey, 2003.

FISHER, Carl E et al. Defining Neuromarketing: Practices and Professional Challenges. Harvard Review Psychiatry Perspectives, 2010.

GREENWALD, Anthony G et al. Measuring individual differences in social cognition: The implicit Association test. Journal of Personallity and Social Psychology, v. 74, 1998. Disponível em: www.yale.edu.implicit. Acesso em: 08/2011.

HOWARD, John A. Consumer Behavior in Marketing Strategy. Englewood Cliffs, NJ: Prentice Hall College Div, 1989.

HOWARD, John A; JAGDISH N Sheth. The Theory of Consumer Behavior. New York: Wiley, 1969. 
HUBERT, Mirja.; KENNING, Peter. IA current overview of consumer neuroscience. Journal of Consumer Behavior, n. 7, 2008.

JACOB, Robert J.K; KARN, Keith S. Eye tracking in Human-Computer Interaction and Usability Research: Ready to deliver the promises. The Mind's Eye: Cognitive and Applied Aspects of Eye Movement Research. Hyona, Radach \& Deubel (eds.) Oxford: England, by Elsevier Science $\quad$ BV, 2003. Disponível em: www.sciencemag.org/content/333/6044/838.abstract http://www.cs.tufts.edu/ jacob/papers/bit.pdf. Acesso em: 20.ago.2011.

JAIN, Anil K et al. Biometrics Personal Identification in Networked society. Kluwer Academic Publishers: Massachussets, 2002

JAIN, Anil K. et al. Handbook of biometrics. New York: Springer, 2010.

KANDELL, Erik R. et al. Principles of Neural Science. 4 ed. Mc Graw: Hill, 2000.

KAPLAN, Jonas $\mathrm{T}$ et al. US versus them: political attitudes and party affiliation influence neural response to faces of presidential candidates. Neuropsychologia, n. 45, 2007.

KATZ, Daniel. The Functional Approach to the Study of Attitudes. Public Opinion Quarterly, n. 24, 1960.

KAWASHIMA, Ryuta. Computer games stunt teen brains: Hi-tech maps of the mind show that computer games are damaging brain development and could lead to children being unable to control violent behaviour. Tracy McVeigh, education editor. The Observer, Sunday 19 August 2001. Disponível em: http://www.guardian.co.uk/world/2001/aug/19/games.schools Acesso em: ago.2011.

KOTLER, Philip; ARMSTRONG, Gery. Princípios de Marketing. 12 ed. São Paulo: Prentice Hall, 2008.

KOTLER, Philip; KELLER, Kevin L. Administração de Marketing. 12 ed. São Paulo: Prentice Hall, 2005.

KRINGELBACH, Morten L; BERRIDGEE, Kent C. Towards a functional neuroanatomy of pleasure and happiness. Trends in Cognitive Sciences, v. 13, n. 11, 2009.

LAKATOS, Eva; MARCONI, Marina. Metodologia Científica. São Paulo: Atlas, 1991.

LAKOFF, George. The Political Mind: Why you can't Understand 21 st-century Politics with an 18-century Brain. New York: Viking, 2008. 
LAWES, Rachel. Demystifying Semiotics: Some Key Questions Answered. International Journal of Market Research, v. 44, n. 3, 2003.

LEE, Nick. et al. What is neuromarketing? A discussion and agenda for future research. International Journal of Psychophysiology, v. 63, 2007.

LEHRER, Jonah. The Retoric of Neuroscience. Disponível em: www.wired.com/wiredscience/2011/08/the-retoric-of-neuroscience Acesso em: 20/08/2011.

LENT, Robert. Cem Bilhões de neurônios? Conceitos Fundamentais da Neurociência. 12 ed. São Paulo: Editora Atheneu, 2010.

LEWIS, David. Pioneering studies. Measuring EEG responses. Disponível em http://www.drdavidlewis.co.uk/neuromarketing.html. Acesso em: ago.2011

LINDSTROM, Martin. Buyology. Truth and lies about why we buy. New York: Doubleday, 2008.

LINSTONE, Harold A.; TUROFF, Murray. The Delphi method: techniques and applications. Massachusetts: Addison-Wesley, 1975.

LIPOVETSKY, Gilles. La sociedad de la decepción. Editorial Anagrama: Barcelona, 2008.

McCLURE, Samuel M et al. Neural correlates of behavioral reference for culturally familiar drinks. Neuron, n. 44, 2004.

MALHOTRA, Naresh. K. Pesquisa de marketing: Foco na decisão. 3 ed. São Paulo: Pearson Prentice Hall, 2011.

MANDEL, Naomi; JOHNSON, Erik J. When Web pages influence choice: Effects of visual primes on experts and novices. Journal of Consumer Research, v. 29, 2002.

MATTAR, Fauze. N. Pesquisa de marketing: edição compacta. 6 ed. São Paulo: Atlas, 2011.

MORAES, Roque. Análise de conteúdo. Revista Educação, Porto Alegre. v. 22, n. 37, 1999.

NATIONAL INSTITUTE OF MENTAL HEALTH. fMRI e MEG .Set/ 11 Disponível em: http://infocenter.nimh.nih.gov/il/public_il/image_details.cfm?id=80

Neurofocus Case studies: http://www.neurofocus.com/pdfs. Acesso em: ago.2011.

NELSON, Jeniffer. Cérebro Dissecado. Revista Men’s Health. Editora Abril, n. 7, mai 2009. 
NIEMEYER, Kyle. Temporary tattoos fitted with electronics make flexible, ultrathin sensors. Disponível em: http://Arstechnica.com/science/news/2011/08/temporary-tattoo-electronicsflexible-ultrathin e www.sciencemag.org/content/333/6044/838.abstract. Acesso em: 20/08/2011.

OLIVEIRA, Erika C. Comportamento do Consumidor Processo de Decisão de Compra de Livros pela Internet. Universidade de São Paulo. São Paulo, 2007.

PENENBERG, Adam L. NeuroFocus Uses Neuromarketing to hack your Brain. Disponível em: www.fastcompany.com/magazine/158/neuromarketing-intel-paypal Acesso em: 08/2011.

PESSOA, Luiz. How do emotion and motivation direct executive control? Trends in Cognitive Sciences, v. 13, n. 4, 2009.

PHELPS, Elizabeth A et al. Performance on Indirect Measures of Race evaluation Predicts Amygdala activation. Journal of Cognitive Neuroscience, v. 12:5, 2000.

PLASSMANN, Hilke et al. Marketing actions can modulate neural representations of experienced pleasantness. Proc. Natl Acad.Sci. PNAS, USA, v. 105, 2008.

POON, Derek T. Y.; PRENDERGAST, Gerard. A new framework for evaluating sponsorship opportunities. International Journal of Advertising, v. 25(4), 2006.

PRADEEP, Anantha K. The iceberg atop your shoulders: neuromarketing in the global economy. The European Business review, march-April 2011. Disponível em: www.europeanbusinessreview.com. Acesso em: 08/2011.

ROBERTSON, Thomas S et al. Consumer Behavior. New York: Scott Foremann and Company, 1984.

ROSE, Gillian. Visual Methodologies. 2 ed. London: Sage, 2007.

ROSSITER, John $\mathrm{R}$ et al. Brain-imaging detectionof visual scene encoding in long-term memory for TV commercials. Journal of Advertising Research, v. 41, 2001.

RUIZ, Fernando M. Pesquisa Qualitativa e Pesquisa Quantitativa: Complementaridade cada vez mais enriquecedora. Administração de Empresas em Revista, Curitiba, n. 3, 2004.

SANTAELlA, Lucia. A Teoria Geral dos Signos. São Paulo: Thomson, 2000.

. Semiótica Aplicada. São Paulo: Thompson, 2002.

SANTAELlA, Lucia; NOTH, Winfried. Imagem, Cognição Semiótica Mídia. São Paulo: Iluminuras, 2005. 
SCHIFFMAN, Leon G.; KANUK, Leslie L. Comportamento do Consumidor. Rio de Janeiro: LTC - Livros Técnicos e Científicos Editora, 2000.

SELLTIZ, Claire et al. Métodos de Pesquisa nas relações sociais. 1 Ed. São Paulo. EPU, 1960.

SENIOR, Carl. Beauty in the brain of the beholder. Neuron, v. 38, 2003.

SINGER, Natasha. Making ads that whisper to the brain. The New York Times, november, 13, 2010. Disponível em: www.nytimes.com Acesso em: 08/2011.

SPIERS, Hugo J; MAGUIRE, Eleanor A. Spontaneous mentalizing during an interactive real world task: an fMRI study. Neuropsychologia, v. 44, 2006.

STERNBERG, Robert J. Psicologia Cognitiva. Artmed: Porto Alegre, 2000.

SOLOMON, Michael R. O comportamento do consumidor: comprando, possuindo e sendo. Porto Alegre: Bookman, 2002.

THE LANCET NEUROLOGY MAGAZINE, v. 3, 02/2004. Disponível em: http://www.neurology.thelancet.com/neuromarketing/beyond/branding e

http://www.thelancet.com/journals/laneur/article/PIIS1474-4422(03)00643-4/fulltext. Acesso em: 08/2011.

THORNTON, Davi J. Brain Culture: Neuroscience and Popular Media. Rutgers University Press. New Brunswick: New Jersey, 2011 Disponível em: http://www.wired.com/wiredscience/2011/08/the-rhetoric-of-neuroscience/ Acesso em: 08/2011.

WALTER, Henrik. et al. Motivating forces of human actions Neuroimaging reward and social interaction. Brain Research Bulletin, v. 67, 2005.

WICKENS, Christopher. Multiple resources and performance prediction. Theor Issues In Ergon. SCI, v. 3, n. 2, 2002.

WINKIELMAN, Piotr.; BERRIDGE, Kent. Irrational wanting and subrational liking: How rudimentar motivational and affective processes shape preferences and choices. Political Psychology, v. 24, n. 4, 2003.

XEREZ, Eduardo. Neurociência: uma nova modalidade de pesquisa em comportamento de consumo. Faculdade de Administração, PUC/Rio, 2005.

YIN, Robert K. Estudo de Caso: Planejamento e Métodos. 3 ed. São Paulo: Bookman, 2005. 
YOUNG, Chuck. Brain Waves, picture sorts, and branding moments. Journal of Advertising Research. v. 42, 2002.

ZALTMAN, Gerald; KOSSLYN, Stephen M. Neuroimaging as a marketing tool. US Patent $\mathbf{6 , 0 9 9 , 3 1 9 . ~ A u g u s t , ~ 8 t h ~} 2000$. 


\section{APÊNDICES}

APÊNDICE 1 - PAINEL DE ENTREVISTADOS

APENDICE 2 - ENVOLVIMENTO COM COMPORTAMENTO

APÊNDICE 3 - NEUROMARKETING: DEFINIÇÃO

APÊNDICE 4 - NEUROMARKETING: O QUE DÁ PARA MEDIR E EXEMPLOS

APÊNDICE 5 - NEUROMARKETING: O QUE SE PEDE EM MARKETING

APÊNDICE 6 - NEUROMARKETING: TÉCNICAS QUE UTILIZA

APÊNDICE 7 - NEUROMARKETING: VANTAGENS

APÊNDICE 8 - NEUROMARKETING: LIMITAÇÕES

APÊNDICE 9 - NEUROMARKETING: PREOCUPAÇÕES

APÊNDICE 10 - NEUROMARKETING: O FUTURO

APÊNDICE 11 - NEUROMARKETING: FONTES

APÊNDICE 12 - NEUROMARKETING: RESUMO 10 CATEGORIAS 


\section{APÊNDICE 1}

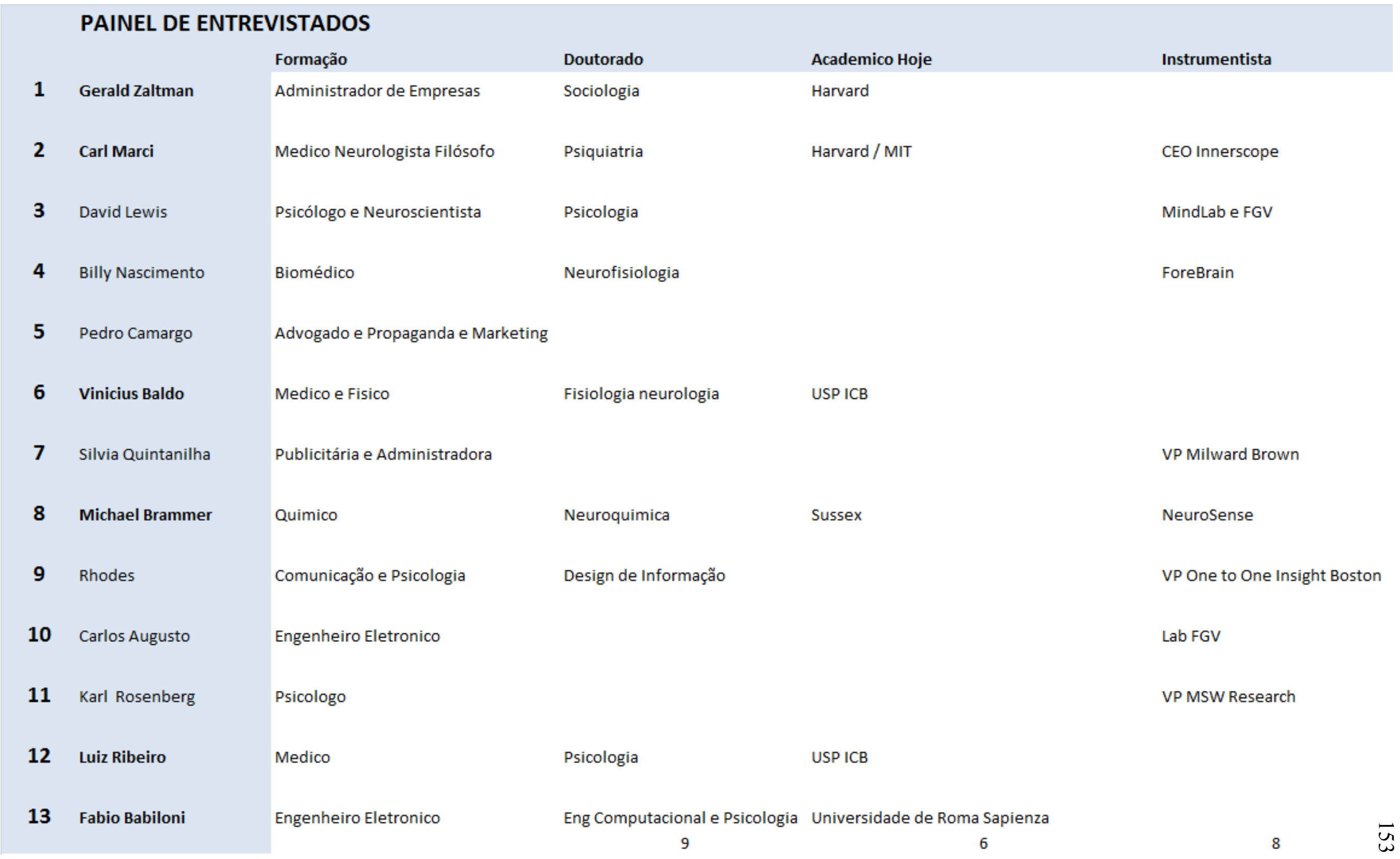




\begin{tabular}{|c|c|c|c|c|c|}
\hline & \multicolumn{4}{|c|}{ Envolvimento com Comportamento } & \multirow[b]{2}{*}{ Técnicas } \\
\hline & & & Neurosciencia & & \\
\hline 1 & Gerald Zaltman & base & propaganda & Base & Imagem \\
\hline 2 & Carl Marci & aprofundar & Depressão e negociação & Doença & biometria \\
\hline 3 & David Lewis & aprofundar & stress de guerra & Doença & biometria e EEG \\
\hline 4 & Billy Nascimento & aprofundar & comp emocional / visão & Base & biometria \\
\hline 5 & Pedro Camargo & curiosidade & leituras & Comportamento & \\
\hline 6 & Vinicius Baldo & aprofundar & tempo de reação & Base & EEG + biometria \\
\hline 7 & Silvia Quintanilha & base & na empresa & Comportamento & biometria e EEG \\
\hline 8 & Michael Brammer & base : cerebro humano para reação & imagem cerebro & Base & imagem \\
\hline 9 & Rhodes & base & usabilidade & Comportamento & biometria \\
\hline 10 & Carlos Augusto & base & na empresa & Comportamento & EEG e biometria \\
\hline 11 & Karl Rosenberg & aprofundar & propaganda & Comportamento & EEG e biometria \\
\hline 12 & Luiz Ribeiro & aprofundar & tempo de reação & Base & biometria \\
\hline 13 & Fabio Babiloni & aprofundar & EEG hightec & Base & EEG \\
\hline
\end{tabular}


APÊNDICE 3

\section{Neuromarketing: Definição}

não gosta do termo

aplicação dos conhecimentos/tecnicas da neurosciencia

entender o implicito /não cognitivo

1

4

5

6

7

9

10

11

12

13

Total

academicos
1

1

1

1

1

9 
APÊNDICE 4

Neuromarketing: $O$ que dá para medir e exemplos

sentimento + ou - Intensidade da Reação respostas inconscientes estados mentais

resp atitudinais/tomada decisão

1

2

3

4

5

6

7

8

9

10

11

12

13

Total

academico
1

1

1

1

1

1

2

1
2
3

3 
APÊNDICE 5

\section{Neuromarketing: o que se mede em marketing}

Marca Ideia

Prototipo/Design Propaganda Impresso

Musica/Jingle Ponto de Venda Loja Virtual Fragrancia/Sensação Preço

Web/Navegação/Jogos Emoção/Conexão/Decisão

1

2

1

1

1

1

1

1

3

$4 \quad 1$

1

1

$5 \quad 1$

6

7

1

1

1

1

1

1

8

1

1

9

1

1

1

1

1

1

10

$11 \quad 1$

13 Total

$\% \quad 3 \%$

academico

$23 \% \quad 38 \%$

$\begin{array}{cc}5 & 6 \\ 38 \% & 46 \% \\ 1 & 1\end{array}$

$\begin{array}{ccc}1 & & \\ 8 & 5 & 2 \\ 62 \% & 38 \% & 15 \% \\ 3 & 1 & 0\end{array}$

3
$23 \%$
0

6
$46 \%$
2

2
$15 \%$
2

1
$8 \%$
0
6
$46 \%$

3 


\section{Neuromarketing: tecnicas que utiliza}

Biometria/psicometria eye tracking

1

2

3

4

5

6

7

8

9

10

11

12

13

Total

$\%$ do total

icademico

10
$+2$

1

1

1

12
$92 \%$
5

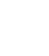

1

\section{1}

1

1

$\begin{array}{ccccc}11 & 8 & 1 & 4 & 1 \\ 85 \% & 62 \% & 8 \% & 31 \% & 8 \% \\ 5 & 3 & 0 & 1 & 0\end{array}$


APÊNDICE 7

\section{Neuromarketing: Vantagens}

Resp inconscientes/Diminuição de incertezas Complementação de outros dados

Acionar emoções

Criar estimulo/experiencia/Dosarcampanha

Metodo cientifico

Multidisciplinaridade

Diminuição de custo de pesquisas

1

2

7

9

10

11

12

13

Total

Academicos
1

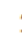

1

5

0,00

1
$8 \%$

0,00 
APÊNDICE 8

Neuromarketing: Limitaçôes

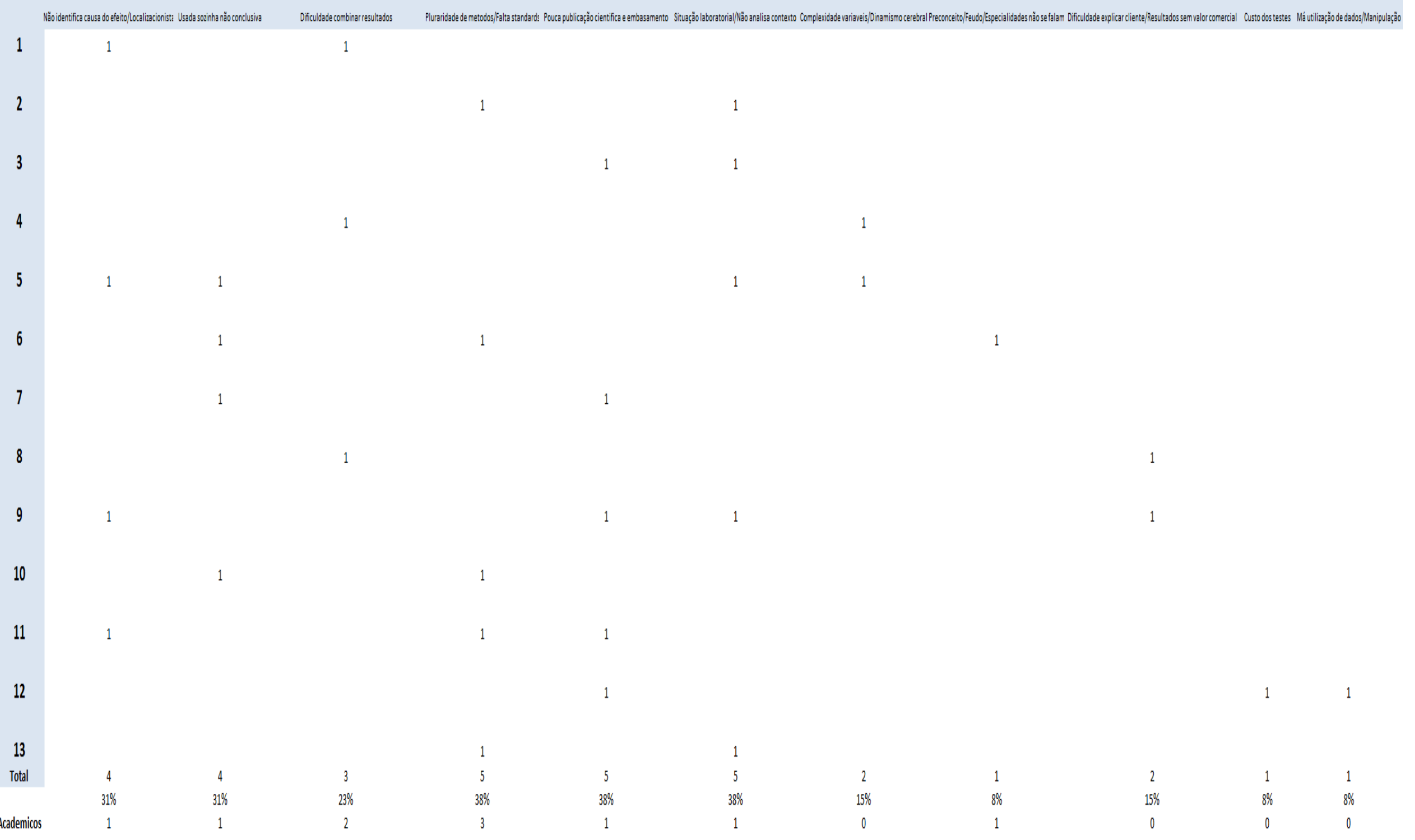




\section{APÊNDICE 9}

\section{Neuromarketing: Preocupações}

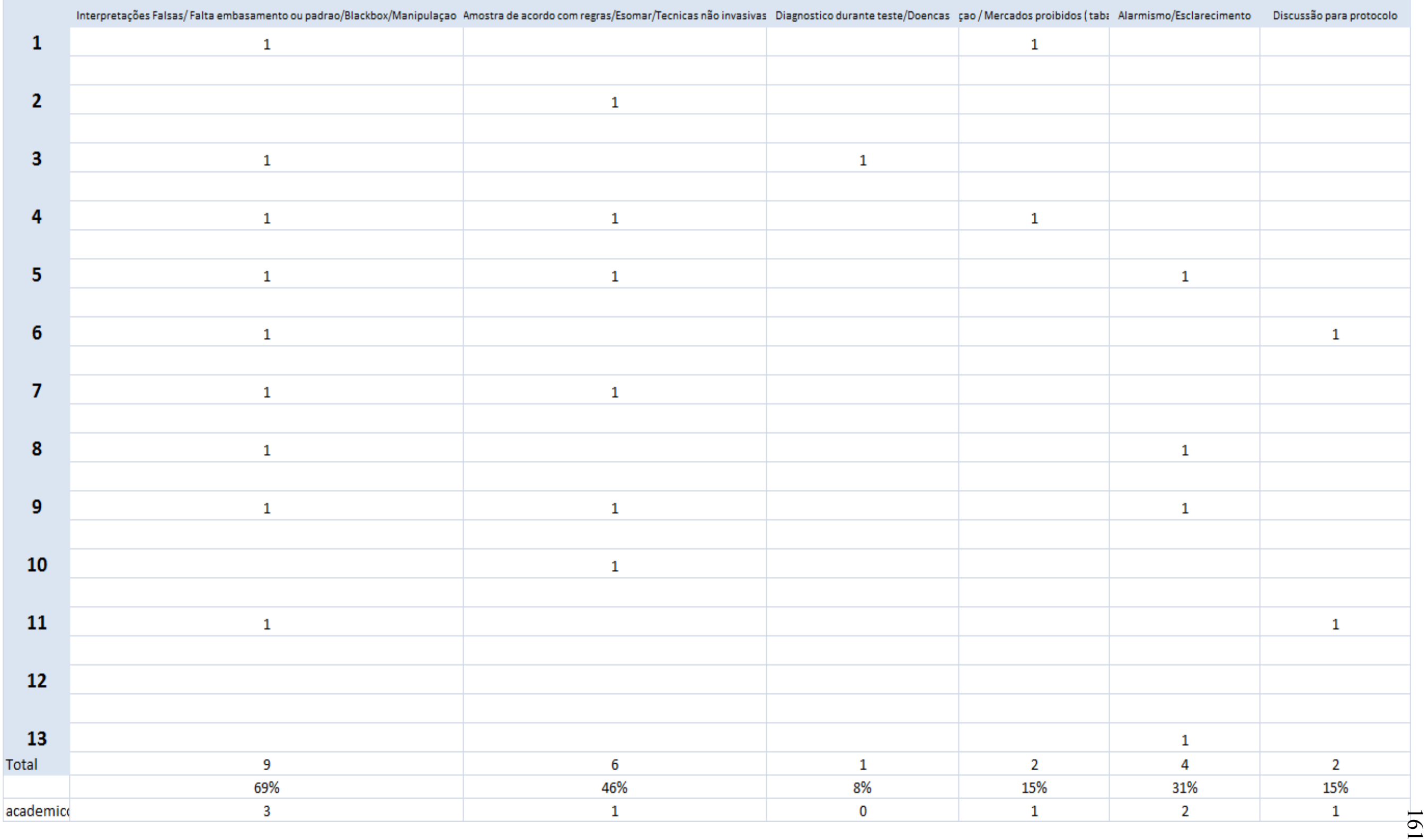


APÊNDICE 10

\section{Neuromarketing: 0 futuro}

\begin{tabular}{|c|c|c|c|c|c|c|c|c|}
\hline \multirow[b]{2}{*}{1} & Combinação metodos/ Novas areas & Genetica & Endocrinologia & Psicologia/Medicina & Eletrofisiologia & Portabilidade/Wireless/Nida real & e de combinação e Modelos / Diagnostico e interp & Entender o sensoria \\
\hline & 1 & & & & & & & \\
\hline & & & & & & & & \\
\hline \multicolumn{9}{|l|}{2} \\
\hline & & & & & & & & \\
\hline \multicolumn{9}{|l|}{3} \\
\hline & & & & & & & & \\
\hline \multicolumn{9}{|l|}{4} \\
\hline & & & & & & & & \\
\hline 5 & 1 & 1 & 1 & & & & & \\
\hline & & & & & & & & \\
\hline 6 & 1 & & & & 1 & 1 & 1 & \\
\hline \multirow{3}{*}{7} & & & & & & & & \\
\hline & & & & & & & & 1 \\
\hline & & & & & & & & \\
\hline \multirow[t]{2}{*}{8} & & & & & & 1 & 1 & \\
\hline & & & & & & & & \\
\hline \multirow[t]{2}{*}{9} & & & & & & & 1 & \\
\hline & & & & & & & & \\
\hline \multirow{2}{*}{10} & 1 & & 1 & & & & & \\
\hline & & & & & & & & \\
\hline \multirow[t]{2}{*}{11} & & & & & & & 1 & \\
\hline & & & & & & & & \\
\hline \multirow[t]{2}{*}{12} & 1 & & & 1 & & & & \\
\hline & & & & & & & & \\
\hline 13 & 1 & & & 1 & & 1 & & \\
\hline \multirow[t]{2}{*}{ Total } & 6 & 1 & 2 & 2 & 1 & 3 & 4 & 1 \\
\hline & $46 \%$ & $8 \%$ & $15 \%$ & $15 \%$ & $8 \%$ & $23 \%$ & $31 \%$ & $8 \%$ \\
\hline ademico & 4 & 0 & 0 & 2 & 1 & 3 & 2 & 0 \\
\hline
\end{tabular}


APÊNDICE 11

Neuromarketing: Fontes

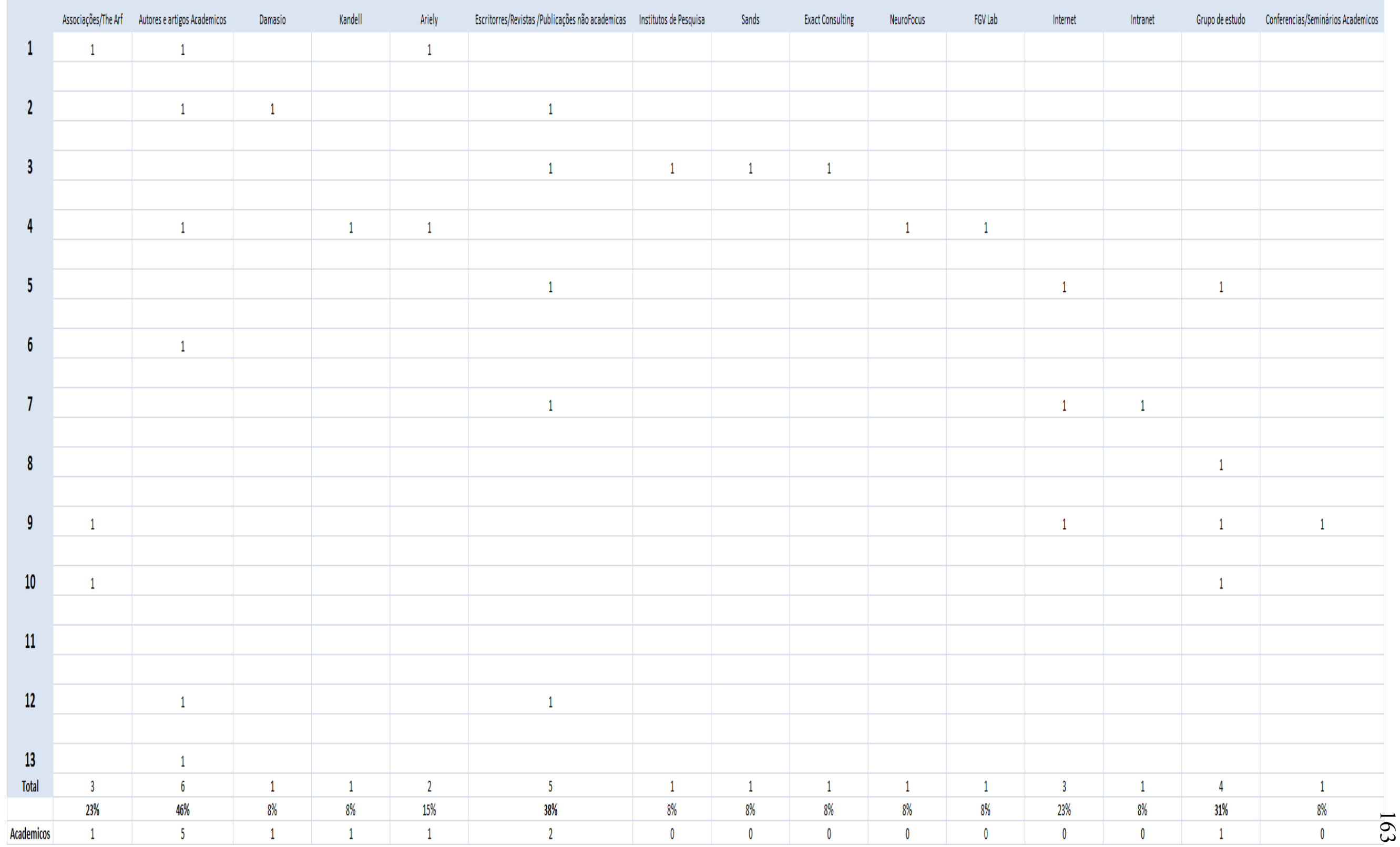




\section{Neuromarketing: Resumo 10 Categorias}

\section{Envolvimento com Comportamento}

2 Razões para estudar

3 Envolvimento com Neurosciencia e tecnicas familiares

4 Definição Neuromarketing possiveis medidas

5 Fases possiveis em Marketing

6 Tecnicas utilizadas

7 Vantagens e Limitações

8 Preocupações

9 Futuro

10 Fontes de Informações
Aprofundar é a maior menção da amostra

Entendimento maior do comportamento foi o item mais respondido

Aprofundar entendimento, utilizando biometria ( instrumentistas) ou imagem ( academicos)

Uma aplicação da neurosciencia no marketing para medir intensidade e respostas a estimulos

A maioria definiu análise de comunicação, protótipo e navegação, seja por loja virtual ou site

Biometria e Eletroencefalo são as mais utilizadas, com destaque para eye tracking

Vantagens: Diminuição das incertezas e complementação das informaçoes são as mais mencionadas Limitaçốes: mediçôes ainda são laboratoriais e há falta de material publicado sobre o tema A ma interpretação dos resultados é tido como a maior preocupação e a manipulação dos resultados como consequencia do ato.

Busca de uma maior combinação de areas cientificas para melhorar os estudos é esperada Fontes acadêmicas e autores não acadêmicos. 